\title{
A TERRORIZMUS HATÁSAI ÉS MEGJELENÉSE A DEMOKRATIKUS JOGRENDBEN
}

\author{
Doktori értekezés
}

Sabjanics István

Témavezető: Prof. Dr. Varga Zs. András

Pázmány Péter Katolikus Egyetem

Jog- és Államtudományi Doktori Iskola

Budapest, 2019

(Kézirat lezárva: 2019. 11. 20.) 


\section{TARTALOMJEGYZÉK}

Köszönetnyilvánítás.

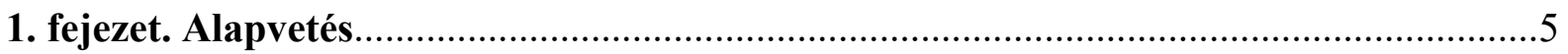

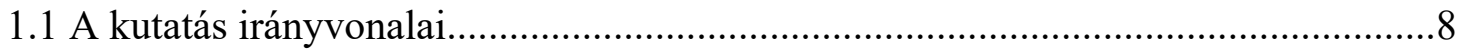

1.1.1 A terrorizmus és a háborús retorika.....................................................11

1.1.2 Terrorellenesség és a fokozatosság..................................................15

1.1.3 A terrorveszély nemzetközi exportja................................................19

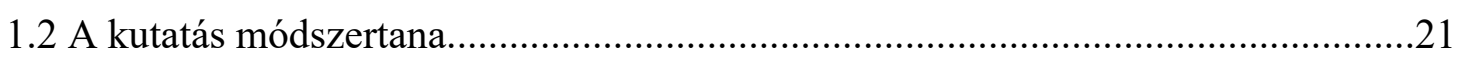

1.3 A terrorizmusra vonatkozó szabályok megjelenése a jogrendszerekben.................25

1.4 A demokrácia, valamint a szubsztantív és a procedurális demokrácia....................28

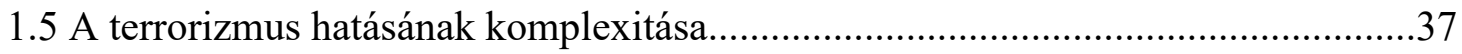

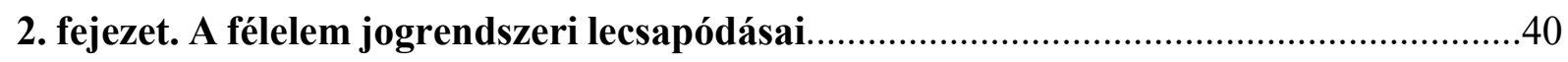

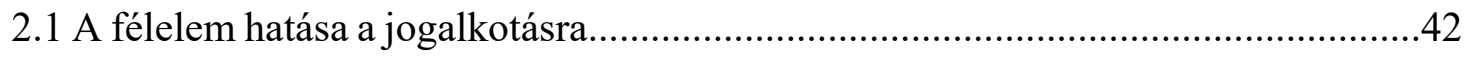

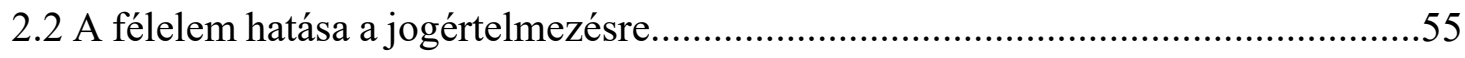

2.3 A félelem hatása a nemzetközi kapcsolatokra.........................................................60

2.3.1 A félelem belső eredetü hatásai a nemzetközi kapcsolatokra....................62

2.3.2 A félelem külső eredetủ hatásai a nemzetközi kapcsolatokra

- a közös kulturális alapok..........................................................................64

2.3.3 A félelem külső eredetü hatásai a nemzetközi kapcsolatokra

- az empátia.

2.3.4 A félelem külső eredetü hatásai a nemzetközi kapcsolatokra

- a politikai szövetség. .68

2.3.5 A félelem külső eredetü hatásai a nemzetközi kapcsolatokra

- a katonai szövetség. .69

2.4 Megállapítások a félelem jogrendszeri hatásairól . .71 


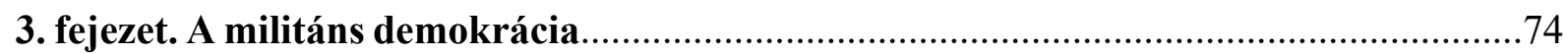

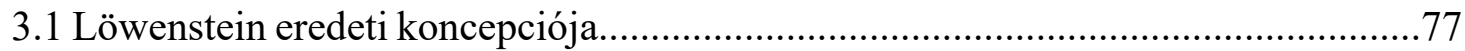

3.2 A militáns demokrácia jelentésének pluralizálódása............................................83

3.3 A militáns demokrácia 20. századi alkalmazásának gyakorlata.............................93

3.4 A militáns demokrácia 21. századi alkalmazásának gyakorlata.............................99

3.5 A militáns demokrácia és a nemzetközi terrorizmus összefüggései.......................102

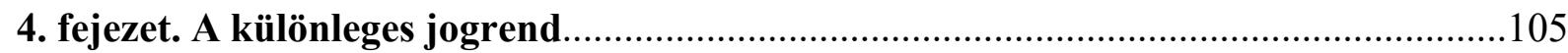

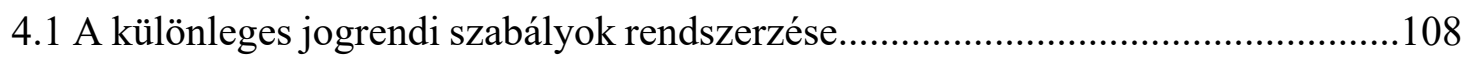

4.2 Franciaország 2015-2017 között bevezetett különleges jogrendje és hatásai..........114

4.2.1 Különleges jogrend a francia jogrendszerben.......................................116

4.2.2 A 2017. október 30-án elfogadott 2017-1510. számú törvény.................118

4.3 Magyarország Alaptörvényének hatodik módosítása..........................................132

4.4 A terrorizmus és a különleges jogrend kapcsolatának összefüggései....................136

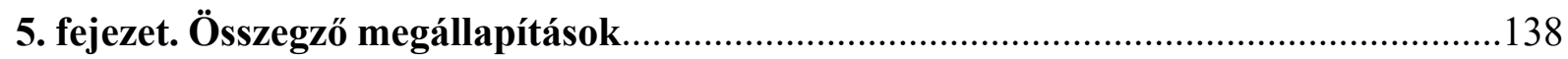

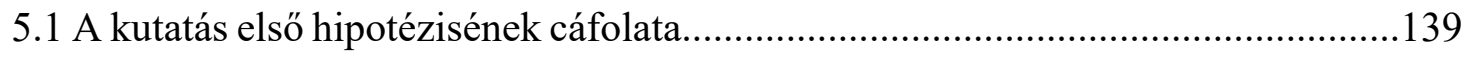

5.2 A kutatás második hipotézisének igazolása...................................................... 142

5.3 A kutatás harmadik hipotézisének igazolása................................................... 145

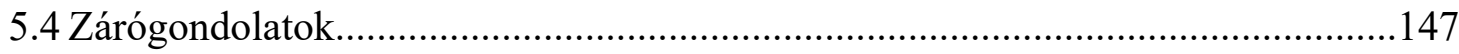

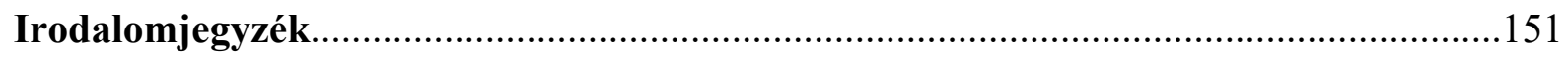

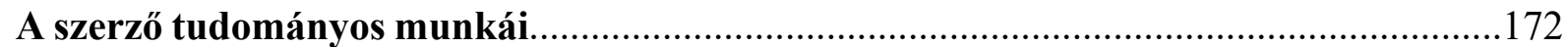




\section{KÖSZÖNETNYILVÁNÍTÁS}

Köszönettel tartozom Varga Zs. András professzor úrnak, amiért látta bennem és a választott kutatási témámban a fantáziát, amikor elvállalta a témavezetést. Köszönet illeti a töretlen bizalomért, a témavezetői és atyai jótanácsaiért.

Hálával tartozom néhai Kilényi Géza professzor úrnak, amiért annak idején doktoranduszként magához vett és megtanított arra, hogy makacsul kell ragaszkodni az objektivitáshoz egy kutatómunka során.

Hálával tartozom továbbá néhai Lábady Tamás professzor úrnak, akitől megtanulhattam, hogy a jog nem pusztán strukturált gépszöveg, hanem jó és célravezető, ha a jogászi münyelv szépségét meglátjuk és szépirodalmi minőségü alkalmazásával teremtünk értéket.

Köszönöm Hajas Barnabásnak, hogy másodéves jogász hallgató koromban bíztatott az OTDK$\mathrm{n}$ való elindulásra és ezzel segített kinyitni a tudományos pályára nyíló ajtót.

Köszönöm Ádány Tamásnak, Csink Lórántnak és Gerencsér Balázsnak a kutatás során adott jó tanácsaikat és inspiráló meglátásaikat.

Köszönöm nagyszüleimnek és szüleimnek a támogatást és a biztos családi hátteret.

Különösen Nagyanyámnak, aki felnevelt és megtanított arra, hogy a szeretet, az alázat és a kitartás olyan erények, amelyek, ha tudatosan törekszünk rá, végigkísérik és segítik az embert egész életén át.

Köszönöm Édesapámnak, aki példamutatásával megtanított arra, hogy mindig lehet és érdemes felállni és újrakezdeni, és arra, hogy a tudomány kikezdhetetlensége mindig biztos támaszt nyújt.

Végül legföképpen feleségemnek és gyermekeimnek köszönöm azt a szeretetet és megértést, amely biztos hátteret jelentett a kutatás egésze alatt, amely nélkül biztosan nem értem volna célt, és amelynek kézzelfogható eredményét most bemutathatom. 


\section{ALAPVETÉS}

A terrorizmus napjaink egyik legmeghatározóbb témája, amely egy-egy terrortámadást követően egyértelmüen dominálja a közbeszédet. Meghatározó az állam és a társadalom számára, hiszen az állam megfelelő szerveket hoz létre a veszély elhárítására, a kárenyhítésre, a lakosság felkészítésére, hogy egy veszélyes szituációban hogyan cselekedjen, illetve a gyanús viselkedést jelentse. Ezért a terrorizmus - a szó eredeti jelentéséből kiindulva - a rémületen kívül nem szabadna, hogy komolyabb kihívást jelentsen. A terrorveszély politikai és szakmai interpretációja $^{1}$ szerint a jogrendszerben megtalálhatók a megfelelő válaszok, az állami szervezetrendszer és az igazságszolgáltatás felkészült és alkalmas arra, hogy a terrorizmus jelenségére (is) adekvát választ adjon. A terrorizmusra a jogrendszernek jelen formájában is választ kell tudnia adni. Azt, hogy az állami szervezetrendszer és végső soron a jogrendszer képes a terrorizmus kezelésére, az egy premissza, amelyet kiindulópontként el kell fogadnunk annak érdekében, hogy a terrorizmus kihívására jogállami választ tudjunk adni. A terrorizmus és az erőszak jelentette anarchia nem lehet a társadalmi stabilitást, fejlődést és biztonságot jelentő demokratikus jogállam alternatívája. A terrorizmus, akár megvalósul, akár sikerül megakadályozni, hatást gyakorol arra az állami szervezetrendszerre és jogrendszerre, amellyel kapcsolatba kerül. Ezek a hatások lehetnek átmenetiek, rövid távon vagy hosszú távon érvényesülők. A közvetlen szakmai kérdések (felderítés, adat- és információgyüjtés, elemzőértékelő munka) mellett, lényeges a terrorizmussal összefüggő ítélkezési gyakorlat ${ }^{2}$ és akár a terrorizmussal kapcsolatos közbeszédben felmerülő diszkrimináció is. ${ }^{3}$ Mennyire érvényesül

\footnotetext{
${ }^{1}$ A 9/11-es támadást követő politikailag és katonailag is rendkívül mozgalmas időszakában született William, CrotTy (ed.): The Politics of Terror. The U.S. Response to 9/11. Northeastern University Press, 2004 (a továbbiakban: CROTTY) pp. ix-xiii.; a későbbi időszakban már megjelentek a terrorellenes nemzetközi jellemzően észak-atlanti - küzdelemnek az európai interpretációi is, amelyeket jól összefoglalja Christian, KAUNERT, Sarah, LÉONARD: The collective securitisation of Terrorism in the European Union. In: West European Politics. 2018/2. pp. 261-277.

${ }^{2}$ Szemléltető az Emberi Jogok Európai Bíróságának (EJEB) gyakorlata a terrorizmussal összefüggésben a nemzeti fórumok előtt született döntések megítélését illetően. Különösen az 1961-ben született Lawless v. Írország http://hudoc.echr.coe.int/eng?i=001-57518 (letöltés dátuma: 2019. 09. 29.) és a nemzetközi terrorizmus elterjedését követően született ítéletek közül leginkább a 2009-es A. és mások v. Egyesült Királyság http://hudoc.echr.coe.int/eng-press?i=003-2638619-2883392 (letöltés dátuma: 2019. 09. 29.) döntés indokolását olvasva szembetűnő, hogy míg 1961-ben a jogkérdés az volt, hogy bírósági tárgyalás nélkül fogva tartható-e a terrorizmus feltételezett elkövetője néhány hónapig (1957. július-december), addig a „,modern” jogi értékelés már inkább arra fókuszált, hogy milyen fórumhoz fellebbezhet egy terrorizmussal vádolt személy az őt elmarasztaló döntés ellen. A többi hasonló ügy megtalálható az EJEB tárgyban készített összefoglalójában https://www.echr.coe.int/Documents/FS Terrorism ENG.pdf. (letöltés dátuma: 2019. 09. 29.)

3 Privacy International report on Discrimination and Anti-TerrorPolicy Across Europe. 2005 szeptember https://webcache.googleusercontent.com/search?q=cache:6JP4I0CN20YJ:https://privacyinternational.org/sites/d efault/files/2017-12/Discrimination\%2520and\%2520Anti-
} 
például a média és a társadalom diszkriminációja egy fehér ember által elkövetett több ember halálát okozó cselekmény és egy muszlim által elkövetett azonos cselekmény értékelésekor? ${ }^{4}$ Előbbi esetében az első kérdések között rendszerint azt találgatják, hogy vajon szenvedett-e mentális zavarban, míg utóbbi esetében a terrorszervezethez való kötődést vizsgálják rögtön. ${ }^{5}$ A terrorizmus elleni küzdelem politikai, jogi vagy szakmai megfontolásairól már számos tudományos írás született. Jelen doktori értekezés célja, hogy a terrorizmus egyes látens hatásaira irányítsa rá a figyelmet.

A kutatás eredményeinek bemutatásakor azért döntöttem a spirális gondolatmenet mellett, mert meggyőződésem, hogy a témakör komplexitása és a kutatás célja csak így érhető el. Számtalan kutatás született már arról, hogy a terrorizmus miként alakítja 21. századi életünket, azonban ezek - tudományterületi vagy megvalósíthatósági szempontok miatt - egy-egy konkrét kérdéskörre összpontosítottak. Egyebek mellett szóba került már a terrorizmus elkövetőinek felelősségre vonása, ${ }^{6}$ a mögöttes állami felelősség megállapíthatósága, ${ }^{7}$ finanszírozásának, ${ }^{8}$ megelőzésének, ${ }^{9}$ és gazdasági hatásainak ${ }^{10}$ a kutathatósága. A kutatás célja, hogy a terrorizmus (köz)jogi megközelítésének és kezelésének 21. századi problematikáját bemutassa. A 2001. szeptember 11-én elkövetett terrortámadást úgy szokták bemutatni, mint amely megváltoztatta a demokratikus társadalmak hozzáállását a terrorizmushoz. Rávilágított arra, hogy még a legnagyobb költségvetéssel rendelkező nemzetbiztonsági és rendvédelmi rendszer is kijátszható. Végső soron pedig erre vezethető vissza, hogy viszonylag rezignáltan kezeljük a magánszféra korábban abszolútnak tekintett, ma mégis inkább relatív jellegét. A problémakör alapja azonban, hogy a korábbi tapasztalatok alapján, vagyis a 20. században kidolgozott

Terror\%2520Policy\%2520Across\%2520Europe 1. pdf $+\& c d=1 \&$ hl=hu\&ct=clnk\&gl=hu\&client=safari $\quad$ (letöltés dátuma: 2019. 09. 29.)

${ }^{4}$ Gunn Elisabeth, Birkelund, Tak Wing, Chan, Elisabeth, Ugreninov, Arnfinn H., MidtBøen, Jon, Rogstad: Do terrorist attacks affect ethnic discrimination in the labour market? Evidence from two randomized field experiments. In: The British Journal of Sociology2019/1., pp. 241-260.

5 https://www.justsecurity.org/63499/how-news-media-talk-about-terrorism-what-the-evidence-shows/ (letöltés dátuma: 2019. 09. 29.)

${ }^{6}$ Ronald, Dworkin: Terror \& the Attack on Civil Liberties. In: The New York Review of Books. 2003/17., https://www.nybooks.com/articles/2003/11/06/terror-the-attack-on-civil-liberties/ (letöltés dátuma: 2019. 09. 29.)

${ }^{7}$ Tal, BECKER: Terrorism and the State: Rethinking the Rules of State Responsibility. Hart Publishing, 2006., p. 390.

${ }^{8}$ BARTKÓ Róbert: A terrorizmus elleni küzdelem kriminálpolitikai kérdései. Universitas-Györ, 2011. VASS György: A terrorizmus finanszírozása elleni küzdelem nemzetközi aspektusai. Doktori értekezés. 2017.

9 Annemarie, VAN DE WeERT, Quirin A. M., EIJKMAN: Subjectivity in detection of radicalisation and violent extremism: a youth worker's perspective. In: Behavioral Sciences of Terrorism and Political Aggression. 2019/3., pp. 191-214.

${ }^{10}$ David Mc. A., BAKER: The Effects of Terrorism on the Travel and Tourism Industry. In: International Journal of Religous Tourism and Pilgrimage. 2014/1., pp. 58-67. 
elméleti keretekben gondolkozunk. Mindeközben a jelenség, ${ }^{11}$ a társadalom, a politikai közeg és persze a minket körülvevő technológia nagyon is 21 . századi.

${ }^{11}$ Az ún. új típusú terrorizmusról ld. bővebben TÁLAS Péter (szerk.): A terrorizmus anatómiája. Zrínyi Kiadó, Budapest, 2006. (a továbbiakban: TÁLAS 2006), p. 5. 


\subsection{A kutatás irányvonalai}

A kutatás három jelenségre fókuszál, amelyek úgy tünnek, hogy a jogi valóság részévé váltak az elmúlt két évtizedben. Az első, és egy pusztító terrortámadást követően rendszerint újra napirendre kerülő elképzelés szerint a terrorizmus elleni küzdelem valójában nem más, mint egy háború. Egy olyan sajátos nemzetközi fegyveres konfliktus, amelyben legtöbb esetben csupán az egyik oldalon találunk nemzetközi jogalanyisággal rendelkező feleket. Továbbá, a háborút nem zárta le ezidáig békeszerződés, de valójában a tüzszüneti megállapodás megkötésének is kérdéses az elvi lehetősége. Hiszen a konfliktus terrorista oldalának tekintett szereplői nem állandó entitások, vagyis a terrorizmus ellen háborút folytató (nyugati) állam hiába neutralizálja ${ }^{12}$ ellenségét, annak helyébe más lép(het), illetve a Bush-doktrína alapján, a jogalapot valójában egy végrehajtói döntés (executive decision) jelenti. Egy szervezetnek a terrorista minőségét, illetve ennek a szervezetnek a harmadik állam általi befogadását és a támogatását egyoldalúan és megfellebbezhetetlen módon állapította meg az Egyesült Államok kormánya.

A háborús retorika egyébként érdekes, de vélhetően nem véletlen módon párhuzamba állítható az iszlámban előírt dzsihád ${ }^{13}$ egyfajta félremagyarázásával és időnként még a keresztes háborúk romantikája is előkerül. ${ }^{14}$ A 9/11-es terrortámadást követően megfogalmazott Bush-doktrína ${ }^{15}$ szerint az Egyesült Államoknak jogában áll azon államokkal szemben akár katonai erővel is fellépni, amelyek terrorista csoportokat befogadnak vagy támogatnak. A Bush doktrína azonban nem több, mint egy külpolitikai irányvonal, amely meghatározta az Egyesült Államok 2001-2008 közötti kül- és biztonságpolitikai megfontolásait. Az ún. afganisztáni háborút az Egyesült Államok 2001. október 7-én indította el, amikor kevesebb, mint egy hónappal a 9/11es terrortámadást követően katonailag megszállta a tálib rezsim uralta Afganisztánt.

\footnotetext{
${ }^{12}$ Ez jelenthet fizikai vagy operatív megsemmisítést, esetleg békekötést, ahogyan azt láttuk a palesztin Fatah esetében.

${ }^{13}$ A fogalom jelentése valójában: Isten útján küzdelem, törekvés. (Korán 9:24)

14 Legelőször maga George W. Bush elnök beszélt nyilatkozatában a 9/11-es merénylet utáni első sajtótájékoztatójában arról, hogy a terrorizmus elleni küzdelmet keresztesháborúként fogja fel [This crusade, this war on terrorism is going to take a while. And the American people must be patient. https://georgewbushwhitehouse.archives.gov/news/releases/2001/09/20010916-2.html] (letöltés dátuma: 2019. 09. 29.); később aztán a köztudatban Alexander, COCKBURN fordulata ragadt meg, miszerint az afganisztáni háború a 10. keresztesháború https://www.counterpunch.org/2002/09/07/the-tenth-crusade/ (letöltés dátuma: 2019. 09. 29.)

${ }_{15}$ Kritikájára lásd bővebben Neta C., CRAWFORD: Just War and the U.S. Counterterror War. In: Perspectives on Politics.2003/1., pp. 5-25.
} 
A terrorizmus elleni küzdelemmel kapcsolatosan az elmúlt évtizedek alatt kialakult egy másik köztudatban élő vélemény, miszerint a terrorizmussal kapcsolatos állami fellépések aránytalanok és az alkalmazott intézkedések közötti fokozatosság eltünt. Erre legtöbbször a hírhedt U.S.A.P.A.T.R.I.O.T. Act hirtelen elfogadott ${ }^{16}$ jogi túlkapásait szokták felhozni, de mellette más államok terrorizmusra reflektáló jogalkotását is vádolták már aránytalansággal. ${ }^{17}$ A fokozatosság, vagy másként az arányosság megtartása persze nem teljesen egyértelmü elvárásként fogalmazódik meg, amikor egy-egy terrorellenes intézkedés vagy jogszabálymódosítás kritikájaként jelenik meg. Annak érdekében tehát, hogy a fokozatosság és a terrorellenesség ne oximoronként mutassanak egymás mellett, néhány alapvető kérdést szükséges tisztázni.

Az egyik ilyen kérdés, hogy a terrorizmus jelentette veszélyhelyzet objektív felmérésére melyik szerv képes, illetve mennyire esik egybe vagy éppen távol ettől a szervtől az a döntéshozó, amelynek jogköre van mérlegelni a terrorizmusra adandó állami válaszokat. Minél messzebb esik a két szerv egymástól, vagy egyéb okból lassabb, esetleg szürt az információáramlás, annál nagyobb eséllyel nem fog megfelelni a döntéshozó lépése az arányossági követelményeknek. Ebben persze szerepe van az időtényezőnek is, hiszen a megkésett vagy elhamarkodott döntés sem lesz arányos. További kérdés, hogy a döntéshozó rendszerint politikai jellegére tekintettel, milyen mértékben kénytelen figyelembe venni az ún. közakaratot. Ahogyan azt a U.S.A.P.A.T.R.I.O.T. Act kapcsán láthattuk: hiába utasította el rendre a Kongresszus a korábbi Bush és Clinton adminisztrációk által javasolt, terroristák megfigyelésére szolgáló lazább lehallgatási és megfigyelési szabályokat. A 9/11-es merénylet utáni sok milliós felháborodott választó akkora politikai nyomást jelentett a képviselők számára, hogy nem láttak lehetőséget az érdemi vitára. ${ }^{18}$

A kutatás során vizsgált harmadik jelenség kevésbé egzakt. A nemzetközi terrorizmus vonatkozásában, főleg az utóbbi 20 évben, egy-egy terrorellenes intézkedés, jogalkotás vagy leggyakrabban retorika többször megjelent harmadik államok életében. Mindezt oly’ módon, hogy a szükséges jogi indokolás, a politikai, szociológiai vagy gazdasági megfontolások szinte

\footnotetext{
${ }^{16}$ A törvényt 2001. október 26-án fogadták el, amely a kétpárti támogatottság mellett is kifejezetten gyors eljárásnak tekinthető. Összehasonlításképpen ld. https://www.govtrack.us/congress/bills/statistics (letöltés dátuma: 2019. 09. 29.)

17 Gondoljunk csak az Egyesült Királyság számtalan terrorizmussal összefüggésben hozott törvényére, Franciaország 2017-1510. számú törvényére, vagy éppen Magyarország Alaptörvényének hatodik módosítására.

${ }^{18}$ Ezt jól mutatja, hogy enyhe kritika megfogalmazására is csak a későbbiekben és első sorban konkrét túlkapások fényében, a Patriot Act által megteremtett légkört az 1950-es évek hírhedt mccarthyzmusához hasonlítva.
} 
elkerülhetetlenné tették azt a döntés, amely történetesen sokban hasonlít mások gyakorlatára. Vélhetően mindez nem puszta véletlen, hanem tudatosság határozza meg a döntéshozók motivációját. Ezt a motivációt azonosítom a félelemmel, amely azonban távol áll attól, hogy kizárólagosan érvényesüljön, a viszonyítást segítő absztrakció céljának viszont megfelel. A feltételezés tehát az, hogy a közel azonos időben, azonos célból és nagyjából megegyező tartalommal (eszközrendszerrel, eljárásokkal és főként retorikai fordulatokkal) született intézkedések és a vonatkozó elvégzett jogalkotás között, az egyértelmü jogrendszeri különbségek ellenére szoros összefüggés van. Ezt az összefüggést nem csak felismerni szükséges, de mindezek fényében célszerü elvégezni a döntéshozó konkrét terrorellenes lépésének ex post facto értékelését.

A téma természetéből fakadóan kézenfekvő a terrorveszély növekedésével párhuzamosan korlátozott alapjogok vizsgálata. A kutatás célkitüzései szándékosan nem helyezik a hangsúlyt az alapjogi kérdésekre, amelynek több oka van. Egyfelől, a biztonság vagy szabadság klasszikus, de véleményem szerint finoman szólva is pontatlan szembeállítása egymással, nem segíti, hanem akadályozza a válaszkeresést. A kérdést akár hamis vitafelvetésnek is tekinthetnénk, hiszen a biztonságnak és szabadságnak egyidejüleg kell érvényesülnie, különkülön ugyanis nincs értelme. A kettő közötti kapcsolat sokkal összetettebb annál, minthogy a problémafelvetés letudható volna egy egyszerű és kizárólagos értékválasztással. A szabadságnak előfeltétele a biztonság, míg a biztonságnak csak szabadság mellett adhatunk értelmezhető keretet, amely lényegében megkülönbözteti a börtönrácsok egyik oldalát a másiktól. Az alapjogi kérdésekkel lépten-nyomon találkozhatunk, ha a terrorizmus jogrendszeri hatásait vizsgáljuk. Nem véletlenül számít igen népszerü kutatási témának. Jelen kutatás ugyanakkor kifejezetten és szándékoltan csupán járulékosan, a hipotézisek vizsgálata során magyarázó jelleggel emeli be a szükséges mértékben az alapjogi kérdéseket. Ezzel természetesen nem az alapjogi megfontolások fontosságát vitatom, pusztán teret engedek a kutatási hipotézisek igazolását vagy cáfolását alátámasztó szempontoknak. 


\subsubsection{Első hipotézis: A terrorellenes intézkedések látens módon produkálják egy fegyveres konfliktus belső jogrendszeri hatásait.}

A terrorizmus ellen folytatott nemzetközi katonai fellépés nem egyenlö a nemzetközi jogi értelemben vett nemzetközi fegyveres konfliktussal. A nemzetközi fegyveres konfliktusokra irányadó nemzetközi jogi normák és a szokásjog ennek a lehetőségét egyértelmủen kizárja. A kutatás szempontjából ezért nem azt a kérdést teszem fel, hogy a nemzetközi terrorizmus elleni fellépés azonosítható-e a nemzetközi fegyveres konfliktussal? A kutatás során vizsgált kérdés ennek megfelelően az, hogy a nemzetközi terrorizmus elleni fellépés ugyanazokat a belső jogi hatásokat fejtik-e ki, mint egy valódi nemzetközi fegyveres konfliktus? Vajon hasonló jelenségek fordulnak-e elő egy terrortámadást követően egy állam jogrendszerében, illetve hogyan reagál arra a jogalkotó és a joggyakorlat, ha elhúzódó terrorellenes „harcokat” folytat az állam?

Maga a kifejezés: terrorellenes harcok vagy még inkább háború, erősen vitatható megfogalmazás. ${ }^{19}$ A háború ugyanis tradicionális értelemben véve a legalább két állam között zajló nemzetközi fegyveres konfliktus, amelyre egy több száz éves kimunkált szabályrendszer vonatkozik, több ezer évre visszanyúló szokásjogi gyökerekkel. Mások mellett ezt vitatta Alain Pellett $^{20}$ és Ackerman, ${ }^{21}$ akik szerint eleve elhibázott lépés a nemzetközi fegyveres konfliktusokra való hivatkozás egy olyan küzdelemben, amelyben többnyire csupán az egyik fél lesz állami szereplő és nem is minden esetben tartozik a jogkérdés megítélése a nemzetközi jog hatálya alá. Arról már nem is beszélve, hogy a terrorizmus belső jogi megítélésében sem mutat egyértelmü képet a nemzetközi közösség. Európában a terrorizmus büntetőjogi megítélése az irányadó. Míg az Egyesült Államokban komoly tábora van annak az elméletnek, miszerint a terroristák nem élvezhetik a civil büntetőjog biztosította eljárásjogi garanciákat (pl.

\footnotetext{
${ }^{19}$ Az Egyesült Államok kormányzati (külpolitikai) narratívája a háború (war on terror) kifejezést, míg az európai kormányzati narratíva a küzdelem (struggle against terrorism) kifejezést használja. A háború kifejezés használata végletes, amely nem előnyös a politikában, ugyanakkor hazafias, amely viszont tömegeket képes mozgósítani. Mindazonáltal a küzdelem talán azért szerencsésebb, mert nem korlátozza az alkalmazható eszközöket és a kitüzhető célokat a katonai dimenzióra. Hiszen hazai bázison is rengeteget lehet és kell tenni a radikalizáció megelözése érdekében, amely viszont messze túl mutat a katonai fogalom- és eszköztáron.

${ }^{20}$ Alain, Pellett, Sarah, Pellett: The Aftermath of September 11. In: Tilburg Law Review. 2002/1., pp. 64-75.; elöször francia nyelven jelent meg Alain Pellett írása 2001. szeptember 17-én és november 15-én a Le Monde címü francia lapban. http://pellet.actu.com/wp-content/uploads/2015/12/PELLET-01-09-21-Le-Monde.pdf (letöltés dátuma: 2019. 09. 29.)

${ }^{21}$ Bruce ACKERMAN: This Is Not a War. In: The Yale Law Journal. 2004/8., pp. 1871-1907.
} 
nyilvános meghallgatás, esküdtszék), mert háborúban az ellenség katonáinak háborús büncselekményeit ( $\mathrm{ad}$ hoc) katonai törvényszékek bírálják el. ${ }^{22}$

A terrorizmus tradicionálisan a nemzeti büntetőjog szabályozási körébe tartozott. Mellette szólt a nyilvánvaló belpolitikai (az elkövetők jellemzően nemzetiségi és rendszerellenes, szélsőséges politikai kisebbségek voltak) okai mellett az is, hogy az elkövetök a megtámadott állam állampolgárságával rendelkeztek, illetve nem zajlott hagyományos értelemben vett háború. Vagyis nem volt olyan egyértelmü nemzetközi elem, ${ }^{23}$ amely indokolta volna a nemzetközi jog bevonását. A nemzetközi terrorizmus azonban megváltoztatta a mérlegelendő jogi körülményeket. A hagyományos (politikai) terrorizmus célpontválasztása kizárólagosan az állami intézményekre, azok fizikai jellegére (épületek), illetve megszemélyesítőjükre (hivatalos tisztséget ellátók: katonák, rendőrök, politikusok, bírák stb.) korlátozódott. A radikális iszlámista terrorizmus viszont a civil lakosságot is fenyegeti, $\mathrm{s}$ mivel így kevesebb kockázatvállalással nagyobb károkat okozhatnak, egyszerübbnek tünt a társadalmat is az állammal azonosítani. ${ }^{24} \mathrm{~A}$ terroristák által elkövetett cselekmények alakilag tehát hasonlóságot mutatnak a katonák által háborús körülmények között elkövetett, jellemzően a civil lakosság sérelmére elkövetett büncselekményekkel. ${ }^{25}$ Ezért felmerül a kérdés: a nyugati politikusok és a terroristák által hivatkozott háborús retorikának van-e relevanciája a terrorcselekmények megítélésekor? Ennek megválaszolásához az elkövetett cselekmény mellett az elkövető személyét is figyelembe kell venni. Ugyanis eltérő a büntetőjogi megítélése a civil által és katona (hivatásos rendőr, csendőr stb.) által elkövetett cselekménynek. Ennek hagyományosan az az oka, hogy a hivatásos állományú személy kapott kiképzést a fegyverhasználatról, továbbá egy olyan hierarchizált szervezetben szocializálódott, amelynek müködését részben a fizikai erőszak alkalmazása és a megfélemlítés határozza meg. Mindez a kiképző táborokban edzett, kifejezetten a lakosság megfélemlítésére felkészített terroristákról is elmondható. A különbség

\footnotetext{
${ }^{22}$ A CNN Presents c. müsorban, amely 2002. január 12-én volt adásban megszólaltatták Viet DiHNt, aki 20012003 között az Egyesült Államok legfőbb ügyészhelyettese volt és egyben a hírhedt U.S.A.P.A.T.R.I.O.T.A.C.T. kodifikálásáért felelős személy. Mikor számonkérték rajta a hatóságok túlkapásait és a terrorizmus miatt őrizetbe vett személyek formális meggyanúsítás nélküli fogva tartását, azt válaszolta, hogy a hatóságok egyszerüen élnek a jogszabály nyújtotta lehetöségekkel. Az Egyesült Államok lakosságának több, mint 60 \%-a egyetértett a katonai törvényszékek illetékességének megállapításával.

${ }^{23} \mathrm{~A}$ harmadik állam által nyújtott anyagi vagy erkölcsi támogatást nem lehetett minden esetben kétséget kizáróan bizonyítani. Ha erre sor került volna, az értelemszerüen egy jogszerü casus bellivel ért volna fel.

${ }^{24}$ Max, ABrahms, Matthew, Ward, Ryan, KenNedY: Explaining Civillian Attacks: Terrorist Networks, Principal-Agent Problems and Target Selection. In: Perspectives on Terrorism2018/1., pp. 23-45.; Jan-Erik, LANE: The New Patterns of Warfare: Terrorism against Innocent Civilians. In: Contemporary Issues 2010/1., pp. 6-16. ${ }^{25}$ HofFMANN Tamás: Az emberiesség elleni büncselekmények nemzetközi és magyar jogi szabályozása. In: Államés Jogtudomány 2017/1., pp. 29-53.
} 
a hatályos normák alapján azonban mégis abban áll, hogy az a fajta felelős parancsnoksággal azonosítható hierarchia, amely az állami hadseregekre és a paramilitáris szervezetekre is egyaránt jellemző, nem mutatható ki egyértelműen a terrorszervezetek esetében. Az Iszlám Állam tényleges hatalma alatt álló területek ugyanakkor ezt az elképzelést is árnyalják. ${ }^{26}$

Az Egyesült Államokban komoly hagyománya van annak, hogy a legyőzött ellenséget ne csak politikailag, hanem azt erősítve jogilag is felelősségre vonják. Hiszen a második világháborút követően amerikai kezdeményezésre jött létre a Nürnbergi Katonai Törvényszék és a Tokiói Katonai Törvényszék, utóbbit de jure is az Egyesült Államok konstituálta egyoldalúan. ${ }^{27}$ Ugyanakkor a katonai büntetőeljárást sem fogadják el, mivel a terroristákat nem tekintik jogi értelemben katonának. Egyrészt, szinte minden eleme hiányzik a nemzetközi jog kombattáns fogalmának a terroristák esetében - a megkülönböztető ruházat önmagában nem irányadó, a fegyvert szinte sosem viselik látható módon, az egységes és beazonosítható felelős parancsnokság létezése pedig erősen vitatható. A nemzetközi fegyveres konfliktushoz pedig szükséges, hogy legalább két állam álljon egymással harcban, ez egy terrorszervezet esetében nem állja meg a helyét. Másrészt pedig a terroristák a fegyveres konfliktusok során követendő szabályok mindegyikét figyelmen kívül hagyják. Mindezek alapján jutnak többen ${ }^{28}$ arra, hogy a megfelelő megoldás az lehet, ha a terrorizmusra, mint különleges helyzetre különleges jogi választ adnak: egy ad hoc bíróság és eljárásjog formájában. Ezt az elképzelést az európai államok egyértelműen elítélik és minden terrorizmussal kapcsolatos eljárást hagyományos módon, a (civil) büntetőeljárásjog keretei között értékelnek. ${ }^{29}$

Ahhoz, hogy a terrorizmus jogrendszeri hatásait értékelni tudjam, komplex megközelítésben vizsgáltam meg a terrorizmusra és az extrémizmusra adott jogon kívüli és jogalkotói válaszokat. Az extrémizmus részleges vizsgálatára azért volt szükség, mert a kutatás során egyértelművé

\footnotetext{
${ }^{26}$ Audrey, KURTH CRONIN: ISIS is not a terrorist group Why Counterterrorism Won't Stop the Latest Jihadist Threat. In: Forreign Affairs 2015. March/April https://www.foreignaffairs.com/articles/middle-east/2015-0218/isis-not-terrorist-group (letöltés dátuma: 2019. 09. 29.)

${ }^{27}$ A Charter of the International Military Tribunal For the Far East címủ proklamációval a szövetségesek föparancsnoka Douglas MacArthur vezérörnagy létrehozta a Törvényszéket, amelyben aztán 11 állam bírái és ügyészei vettek részt. A Törvényszék létrehozatalát megelőző konszenzus hiányát az okozta, hogy az érintett államok nem tudtak megegyezni abban, milyen jelleggel és mértékben vonják felelősségre a japán háborús bünösöket.

${ }^{28}$ Lásd 21. lábjegyzet. Ezek egyik kritikai értékelésére lásd Laurence H., TRIBE: Trial by Fury. In: The New Republic. 2001. 11. 29. http://www.freerepublic.com/focus/fr/583586/posts (letöltés dátuma: 2019. 09. 29.)

${ }_{29}$ Anne Michèle, IMOBERSTEG HARVEY: Terrorism: A type of organised crime or an offence sui generis? Similarities and differences in the Australian and European Union legislative approaches. $\mathrm{PhD}$ Thesis University of Western Australia. 2013.https://api.researchrepository.uwa.edu.au/files/9835308/Imobersteg_Harvey_Anne_2013.pdf (letöltés dátuma: 2019. 09. 29.)
} 
vált, hogy a 21. században, az online toborzás és radikalizálódás korában, nem lehet pusztán történeti-hagyományos alapokon különválasztani a kettőt, továbbá egy-egy erőszakos cselekmény utólagos értékelésénél a kettőt nem is lehet érdemben külön tartani egymástól. A kutatás nem kizárólagosan egy szelektált jogterületre fókuszált, mivel a jogrendszeri hatások eleve több területen fejtenek ki hatást párhuzamosan, továbbá a megoldások keresése sem lehet ebből fakadóan exkluzív. Hanem a vizsgált államok legjobb gyakorlatát (best practice) követve vizsgálta, hogy vajon ki lehet-e alakítani egy olyan itinert, amely egyszerre alkalmas arra, hogy eredményesen lépjen fel a terrorizmus ellen és egyben rezerválja a demokratikus értékeket. 


\subsubsection{Második hipotézis: Az alkalmazott terrorellenes jogi eszközök közötti fokozatosság eltünt}

Az államok különbözőképpen lépnek fel a terrorizmus ellen, amelynek egyes államokban nagyobb hagyományai vannak, máshol a terrorizmussal való találkozás újszerü élmény. Megint máshol pedig a terrorizmus távolmaradása ellenére szükségszerüségből vagy célszerüségből valamilyen módon próbálnak felkészülni a terrorizmus esetleges későbbi megjelenésére. A terrorizmus elleni fellépést súlyosan leegyszerüsítő lenne pusztán a bủnüldöző szervek nyomozati (felderítés, megelőzés, üldözés) tevékenységével azonosítani. A szociális ellátórendszer radikalizációs folyamatot észlelő-megelőző tevékenységétől ${ }^{30}$ kezdve, a különféle kormányzati ${ }^{31}$ és civil deradikalizációs kezdeményezéseken ${ }^{32}$ keresztül, a társadalom önkéntes részvételéig ${ }^{33}$ bezárólag számos formája van a nem jogi, illetve kifejezetten nem büntetőjogi eszközöknek. A terrorizmus finanszírozásának vagy a terrorista kiképzésben való részvételének a kriminalizálása nem hozott átütő sikereket ${ }^{34}$ a terroristák aktivitásának érdemi visszaszorításában.

Az ENSZ Biztonsági Tanácsa 2001. szeptember 28-án alkotta meg 1373. sz. határozatát, amely valamennyi államra nézve megtiltja a terrorizmus bármilyen formában történő anyagi

\footnotetext{
${ }^{30}$ Ilyen pl. az Európai Unió Radicalization Awerness Network (RAN) kezdeményezése, amely első sorban a szociális ellátórendszerre épít, illetve a szociális ágazatba tartozó személyek aktív közremüködését (észlelését) tartja a rendszer legfontosabb elemének és riasztási pontjának.

https://ec.europa.eu/home-affairs/what-we-do/networks/radicalisation_awareness_network_en (letöltés dátuma: 2019. 09. 29.)

31 https://www.gouvernement.fr/en/the-fight-against-jihadism-is-the-great-challenge-of-our-generation (letöltés dátuma: 2019. 09. 29.) - A francia kormány kezdeményezését aztán félévvel később a helyi lakosság folyamatos tiltakozásának hatására bezárták.

32 A szélesebb gyakorlat viszonylag naprakész értékelésére lásd Daniel, KoEHLER: Understanding Deradicalization. Methods, tools and programs for countering violent extremism. Routledge 2016., p. 306

${ }^{33}$ Ebbe a körbe tartozik első sorban a lakosság felkészítése olyan szituációkra, amelyekben megtanítják, hogyan kell terrortámadás közben viselkedni, illetve a második világháború alatti ellenséges kémtevékenységre vonatkozó tudatossághoz hasonló éberség megteremtése az esetleges veszélyforrások detektálására.

${ }^{34}$ Siker ebben a vonatkozásban az lett volna, ha az európai államokhoz kötődő állampolgárságú személyek által elkövetett terrorcselekmények száma csökken vagy visszaszorul. Mindeközben a második vagy harmadik generációs muszlim bevándorlók, sőt, az eredetileg nem muszlim vallású fehér európai fiatalok radikalizálódása az elmúlt 1,5 évtizedben soha nem látott számokat mutatott. Peter R., Neumann: Countering Violent Extremism and Radicalisation that Lead to Terrorism: Ideas, Recommendations, and Good Practices from the OSCE Region. (Report) 28. September 2017 https://www.osce.org/chairmanship/346841?download=true (letöltés dátuma: 2019. 09. 29.); Bruce, HofFMAn, William, Rosenau, Andrew J., Curiel, Doron, ZimMERMANN: The Radicalisation of Diasporas and Terrorism. A Joint Conference by the RAND Corporation and the Center for Security Studies, ETH Zürich. RAND 2007. https://www.rand.org/content/dam/rand/pubs/conf proceedings/2007/RAND CF229.pdf (letöltés dátuma: 2019. 09. 29.); külön figyelmet érdemel az Identity Vulnerability koncepció, ehhez lásd Christy Garce, Provines: Understanding Radicalization Through the Lens of 'Identity Vulnerability'. In: Columbia Journal of International Affairs. 29. September $2017 \mathrm{https://jia.sipa.columbia.edu/online-articles/understanding-}$ radicalization-through-lens- $\% \mathrm{E} 2 \% 80 \% 98$ identity-vulnerability\%E2\%80\%99 (letöltés dátuma: 2019.09 .29$. )
} 
támogatását, míg a terrorista kiképzésben való részvétel megítéléséről alapvetően a nemzeti büntetőjogban döntöttek ${ }^{35}$ az államok, reagálva az Iszlám Állam ${ }^{36}$ megalakulására. Az erőteljes nemzetközi és nemzeti fellépések ellenére az európai közbeszédet 2014-2017 között egyértelmüen a terrorizmus ${ }^{37}$ határozta meg. ${ }^{38}$

A büntetőjog ultima ratio jellege mellett több alapvető, garanciális szabály ${ }^{39}$ érvényesül, amelyek azt a célt szolgálják, hogy a nyomozati szervek és a bíró, akik értelmezik és alkalmazzák a jogot, megfelelö jogállami keretek között mozogjanak. Ma azonban sokszor nem egyértelmű a terrorizmus elleni fellépés kapcsán, hogy meddig terjednek a büntetőeljáráshoz kapcsolódó jogkörök és honnan térünk át teljes egészében a tisztán közigazgatási hatósági jogkörökhöz? Az első gázolásos terrortámadások után komolyabban elkezdték szürni a gépjármükölcsönzésért folyamodókat, illetve a 2015-ös koordinált párizsi terrortámadások után az ezer föt is befogadni képes szórakozóhelyek, koncerttermek és éttermek számára regisztrációs kötelezettséget írtak elő a hatóságok Franciaországban. Mindkét esetben közigazgatási hatósági jogalkalmazásról volt szó, amelyek nem is minden esetben voltak szankcióhoz rendelve, ${ }^{40}$ a hatóságok fellépése azonban nem sokban különbözött egy átlagos nyomozástól. Más megközelítésben pedig elég csak arra gondolni, hogy az eljárás alá vont civil lakosság szempontjából érzékelhetö-e tényleges különbség a rendőrség terrorfelderítő tevékenysége és a katonaság különleges jogrendhez kapcsolódó rendfenntartó tevékenysége között (pl. egy közúti ellenőrző-áteresztő ponton történő áthaladás alkalmával)? Mindehhez társul még a hagyományosan és tipikusan különleges jogrendi, tehát alapvetően átmeneti

\footnotetext{
${ }^{35}$ Lásd a Financial Action Task Force (FATF) ajánlását, amely több állami gyakorlat bemutatásával javasolja, hogy a terrorista kiképzésben való részvételt, az e célból megtett utazást stb. kriminalizálják az államok. Az ajánlás 2015-ben az ENSZ BT 2253-as határozatát is megalapozta. https://www.fatfgafi.org/media/fatf/documents/reports/Guidance-Criminalising-Terrorist-Financing.pdf (letöltés dátuma: 2019. 09. 29.); Egy példa erre 2019-ből: a svéd parlament 2019. február 28 -án fogadta el azt a törvénymódosítást, amely 2019. augusztus 1-jével lépett hatályba, és a terrorizmushoz kapcsolódó (járulékos, de nem feltétlenül erőszakos) cselekményeket is kriminalizálta, legfeljebb hat évig terjedö szabadságvesztéssel fenyegetve az elkövetőket. https://www.regeringen.se/49344e/contentassets/99eddffed5754ec483fd385d6c397a03/ett-sarskilt-straffansvarfor-deltagande-i-en-terroristorganisation.pdf (letöltés dátuma: 2019. 09. 29.)

${ }^{36}$ Az Iszlám Állam egy 1999-től létező terrorszervezet, amely hatalmának csúcsán a polgárháború sújtotta Szíria és Irak jelentős területeit tartotta a tényleges hatalma alatt és az elmúlt évek jelentős európai terrortámadásait mondta magáénak.

${ }^{37}$ A terrorizmus és a migráció. Lásd Eurobarometer.

${ }^{38}$ Az európai közlekedés fejlesztési koncepció kidolgozásakor csakúgy, mint a hazai és a nemzetközi turizmus visszaesése vélhető okainak vizsgálatakor. Lásd a Eurostat Panorama on Tourism és a Eurostat Year Book Transport fejezeteit a vonatkozó kiadványokban.

${ }^{39}$ Ezek közismerten a nullum crimen sine lege, a nullum crimen sine cupla és a nulla poena sine lege.

${ }^{40}$ Ilyen volt például, amikor Párizs rendőrfönöke 2015-ben felhívásban kérte a szórakozóhelyek tulajdonosait és üzembentartóit, hogy bizonyos fokú biztonsági szüréseket végezzenek el a beléptetés alkalmával. https://www.thelocal.fr/20161111/what-happened-in-france-after-the-paris-terror-attacks (letöltés dátuma: 2019. 09. 29.)
} 
szabályoknak a normalizálása, vagyis a rendkívüli helyett a rendes jogrendbe történő transzformálása. Egy terrorcselekményt követően a terrorizmus ismételt bekövetkezésének veszélye közvetlenül hat a lakosság magatartására, amely így bizonyos - normatív kötőerővel nem megerősített - állami instrukciók esetében az önkéntes jogkövetésnél is hatékonyabban szolgálja az állam jogszociológiai elvárásait. ${ }^{41}$

A probléma tehát komplexebb, mint elsőre tűnik, hiszen nem csupán egy jogágon belül jutunk el viszonylag egyszerüen a legerősebb eszközök alkalmazásáig, de a jogágak közötti végső soron szabad szemmel is látható elhatárolás is, sokszor úgy tủnik, elkopott. Egyes különleges jogrendi elemeket (pl. a hatósági jogkörök gyakorlásához kapcsolódó bírói felülvizsgálat korlátozása) pedig nyíltan vállalva emeltek át a rendes jogrendi elemek közé. ${ }^{42}$

A fokozódó biztonsági kihívásra (veszélyforrások gyakoribbá válása, bűnözés elterjedése, általános társadalmi morál romlása) a jogalkotó hagyományosan úgy reagál, hogy új jogintézményt hoz létre (pl. az ún. Diplock-bíróságok ${ }^{43}$ Észak-Írországban), vagy a hatályos szabályozást úgy változtatja meg, hogy az állam eredményesebben tudjon fellépni a jogállami jogrendszer számára nehezen vagy egyáltalán nem kezelhető kihívásokkal szemben (pl. új szabálysértési vagy büntetőjogi tényállás létrehozása, vagy meglévő tényállások szankcióinak szigorítása). Ez a fokozatosságnak egy direkt vagy egyértelmű formája. A fokozatosság erodálódását, illetve új értelemmel való feltöltését jelzi, hogy a hagyományos - tehát eredetileg is egyértelmü kapcsolatban álló - jogintézmények érintetlenül hagyása mellett a jogalkotó különböző jogágakat egyidejűleg, párhuzamosan vagy egymásra tekintettel módosít (pl. a terroristák online toborzásának visszaszorítására és megakadályozására tett lépések egyszerre érintik a hatóságok és az Internetes szolgáltatók mellett a felhasználókat is - értelemszerüen különböző jogágakat érintve). A fokozatosság egy sokkal látványosabb mellőzése, amikor a rendes és a rendkívüli jogi eszközöket vegyesen, illetve vegyítve alkalmazzák, vagy esetleg a tipikusan a különleges jogrendbe tartozó jogi megoldásokat a normál jogrendbe illesztik (pl. a

\footnotetext{
${ }^{41}$ Ezt szemléltető példa volt, amikor az Egyesült Királyság oktatásért felelős kormánytagja 2013-ban arra kérte a középiskolák fenntartóit, igazgatóit, tanárait és a diákok szüleit, hogy a Franciaországba tervezett osztálykirándulásokat halasszák el vagy mondják vissza és helyette az Egyesült Királyságban maradjanak a terrorveszélyre való tekintettel. https://www.express.co.uk/news/uk/620616/New-Paris-terror-WARNINGBritish-schools-ordered-to-BAN-school-trips-to-France (letöltés dátuma: 2019. 09. 29.)

${ }^{42}$ Az Egyesült Királyság, Kanada és az Egyesült Államok vonatkozásában lásd James. C., SimEON: The Evolving Common Law Jurisprudence Combatting the Threat of Terrorism in the United Kingdom, United States and Canada. In: Laws. 2019/5. https://www.mdpi.com/2075-471X/8/1/5/htm (letöltés dátuma: 2019. 09. 29.); a francia jogrendből lásd a 2017-1510. számú törvényt, amelyet az értekezés részletesen elemez a későbbiekben.

${ }^{43} \mathrm{Az}$ ún. Diplock-bíróságokkal az értekezés a későbbiekben részletesen foglalkozik.
} 
franciaországi hosszú, 2015-2017 között fennálló különleges jogrendi időszakot felváltó, sokak által vitatott törvénykezés). Az elmúlt évek terrorellenes állami fellépésének egyik sajátossága, hogy sokszor, amikor egyébként akár indokolt is lehetne, mégsem kerül sor jogalkotásra. Az elmaradt jogalkotás helyett a hatályos jogot veszik alapul és a normaszöveget új tartalommal töltik fel (kiterjesztő jogértelmezés) vagy az absztrakció - egyébként veszélyes - eszközével élnek. Mivel ezek közül egyik sem kecsegtet makulátlan megoldással a jogállami elvárások szempontjából, ezért még gyakoribb a metajurisztikus eszközök választása. A terrorellenesség hatékonyságához füzött remények azonban sokszor ahhoz vezetnek, hogy olyan jogrendszeren túli magatartásszabályokat irányoznak elő az állami hatóságok - ajánlások és szankcióhoz nem kötött iránymutatások formájában -, amelyek aztán társadalomra gyakorolt hatásukat tekintve vajmi kevés dologban különböznek a szankcióval megtámogatott normatív hatósági rendelkezésektől. (Pl. a külföldről ellesett gyakorlat alapján, de megfelelő legitimációt biztosító hazai jogszabályi háttér nélkül folytatott a Sziget adatgyüjtést). A Sziget Zrt. a rendezvényein elektronikusan rögzítette a látogatók személyazonosító igazolványait, amelyre jogszabályi felhatalmazásuk nem volt, csupán az érintettek beleegyezése. A NAIH elmarasztalta a Sziget Zrt.-t, amely az eljárásban a 2015. évi franciaországi terrortámadásokra és az ezzel párhuzamosan kialakult európai gyakorlatra hivatkozott. ${ }^{44}$ A jogalkotó a hatósági jogértelmezéssel ellentétes gyakorlatot részesítette előnyben és a továbbiakban a tömegrendezvények szervezői részére kötelezettségként határozta meg a rendezvényekre látogatók adatainak a rögzítését. ${ }^{45}$

${ }^{44}$ Lásd a Sziget Zrt. által szervezett rendezvényeken folytatott, beléptetéssel összefüggő adatkezelések vizsgálatával összefüggésben született NAIH/2019/55/5. számú határozatot. http://www.naih.hu/files/NAIH-2019-55 hatarozat.pdf (2019. 09. 29.)

${ }^{45}$ A személy- és vagyonvédelmi, valamint magánnyomozói tevékenység szabályairól szóló 2005. évi CXXXIII. törvény (új) VI/C. Fejezete a tömegrendezvény szervezőjére vonatkozó különös rendelkezésekről. (A törvény módosítása 2019. július 30-án lépett hatályba, még épp időben a 2019. évi Sziget Fesztivál kezdete előtt.) 


\subsubsection{Harmadik hipotézis: A nemzetközi terrorizmus közvetlen fenyegetettség nélkül is (áttétesen) egy spirális védekező pályára állítja a jogrendszert}

A dolgozat harmadik feltevése, hogy a nemzetközi terrorizmusnak van egy olyan - áttétes hatása, amellyel olyan jogrendszerekre is hatást gyakorol, ahol ténylegesen egyébként nem volt korábban jelen. Attól, hogy egyáltalán nincs számottevő terrorveszély meg kell különböztetni azt, ha van érdemi mértékü terrorveszély, azonban a kormány vagy a parlament arra nem megfelelő ütemezéssel (ideje korán vagy megkésve) vagy nem megfelelö mértékben (alul értékelt vagy túlértékelt veszély) reagál. A reakció ennek a hipotézisnek az esetében mindenképpen jogi válasz lesz. Hiszen az egyes jogrendszeri változtatásokat kizárólag a jog által is érzékelhető terrorveszéllyel vagyunk képesek abból a célból ütköztetni, hogy a valóság és a jogrendszeri változások közötti összefüggést igazolhatóan ki tudjuk mondani.

A tisztán politikai kommunikáció (pl. felvilágosító kampány, intézményesített politikai kérdőív, különösen választási kampányban), a statisztikai adatgyüjtés vagy maga a jogalkotás nélküli kormányázás nem alapozza meg önmagában a terrorizmusra adott jogrendszeri választ. A jogalkotó szándékoltan és direkt módon törekszik olyan módon alakítani a jogrendszert, mintha a terrorizmus közvetlen veszélye állna fenn. Kénytelen ugyanis ezzel a hipotézissel élni, mert egyébként nem lenne megfelelő legitimációja a jogalkotásnak. Mindezt teheti elörelátásból vagy óvatosságból, mert belátja, hogy egy globalizált politikai környezetben, gazdasági, politikai és katonai szövetségi rendszerek tagjaiként nem engedheti meg magának egyetlen állam sem azt a könnyelmüséget, hogy izolációs politikát folytasson. Ez nagyfokú negligencia lenne.

Természetesen szerepet játszanak tisztán politikai érdekek is egy (jog)politikai döntés meghozatalában. Messzemenőkig naivitás lenne azt feltételezni, hogy az egyéb politikai megfontolások figyelmen kívül hagyásával is lehet politikai döntést hozni. A politikai döntés, legyen az jogalkotási vagy nem, de sajátos természetéből fakadóan mindenképpen politikai lesz. Tehát önmagában nem a politikai érdek lesz a kifogásolható elem egy olyan folyamat értékelésekor, amely a terrorveszélyre tekintettel átalakítja a jogrendszert. Legfeljebb annak aránya, hogy a különféle politikai érdekek (nemzetközi, nemzeti, párt- és egyéni politikai érdekek) milyen módon járultak hozzá a döntés meghozatalához. ${ }^{46}$

\footnotetext{
${ }^{46}$ Vö. Barry, BuZAN: People, states and fear: An Agenda for security Analysis in the Post-Cold War Era. Brighton, Wheatsheaf 1991., p. 18.
} 
A dolgozatban részletesen elemzem a terrorizmusra fókuszáló, illetve a közvetetten kötődő tematikájú jogalkotás indirekt megjelenését olyan államokban, ahol a veszély és a veszélyre adott válaszok kapcsolata nem feltétlenül egyértelmű. 


\subsection{A kutatás módszertana}

A doktori képzés megkezdésekor és a kutatási terv összeállításakor, 2010-ben közel tíz évvel voltunk a 9/11-es terrortámadás után, illetve mögöttünk voltak a 2000-es évek közepét meghatározó európai terrortámadások. Az európai célpontok tömegközlekedési eszközök voltak, fegyverként pedig öngyilkos merénylök robbantották fel a magukra szerelt robbanószerkezetet. A támadás tehát beillett a korábbi támadások sorába, legfeljebb az intenzitása és az évtized közepére való koncentráltsága tünhetett fel. 2010-ben ugyanakkor már közel 5 évvel voltunk az utolsó nagyobb terrortámadás után, így látszólag egyértelmü volt, hogy egy történeti-magyarázó kutatással, lineáris gondolatmenettel feltárhatók a hipotéziseket alátámasztó vagy cáfoló bizonyítékok. Azonban a 2012-ben elkövetett toulouse-i és montaubani lőfegyverrel elkövetett terrorcselekményt, 2015-ben követte a Charlie Hebdo elleni terrortámadás. A 2015/16-ban elkövetett kiemelkedő lélekvesztéssel járó támadásokat követően már látszott, hogy valami megváltozott. A terroristák toborzása, kiválasztási módszerei, a fegyverként használt közlekedési eszközök és főként, hogy látszólag a hatóságok képtelenek voltak megakadályozni a további támadásokat, korábban nem tapasztalt kétségbeesést váltott ki az emberekben.

A kutatás tárgyát illetően megváltozott körülmények miatt szükséges volt a kutatási módszerek finomhangolása is. Egyrészt túl sok olyan megvalósult vagy a hatóságok által időben feltárt terrortámadásról szereztünk tudomást, amelyek mennyiségileg ellehetetlenítették volna az események érdemi és mélységi feltárását, majd teljes körü kiértékelését. Másrészt a vizsgálat tárgyát nem maguk a terrorcselekmények, hanem az azokra adott jogállami válaszok jelentették. Ezek viszont időben rendkívül széles skálán mozognak, hiszen a közvetlenül, szinte automatikusan kiváltott válaszok mellett, számos típusú, mélységü, változó hatáskörrel és tervezett élettartammal rendelkező intézkedésről adtak tájékoztatást az érintett országok kormányai. Látható ugyanakkor, hogy a stratégiai terrortámadások ${ }^{47}$ határozzák meg mind a közvélemény, mind pedig politikai döntéshozók biztonság percepcióját és agendáját.

A kutatás során metajurisztikus, jogrendszeri és különleges jogrendbe tartozó elemeket vizsgáltam. A témakör rendkívül szerteágazó, ezért a klasszikus lineáris gondolatmenet és az erre épülő kutatás módszertan helyett, egyes konkrét részelemek vizsgálatával, illetve a

\footnotetext{
${ }^{47}$ Vagyis a nagy áldozatszámmal és jelentős médiafigyelemmel kísért terrortámadások.
} 
gyakorlat értékelésével egy sajátos spirális gondolatmenetet követtem a kutatás során. A dolgozat ennek megfelelően reflektál a terrorizmus ellen felkínált megoldásokra. A kutatás során felmerült néhány primer kérdés, amelyeknek a felvetése és lehetőség szerinti megválaszolása meghatározó volt a kutatás menetét illetően. Az egyik kiemelkedő kérdés, hogy a terrorellenes fellépés eredményessége belügyi kérdés vagy nemzetközi ügy. Ebben a tekintetben párhuzamosan kell vizsgálni a politikai retorikát, ${ }^{48}$ a szakmai beszámolókat ${ }^{49}$ és jelentéseket, valamint az NGO-k ${ }^{50}$ független jelentéseit és neves kutatók ${ }^{51}$ tudományos igényességü írásait. Ezek alapvetően másodlagos források vizsgálatából nyerhetők ki. A kérdés jellegéből adódik, hogy valós idejü és teljes körü értékelésre nem nyílik mód, a belügyi és a nemzetközi eredményességet egyaránt csak retrospektív módon lehet objektíven értékelni.

Az első kérdéstől nem teljesen független, de nem is áll vele rész-egész viszonyban, vagy okokozati összefüggésben, hogy a terrorellenes fellépést melyik jogág keretei között helyezzük el. Fontos, hogy a terrorellenességet ne azonosítsuk kizárólag a büntetéskiszabással, mert sokkal többről van szó. Kimutatható és jelentős mértékű különbség ${ }^{52}$ van a büntetőjogon túli eszközök

\footnotetext{
${ }^{48} \mathrm{Az}$ Európai Unió tagállamai közül az utóbbi években leginkább Franciaország szerepelt a nemzetközi terrorizmussal összefüggésben a hírekben. A francia kormány komplex módon lép fel a terrorizmus ellen, ugyanis felismerte, hogy az új típusú terrorizmusra nem jelenthet adekvát választ a partikuláris eredménypolitika. Vagyis, a külföldön folytatott katonai felderítő, harcászati és egyéb műveletek, a belföldön végzett rendöri és nemzetbiztonsági felderítő tevékenység, valamint a diplomáciai tevékenység és a radikalizáció megelőzése érdekében kifejtett tevékenység külön-külön nem alkalmas arra, hogy hosszútávon sikereket biztosítson a terrorizmus elleni küzdelemben. Erröl lásd bővebben a francia külügy tárgyban született tájékoztatóját: https://www.diplomatie.gouv.fr/en/french-foreign-policy/security-disarmament-and-non-proliferation/terrorismfrance-s-international-action/ (letöltés dátuma: 2019. 09. 29.); összehasonlításképpen lásd CROTTY, pp. ix-xiii.

${ }^{49}$ Kezdve a kormányzati beszámolóktól, pl. https://www.government.nl/topics/counterterrorism-and-nationalsecurity/counterterrorism (letöltés dátuma: 2019. 09. 29.), a szakmai felsőfokú tanulmányok lezárását követően készített diplomamunkákon keresztül, pl. https://www.verfassungsschutz.de/de/das-bfv/akademie-fuerverfassungsschutz/pb-diplomarbeiten (letöltés dátuma: 2019. 09. 29.), egyebek mellett a közvéleménykutatásokig, pl. Steve, Farkas, Jean, Johnson, Ann, Duffett, Kathleen, Collins: Aggrevating Circumstances. A Status Report on Rudness in America. A report from Public Agenda. 2002 p. 36. https://www.google.com/url?sa=t\&rct=i\&q=\&esrc=s\&source=web\&cd=1\&ved=2ahUKEwiTurC0i4DmAhXIk4 sKHVDFCtEQFjAAegQIARAC\&url=http\%3A\%2F\%2Fresearch.policyarchive.org\%2F5628.pdf\&usg=AOvVa w38pM95kGy01FCCl dmUb3Z (letöltés dátuma: 2019. 09. 29.), illetve sajtó nyilatkozatokig, pl. http://www.eurojust.europa.eu/press/PressReleases/Pages/2019/2019-09-05.aspx (letöltés dátuma: 2019. 09. 29.)

${ }^{50}$ A számtalan nem kormányzati kutatószervek közül a szakmai teljesítményük alapján ezeket érdemes kiemelni: a hágai székhelyü International Centre for Counter-Terrorism, az amerikai RAND Corporation, vagy bizonyos kutatások finanszírozása kapcsán a Konrad Adenauer Stiftung.

${ }^{51}$ A teljesség igénye nélkül lásd Theodor H., WinkLer, Anja H., EBNÖTHer, Mats B., HANSON (eds.): Combating Terrorism and Its Implications For the Security Sector. Swedish National Defence College, Stockholm 2005. https://www.dcaf.ch/sites/default/files/publications/documents/Combat Terrorism webb.pdf (letöltés dátuma: 2019. 09. 29.); különösen a nemzetközi terrorizmussal összefüggésben megnövekedett a nemzetbiztonsági szolgálatok nemzetközi együttműködése, amelyröl lásd bővebben: Hans, BoRN, Ian, LEIGH, Aiden, WILLIS (eds.): International Intelligence Cooperation and Accountability. Routledge, London, New York, 2012., pp. 22-50., 96144.

${ }^{52}$ Lásd European Court of Auditors Special Report No. 13 2018: Tackling radicalisation that leads to terrorism: The Commission adressed the needs of Member States, but with some shortfalls in coordination and evaluation.
} 
megelőző politikája és a kizárólag a hátrányos jogkövetkezményekre koncentráló, de végső soron mégiscsak utólagos fellépés között. Egy további kérdés, hogy miként alakítja a terrorizmus a demokratikus jogállami értékrendet, a célpont államok és társadalmaik miként reagálnak a terrorveszélyre, illetve léteznek-e olyan alapvető értékek, amelyekhez változatlanul ragaszkodunk? Mindezt annak a fényében kell megválaszolnunk, hogy ellentmondásosnak tünő gyakorlat alakult ki a jogértelmezést illetően. Az Egyesült Királyságban a Magna Charta 1215ös kiadása óta hatályban lévő 39. cikkely ${ }^{53}$ kizárja annak lehetőségét, hogy valakit jogerős bírósági ítélet vagy legalább folyamatban lévő büntetőeljárás, vagyis gyanúsítás vagy vád nélkül határozatlan ideig fogva tartsanak. Ugyanakkor, ha az Emberi Jogok Európai Bíróságának gyakorlatát nézzük a terroristák fogva tartását illetően, világosan látszik, hogyan változik ténylegesen a bírói jogértelmezés a társadalmi valóságra tekintettel. ${ }^{54}$ Korábban nagyon komolyan hangoztatott politikai érv volt a terrorizmus értelmezésekor, hogy a terroristák nemcsak fizikai és anyagi kárt okoznak, hanem a félelemkeltés valódi célja az, hogy a nyugati társadalmak változtassanak az életmódjukon és ehhez a végsőkig fogunk ragaszkodni. ${ }^{55}$ Ezzel ellentmondásban áll, hogy szinte lehetetlen a mindennapokból olyan területet mondani, amelyre ne gyakorolt volna valamilyen befolyást az elmúlt két évtized terrorizmusa. ${ }^{56}$ Hasonlóan jelentős társadalmi-politikai vitákat szült az elmúlt évtizedekben a terroristák kiadatásának kérdése. ${ }^{57} \mathrm{Nem}$ mindegy az sem, hogy kizárólagos állampolgársága

https://www.eca.europa.eu/Lists/ECADocuments/SR18_13/SR_RADICALISATION_EN.pdf (letöltés dátuma: 2019. 09. 29.)

${ }^{53} \mathrm{https} / / /$ www.parliament.uk/about/living-

heritage/evolutionofparliament/originsofparliament/birthofparliament/overview/magnacarta/magnacartaclauses/ (letöltés dátuma: 2019.09. 29.)

${ }^{54}$ Az Emberi Jogok Európai Bíróságának 1961-es döntése a Lawless v. Írország ügyben, valamint a 2009-es A. és mások v. Egyesült Királyság ügyben hozott döntés.

${ }^{55}$ Fontos, hogy ne lássuk a különbséget az Emberi Jogok Európai Nyilatkozatának 15. cikkében említett „, life of the nation " jelentés tartalma nem azonos az Európai Néppárt frakciójának nyilatkozatában említett ,w way of life" kifejezéssel Combatting Islamist Terrorism and Protecting our Way of Life. Resolution adopted by the EPP Political Assembly, Brussels 4th-5th December 2017 https://www.epp.eu/files/uploads/2017/12/CombattingIslamist-Terrorism-and-Protecting-our-Way-of-Life-1-1.pdf (letöltés dátuma: 2019. 09. 29.)

${ }^{56}$ https://www.parlament.hu/irom41/06552/06552.pdf; http://naih.hu/files/NAIH-2019-55 hatarozat.pdf (letöltés dátuma: 2019. 09. 29.); https://www.thelocal.fr/20161111/what-happened-in-france-after-the-paris-terror-attacks (letöltés dátuma: 2019. 09. 29.); https://www.express.co.uk/news/uk/620616/New-Paris-terror-WARNINGBritish-schools-ordered-to-BAN-school-trips-to-France (letöltés dátuma: 2019. 09. 29.)

${ }^{57}$ Az Emberi Jogok Európai Egyezményének vívmányait az 1998-as Human Rights Act ültette át az Egyesült Királyság jogrendszerébe, amelyre a brit jogrendszer sajátosságai miatt volt szükség. A Special Immigration Appeals Commission az 1997-es azonos elnevezésü törvény által jött létre, amely illetékességgel rendelkezik azoknak az ügyeknek a vonatkozásában, amelyek külföldi állampolgárságú személyek kitoloncolásával járnának együtt. A brit jog nem teszi lehetővé azon személyek kitoloncolását, akik a célországban az általuk elkövetett büncselekmények miatt kínzás vagy embertelen bánásmód veszélyének lennének kitéve. Az Egyesült Királyság kormánya közel 10 éven át próbálkozott 6 algériai állampolgárságú személy kitoloncolásával. Ehhez még az algériai kormány nyilatkozatát is beszerezték, amelyben nyilatkoznak arról és egyben kötelezettséget is vállalnak arra, hogy tiszteletben fogják tartani a terrorizmus vádjában bünösnek kimondott állampolgárait fogva tartásuk ideje alatt. Az Egyesült Királyság bírósága ugyanakkor ezt sem tartotta kielégítőnek és a 6 férfi továbbra is marad a brit börtönben. Lásd bövebben: $B B, P P, W, U$ and Others and Secretary of State for the Home Department Royal 
szerinti kiadatásról, többes állampolgárság esetén a kiadatási desztinációt illető ${ }^{58}$ önkényes választásról, vagy esetleg olyan harmadik államnak történő kiadásról van szó, amelyhez állampolgári jogviszony nem füzi az érintettet, legfeljebb az elkövetett büncselekmény ${ }^{59}$ vagy esetleg az sem. ${ }^{60}$

A terrorizmusra adott válaszok egyidejüleg és párhuzamosan keletkeznek a metajurisztikus és a jogrendi elemek esetében, illetve az elmúlt évtizedek jogfejlődéséből látható, hogy a terrorizmus permanens módon megvetette a lábát a különleges jogrend keretei között is. A kutatás során felhasználtam normatív szövegeket, alkotmánybíróságok és felsőbb bíróságok által adott jogértelmezést, valamint a bírósági joggyakorlatot, a kormányzati vagy a hatóságok által folytatott hivatalos kommunikációt, közvélemény-kutatásokat és statisztikai adatokat, valamint szakmai és tudományos elemzéseket, tanulmányokat és egyéb tudományos írásokat. A kutatás során a parlamenti és kormányzati oldalakon megtalálható hivatalos információkból, jelentésekből és joganyagokból dolgoztam, továbbá vizsgáltam egyes kutatóintézetek és egyetemek által kidolgozott tudományos minőségü tanulmányokat.

Courts of Justice 23. January 2015 http://siac.decisions.tribunals.gov.uk/Documents/W-and-Others-open18Apr16.pdf (letöltés dátuma: 2019. 09. 29.)

${ }^{58}$ Lásd Maher Arar szíriai-kanadai kettősállampolgár esetét, akit egy tunéziai nyaralást követően 2002 szeptemberében tartóztattak le hivatalos gyanúsítás nélkül. Ugyan az állandó lakcíme és az útiokmánya, amivel átutazóban volt az Egyesült Államokon keresztül kanadai volt, mégis az amerikai hatóságok Damaszkusznak adták át. Emberi jogvédő szervezetek és a kanadai kormány szerint azét, mert Szíriában a terrorizmussal gyanúsított fogva tartottakat - további információk reményében - megkínozzák, illetve embertelenül bánnak velük. Lásd bövebben: Report of the Events Relating to Maher Arar. http://epe.lac-bac.gc.ca/100/200/301/pcobcp/commissions-ef/arar-ef/commisionners report/index.html (letöltés dátuma: 2019. 09. 29.) Commission of Inquiry into the Actions of Canadian Officials in Relation to Maher Arar. Her Majesty the Queen in Right of Canada represented by the Minister of Public Works and Government Services, Ottawa, Canada, 2006. http://www.sirc-csars.gc.ca/pdfs/cm arar bgv1-eng.pdf (letöltés dátuma: 2019. 09. 29.)

${ }^{59}$ Lásd Abu Omar vagy teljes nevén Hassan Mustafa Osama Nasr elrablását Milánóból a CIA által és az olasz nemzetbiztonsági szolgálatok passzív közremüködésével, majd Egyiptomnak való kiadatását, ahol aztán a tényleges kínzások megtörténtek: https://verfassungsblog.de/state-secrecy-in-counterterrorism-different-judicialstandards-of-review-the-abu-omar-case-before-italian-courts/ (letöltés dátuma: 2019. 09. 29.)

${ }_{60}$ Khalid el-Masri nevét a macedón hatóságok tévedése és túlzott óvatossága juttatta a CIA skopjei rezidentúrájának a figyelmébe, akik aztán elrabolták őt és a hírhedt „Salt Pit” elnevezésű fogvatartási helyen (valójában kínvallatásra használt objektuma volt a CIA ún. blacksite hálózatának) tartották fogva. Az események összefoglalására lásd az Emberi Jogok Európai Bíróságának tárgyban készült dokumentumát http://hudoc.echr.coe.int/fre?i=001-110887 (letöltés dátuma: 2019. 09. 29.) 


\subsection{A terrorizmusra vonatkozó szabályok megjelenése a jogrendszerekben}

A terrorizmus mint a kormányzás megfélemlítés által, vagyis a Franciaországban 1789-94 között alkalmazott állami-irányítási és politikai módszer volt. Az idők során a terrorizmus jelentése változott, kiegészült és a 20. század második feléig szinte kizárólagosan olyan személyekre vagy csoportokra használták, amelyek nacionalista vagy más politikai meggyőződésből erőszakot alkalmaztak és közvetlenül (másként: hivatalosan) nem állt mögöttük harmadik állam. A szakértelem vagy az információ hiánya miatt azonban ma rendkívül változatos erőszakos cselekményekre akasztják rá a terrorizmus billogját, nem beszélve arról, hogy nem is kell feltétlenül minden esetben ténylegesen erőszakos cselekményt elkövetni. ${ }^{61}$

A klasszikus európai megközelítés egyértelműen büntetőjog-orientált, ${ }^{62}$ amely azért fontos a cselekmény értékelésénél, mert az üldözésre és a reagálásra ugyan megfelelő választ ad, de a megelőzésre és az értékelésre ${ }^{63}$ többféle választ kell adnia a jogrendszernek. Egy nacionalistafüggetlenségi terrorista és egy iszlámista harcos által elkövetett terrorista cselekmény büntetőjogi megítélése történhet azonos tényállási alapról, ugyanakkor a radikalizáció nyomainak detektálása és a deradikalizáció sikeressége nagyban múlik a megközelítés differenciáltságán. ${ }^{64}$

Szemléltető példa erre, hogy alakilag és anyagilag is ugyanazt a cselekményt - amely a lehetséges célpontokra vonatkozó információátadás, tippadás volt - hogyan értékelte eltérōen a brit és az ír jogrendszer az ún. Troubles ${ }^{65}$ időszakában. Az eltérő szempontrendszer annak

\footnotetext{
${ }^{61}$ Az Egyesült Államokban a „domestic terrorism” kifejezés először 2003-ban jelent meg, ugyanakkor a fogalom jelentését illetően - a jellemzően éppen ellenzéki részéről - éles kritika éri, miszerint a szóhasználat (ti. terrorizmus) pontatlan és összemossa a nemzetközi iszlamista terrorizmussal, ezáltal pedig utóbbihoz tartozó cselekményeket teszi súlytalanná. Vitatott, hogy mit is tekint az amerikai jogrendszer és a politika az ún. domestic terrorism körébe tartozónak. Ugyanis, míg a több tucat ember halálát okozó tömegmészárlást egyszerủen ámokfutásnak titulálják és mentális zavarodásra hivatkoznak, addig a szövetségi intézmények müködését fizikailag akadályozó környezetvédelemért felszólaló tüntetőket rendre a terroristákhoz sorolják. Lásd https://www.nytimes.com/2019/08/11/us/politics/domestic-terrorism.html (letöltés dátuma: 2019. 09. 29.) és https://theintercept.com/2019/03/23/ecoterrorism-fbi-animal-rights/ (letöltés dátuma: 2019. 09. 29.)

${ }^{62}$ Jól mutatja az európai megközelítést, hogy a 9/11-es merényletek hatására a korábban létezö európai kiadatási rendszert lecserélték 2002-ben az európai elfogató parancsra, amely egyértelműen egy megkezdett büntetőeljárást feltételez.

${ }^{63}$ Lásd az Európai Unió Terror-elháritási Stratégiáját https://www.consilium.europa.eu/en/policies/fight-againstterrorism/eu-strategy/ (letöltés dátuma: 2019.09.29.)

$64 \quad$ https://foreignpolicy.com/2018/11/23/want-to-deradicalize-terrorists-treat-them-like-everyone-elsecounterterrorism-deradicalization-france-sri-lanka-pontourny-cve/ (letöltés dátuma: 2019. 09. 29.)

65 A függetlenségért küzdő, republikánus katolikusok és a lojalista és unionista protestánsok között ÉszakÍrországban több, mint 3000 halálos áldozattal járó fegyveres harcokat nevezik így a brit politikatörténetben.
} 
ellenére érvényesült a cselekmények azonos idejü jogi megítélésében, hogy a nyomozati cselekményt, amelyben felmerültek, összehangoltan, a két állam hatóságainak együttmüködésében folytatták le. A differenciált megítélésre utólag, a két érintett ország parlamentjeinek felkérésére került sor, amikor bírák folytatták le az eljárásokat. ${ }^{66}$

A terrorizmus elleni fellépés vonatkozásában a kutatók és szakértők többsége egyetért abban, hogy a hatékony nemzetközi együttmüködés és az összehangolt fellépés elengedhetetlen a terrorizmus visszaszorításához, a kevesek által hirdetett izolációs politika pedig nem garancia a biztonságra. ${ }^{67} \mathrm{Az}$ első nemzetközi együttműködést elöíró nemzetközi szerződés a Nemzetek Ligája által kidolgozott, az 1937-es A terrorizmus megelőzéséről és büntetéséről szóló Konvenció, amelyet egyedül Brit-India kormánya ratifikált, így gyakorlatilag elhalt és a második világháborút követően egyébként is az ENSZ létrejöttével új alapokra helyezték a nemzetközi együttműködések rendszerét. A konvenciót az Egyesült Királyság kormánya egyébként éppen politikai és jogi alapokra hivatkozva utasította el. ${ }^{68}$

\footnotetext{
${ }^{66}$ A brit kormány a kanadai legfelsőbb bíróság korábbi tagját, Peter Coryt kérte fel, hogy vizsgálja ki az ÉszakÍrország és Î́rország határán átnyúló hatósági és terrorista együttmüködéseket és különösen az információcserét, amely halálos kimenetelü terrorcselekményekhez vezetett. Cory a vizsgálódását követően javasolta az ír kormánynak, hogy egy írországi vizsgálatot is folytassanak le, amelyre aztán az ír District Court korábbi elnökét, Peter Smithwicket kérték fel. Vezetésükkel alakultak meg a Cory Collusion Inquiry és a Smithwick Tribunal. A Smithwick Tribunal jelentése szerint a Garda vezető tisztségviselői közül adták a tippet a két RUC tag 1989-es merényletére, miközben a Gardaval folytatott szakmai egyeztetésről tartottak haza Írországból. Lásd Report of the Tribunal of Inquiry into Suggestions that Members of an Garda Síochána or other Employees of the State Colluded in the Fatal Shootings of RUC Chief Superintendent Harry Breen and RUC Superintendent Robert Buchanan on the $20^{\text {th }}$ March 1989, 2004 (a jelentést csak 2013-ban hozták nyilvánosságra) http://opac.oireachtas.ie/AWData/Library3/smithwickFinal03122013 171046.pdf (letöltés dátuma: 2019. 09. 29.) $\mathrm{Az}$ észak-ír RUC, illetve Army forrásokról lásd Billy Wright https://cain.ulster.ac.uk/issues/collusion/cory/cory03wright.pdf (letöltés dátuma: 2019. 09. 29.), Robert Hamill https://cain.ulster.ac.uk/issues/collusion/cory/cory03hamill.pdf (letöltés dátuma: 2019. 09. 29.), Rosemary Nelson https://web.archive.org/web/20070108152316/http://www.nio.gov.uk/cory collusion inquiry report \%28witho ut appendices\%29 rosemary nelson.pdf (letöltés dátuma: 2019. 09. 29.), Patrick Finucane https://web.archive.org/web/20070108152519/http://www.nio.gov.uk/cory collusion inquiry report \%28with appendices\%29 pat finucane.pdf (letöltés dátuma: 2019. 09. 29.), legutóbbiról készült a 2012-es ún. De Silva Report

https://assets.publishing.service.gov.uk/government/uploads/system/uploads/attachment data/file/246867/0802.p df (letöltés dátuma: 2019. 09. 29.)

${ }^{67}$ Képtelen illúzió volna, ha egy állam arra hivatkozna, hogy az állampolgárai és a gazdasági érdekeltségei számára külföldön is immunitást biztosít a teljes elzárkózás politikája.

Anthony H., CoRdesman: International Cooperation in Counterterrorism: Redefining the Threat and the Requirement. Center for Strategic and International Studies 2010 https://csis-prod.s3.amazonaws.com/s3fspublic/legacy files/files/publication/100316 New Reports International Cooperation Counterterrorism.pdf (letöltés dátuma: 2019. 09. 29.)

${ }^{68}$ Mary, BARTON: The British Empire and International Terrorism: India's Spearate Path at the League of Nations, 1934-1937. In: Journal of British Studies. The North American Conference on British Studies 2017/2., pp. 351-373.
} 
A terrorizmus, mint jogi fogalom ezt követően elsősorban a nemzeti jogrendszerekbe húzódott vissza, míg a nemzetközi jog inkább csak utalt rá, mint valami látens fogalomra. Bár kétségtelen, hogy több próbálkozás ${ }^{69}$ is volt a terrorizmus fogalmát illetően egy univerzális definíció kialakítására, sőt erre még igény is volt, ${ }^{70}$ ám ezek nem jártak sikerrel. A regionális nemzetközi egyezmények már több sikerrel jártak. Ennek oka vélhetően egyszerüen abban található, hogy az értékek és az érdekek regionális szinten hasonló képet mutatnak, illetve az eltérő nézetek könnyebben feloldhatók egy homogén nemzetközi politikai környezetben. A regionális egyezmények definícióiból - a számos különlegesség mellett - kitünik egy jelentés mag, amelyet azonban a Cassesse ítéletig ${ }^{71}$ nem igazán tett senki magáévá. Látható továbbá a Cassesse ítélet ellentmondásos fogadtatásából, ${ }^{72}$ hogy most sem hozta el az univerzális definíció ${ }^{73}$ megszületését.

A kutatás nem törekszik a terrorizmus fogalmának meghatározására, amely önmagában is kimerítene egy doktori kutatást. Látva az elmúlt évtizedek próbálkozásait - és ezek kudarcait a fogalom nemzetközi meghatározására, elmondhatjuk, hogy megkerülhetetlen a politikai elem, amely egyben a legfőbb akadálya is az univerzális definíció megalkotásának. A terrorizmus fogalmának jogtudományi meghatározásában a büntetőjogi tényállás, ${ }^{74}$ az Európai Unió által használt fogalom, ${ }^{75}$ a terrorizmus finanszírozásának visszaszorításáról szóló egyezmény definíciója ${ }^{76}$ és a Cassesse által meghatározott szokásjogi definíció jelentenek támpontot.

\footnotetext{
${ }^{69}$ Az EBESZ tárgyban született kiadványa rendszerezi és értékeli azokat a nemzetközi egyezményeket, amelyek az ENSZ megalakulását követően születtek. Lásd Status of the Universal Anti-Terrorism Conventions and Protocols as well as other International and Regional Legal Instruments related to Terrorism and Co-operation in Criminal Matters in the OSCE Area. July2018 https://www.osce.org/atu/17138?download=true (letöltés dátuma: 2019. 09. 29.)

${ }^{70}$ Lásd Human Rights, Terrorism and Counter-Terrorism. Fact Sheet No. 32. Office of the United Nations High Commissioner for Human Rights, 2008. https://www.ohchr.org/Documents/Publications/Factsheet32EN.pdf (letöltés dátuma: 2019. 09. 29.)

${ }^{71} \mathrm{http} / /$ www.worldcourts.com/stl/eng/decisions/2011.02.16 Prosecutor v Ayyash.pdf (letöltés dátuma: 2019. 09. 29.)

72 Bővebben lásd Michael P., SCHARF: Special Tribunal for Lebanon Issues Landmark Ruling on Definition of Terrorism and Modes of Participation. In: The American Society of International Law. 2011/6. https:/www.asil.org/insights/volume/15/issue/6/special-tribunal-lebanon-issues-landmark-ruling-definitionterrorism-and (letöltés dátuma: 2019. 09. 29.)

73 A kérdésröl bővebben lásd Alan GREENE: Defining Terrorism: One size fits all? In: International and Comparative Law Quarterly 2017/2. pp. 411-440;; továbbá Alex. P. ScHMID: The Definition of Terrorism. In: The Routledge Handbook of Terrorism Research (ed.) Alex P. SCHMID. Routledge, London - New York, 2011 p. 86 , amelynek eredeti hivatkozott forrása: Report of the High-level Panel on Threats, Challenges and Change. A More Secure World: Our Shared Responsibility. United Nations, New York 2004.

${ }^{74}$ A Büntető Törvénykönyvröl szóló 2012. évi C. törvény 314. §

75 Lásd a terrorizmus elleni küzdelemről szóló 2002. június 13-án kiadott 2002/475/JHA számú Tanácsi kerethatározat 1 . cikkét.

${ }^{76}$ A terrorizmus finanszírozásának visszaszorításáról, New Yorkban az Egyesült Nemzetek Közgyülésének 54. ülésszakán, 1999. december 9-én elfogadott nemzetközi egyezmény 2. cikke (kihirdette a 2002. évi LIX. törvény).
} 


\subsection{A demokrácia, valamint a szubsztantív és a procedurális demokrácia}

Arisztotelész úgy határozta $\operatorname{meg}^{77}$ a demokráciát mint a sokak uralmát, amely magában foglalja az állami vezetők megválasztását és visszahívásának lehetőségét. Egy olyan rendszert, amelyben az egyéni érdekek a többségi, vagyis közérdekhez viszonyítottan kevésbé érvényesülnek, továbbá amely az oligarchia mint a kevesek uralmának ellentéte. Rousseau társadalmi szerződésre és Hobbes protego ergo obligo elvére alapított elmélete ugyanazt a kérdést próbálja megválaszolni, de ellentétes megközelítésből. A meghatározó különbséget az egyén szerepének és helyének a közösségben, az egyén és az állam kapcsolatának, valamint utóbbiból fakadóan a belső szuverenitás korlátainak eltérő megítélése jelenti. Azt mindkét elmélet elismeri, hogy a társadalmi túlnépesedéssel kizárt a kodependens viszonyoktól való eltérés, ugyanakkor az együttmüködéssel járó önkorlátozás alapját eltérően határozzák meg. Az Egyesült Államok Alkotmánya (1787) és Az ember és a polgár jogainak deklarációja (1789) is Rousseau elméletét vette át. Löwenstein erre is tekintettel sorolta saját felosztásában az eredeti alkotmányok körébe az Egyesült Államok Alkotmányát. ${ }^{78}$ James Madison a kormányzás és a képviselet szempontjából megkülönböztette a demokráciát és a köztársaságot. A demokrácia szerinte az emberek közvetlen részvétele a közpolitika meghatározásában és a döntéshozatalban, míg a köztársaságban mindezt a társadalom tagjai nem közvetlenül, hanem választott képviselőik útján teszik. Madison, az Egyesült Államok egyik alapító atyja és egyben negyedik elnöke természetesen a képviseleti úton gyakorolt közhatalmat részesítette előnyben, mivel a választott képviselök eleve kétszeresen szelektált körből kerülnek ki, akik ezért statisztikailag nagyobb eséllyel lesznek a megfelelő személyek a feladatra ${ }^{79}$ Ez a megfontolás önmagában erős legitimációt alapoz meg az állami vezetőknek, akik választás útján nyerik el tisztségüket. Azonban ez kétélű fegyver, minthogy a népszerüség alakulására hivatkozva az ellenzék megkérdőjelezheti a választott vezető legitimitását, és így döntéseit is, illetve a népszerüség megtartása és növelése nagy eséllyel fog hangsúlyosabb figyelmet kapni a politikustól, mint maga a kormányzás. John Stuart Mill a Madison által tett megkülönböztetést pragmatikusan összevonta és az előnyöket kiemelve a képviseleti demokráciát jelölte meg a politikai egyenlőség esszenciájának. ${ }^{80} \mathrm{~A}$ képviseletben megvalósuló politikai egyenjogúság

\footnotetext{
77 AriszTOTELÉsz: Politika. (ford. SzABÓ Miklós) Gondolat, Budapest 1994. pp. 317

${ }^{78}$ Karl, Loewenstein: Constitutions and Constitutional Law in the West and in the East. In: The Indian Journal of Political Science 1969/3., pp. 203-248.

79 Robert William, SHOEMAKER: „Democracy” and „Republic” as Understood in Late Eighteenth-Century America. In: American Speech 1966/2., pp. 83-95.

80 John Stuart, Mill: Representative Government. 1861. (Reprint: Batoche Books, Kitchener, 2001.), p. 32. https://socialsciences.mcmaster.ca/econ/ugcm/31l3/mill/repgovt.pdf (letöltés dátuma: 2019. 09. 29.)
} 
ígérete nem más, mint a demokrácia alapvető igazsága. Madison és Mill egyaránt rávilágítanak arra, hogy egy nagy lélekszámú társadalomban törvényszerü, hogy a hatalomgyakorlásban csak képviseleti úton, vagyis közvetetten lehet részt venni. Másrészt, a politikai vezetőknek észre kell venniük a közérdeket, a közakaratot és a közjót.

Robert Dahl szerint ${ }^{81}$ vannak jó és rossz hatások a demokráciára mint az állam politikai berendezkedésére, amelyeket az adott állam közhatalmi megalapozottságának történelmi háttere, a gazdaság- és a társadalomirányításhoz kapcsolódó döntéshozatal jellege, az állam fejlettségi állapota, a társadalom kulturális sokszínüsége és tagjainak egyenlősége, az államra irányuló külső hatásgyakorlás mértéke, végül az állami vezetők személyes értékrendje befolyásol és határoz meg. Ezek a jellemzők árnyaltan, összefüggően és egymásra hatással, de semmiképpen sem kizárólagosan érvényesülnek. Dahl szerint fontosabb egy demokrácia stabilitását tekintve, ha a kormányzásért folytatott politikai verseny megelözi a politikai struktúra létrehozását. Véleményét alátámasztja, hogy azokban az államokban, amelyek a gyarmati létből rögtön egy európai típusú liberális politikai rendszert adoptáltak, nagyobb eséllyel alakulnak ki erős katonai vagy rendőrállamok, illetve a puccsok száma jóval gyakoribb, mint a mintaadó államokban.

Dahl amellett érvel, hogy a demokráciát tovább stabilizálja, ha a gazdasági és szociális kérdéseket pluralizáltan határozzák meg, nem pedig egy centralizált központból. Teszi mindezt az Egyesült Államokban, ahol éppen a gazdasági és szociális kérdések tekintetében élveznek jelentős önállóságot a tagállamok a szövetségi kormánnyal és törvényhozással szemben. Hasonlóan érvelhetünk az Európai Unió tagállamában, ahol a szubszidiaritás elvét az eurobürokrácia útvesztőinek adekvát korlátozására használjuk szinonimaként. Ugyanakkor kizárólagosan és véglegesen nem jelenthetjük ki, hogy a centralizált döntéshozatal káros lenne a demokráciára. Nem elhanyagolható szempont az állam területének vagy lakosságának mérete, vagy történelmi hagyományai. Németország, az Egyesült Államok, India, Brazília méretük és történelmi hagyományaik miatt decentralizáltan müködnek. Az Egyesült Királyság és Franciaország közötti területi és lakosságszámbeli különbség nem számottevő, ugyanakkor Franciaország az unitárius, centralizált központi közigazgatás mintaadója, míg az Egyesült Királyság rendkívül bonyolult politikai és igazgatási rendszerét a tradíció határozza meg. Egy

${ }^{81}$ Robert, DAHL: On Democracy. Yale University Press, 2000. (a továbbiakban: DAHL), p. 224. 
kis vagy közepes méretű állam esetében a pluralizált döntéshozatal jelentős mértékü hátrányt okozhat az állam versenyképessége szempontjából, ezért tipikusan a centralizációt választják.

A fejlett államok Dahl szerint nagyobb eséllyel tudnak ellenállni az olyan mértékü belső feszültségeknek, amelyek veszélyeztetik az állam társadalmi és gazdasági rendjét, alapvető politikai struktúráját. Fontos, de nem kizárólagosan meghatározó elemei az állam működésének a fegyveres erők. A fejlődő államokban ezzel szemben a hadsereg és a rendvédelmi szervek szerepe jelentősen felértékelt, amely abból fakad, hogy a központi kormányzat hatalmának sokszor egyetlen - támaszát jelentik. Állományuk társadalmi helyzete privilegizált más foglalkozásokhoz képest, amely a rendszeres fizetésekben és a tervezhető nyugellátásban nyilvánul meg. A hadsereg emiatt rendkívül lojális a központi hatalomhoz. Értelemszerüen egy fejlett állam, nemcsak gazdaságilag stabilabb fejlődő társaihoz képest, de társadalma is kellően képzett, nyitott és így politikailag aktív. Érdekes ugyanakkor, hogy Dahl rendkívül pragmatikusan szembesít azzal a ténnyel, hogy egy kulturálisan homogén államnak mindig erősebbek a demokratikus intézményei, mint egy heterogén államnak. Egyszerüen azért, mert az államot alapból feszítő külső erőket ${ }^{82}$ jelentős mértékben enyhíti a társadalmi stabilitás, ami a homogén társadalmakra inkább jellemző. A társadalom integritását erősíti továbbá a társadalmi egyenlőség, amely szintén jó a demokrácia számára. Ellenben a külső befolyás, legyen az bármily’ magasztos célból, a demokráciát minden esetben gyengítik, hiszen károsan befolyásolják a politikai versenyt. A demokráciában a közhatalmat alapvetően választott képviselők gyakorolják vagy ellenőrzik a közhatalom gyakorlását, azonban egy külső befolyás valójában nem elszámoltatható, illetve demokratikus legitimációja megkérdőjelezhető. Ez végső soron relativizálja a társadalom hagyományos politikai értékeit. Végül mindehhez csatlakozik a választott állami vezetők személyes értékrendje, amely szerint a demokrácia és a politikai verseny egyaránt lehet jó, amely az együttmüködésen és a kölcsönös engedményeken nyugszik. Ennek ellentéte a teljes és kizárólagos politikai pragmatizmus, amely ellehetetleníti a hagyományos demokratikus értékeket, s csupán a szükségszerü politikai versenyre összpontosít.

\footnotetext{
82 Richard, Hartshorne: Political Geography in the Modern World. In: The Journal of Conflict Resolution 1960/1., pp. 52-66.
} 
A demokrácia jelentéstartalmát folyamatos vita övezi Gallie szerint, ${ }^{83}$ mivel a nélkülözhetetlen elemeket rendszerint olyan kiegészítésekkel, magyarázatokkal vagy interpretációkkal egészítik ki, amelyek már a normatív leírás mellett morális megfontolásokat is tartalmaznak. Ezek sokszor inkább vágyak vagy elvárások a közhatalom gyakorlóival szemben. A demokrácia alapja vitathatatlanul a politikai egyenlőség, amely egyszerre összeköti és egymás mellé rendeli a választójoggal rendelkezőket. A demokrácia kevert - egyszerre normatív és morális értékelésekor azonban összemosódnak az egyenlőség fogalmáról kialakított absztrakt vezérelvek és az institúcionális értékelések. ${ }^{84}$ Schumpeter úgy határozta meg a demokráciát, mint a közjó elérésére kialakított intézményrendszer, amelyet megválasztott képviselők müködése határoz meg. ${ }^{85}$ Beitz szerint ${ }^{86}$ három módszer segíthet eldönteni a demokrácia politikai értékét: (1) a demokrácia csak egy eljárás, (2) a demokráciával a közösség által együtt elérhető legjobbra számíthatunk, (3) a többségi akarat szerinti politikai folyamatokat írja le. Mindegyik koncepció az egyenlőség fogalmának egyfajta leírása. A procedurális megközelítés a közös politikai döntéshozatalban való részvétel jogára fókuszál. Ilyen formán nem releváns, hogy mi lesz maga a döntés. A fontos, hogy a döntés meghatározott eljárás szerint szülessen meg, amely így formálisan megalapozza és erősíti a demokráciát. A második, valamennyi állampolgár közös morális státuszát alapozza meg a politikai döntésekre hivatkozva. Ebben az értelemben a döntéshozatali eljárástól függetlenül létezik az önmagában való érték. Ez az érték azonban nem a demokrácia sajátja, hanem maga az érték határozza meg a demokráciát azzal, hogy elérhetőségével kecsegtet és teszi vonzóvá azt a politikai rendszert, amelyet demokráciának nevezünk. Ebből a megközelítésből nézve a demokrácia, mint politikai döntéshozatal csupán eszköz az értékek eléréséhez. Ebbe a körbe sorolható néhány olyan elmélet is, amelyek alapvetően más indíttatásúak. A társadalomban vágyott szociális egyenlőség, amelyet Rawls igazságosság elméletében határozott meg, ${ }^{87}$ valamint Habermas azon megállapítása, miszerint a politikai elit felfedezi majd alkalmazza, hogy mi is az igazság. ${ }^{88}$ A harmadik az állampolgár döntéshez kapcsolódó politikai súlyára helyezi a hangsúlyt. Ehhez azonban szükséges, hogy a politikai közösség képes legyen racionális döntést hozni. Ennek

\footnotetext{
${ }^{83}$ Walter Bryce, GALLIE: Essentially contested concepts. In: Proceedings of the Aristotelian Society 1955/56., pp. 167-198.

${ }^{84}$ Charles, BeITz: Political equality. An Essay in Democratic Theory. Princeton University Press, Princeton 1989. (a továbbiakban: BEITZ), p. 6.

${ }^{85}$ Joseph, SCHUMPETER: Capitalism, Socialism and Democracy. Allen \& Unwin, London 1952., p. 250

${ }^{86}$ BEITZ, p. 20.

${ }^{87}$ John, RAWLS: A Theory of Justice. Harvard University Press, Cambridge, Massachusetts 1980., pp. $216-221$.

${ }^{88}$ Jürgen, HABERMAS: Theorie des kommunikativen Handelns 1981.; DRYZEK, John S.: Discursive Democracy. Cambridge University Press, Cambridge 1994.
} 
érvényesülését Arrow feltételhez kötötten ${ }^{89}$ látja megvalósíthatónak, így megkérdőjelezhető gyakorlati kivitelezhetősége.

A demokrácia meghatározásakor a gondolkodók jelentős része a politikai rendszer strukturális elemeire összpontosít, ${ }^{90}$ mint szabad választások tartása, a kormányzat parlamenti ellenőrzöttsége, a bíróságok befolyásmentes müködése stb. Kézenfekvőnek tünik, hogy intézmények feladat- és hatáskörét, valamint demokratikus értékeket és célokat állítsunk szembe egymással. A szubsztantív és a procedurális demokrácia ugyanakkor nem két látványosan elkülönülő értelmezési dimenzió, hanem értelmezésére valójában egymás függvényében nyílik teljes mértékig lehetőség. Hasonlóan a demokratikus intézmények és a demokratikus eszmék megjelenése és terjedése sem független a nemzetközi kapcsolatoktól ${ }^{91}$ és a metajurisztikus elemek befolyásától. Az intézmények önmagukban kevesek, hiszen szerepük a politika végrehajtásában, illetve az érvényre juttatásában merül ki. A politikai síkon definiált eszmék viszont csak az apparátus közreműködésével válnak valósággá.

Egyes arab államokban 2006 és 2008 között végzett kutatásra ${ }^{92}$ alapítva David Doherty és Jessica Mecellem azt vizsgálta, ${ }^{93}$ hogy az emberek a demokrácia szubsztantív vagy a procedurális értelmezését tartják fontosabbnak. Arra voltak kíváncsiak, hogy ha egy jellemzőt kellene választani, amely leginkább a demokrácia sajátja, akkor az melyik lenne a következők közül: 1.) annak lehetősége, hogy szabad választások alkalmával megváltoztassa a kormányt (választások); 2.) a kormányzat vagy a közhatalmat gyakorlók szabad bírálata (véleményszabadság); 3.) a tehetősebbek és a szegényebbek közötti minimális jövedelmi rés (jövedelmi egyenlőség); és végül 4.) alapvető szükségletek - úgy mint élelmiszer, ruházat, szállás - kielégítése mindenki számára (alapvető szükségletek). Az értékelésnél a szabad választás és a véleményszabadság a procedurális demokrácia, míg a jövedelmi egyenlőség és az alapvető szükségletek a szubsztantív fogalmának elfogadottságát feltételezték. Bár vitatható, hogy a demokrácia szubsztantív fogalmát ezekkel a fogalmakkal ki lehetne meríteni. Az

\footnotetext{
${ }^{89}$ Kenneth, ArRow: Social Choice and Individual Values. Yale University Press, New Haven 1963., p. 4.

90 Thomas Martin, FRANCK: The Emerging Right to Democratic Governance. In: The American Journal of International Law 1992/1., pp. 46-91.

${ }^{91}$ Mary Henrietta, KALDOR: Democracy and globalisation. In: Working paper series. Centre for the Study of Global Governance, London School of Economics and Political Science 2008/3., p. 34. https://www.files.ethz.ch/isn/94335/WP03.pdf (letöltés dátuma: 2019. 09. 29.)

${ }_{92}$ Arab Barometer Survey (2006-2008) http://www.arabbarometer.org (letöltés dátuma: 2019. 09. 29.)

${ }^{93}$ David, Doherty, Jessica, Mecellem: Procedural and Substantive of Democracy in Four Arab Populations. (a továbbiakban: DOHERTY-MECELLEM), p. 13.

https://pol.illinoisstate.edu/downloads/conferences/2012/3A_MECELLEMConceptions\%20of\%20Democracy.p df (letöltés dátuma: letöltés dátuma: 2019. 09. 29.)
} 
említett kutatás szempontjából azért lehet mégis más értéke a jövedelmi egyenlőségnek és az alapvető szükségleteknek, mert a vizsgált társadalmak vallási hagyományai (iszlám) és politikai rendszereik történeti előzményei (szocialista vagy szocialista jegyeket viselő államok) egyaránt ezeket az értékeket teszik hangsúlyossá. Kétséges, hogy ugyanezen fogalmak használata egy kutatás során azonos tartalmat nyerne és hasonló megítélés alá esne egy nyugat-európai államban vagy az Egyesült Államokban. Érdekes kiegészítő - de biztosan nem konkluzív eredménye a kutatásnak, hogy a vizsgált társadalmakban a nők jellemzően szívesebben választják a demokrácia szubsztantív megközelítését, szemben a férfiakkal, akik inkább a procedurális megközelítést preferálják. ${ }^{94}$

A demokrácia procedurális értelmezése szerint a demokrácia nem más, mint intézmények, szabályok, valamint a kormányzás és a részvétel gyakorlatának összessége. A megközelítés szerint a kormányzásban résztvevők közötti viszonyrendszer, a döntéshozatal folyamata és a közhatalomért folytatott verseny tényszerü leírása elégséges leírása a demokráciának és megfelelő képet mutat arról, hogy a demokrácia az-e, aminek mondja magát, illetve funkcionále ${ }^{95}$ Ebben az értelemben a döntéshozatal folyamata és az ezt meghatározó szabályok nagyobb hangsúlyt kapnak, mint maguk a döntések, illetve a döntés tényleges tartalma. ${ }^{96}$ Azok a vezérelvek, amelyek definiálják a procedurális demokráciát végső soron arról szólnak, hogy a döntéshozatal milyen módon történjen? Vagyis arra kell válaszolni, hogy 1.) ki vegyen részt a döntéshozatalban; 2.) a résztvevők szavazata hogyan aránylik egymáshoz; 3.) mekkora arány kell a döntéshez; s végül 4.) a döntéshozók legyenek tekintettel a társadalom többségének akaratára. ${ }^{97} \mathrm{Az}$ első három vezérelv önmagában csak a közvetlen demokrácia esetében alkalmazható, ezért mindenképpen szükség van a negyedik komponensre is. Janda szerint ${ }^{98}$ az Egyesült Államok alkotmányában a government by the people kifejezés szorosan összefügg a procedurális demokrácia fogalmával. ${ }^{99}$ Ebből következik, hogy az eljárás formalitásának megfelelve (pl. többségi álláspont, megfelelő döntési arány stb.) igazságtalanságok és a demokrácia alapértékeivel egyébként összeegyeztethetetlen tartalommal és céllal rendelkező döntések születhetnek. Nem beszélve arról, hogy azon társadalmi csoportok álláspontját,

\footnotetext{
${ }^{94}$ DOHERTY-Mecellem, p. 16.

${ }^{95}$ Kenneth, JANDA, Jeffrey M., BERry, Jerry, Goldman, Deborah, SHILDKRAUT: The Challenge of Democracy. American Government in Global Politics. Twelfth Edition. Cengage Learning 2013. (a továbbiakban: JANDABERRY-GOLDMAN-SHILDKRAUT), p. 33.

96 Gregory, BERry: Why Procedural Due Process is Essential to the Functioning of a Free Society. Howard University 2002.

${ }^{97}$ JANDA-BERRY-GOLDMAN-SHILDKRAUT, p. 33.

${ }^{98}$ JANDA-BERRY-GOLDMAN-SHILDKRAUT, p. 39.

${ }^{99}$ Magyarország Alaptörvényében ezt a B) cikk (3) bekezdése szolgálja.
} 
amelyek nem rendelkeznek hatékony (megszervezett) képviselettel, egyszerüen nem veszik figyelembe a döntéshozatal során. A döntés legalitását ez nem is érinti, hiszen azon érdeket nem kell (lehet?) figyelembe venni, amely formálisan nem része a döntéshozatali eljárásnak.

A demokrácia szubsztantív értelmezésekor a politikai és jogi döntéshozatali rendszert a méltányosság, a jogegyenlőség és az igazságosság érvényesülésének mércéjével jellemezzük. Ebben az esetben nem a döntéshozatal folyamata van az értékelés fókuszában, hanem maga a döntés. Vagyis maga az eljárás végeredménye. A szubsztantív értékelés támogatói azzal érvelnek, hogy a társadalomban olyan mélyen gyökerező strukturális egyenlőtlenségek és ezeket tartósító normatív megkülönböztetések vannak, amelyet a procedurális demokrácia döntéshozatalában való puszta részvétel nem képes áthidalni. Ezért szükséges, hogy a hiányosságok ellensúlyozása a kormánypolitikában jelenjen meg. ${ }^{100}$ Azt azonban általában kijelenthetjük, hogy a szubsztantív demokrácia elsőségét hirdetők célszerüségi okokból megtartanák a procedurális demokrácia formalitását és mechanikáját. ${ }^{101}$ Sokat sejtető, hogy a szubsztantív demokrácia tartalmi vizsgálatakor a véleménynyilvánítás szabadságát egyesek a procedurális demokráciát meghatározó elemek közé, ${ }^{102}$ mások a szubsztantív elemek közé sorolják. ${ }^{103}$ A szubsztantív demokrácia legfontosabb kritikája ${ }^{104}$ az, hogy nem határozza meg pontosan, milyen konkrét elemekkel kell rendelkeznie egy politikai struktúrának ahhoz, hogy demokráciának titulálhassa magát. Egy kötött eljárásrend nélkül az érintettek, vagyis a döntéshozók és a döntés alanyai folyamatos nézeteltérésben lesznek afelől, hogy a döntés valójában megfelel-e a demokratikus értékeknek. A szubsztantív demokrácia egyik kulcskérdése éppen ezért a szociális-gazdasági alapjogok tekintetében az állam biztosítási kötelezettsége vagy jóval gyengébb promótálási kötelezettsége. ${ }^{105}$

Mindezek alapján mondja azt Dahl, hogy a két megközelítés éles elválasztását és szembeállítását el kell hagynunk ahhoz, hogy megtaláljuk a demokrácia tényleges értékmérőjét. Dahl a két megközelítés közös pontjait javasolja inkább előtérbe helyezni és a két szempontrendszert egyszerre alkalmazni. ${ }^{106}$ Lundquist mindezt kiegészíti azzal a

\footnotetext{
100 James E., Bell, Lynn A., STAEHELI: Discourses of diffusion and democratization. In: Political Geography 2001/2. (a továbbiakban: BELL-STAEHELI), p. 175.

${ }^{101}$ Bell-Staeheli, p. 175., JANDA-BERRY-GOLDMAN-SHILDKRAUT, p. 33.

102 DOHERTY-MECELLEM, p. 5.

103 JANDA-BERRY-GOLDMAN-SHILDKRAUT, p. 33.

${ }^{104}$ JANDA-BERRY-GOLDMAN-SHILDKRAUT, p. 38.

105 BELL-STAEHELI, p. 175.

${ }^{106}$ DAHL, p. 153., 160., 272., 467.
} 
problémafelvetéssel, hogy a szubsztantív és a procedurális demokrácia esetében egyaránt válságot okoz a legitimáció hiánya, amely egyértelmủen az államba vetett állampolgári bizalom megvonását fogja jelenteni, illetve rövid úton hatalmi válsághoz vezet. Az állampolgárok ugyanis nem fogadják el még a szabályszerű döntést sem, ha az elfogadhatatlan eredményre vezet. Ugyancsak nem türik el azt, ha a jó cél érdekében felejtik el a közhatalom gyakorlói a szabálykövetést az eljárásaik során. ${ }^{107}$ Ezért arra a megállapításra jut Lundqvist, hogy a legitimációhoz egyszerre kell a szubsztantív és a procedurális feltételeknek teljesülniük. Habermas ezt a logikát alkalmazza, amikor a formális (procedurális) és a társadalmi legitimációt a megkülönböztetés szükségességének felismerésével egyidejüleg kodependens viszonyukra rámutat. A legitimáció két dimenziója ugyanis hat egymásra, erősíti egymást, és nem egymástól függetlenül, párhuzamosan létezik. ${ }^{108} \mathrm{Az}$ összefüggéseik ellenére a szubsztantív és a procedurális demokráciát két külön létező politikai valóságnak érezhetjük. Egymásnak alternatívájának, amelyek szinte kizárják a másik igazságát, politikai megalapozottságát. Föleg akkor, ha szembe kerül egymással két olyan alapvetö, egyszerü politikai döntés, amelyek a gyakorlatban különösen megosztók tudnak lenni. Minden embernek meg kell védeni az alapvető jogait (szubsztantív). Ezt kevesen és nem túl nagy sikerrel tudják vitatni. Ahogy azt sem lehet kikezdeni, hogy a politikai többségnek joga van bármilyen döntést hozni, amely valamilyen irányba elmozdítja a társadalmat (procedurális). A jogi értelemben vett egyenlőség (szubsztantív) láthatóan könnyen konfliktusba kerülhet a különféle szabadságjogokkal (procedurális), holott nem vitatható a fontosságuk egy demokratikus állam értékelésekor. ${ }^{109}$

Felmerül továbbá a kérdés, hogy fontosabb-e a politikai rendszer stabilitása (szubsztantív) vagy, ha lehetőség mutatkozik rá, biztosítsuk az egyén számára a teljes körü - politikai önkifejezés szabadságát (procedurális)? ${ }^{110}$ Mindez különösen akkor kap hangsúlyos szerepet, ha a politikai társadalom etnikai vagy vallási értelemben véve (is) heterogén és a politikai többség demokratikus akarata természetszerüleg kihatással van a kisebbségre is, amely osztozik a többség jogi és politikai valóságán. Az egyének politikai helyzetére fókuszáló institucionális megközelítésben a kisebbségvédelem a legfontosabb intézmény, amely segíthet a vizsgált

\footnotetext{
${ }^{107}$ Lennart, LuNDQvisT: Förvaltning och demokrati. Norstedts juridikförl (Lund: Studentlitteratur), 1991. (a továbbiakban: LUNDQVIST), p. 68.

${ }_{108}$ Raymond, PLANT: Jürgen Habermas and the idea of legitimation crisis. In: European Journal of Political Research 1982/4., pp. 341-352.

${ }^{109}$ LUNDQVIST, p. 67.

${ }^{110}$ Crawford Brough, MACPHERSON: Democratic theory: Essays in retrieval. Oxford University Press, 1973., p. 51., idézte: LUNDQVIST, p. 69.
} 
demokrácia értékelésében. ${ }^{111}$ A politikai rendszerek törékenységét mutatja, hogy a demokrácia, amely eredetileg nem más, mint az egyszerü többség elve, könnyen vezethet igazságtalansághoz a kisebbségbe kerültek számára. ${ }^{112}$ Erre elégséges megoldásnak tűnhet a minősített többséghez kötött döntéshozatal bevezetése, ugyanakkor ez felértékeli a kisebbségek politikai szerepét és könnyen eredményezhet kisebbségi uralmat ${ }^{113}$ vagy döntésképtelenséget. A demokratikus politikai valóság szubsztantív oldala által kínált vezérelvek azok, amelyek elsődlegesen lehetővé teszik egy-egy konkrét politikai döntés megszületését. Az állampolgárok döntéshez kötődő (eljárási) jogait formalizált keretek között szükséges meghatározni, amely ugyanannak a politikai valóságnak a procedurális oldala lesz. Ugyanakkor egyik jelleg sem válhat kizárólagosan dominánssá. Különösen a demokrácia procedurális vonatkozásai nem létezhetnek önmagukért, hiszen ezzel teljes mértékig kiüresítenék és végső soron hatástalanítanák a közhatalom korlátozására és ellenőrzésére tett valamennyi próbálkozást.

\footnotetext{
${ }^{111}$ LUNDQVIST, p. 70.

112 JANDA-BERRY-GOLDMAN-SHILDKRAUT, p. 39.

113 JANDA-BERRY-GOLDMAN-SHILDKRAUT, p. 33.
} 


\subsection{A terrorizmus hatásának komplexitása}

A terrorizmus szinte minden területen kifejti hatását, mind az egyén, mind a közösség (állam és társadalom egyaránt) érzékelheti. A megváltozott körülmények, amelyeket a terrorizmus határoz meg, egyfajta alkalmazkodási kényszert jelentenek minden érintett számára. Az erre adott reakciók jobb belátásból önkéntesek vagy elkerülhetetlen kötelezők lehetnek. Az állam elsődleges célja, hogy a természetes személyek életét, testi épségét és vagyonát, a közvagyont, valamint saját müködőképességét megőrizze. A terrorizmus elleni fellépés klasszikusnak tekinthető közvetlen hatásterületei: a közlekedés, a határátlépés, a közműszolgáltató rendszerek, valamint az állami intézmények zavartalanságának biztosítása. A terrorizmus elleni védekezésre fókuszáló nemzeti stratégiák, illetve a nemzetközi együttmüködési rendszerek ezeket jelölik meg az erőforrásgazdálkodás elsődleges irányvonalaiként. Mások kiemelt célpont jellegük miatt az állami tisztviselőket is ide sorolják. ${ }^{114}$

Egyes ágazatok és állami alrendszerek, mint az oktatás, ${ }^{115}$ az egészségügy, a turizmus ${ }^{116}$ és a sajtó ${ }^{117}$ a terrorveszélynek való közvetlen kitettségük miatt sokszor önként alávetik magukat egy sor biztonsági szabálynak, ${ }^{118}$ mindamellett a jogalkotó is törekszik arra, hogy jogilag meghatározza a biztonság minimumát. ${ }^{119}$ A terrorizmus közép- és hosszú távon is kifejti hatását. Miután elmúlik a terrorcselekményt közvetlenül követő bénultság, a jogi, ${ }^{120}$ politikai,

\footnotetext{
114 A FÁK-országok által a terrorizmus elleni küzdelemben való együttmüködésről szóló 1999-es egyezmény a kiemelten védendő lehetséges célpontok között említi az állami tisztviselőket. https://treaties.un.org/doc/db/Terrorism/csi-english.pdf (letöltés: dátuma: 2019. 09. 29.)

${ }^{115}$ Lásd a toulouse-i Ozar Hatorah zsidó iskola elleni 2012-es támadást.

${ }^{116}$ Bevett gyakorlat, hogy a külügyminisztériumok tájékoztatják a lakosságot a népszerü turisztikai desztinációkra jellemző aktuális terrorveszélyről, ahová így mindenki saját felelősségére utazhat. Értelemszerüen ez az állam saját állampolgáraira vonatkozó védelmi kötelezettségét nem csökkenti, de az utazókat terhelő a biztosítási díjakra minden bizonnyal kihatással van.

${ }^{117}$ Lásd a Jylland-Posten újságíróinak szánt fenyegetéseket és a Charlie Hebdo elleni támadást.

118 Zdeněk, KalVACH: Basics of soft targets protection. Guidlines. Soft Targets Protection Institute. Prague, June 2016 ,

https://www.google.com/url?sa=t\&rct=i\&q=\&esrc=s\&source=web\&cd=2\&ved=2ahUKEwjatfCIoIDmAhUQlIs KHXgwBDMQFjABegQIRRAC\&url=https\%3A\%2F\%2Fwww.mvcr.cz\%2Fcthh\%2Fsoubor\%2Fbasics-of-softtarget-protection-guidelines.aspx\&usg=AOvVaw1Fl22iF0fseDL16i-EZ4kG (letöltés dátuma: 2019. 09. 29.)

119 The protection of critical infrastructures against terrorist attacks: Compendium of good practices. UNOCT, CTED, Interpol, 2018.

https://www.un.org/sc/ctc/wp-content/uploads/2019/01/Compendium of Good Practices Compressed.pdf (letöltés dátuma: 2019. 09. 29.)

${ }^{120}$ Franciaországban a kormány kezdeményezésére készült egy hatástanulmány a civil biztonsági cégek munkavállalóinak a maroklőfegyverrel és gépkarabéllyal történő felfegyverzéséről.

https://www.gouvernement.fr/sites/default/files/document/document/2018/09/rapport de mme alice thourot et $\mathrm{m}$. jean-michel fauvergue deputes - dun continuum de securite vers une securite globale -

11.09.2018.pdf (letöltés dátuma: 2019. 09.29.)
} 


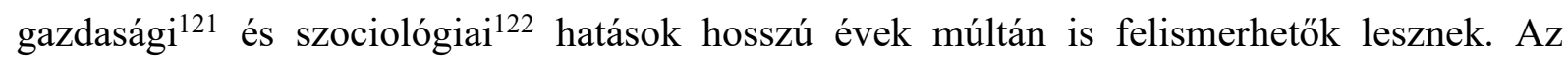
infokommunikációs technológiai fejlesztések, valamint a szolgáltatók és a felhasználók kapcsolatát is - úgy tünik - véglegesen megváltoztatta a terrorizmus. ${ }^{123}$ Az közismert, hogy nem jelent megoldást a bünözés felszámolására - és vélhetően a terroristák feltartóztatására sem -, ha minden sarokra rendőrt állít az állam. Értelemszerüen ez nem is valósítható meg. A közbiztonsági szervek képességeit kiegészíthetik a potenciális célpontok környékén üzemelö zárthálózatú térfigyelő kamerarendszerek, amelyek London esetében már a félmilliós darabszámot is elérik. ${ }^{124}$ A civil lakosság életének megfigyelése, különösen egy urbanizált környezetben ma már szinte természetesnek hat.

A 2016-os nizzai gázolásos merényletet követte decemberben a berlini, majd 2017-ben a barcelonai támadás. Mindezek hatására a városi tömegrendezvényeket a közbiztonságért felelős szervek betontömbökkel védik, míg a sétálóutcákkal tarkított belvárosi részeket véglegesen, fizikai akadályokkal tervezik elzárni a gépjármüforgalom elől. ${ }^{125}$ Esetleg forgalomlassító útszükületeket helyeznek el a terrorveszélynek jobban kitett lehetséges célpontok közúti megközelítési pontjaira. ${ }^{126}$ A franciaországi terrorhullám ideje alatt tapasztalható volt, hogy a

${ }^{121}$ Dominique, Vanneste, Petronella, Tudorache, Flavia, TeOdoroiu, Thérése, STEEnBERGHen: The impact of the 2016 terrorist attacks in Brussels on tourism. In: Belgeo. $2017 / 4$. https://journals.openedition.org/belgeo/20688\#text (letöltés dátuma: 2019. 09. 29.)

${ }^{122}$ Gunn Elisabeth, Birkelund, Tak Wing, Chan, Elisabeth, UGreninov, Arnfinn H., MidTBøEN, Jon, RogSTAD: Do terrorist attacks affect ethnic discrimination in the labour market? Evidence from two randomized field experiments. In: The British Journal of Sociology 2019/1., pp. 241-260.

${ }^{123}$ First report of the observatory function on encryption. Europol EC3 European Cybercrime Centre, Hága, 11. January 2019

http://www.eurojust.europa.eu/doclibrary/Eurojust-

framework/Casework/First $\% 20$ report $\% 20$ of $\% 20$ the $\% 20$ observatory $\% 20$ function $\% 20$ on $\% 20$ encryption $\% 20$ (join t \%20Europol-Eurojust \%20report\%20-\%20January\%202019)/2019-01_Joint-EP-EJ-Report_Observatory-

Function-on-Encryption_EN.pdf (letöltés dátuma: 2019. 09. 29.)

${ }^{124}$ A félmilliós darabszámot a Home Office által megrendelt kutatásból vonják le következtetésként, amely összességében 4,2 milliós darabszámról beszél az Egyesült Királyság egész területére nézve. A magas szám úgy jön ki, hogy a hatóságok a lakossági térfigyelö kamerák hálózatára is képesek rácsatlakozni. Ezt technikai elöfeltételként határozzák meg.

https://assets.publishing.service.gov.uk/government/uploads/system/uploads/attachment data/file/378449/09-05UK-Police-Requireme22835.pdf (letöltés dátuma: 2019. 09. 29.)

${ }^{125}$ A gázolásos merényleteket azonos eredményességgel képes megelőzni egy rendőrség feliratú betonelem, egy köztéri szobor vagy egy szökőkút. Azonban az emberek félelemérzete tartósítható azzal, ha szüntelenül emlékeztetik öket a veszélyre. Célszerü lehet olyan megoldást találni ezért, amely egyszerre véd és megnyugtat.

${ }^{126}$ Barcelonában a városi élet és a közlekedés reformjára 2013 óta folyik egy tervező munka, amelyet Superblock névvel illetnek. A városvezetés törekvéseinek szükségességét igazolta a 2017. augusztus 17-én Barcelona egyik sétálóutcájában elkövetett gázolásos merénylet.

https://www.google.com/url?sa=t\&rct=j\&q=\&esrc=s\&source=web\&cd=29\&ved=2ahUKEwiknYLboMnkAhXp 1YsKHVQ1B-

YQFjAcegQIRhAC\&url=http $\% 3 \mathrm{~A} \% 2 \mathrm{~F} \% 2 \mathrm{Fwww}$. sustainablecities.eu $\% 2$ Ffileadmin $\% 2 \mathrm{Ftemplates} \% 2 \mathrm{Fesc} \% 2 \mathrm{Fli}$ b\%2Ftransformative actions $\% 2 \mathrm{~F} \% 2 \mathrm{~F}$ utility $\% 2$ Ftools $\% 2$ Fpush resource file.php $\% 3 \mathrm{Fuid} \% 3 \mathrm{Ddd} 9 \mathrm{bf} 772 \&$ usg= AOvVaw1 jwT7LxdCgqppTKW- jNU (letöltés dátuma: 2019. 09. 29.); 
tömegközlekedés szempontjából jelentős csomópontokon, valamint a - a Schengeni egyezmény miatt szabadon átjárható - határátkelő helyeken ideiglenes ellenőrző-áteresztő pontokat állítottak fel a hatóságok. Urbanizált környezetben később lehetőség kínálkozott arra, hogy az ideiglenes forgalmi tereléssel, illetve a rendezvényen résztvevő gyalogosokat védő betontömbökkel alakított forgalmi rendet végül a közlekedéstechnikai fejlesztés ${ }^{127}$ későbbi ütemezésekor véglegesítsék. A terrorizmus hatására tehát átalakultak a településrendezési szabályok is. Olyan elképzelések is napvilágot láttak, amelyek szerint a településmagokból számüzni kellene azokat a gépjármütípusokat, amelyeket könnyü hozzáférhetőségük, irányíthatóságuk, illetve a hatóságok figyelmét elkerülő jellegük miatt a magányos farkas terroristák más gépjárművekkel szemben előnyben részesítenek. ${ }^{128}$

A terrorizmus hatásainak összetettségéből és a hosszútávon is müködőképesnek látszó megoldásokból is látszik, hogy önmagában a hatósági intézkedések kevésnek bizonyulnának. Elengedhetetlen, hogy a szükséges politikák, az állami szervezetrendszer, a jogrendszer és általában a szemléletmód adaptálódjanak a megváltozott környezethez, amelyet a nemzetközi terrorizmus jelent.

https://www.vox.com/energy-and-environment/2019/4/8/18273893/barcelona-spain-urban-planning-cars (letöltés dátuma: 2019. 09. 29.)

${ }^{127}$ Bátran ide sorolhatjuk a városi és közúti forgalmat támogató mesterséges intelligencia, az önvezető autók és a lakosságot veszély esetén automatikusan figyelmeztető rendszerek fejlesztését.

${ }^{128} \mathrm{https} / / /$ www.g4s.com/en-us//media/g4s/usa/files/whitepapers/vehicular terrorism the threat behind the wheel.ashx (letöltés dátuma: 2019. 09. 29.) 


\section{A FÉLELEM JOGRENDSZERI LECSAPÓDÁSAI}

A félelem olyan tudatállapotot befolyásoló érzés, amely egyéni és közösségi (társadalmi) szinten is tapasztalható. ${ }^{129}$ Tapasztalható jelenség, hogy a nemzetközi terrorizmus elterjedésével egyidejűleg, a terrorizmusra adott jogalkotási válaszok tárgyukban és tartalmukban nagy hasonlóságot mutatva jelennek meg, közel azonos időben, más-más államok jogrendszerében. Az erre vonatkozó jogalkotási transzplantáció elméletét Laura K. Donohue amerikai alkotmányjogász dolgozta ki. ${ }^{130}$ A harmadik hipotézis igazolásához - és egyáltalán a kutathatóság feltételeinek megteremtése érdekében - szükséges és a vizsgált jelenségek csoportba rendezéséhez logikai rendező elvként szolgál a félelem koncepciója. A globalizált világban, a 21. század információs társadalmai ${ }^{131}$ elkerülhetetlenül és szükségszerüen reagálnak a világ másik felén zajló eseményekre. A kormányok igyekeznek mindent megtenni a biztonság fizikai garantálásáért, megfelelni a választói akaratnak és persze a vállalt nemzetközi kötelezettségeknek. A terrorveszély vagy legalább annak érzete közvetlenül és a nemzetközi kapcsolatokon keresztül, illetve a választói akarat által közvetetten is meghatározza az állami politikát. Az állami szervezetrendszer mellett a lakosságot is felkészítő intézkedések és programok nemcsak a ténylegesen bekövetkező terrorcselekmény hipotetikus esetére adnak némi támpontot, hanem alkalmasak arra is, hogy a biztonság érzését keltsék a lakosságban. ${ }^{132}$

Az egyéni (egy személyü döntéshozó, a politikus) és a közösségi (politikai) tapasztalás együttes hatására a félelem állami (intézményi) szinten is képes hatás kiváltására. ${ }^{133} \mathrm{~A}$ félelem képes befolyásolni és a jelentősen módosítani azt, hogy a társadalom miként értelmez és értékel egyegy eseményt vagy jelenséget, illetve a politika közvetítésével milyen megoldási javaslatokat

\footnotetext{
129 A kutatás során az egyéni intrapszichés dinamika helyett a társadalmi szinten végbemenő folyamatokra fókuszáltam, a félelemnek tehát a közösségi szinten értelmezhető dimenzióját azonosítom azzal a sajátos közvetítővel, amely közel ugyanazokat a reakciókat eredményezi egy harmadik állam jogi valóságában is. Bővebben a félelemről lásd Kurt A., MoEHLE, Eugene E., LEVITT: The History of the Concepts of Fear and Anxiety. In: Clinical Psychology. Historical and Research Foundations. (editors. C. E., WALKER) Springer, Boston 1991., pp. 159-182.

${ }^{130}$ Laura K., DonOHUE: Transplantation. In: Global Anti-terrorism Law and Policy. 2nd edition. (editors: Victor V., Ramraj, Michael, Hor, Kent, RoACH, George, Williams). Cambridge University Press 2012. (a továbbiakban: DONOHUE), pp. 67-87.

131 PINTÉR Róber (szerk.): Az információs társadalom. Az elmélettöl a politikai gyakorlatig. Gondolat - Új Mandátum, Budapest 2007.

132 Toby, HARRIS: An independent review of London's preparedness to respond to a major terrorist incident. 2016. https://www.london.gov.uk/sites/default/files/londons preparedness to respond to a major terrorist incident - independent review oct 2016.pdf (letöltés dátuma: 2019. 09. 29.)

${ }^{133}$ Andrew TUDOR: A (Macro) Sociology of Fear? In: The Sociological Review 2003/2., pp. 238-256.
} 
részesít előnyben a veszélyhelyzet kezelésére. Marcus a félelemnek közvetlen és közvetett következményeit elemzi és ezzel összefüggésben az alábbi következtetésekre jut. A félelem közvetlen politikai következményei, hogy a növekvő félelem miatt mindent, ami a megszokottól eltérö, félelmetesnek él meg az egyén, egyúttal csökken az agresszív, kockázatviseléssel járó vállalkozások iránti vágya. Vagyis, a félelem által meghatározott pszichés folyamat egyszerre katalizálja magát, elősegítve így az állapot további elmélyülését, mellette pedig semlegesíti az egyik legkézenfekvőbb lehetőséget, amely a folyamattal való szakításhoz vezethetne. Hiszen a kockázatvállalás, a figyelem fókuszának megváltozása, az új kihívások természetes módon zökkenthetik ki az embert a félelem okozta pszichés paralízisből. A félelem közvetett politikai következményei, hogy a sajátos egyéni politikai preferenciák hatásait, illetve a politikai pártok vagy különféle ideológiák hatásait csökkenti az egyénben. ${ }^{134}$ A félelem beszükíti a figyelmet, megbénítja a gondolkodást és nagyon leegyszerüsített, bináris gondolkodáshoz vezethet. Vagyis, a félelem hatására lényegesen könnyebben hagyjuk el korábbi politikai preferenciáinkat, illetve jelentősen módosul a homo politicusban természetesen meglévő kritikai szemlélet.

Különösen akkor érhető tetten és mérhető fel a félelem valódi hatása, amikor azonos kérdésekre szélsőségesen eltérő válaszokat kapunk társadalmi vagy vagyoni szempontból alapvetően homogén csoport részéről. A preferenciák minden esetben politikai következményekkel rendelkeznek és jelentősen befolyásolják a közpolitikák alakulását. A reklámipar mellett a politika az a felület, amely a lehető legegyszerübb és legtömörebb üzenetekkel képes intenzív és primer emberi érzelmek kiváltására. Nem az a cél, hogy egy sikeres választási kampányt követően valamennyi politikai üzenet normatív alakisággal jelenjen meg a jogrendszerben. ${ }^{135}$ Ez lehetetlen vállalkozás volna. Egyrészt, mert nem fogalmazható át minden politikai üzenet a jogalkotás alapvető szabályainak a betartása mellett. Másrészt, ha a politikai üzenet eredeti tömörségében jelenne meg a normák világában, igen nagy eséllyel okozna normakonfliktust.

\footnotetext{
${ }^{134}$ George MARCus: How Fear and Anger Impact Democracy. In: Democracy Papaers Essay 2017. https://items.ssrc.org/democracy-papers/how-fear-and-anger-impact-democracy/ (letöltés dátuma: 2019. 11. 19.) 135 John T. Scholz, Mark Lubell: Adaptive Political Attitudes: Duty, Trust, and Fear as Monitors of Tax Policy. In: American Journal of Political Science 1998/3., pp. 903-920.
} 


\subsection{A félelem hatása a jogalkotásra}

A félelemérzetet vélt vagy valós veszély okozhatja. Hogy melyik, abból a szempontból indifferens, hogy a félelem hatására meghatározott módon cselekszünk, a veszélyérzet miatt átértékeljük az addig határozottan képviselt értékeinket. Azért is mondhatjuk, hogy a veszélyérzet meghatározóbb, mint maga a veszély, mivel kevesen rendelkezünk azonos idejü és adekvát információkkal, de még inkább szakmai ismeretekkel, amelyek segíthetnek minket a veszély valós mértékének felmérésében. A közvetlen fizikai veszély hatására (látvány, testi sérülés, károkozás) testünk automatikus reakciója, hogy megemeli a pulzusszámunkat és testünkben nagy mértékben termelődik az adrenalin. Ezzel felkészülünk a veszélyt szorosan követő fizikai megpróbáltatásokra. A jogrendszer is hasonlóképpen, - kis késéssel - időben és eljárásokban jól elkülöníthető módon reagál a különféle veszélyhelyzetekre. Különleges jogrend bevezetésekor a legfőbb jogalkotó és a legfőbb jogalkalmazó hatalom egy kézben összpontosul, az operativitás megelőzi a jogállami differenciáltság és a fokozatosság elvét. Különleges jogrend bevezetése nélkül is módosul azonban a terrorveszély hatására a rendes jogalkotásra jellemző kifejezetten szegmentált döntéshozatali és jogalkotási eljárás. A szegmentáltság viszont lényegében kizárja, hogy a normatív döntések a veszély valós mértékével szemben, azonos időben, arányosan és végső soron valóban hatékonyan lépjenek fel.

A jogalkotás célja, hogy a jövőre nézve formalizált keretek között, normatív módon leírja, vagyis szabályozza a valóságot. A formalizált keretek elsősorban azt jelentik, hogy a jogalkotásra felhatalmazott szerv, az előírásoknak megfelelően alkotja meg a szabályt és azt ki is hirdeti. ${ }^{136}$ Ugyanakkor azt is jelenti, hogy a jogalkotásra felhatalmazott szerv a szabály megalkotására politikai legitimációval rendelkezik. ${ }^{137}$ A jogszabályok formálisan érvényesek, ha politikailag és jogilag egyaránt megfelelnek ezeknek az elvárásoknak. ${ }^{138} \mathrm{~A}$ megalkotott szabályok szociológiai érvényességét úgy tudjuk meghatározni, ha a társadalom tagjainak normakövetésére alapozva a formálisan érvényes jogszabályok kötelező erejét vizsgáljuk. Ez elméletben a jogszabály szabályozási tárgyától is függhet, azonban a társadalmi elfogadottságot

\footnotetext{
${ }^{136}$ SZILÁGYI Péter: Jogalkotás, törvényhozás, kódex. In: Jogi alaptan (szerk. SzILÁGYI Péter). Osiris, Budapest 2001., pp. 233-264.

137 BIHARI Mihály: Politológia - A politika és a modern állam. Pártok és ideológiák. Nemzedékek Tudása Tankönyvkiadó 2013. (a továbbiakban: BIHARI), pp. 221-237.

${ }^{138}$ SzIGETI Péter, TAKÁCs Péter: A jogállamiság jogelmélete. Második kiadás. Napvilág Kiadó, Budapest 2004. (a továbbiakban: SZIGETI-TAKÁCS), pp. 158-164.
} 
jellemzően nélkülöző jogszabályok - például a közteherviselést szabályozó előírások szociológiai érvényességét a kikényszerítés biztosítja. ${ }^{139}$ Más megközelítésben: ha egy jogszabály a tárgyában közvetetten is csak alig érinti az emberek mindennapjait - például a közigazgatás müködésére vonatkozó belső szabályok -, úgy a szociológiai érvényessége leginkább az érdektelenség, és nem az ellenállás miatt szenvedhet csorbát. Mindez akkor válik igazán érdekessé, ha a jogszabályok szociológiai érvényessége alapvetően a jogszabály elfogadásához kötődő politikai cél legitimációján és így az önkéntes jogkövetésen alapul, miközben a tényleges jogpolitikai cél és az azt közvetítő politikai kommunikáció között eltérés mutatkozik. ${ }^{140}$ Ennek oka egyrészt az lehet, hogy a politikai kommunikáció tömörsége egyszerűen nem teszi lehetővé, hogy a jogpolitikai okok mögött létező jogdogmatika szofisztikáltságát át lehessen adni a laikus tömegeknek. Másrészt a politikai célok és a jogpolitikai célok csak a legritkább esetben fedik le egymást teljes mértékig, többnyire a politikai célokban szintézisre lépő többféle célok egyike csupán a jogpolitika. Ez különösen akkor igaz, ha a jogpolitikai célokat és a politikai célokat nem ugyanazok fogalmazzák meg, amely determinálja a jogpolitika politikához mért viszonylagosságát.

A jogalkotás alapvető jellemzője, hogy (1) tudatosan törekszik normatív szabályok megalkotására, (2) a közigazgatáshoz hasonlóan a jövőre koncentrál, így a jelen szabályozásán keresztül is a jövőt alakítja, (3) a konkretizált, egyedi élethelyzetek helyett általánosan rendelkezik, (4) stabil szabályrendszert alkot, amelyet így (5) egyfajta statikusság is jellemez. ${ }^{141}$ A különleges jogrend bevezetését nem megalapozó vélt vagy valós veszélyek, valamint a különleges jogrend bevezetését megalapozó veszély kialakulásának és kezelésének utólagos értékelése rendszerint egy célzott, retrospektív jogalkotást eredményez, amely érdemi változásokat hozhat a jogrendszerben. A veszélyekkel kapcsolatos jogszabályok felülvizsgálata a jogrendszer várható és tervezett módosítását jelenti, vagyis a veszélyekkel kapcsolatos jogalkotás rendszerint nem tekinthető ad hoc jellegünek. Még abban az esetben is egy folyamatba illeszthető, tehát prognosztizálható - jogalkotási - eseményről beszélhetünk, ha a különleges szabályokat önálló képviselői indítványban terjesztik elő, vagy a szabályozási

\footnotetext{
${ }^{139}$ SZILÁGYI Péter: Jogalkotás, törvényhozás, kódex. In: Jogi alaptan (szerk. SzILÁGYI Péter). Osiris, Budapest 2001., pp. 233-264.

${ }^{140}$ A politikai elem más vonatkozásban viszont éppen a jogrendszer integritását erősítheti. Lásd a politikai kontrollmechanizmusok rendszerét VARGA Zs. András: A közigazgatás jogvédelmi rendszere. In: JAKAB András, FEKETE Balázs (szerk.) IJOTEN (Internetes jogtudományi enciklopédia) (Közigazgatási jog rovat. rovatszerkesztö BALÁzS István) 2017 [57] https://ijoten.hu/uploads/a-kozigazgatas-jogvedelmi-rendszere.pdf (letöltés dátuma: 2019. 09. 29.)

${ }^{141}$ SzABÓ Miklós: A jogforrás. In: SzABÓ Miklós (szerk.): Bevezetés az jog- és államtudományokba. Bíbor Kiadó, Miskolc 2001., pp. 80-84.
} 
(módosítási) igény a települési önkormányzattól érkezik, és nem a kormány részéről merül fel. Valójában az újonnan megalkotott különleges szabály legitimációját sem érinti a jogalkotási eljárást kezdeményező vagy elindító kiléte. Lényeges azonban, hogy az elmúlt veszély és a jogalkotás célja között közvetlen, ok-okozati összefüggés álljon fenn. A veszélyérzet még a tényleges veszély elmúltával is képes befolyásolni a jogalkotásban részt vevő személyek, szervek viselkedését, és így a jogalkotási eljárást magát. Társadalmi-politikai nyomás alatt a jogalkotási eljárásban érintett a számára biztosított határidőt vélhetően nem fogja teljes mértékig kihasználni, az egyeztetésbe bevont véleményalkotók körét azonban a törvényi minimumra szükítik, amely így az eljárásban érintettek számát vertikálisan és horizontálisan is csökkenti. Értelemszerủen így a hiba lehetősége is megnő, a véletlenszerü elírások mellett teret engedve a jogbiztonság szempontjából problémás érdemi (tartalmi, rendszertani stb.) tévedéseknek.

A jogrend jó esetben tükrözi a valóságot, ez elvárás és alapvetés is egyben. ${ }^{142}$ Vagyis, ha a normatív sík és a létező sík - nagyon - eltér egymástól, az előbbi korrekciója szükséges. Mindez fordítva is megtörténhet akkor, ha a létező korrekciójára (befolyásolására) van szükség, és ezt normatív síkon próbálja elérni a jogalkotó. A közjóra - legalábbis abban az értelemben mint a közösség (társadalom) számára hasznos célra - való hivatkozás a kevésbé népszerü jogszabályokat is pozitív színben tünteti fel az elfogadást megelőző társadalmi vitában. ${ }^{143} \mathrm{~A}$ törvények céljához, a közjó lényegéhez tartozik, hogy az emberek közjavára irányul. Vitathatatlan, hogy az emberi lényeg egy része a társadalmi működés egészében nyeri el létezésének teljességét, ezért az ember individuum voltát támadó, őt magát kollektivitásba olvasztó, szolgaságba hajtó rendszer, azaz minden kollektivista totalitárius rendszer filozófiai antropológiailag (is) téves talajon áll. A köz javának tehát egybe kell esnie az egyének javaival, amely megalapozza a lelkiismereti és vallásszabadság, valamint a magán- és családi élet sérthetetlenségét. ${ }^{144}$ Ugyanakkor a létezés, a túlélés alapvető egyéni és közösségi érdeke gyakran összeütközésbe kerül a megkívánt harmóniával, s ezt az egyensúlyt a félelem könnyen billentheti el az ember személyi méltóságába súlyosan és tartósan gázoló rendszerek irányába. A jogalkotó pusztán a köz javára hivatkozva nem képes a jogszabályok természetjogi

\footnotetext{
${ }^{142}$ VARGA Zs. András: A közigazgatás és a közigazgatási jog alkotmányos alapjai. Dialóg Campus, Budapest 2017., pp. 145-147.

${ }^{143}$ Hadley, Arkes: The Axioms of Public Policy. In: David F., ForTE (ed.): Natural Law and Comtemporary Public Policy. Georgetown University Press, Washington DC 1998., pp. 109-134.

${ }^{144}$ FrIVALDSZKY János: A közjó Aquinói Szent Tamásnál és a neotomista természetjogi gondolkodásban. In: Iustum Aequum Salutare 2013/4., pp. 115-139.
} 
érvényességét megteremteni. A nem jogászok számára nem okoz különösebb gondot az igazságtalannak vélt jogszabály be nem tartása, hiszen annak az a természetszerüleg meglévő belső tartalma hiányzik, amely a jogszabályok erkölcsi érvényességét alapozza meg. Egy jogász számára azonban más jelenti a dilemmát, hiszen az a jogszabály, amelyet érvényesen megalkottak (megvitatták és megismerhetővé tették) automatikusan kötelező is lesz, hiszen a jogszabály kötelező erejét érvényességéből nyeri. ${ }^{145}$ Az egyéni felülvizsgálat elvi lehetősége, sőt elismerése, történjen az a jogszabályok kikerülése, kijátszása vagy polgári engedetlenség során, veszélyezteti a jogbiztonságot. Mindez a félelemmel vegyítve - különösen egy valós veszélyhelyzetben - széles skálán eredményezhet súlyos igazságtalanságokat; gondoljunk csak az ilyenkor rendszerint előforduló állampolgári önbíráskodásra vagy a karhatalmi túlkapásokra.

A félelem meghatározását jogilag nehezen tehetjük meg, ám a félelem egyik részelemével, a biztonság hiányával könnyebben célt érhetünk. ${ }^{146}$ A biztonság és a biztonság hiányának meghatározásakor a kettő korrelatív jellegére szoktak hivatkozni, ${ }^{147}$ amely a félelem és a félelem hiánya kapcsán, tehát a biztonságérzet feltárására is alkalmazható. A közbiztonság statisztikailag is kimutatható romlása törvényszerüen magával hozza a büntető jogszabályok szigorodását - gondoljunk csak az ún. három csapás bevezetését megelőző társadalmi vitára -, amely önállóan jelentkező politikai tényezőt kreál. Ez egy természetes folyamat, hiszen a közösségi létben, a társadalmi együttélésre vonatkozó döntések és az ezt megelőző társadalmi vita (együtt gondolkodás) mindig politikai síkon zajlik. ${ }^{148}$ Ezért alapvetően azok a politikai kezdeményezések kapnak erősebb társadalmi legitimációt, amelyek egy-egy üzenet vagy program mögé a legszélesebb társadalmi szükségletet (igényt) képesek felsorakoztatni, illetve hitelesen képviselni. A jogalkotás, ahogyan Karl Renner megfogalmazta, a szociális problémák és feladatok, vagyis a társadalomirányítás legfőbb és legalkalmasabb eszköze.

A jogalkotás célja, hogy az állami, társadalmi és gazdasági rendet normatív, vagyis elöíró szabályozással biztosítsa és fenntartsa. Egy új jogszabály mindig változtat a jogrendszeren, teljesen mindegy, hogy kódex jelleggel magában foglalja-e a jogterület jellegzetességeit, vagy csupán jogtechnikai finomhangolás céljából alkották meg. A normatív módon elöírt magatartás a kikényszerítés által - előbb-utóbb - valósággá válik. Így a normatív cél mellett más

\footnotetext{
${ }^{145}$ SZIGETI-TAKÁCS, pp. 324-328.

${ }^{146}$ Vö. Vajnai v. Hungary EJEB 2008.

147 ÁDÁM Antal: A biztonság az értékek között. In: Jura 2005/1., pp. 33-41.

${ }^{148}$ PоKOL Béla: Politikaelmélet - Társadalomtudományi trilógia III. Századvég, Budapest, 2006. (a továbbiakban: POKOL), pp. 33-37.
} 
szempontokat is szem előtt tartó jogszabályok - gondoljunk csak a különleges jogrendben vagy bármely erős társadalmi nyomás alatt született jogszabályokra - jogrendszerre gyakorolt hatása is árnyaltabb lesz. Sokszor észrevétlenül, de a rejtve maradt járulékos szempontok is ugyanúgy a jogrendszer részévé válnak, még ha nem is oly’ egyértelműen és a jogalkalmazás során közvetlenül, mint maga az írott jog, de szellemiségük a továbbiakban meghatározza a jogértelmezést.

A félelem egyénileg és közösségben való megélése nagy mértékben kihat az állami élet minden dimenziójára, így a jogalkotási folyamatokra és a kormányzásra egyaránt. A jogalkotást akkor érinti a félelem közvetlenül, ha pusztán kormányzati (adminisztratív) eszközökkel a félelem negatív hatásai nem kezelhetők. A jogpolitika ilyenkor három viszonylag gyors hatást céloz meg: (1) több jogi eszközt a hatóságok számára, és (2) a közigazgatási szervezetrendszer átalakítását, amelyekkel összességében a hatékonyság növelhető, valamint (3), új büncselekményi tényállások létrehozatala vagy a meglévők büntetési tételének növelése, ${ }^{149}$ amely elégséges visszatartó erővel bír majd a rend további fenntartásához. Vagyis új jogszabályok megalkotásával vagy a meglévő hatályos normák módosításával éri el a jogalkotó azokat a célokat, amelyek a félelem kezeléséhez szükségesek. Azokat a jogalkotási folyamatokat, amelyeket alapvetően ezek a célok határoznak meg politikai vagy jogi szükségszerüség is jellemez egyúttal. A félelemhez kapcsolódó jogalkotás - tehát új normák megalkotása vagy a meglévő hatályos joganyag megfelelő módosítása - közvetlenül hatnak a jogrendszerre. Jellemző, hogy ezeket a szabályokat rövid határidővel, gyorsított eljárásban és gyors hatályba lépéssel alkotják meg. ${ }^{150}$ A gyors hatályba lépés általában két dolgot jelent: egyrészt a jogalkalmazók már felkészültek - intézményi és eszközök tekintetében - az új szabályok alkalmazására, tehát a hatályba lépésig a rövid felkészülési idő mindenképpen elégséges, másrészt nagy eséllyel már eleve a módosított szabályok szerint jártak volna el, ha azt nem tiltotta volna korábban hatályos jogszabály. A félelem politikai vetülete a (veszély)helyzet valóságos megoldását érintő eredményesség mellett normatív

\footnotetext{
${ }^{149}$ Az egyes törvényeknek a tömeges bevándorlás kezelésével összefüggő módosításáról szóló 2015. évi CXL. törvény (a továbbiakban: migrációs salátatörvény) § 26-32. §-ai, amelyek a Btk.-t módosították és létrehozták az alábbi tényállásokat: a határzár tiltott átlépése, a határzár megrongálása és a határzár építésének megakadályozása. A válság okairól bővebben lásd SzUHAI Ilona, TÁlAs Péter: A 2015-ös migrációs és menekültválság okairól és hátteréröl. In: TÁLAS Péter (szerk.): Magyarország és a 2015-ös európai migrációs válság. Dialóg Campus, Budapest 2017., pp. 9-34.

${ }^{150}$ Az európai migrációs válság 2015 augusztusában tetőzött Magyarországon, amely ahhoz vezetett, hogy az Országgyülés 2015. szeptember 4-én elfogadta a migrációs salátatörvényt, amelyet szeptember 9-én aláírt az államfö és szeptember 16-án már hatályba is lépett. Vagyis a törvény elfogadása és a hatályba lépése között kevesebb, mint 2 hét telt el.
} 
eredményességet is feltételez. Ez azt jelenti, hogy a jogalkotási eljárásban a legalitáshoz szükséges minimumra csökkennek a belső határidők, illetve a jogalkotó hatékonysági okokból egy jogalkotási aktussal fogja több helyen módosítani a jogrendszert, vagyis az ún. salátatörvényeket fogja előnyben részesíteni. ${ }^{151}$

A félelem által befolyásolt jogalkotás ugyanakkor nem csupán közvetlenül hat ki a jogrendszerre, hanem közvetett módon és hosszútávon is kifejti hatását, amelyek sokszor nem olyan egyértelmủek, sőt, látens módon érvényesülnek. A közvetett hatásokat három kategóriába sorolhatjuk: (1) zsinórmérték, (2) a tóba dobott kő, és (3) porszívóhatás. ${ }^{152}$

A rendkívüli eseményre tekintettel megalkotott jogszabályok mindenképpen biztonsági tárgyú jogszabályok lesznek, függetlenül attól, hogy milyen jogágban vagy jogterületen hoznak változást. Még akkor is meghatározó lesz a biztonsági tényező, ha az a tervezett normaszövegből nem tünik ki, hiszen legalább az előterjesztés indokolásában hivatkoznak erre. Nem feltétlenül segíti elő az egységes jogértelmezési gyakorlat kialakulását és így a jogbiztonságot, ha egyes jogszabályok esetében egyedül az autentikus értelmezés ad valódi magyarázatot a jogszabály értelmezéséhez. ${ }^{153} \mathrm{Az}$ ilyen indíttatású szabályozási kezdeményezések mögött minden esetben erős társadalmi legitimáció húzódik meg. Ennek magyarázata, hogy a (létező) veszélyre is tekintettel lévő szabályt mindig könnyebb elfogadtatni, mint esetleg a veszélyt (tudatosan) figyelmen kívül hagyó szabályt. Ez különösen igaz akkor, ha - újabb - jogkorlátozást vezet be a jogszabály. Érthető, hogy veszély(érzet) nélkül az emberek nehezebben nyelik le a jogkorlátozás keserü piruláját, míg a veszély-retorika úgy hat ilyen esetekben, mint az édesítőszer.

A biztonsági tárgyú jogszabályok további legitimációs és rendszertani jellegzetessége, hogy hatályba lépésükkel, vagyis ahogyan a jogrendszer részévé válnak, egyúttal a biztonság jogrendszeri alapvonalát is újra kijelölik. Mivel nem különleges jogrendi szabályokról beszélünk, így a rendkívüli eseményre való hivatkozás valójában csak a jogszabály megalkotásakor lesz mérvadó, a jogalkalmazáshoz nem tesz hozzá, a jogértelmezésre -

\footnotetext{
${ }^{151}$ Ahogy ez a migrációs salátatörvény esetében is látható.

152 Vö. Donohue a jogi transzplantáció körében megállapítja, hogy a transzplantáció megvalósulhat (1) kulturálisan, jogilag, vagy nyelvileg kapcsolatban lévő államok, (2) fejlett és fejlődő országok között, (3) egyes regionális folyamatokra való reflexióval, vagy rácsatlakozással, (4) nemzetközi szervezeteknek a standardizálásra (másként: valamilyen nemzetközi szabályozás megalkotására) tett koncentrált lépései következményeként. Lásd DONOHUE, p. 69.

153 TAMÁS András: Legistica. A jogalkotástan vázlata. Szent István Társulat, Budapest 2005.
} 
érdemben - nem hat ki. A későbbiekben a rendkívüli eseményre tekintettel megalkotott jogszabály már csupán egy lesz a jogrendszer számos hatályban lévő jogszabályai közül és a megalkotásakor biztonsági-megfontolásból keletkezett kárászéletü legitimáció már akár feledésbe is merülhet. A jogszabály hatályosságán ez mit sem változtat. Viszont a biztonsági tárgyú szabályalkotásra (is) jellemző az a hétköznapi laikus megfontolás, miszerint a biztonságból sosem elég. Így valójában a jogalkotó valamennyi későbbi jogszabály vonatkozásában egyfajta zsinórmértékként jelöli ki a maga számára a megalkotott normát. ${ }^{154}$

Ezt jól személtető példa az Egyesült Államokban 2002 januárjában elindított MATRIX pilot kutatás, ${ }^{155}$ amely müködési ideje alatt jelentős mértékü anyagi támogatásban részesült a szövetségi kormányzattól és felületesen a jogszabályi hátterének rendezésére is tettek lépéseket. ${ }^{156}$ Hozzátartozik az igazsághoz, hogy a kutatás alapját képező adatfúziós elemző eljárás a 9/11-es terrortámadást követően néhány hét alatt eredményesen felderítette a hatóságok számára az elkövetőket segítő, szökésben lévő személyeket. Mindazonáltal a Department of Homeland Security engedve az egyre gyakoribb alkotmányos aggályoknak 2005. december 31-ével felmondta az Egyesült Államok Kormánya és a programot müködtető LexisNexis informatikai szolgáltató között fennálló szerződést. ${ }^{157}$ Maga az adatfúziós elemző eljárás ugyanakkor nem szűnt meg, sőt az elmúlt másfél évtizedben többször telepítették új szervezethez, illetve nevezték át, minden esetben a biztonsági kihívásokra tekintettel. ${ }^{158}$

A 2001-et követő politikai és társadalmi változások nagy mértékben befolyásolták az Egyesült Államok jogrendjét. A változások zászlóshajójának lehet tekinteni a Patriot Act $^{159}$ névvel hazafias köntösbe bújtatott törvényt. A normaszöveg hatályban tartásáról elöször 2006-ban, majd 2011-ben is döntést hozott a Kongresszus. A normaszöveg nagy része hatályát vesztette 2015. június 1-jén, amikor lejárt a határidő az újabb meghosszabbításra. Ugyanakkor közel

\footnotetext{
${ }^{154}$ Lásd bővebben SABJANICS István: A félelem mint jogi következményekkel járó veszélyforrás. In: FinSZTER G., SABJANICS I. (szerk.) Biztonsági kihívások a 21. században. Dialóg Campus, Budapest 2017., p. 752.

${ }^{155}$ Multistate Anti-Terrorism Information Exchange Pilot Project (2002-2004)

${ }^{156}$ Bővebben kifejtve ld. SABJANICS István: Adatvédelem és terrorellenes intézkedések az Egyesült Államokban. A MATRIX modellkisérlet története és visszhangjai. In: Modellkísérletek a közigazgatás fejlesztésében. Az ún. „pilot projektek” határai elméletben és gyakorlatban. (Szerk.: Gerencsér Balázs Szabolcs). Pázmány Press, Budapest 2013., pp. 79-88.

157 MATRIX Report - DHS Privacy Office Report to the Public Concerning the Multistate Anti-Terrorism Information Exchange (MATRIX) Pilot Project, December 2006, Homeland Security https://www.dhs.gov/sites/default/files/publications/privacy-matrix-122006.pdf (letöltés dátuma: 2019. 09. 29.)

${ }_{158}$ Total Information Awarness, Terrorism Information Awarness, Basketball

159 Teljes nevén U.S.A.P.A.T.R.I.O.T.A.C.T., amely kibontva a következö: Uniting and Strenghtening America by Providing Appropriate Tools Required to Intercept and Obstruct Terrorism Act of 2001 Public Law 107-56 2001 10. 26. https://www.sec.gov/about/offices/ocie/aml/patriotact2001.pdf (letöltés dátuma: 2019. 09. 29.)
} 
azonos normatartalommal a Kongresszus 2015. június 2-án elfogadta a Freedom Act $^{160}$ nevü törvényt, amely gyakorlatilag azonos tartalmú rendelkezéseket tartalmazott. A normát többen bírálták, de legalább annyian támogatják is. ${ }^{161}$ A Patriot Act módosította az ún. domestic terrorism $^{162}$ (hazai terrorizmus) egyébként is igen laza meghatározását, amely miatt további jogszabályoknak a fogalomra épített szankcióit szinte diszkrecionális jogkörben alkalmazhatta a hatóság. ${ }^{163}$ Gyakorlatilag egy-egy politikai tüntetés résztvevőivel szemben is általánosan alkalmazhatóvá vált az a jogalkalmazói mérlegelés, hogy a kormányzat (döntése) ellen tüntető állampolgárok a hazai társadalmi-politikai viszonyok között legalább olyan destruktív elemek, föleg a kisebb közösségek szemében, hogy hasonló megítélés alá esnek, mint a nemzetközi terrorizmust elkövetők. ${ }^{164}$ Az adózók nyilvántartásával kapcsolatosan a jogszabály megteremti annak a lehetőségét, hogy a hatóság akár a környezetszennyezés ellen tüntetők adózási adataihoz is hozzáférjen. ${ }^{165}$ A biológiai hatóanyagokról és méreganyagokról szóló szabályozás lehetővé teszi, hogy megtagadják a hozzáférést a szabályozással érintett összetevőkhöz olyan személyek esetében, akiket a terrorizmussal hoz összefüggésbe a hatóság. ${ }^{166}$ Az előző példát továbbgondolva, egy környezetszennyezés ellen tüntető vegyész vagy biológus kutató munkáját lehetetlenítené el, ha a hazai terrorizmus fogalmának tág értelmezése miatt a hatóság megtagadná a továbbiakban az alapanyagokkal és komponensekkel való ellátását.

A megalkotott jogszabály minden esetben változást hoz a jogrendszerben: hozzátesz, átalakítja vagy elvesz belőle. Azonban a jogszabály előbbi közvetlen hatásain túl, olyan változásokat is

\footnotetext{
${ }^{160}$ Uniting and Strenghtening America by Fullfilling Rights and Ensuring Effective Disciple Over Monitoring Act of 2005 Public Law 114-23 2015. 06. 02.

${ }^{161}$ John, PoDESTA: USA Patriot Act: The Good, The Bad, and the Sunset. In: American Bar Association 2002/1., pp. 3-4, 7.

${ }^{162}$ US Code Title 18. Code $\$ 2331$ (5) alapján a hazai terrorizmus (domestic terrorism) megvalósítható olyan cselekményekkel, amelyek:

(A) az emberi életre veszélyesek és önmagukban szövetségi vagy állami büncselekményi tényállást valósítanak meg;

(B) láthatóan arra irányulnak, hogy:

(i) a lakosságot megfélemlítse vagy kényszerítse;

(ii) a kormányzati politikát befolyásolják megfélemlítéssel és kényszerítéssel; vagy

(iii) valamilyen módon befolyásolják a kormányzati tevékenységet tömegpusztítással, merénylettel vagy emberrablással; és

(C) elsődlegesen az Egyesült Államok területén valósulnak meg;

${ }^{163} \mathrm{Az}$ American Civil Liberties Union sem bírálja a jogsértő cselekményért kiszabott arányos és indokolt büntetést, azonban az arányosság követelménye nem áll fenn olyan személyek és csoportok vonatkozásában, akik és amelyek akár bele is eshetnek a domestic terrorism kategóriájába, holott tevékenységük se nem eröszakos, se nem esik bele a terrorizmus klasszikus elkövetési magatartási körébe. ld. bővebben: https://www.aclu.org/other/how-usa-patriotact-redefines-domestic-terrorism (letöltés dátuma)

${ }^{164}$ Érdekes gondolatkísérlet lenne az amerikai ún. domestic terrorism fogalmi fejlődését összevetni, a spanyol jog ETA-hoz, vagy az angol jog IRA-hoz való viszonyulásával.

${ }^{165}$ US Code Title 26 Section 6103 (i) (3) (C).

${ }^{166}$ US Code Title 42 Section 262a és US Code Title 7 Section 8401.
} 
előidézhet - különösen igaz ez a biztonsági tárgyú jogszabályokra -, amelyek elöre ki nem számítható hatásokat váltanak ki, hasonlóan a tóba dobott kő által vert hullámokhoz. Hiába az eredeti jogalkotói szándék, vagy a szükséges hatásvizsgálatok, ha a jogszabály megalkotásakor megjelölt célok előre nem látható, de szükségszerü további jogrendszeri változásokkal érhetők csak el. Vagyis, a jogszabály teljes körü alkalmazásához nem elegendők a jogszabály hatálybalépésével egyidejüleg bekövetkező jogrendszeri változások, hanem a jogrendszer további finomhangolására van szükség. Különösen igaz ez akkor, ha jogági áttétekről beszélünk, vagyis például a dominánsan büntetőjogi vagy hatósági jogi megoldások mellé magánjogi elemekkel kevert biztonsági-tárgyú jogszabályokat alkotnak meg. Az Európai Unió valamennyi tagállama közremüködik az Europol terrorellenes tevékenységének támogatásában, illetve a European Counter Terrorism Centre mellett a tagállami hatóságok is figyelemmel kísérik az online radikalizációs folyamatokat és a toborzást. Ugyanakkor, az elmúlt évek gyakorlata azt mutatta, hogy minden intézkedés hiábavaló a közösségi média szolgáltatók hathatós közremüködése nélkül. Így, ma a radikális tartalmak elérhetetlenné tételének sikere, ha nem is kizárólagosan, de igen nagy mértékben függ a szolgáltatók és a felhasználók közötti jogviszony tartalmától. A radikális tartalmak jelentős részét a szolgálatók által meghatározott Általános Szerződési Feltételek ${ }^{167}$ alapján távolítják el az Internetről és így a magánjogi megfontolások mellett árnyaltabbá válik a korábban domináns közjogi és főként büntetőjogi jelleg.

Az egyes politikai témakörök társadalmi elfogadottsága koronként és államonként változó, ugyanakkor az állam belpolitikai stabilitásához hozzátartozik, hogy rendkívüli esemény híján az eredménnyel tárgyalható politikai témakörök tárgya és száma kiszámítható. A rendkívüli eseményre való tekintettel azonban olyan legitimációs turbulencia alakulhat ki, amely a porszivóhoz hasonlóan, korábban nagy valószínüséggel eleve kudarcra ítélt témakörökben is hozhat a jogszabálytervezetnek nem várt népszerüséget. Általánosan nehéz volna ezt a jelenséget elismeréssel vagy bírálattal illetni, hiszen java részt azon múlik az így elfogadott jogszabály objektív megítélése, hogy mennyiben szolgálja a közjót. Ezt pedig egyedileg lehet csak megítélni. Az állam és az egyház szétválasztása régóta jelen van az európai demokráciákban, bár ennek tényleges tartalma országonként eltérhet. ${ }^{168}$ A nyugat-európai

\footnotetext{
${ }^{167}$ Lásd a kérdés vonatkozásában egyebek mellett a Facebook, a Twitter és a Snapchat felhasználására irányadó szabályokat.

168 Erről bővebben lásd SchAnda Balázs: Magyar állami egyházjog. Szent István Társulat, Budapest 2003.; továbbá SzATHMÁRY Béla: Az állam és az egyházak elválasztott müködése a gyakorlatban Magyarországon. (Habilitációs eljárás tézisei) Debreceni Egyetem Állam- és Jogtudományi Doktori Iskola, Debrecen 2010.
} 
társadalmak jellemzően heterogénebbek, mint a kelet-közép európai országok, amelyek társadalma továbbra is nagyrészt a történelmileg kialakult struktúrában létezik. Svájcban civil kezdeményezés alapján 2009-ben népszavazást tartottak a minaretek építésének korlátozásáról, amelyet sem nemzeti fórum előtt, ${ }^{169}$ sem az Emberi Jogok Európai Bírósága előtt nem sikerült ${ }^{170}$ eredményesen megtámadni. A népszavazás eredményeképpen a svájci alkotmány Egyházról és államról szóló 72. cikke kiegészült egy 3. bekezdéssel, amely kimondja: Svájcban minaret építése tilos. ${ }^{171}$ Svájcban nem történt az elmúlt évtizedekben iszlámista terrorcselekmény, ${ }^{172}$ ugyanakkor a terrorizmus hatására Európában kialakult általános iszlámellenesség begyürüzött a svájci társadalomba is. A döntés egyértelmü célja a svájci (keresztény) identitás megőrzése, vagyis az alkotmánymódosítást egy olyan vélt veszélytől való félelem alapozta meg, amely Svájcban messze nem érvényesül olyan mértékben, mint Nyugat-Európa egyes társadalmaiban.

A rendkívüli eseményre eltérő választ adhat a jogalkotó és a jogalkalmazó. A jogalkotás feltétlenül hosszútávon érvényesül, kihat a jogrendszer egészére, míg a jogalkalmazás alapvetően rövid távon tervez. Jogalkalmazás alatt a kérdéses esemény méretétől függően beszélhetünk a kormányzati intézkedésekről, területi igazgatási vagy települési önkormányzati döntéshozatalról. Egy relatíve gyorsan meghozott közigazgatási döntés, eseti meghatározottsága miatt alkalmasabb arra, hogy a rendkívüli eseményre közvetlenül és késlekedés nélkül adjon választ. A jogalkotás vontatottabbnak tünik a jogalkalmazáshoz képest, hiszen a jogalkotási eszközök eleve közép- vagy hosszútávon és föként általánosan érvényesülnek. Ezért a rendkívüli eseményre született jogalkotói és jogalkalmazói válaszok között jelentős eltérés áll fenn. Az intézkedések könnyebben idomulnak a valóságban bekövetkező változásokhoz. Így az esemény ideje alatt, valamint ahhoz időben szorosan közel lehetnek határozottabbak, vagyis az ingához hasonlóan kilenghetnek. Az eseménytől távolodva vagy a rendkívüli esemény káros hatásainak csökkenését követően enyhülhetnek, vagyis az inga nyugvópontra térhet. Ezzel szemben a jogszabályok nem önmagukban, hanem a jogrendszer részeként egymás mellett, egymásra hatással és egymásra tekintettel léteznek. Ezért

\footnotetext{
${ }^{169}$ Bővebben kifejtve lásd SABJANICS István: Összehasonlitó elemzés a vallásszabályozás kérdéskörében európai kitekintéssel, különös tekintettel a vallásgyakorlás színhelyére vonatkozó kötelezö állami elöirásokra. In: Religio et constitutio. (Szerk.: KovÁcs Péter) Pázmány Press, Budapest 2014., pp. 102-103.

${ }^{170}$ Quardiri v. Svájc (65840/09), Ligue des Musulmans de Suisse és Mások v. Svájc (66274/09)

171 A népszavazás napjától, vagyis 2009. november 29-től hatályos az alkotmány kiegészítéssel módosított szövege.

${ }^{172}$ A terrorizmus ugyanakkor a svájci társadalmat sem kerülte el: az ún. luxori mészárlásban 36 svájci állampolgárt gyilkoltak meg iszlámisták Egyiptomban.
} 
a biztonsági tárgyú jogszabályokra nem az inga-hatás lesz a meghatározó, hanem a spirál-hatás. A spirál-hatás lehet negatív vagy pozitív, annak megfelelően, hogy a biztonsági tárgyú jogalkotás indokolt szigorítást vagy a veszély csökkenésére tekintettel enyhülést hozhat. Azonban jellemző, hogy a negatív spirál mindig gyorsabb jogalkotást eredményez és könnyebb rá átváltani, mint a pozitívra, továbbá a jogalkotás csak nehézségek árán képes a spirált elhagyni.

A biztonsági tárgyú jogszabályok megalkotására ritkán kerül sor nyugodt politikai körülmények között. Így a jogszabály részletes, akár társadalmi vitával egybe kötött, érdemi megtárgyalására nem minden esetben van lehetőség. Különösen igaz ez akkor, ha a jogszabályt a megalkotását megalapozó rendkívüli esemény fennállása alatt, vagy ehhez időben szorosan közel alkotják meg. A rendkívüli esemény miatt kialakuló társadalmi elvárások egyszerre terhelik az állami vezetőket és a közigazgatást. Ennek hatására a kodifikációs munkát végzőkre különösen nagy nyomás nehezedik a jogszabály-tervezet előkészítő munkája során. Szoros határidőkkel dolgoznak, illetve a közigazgatási egyeztetésbe bevont szervezeteknek szinte jelképes időt szánnak a jogszabály-tervezetek véleményezésére. Ez nagy eséllyel imperfekt normák megjelenéséhez fog vezetni a jogrendszerben, amely a jogszabályok egymásra utaltsága miatt elöre nem látható következményeket is vonhat maga után. Végső soron ez a jogalkotót - minden előzetes szándéka ellenére - egyfajta korrekciós kényszerpályára helyezi. A terrorcselekmények elkövetésének magas valószínüsége komoly nyomást helyez a jogalkalmazókra és a jogalkotóra, amely adott esetben futószalagon gyártott jogszabályalkotást is eredményezhet. Erre szemléltető példa az Egyesült Királyság, ahol 2001. szeptember 11. óta összesen közel 20 db - időnként egymást váltó és egyre szigorodó - biztonsági tárgyú jogszabályt fogadtak el. Ebbe a sorba tartozó egyik eklatáns példa a 2016-os Investigatory Powers Act, amely legitimálta az Egyesült Királyság globális megfigyelési kapacitását megteremtő programokat. ${ }^{173}$ A programokat és a müködtetésük keretét adó normatív hátteret az Emberi Jogok Európai Bírósága 2018 szeptemberében jogellenesnek nyilvánította és ezzel újra elindította a Westminster biztonsági tárgyú jogalkotásának szűnni nem akaró és közel két évtizedes motorját

\footnotetext{
${ }^{173}$ Ezek sorban a 1) Tempora az Európa és Észak-Amerika között zajló kommunikáció szinte egészét lefedő program az Atlanti óceán fenekén futó üvegszálas optikai kábelre csatlakozik rá fizikailag; a 2) Karma Police az internet felhasználók online aktivitását tárolja és elemzi, amely alapján hosszútávú következtetéseket von le a jövőbeni, még meg nem valósult online tevékenységre; és végül a 3) Black Hole közel 3 ezer milliárd internetes adatot tárol.
} 
Egy másik szemléltető példa a francia parlament többszöri próbálkozása egyes internetes tartalmak kriminalizálására. Először 2016. május 19-én fogadták el azt a salátatörvényt, ${ }^{174}$ amely egyebek mellett büntetőjogi szankciókkal sújtotta azt, ha valaki terrorizmussal kapcsolatos online tartalmakat nézett meg (vagyis letöltött), sokszorosított (vagyis megosztott), illetve véleménnyel látott el (vagyis kommentált). Az csupán minősítő körülmény, ha ezzel a cselekményével a terrorizmust igazolja, vagy terrorizmus elkövetésére felhív az elkövető. Kivételként három kategóriát említ a jogszabály: 1.) a hivatásszerü tömegtájékoztatást; 2.) a tudományos kutatást; valamint 3.) a büntetőeljárásban bizonyítékként felhasználható adattartalmat. Alapesetben 2 évig terjedő szabadságvesztés büntetése és $30000 €$ pénzbüntetés szabható ki, míg minősített esetben 5 évig terjedő szabadságvesztést és $75000 €$ pénzbüntetést határoz meg a törvény. A büntetési tételek súlya is arról tanúskodik, hogy a jogalkotónak nagyon komoly szándékában állt a lakosság - tipikusan a közösségi médiában előforduló - a terrorcselekményekröl, illetve az elkövetőkről vagy az áldozatokról szóló véleményének és az adatoknak a visszaszorítása. Ez természetesen magyarázható az életben maradt áldozatok személyes adatainak és az elhunyt személyek kegyeleti jogának a védelmével, továbbá a radikalizáció további terjedésének a megakadályozásával. Ugyanakkor a normaszöveg beemeli az elkövetési magatartások körébe a jószándékú, együtt érző, esetleg felháborodott véleménykifejezést is, ez pedig már átlép egy határt. Ezzel ugyanis általános cenzúrát vezet be az állam, amely messzemenőkig sérti a véleménynyilvánítás szabadságát. Még abban az esetben sem fogadható el a jogalkotói magyarázat, ha ezzel a szünni nem akaró terrorizmus terhe alatt lévő francia társadalomban kívánja visszaszorítani az általános pánik tovább terjedését és a helyzet eszkalálódását. Erre a megállapításra jutott az Alkotmánytanács (Conseil constitutionnel) is és 2017. február 10-én hatályon kívül helyezte a módosított rendelkezéseket. ${ }^{175}$ A jogalkotó nem adta fel, hiszen egy héten belül, 2017. február 15-én már el is fogadott egy új törvényt, ${ }^{176}$ amely kissé cizellálja a korábbi módosítást, illetve némileg teret enged a vádhatóság mérlegelésének, s ezzel árnyalja a tényállást megvalósító magatartási formákat. Az Alkotmánytanács álláspontja szerint az így módosított jogszabályi rendelkezések sem feleltek meg az alkotmányos követelményeknek és azokat 2017. december 15-ével

\footnotetext{
174 PROJET DE LOI renforçant la lutte contre le crime organisé, le terrorisme et leur financement, et améliorant l'efficacité et les garanties de la procédure pénale http://www.assemblee-nationale.fr/14/pdf/ta/ta0735.pdf (letöltés dátuma: 2019.09.29.)

${ }^{175}$ Décision n 2016-611 QPC du 10 février 2017 https://www.conseil-constitutionnel.fr/decision/2017/2016611QPC.htm (letöltés dátuma: 2019. 09. 29.)

176 PROJET DE LOI relatif à la sécurité publique http://www.assemblee-nationale.fr/14/pdf/ta/ta0915.pdf (letöltés dátuma: 2019. 09. 29.)
} 
hatályon kívül helyezte. ${ }^{177} \mathrm{~A}$ kérdés további tisztázása részben okafogyottá vált, ${ }^{178}$ mivel a 2017-es választásokat követően az új kormány választási ígérete és határozott szándéka volt, hogy a közel két éve tartó különleges jogrendet megszünteti és a rendes jogrend keretei között fogják kialakítani a biztonság garantálásához elengedhetetlen normatív feltételeket.

A rendkívüli esemény politikai interpretációja nagyban függ attól, hogy az esemény időben mennyire áll távol a politikai értékeléstől, káros hatásai mennyire érzékelhetők. A retrospektív nézőpont alapvetően nagyobb szabadságot biztosít az objektivitásra, de a felületes értékelésre is. A válságkezelést övező apró részletek önmagukban vizsgálva jelentéktelen és talán véletlenszerü párhuzamosságnak tünhetnek, azonban összefüggéseikben vizsgálva őket, lehet, hogy nagyobb jelentőséggel bírnak a rendkívüli esemény hatásainak intenzitását vagy elhúzódását illetően. Jellemző, hogy a rendkívüli események idején a kormány kivételesen magas legitimáció mellett végezheti a válságkezelést, azonban a hirtelen jött társadalmipolitikai egység könnyen tova szállhat a válság lecsengését követően, ${ }^{179}$ és ez nagy mértékben kihat az állam politikai kultúrájára. Jól példázza mindezt a 2005-ös franciaországi lázadások hatósági kezelése és azok utólagos értékelése. Néhány fiatal véletlenszerü halála és mások örizetbe vétele ahhoz vezetett, hogy becslések szerint a zavargásokban közel 25 ezer személy vett részt, akik közül több 2800 gyanúsítottat vettek örizetbe. Az események folyamatos eszkalálódása és a helyzet súlyosbodása ahhoz vezetett, hogy három hétig tartó különleges jogrendet vezettek be Franciaországban. Mikor az erőszakhullámot végül sikerült megfékezni, a hatóságokat kezdték hibáztatni azért, hogy a helyzet egyáltalán kialakult. A probléma értékelése akkor lépett magasabb politikai szintre, amikor a zavargások idején belügyminiszteri posztot betöltő Nicolas Sarkozy és az ellenzéki elnökjelölt Ségolène Royal közötti vitákban kiemelt helyen szerepelt a hatóságok kapcsolata a bevándorlókkal, valamint a francia politika asszimilációs törekvései.

\footnotetext{
177 Décision n 2017-682 QPC du 15 décembre 2017 https://www.conseil-constitutionnel.fr/decision/2017/2017682QPC.htm (letöltés dátuma: 2019. 09. 29.)

${ }^{178}$ Deklaráltan gondolatkísérletnek szánt írás a kérdésröl lásd Bérénice BouTıN: Excesses of Counter-Terrorism and Constitutional Review in France: The Example of the Criminalisation of the Consultation of Websites. 2018. május 10. https://verfassungsblog.de/where-visiting-a-website-is-now-a-crime-excesses-of-counter-terrorismand-constitutional-review-in-france/ (letöltés dátuma: 2019. 09. 29.)

${ }^{179}$ A válság ideje alatt érvényesül az erősebbhez való húzás elve, amely időnként nem fokozatosan csökken, hanem gyors politikai visszarendeződéssel jár együtt.
} 


\subsection{A félelem hatása a jogértelmezésre}

A 2016. július 14-én este, Franciaország legnagyobb nemzeti ünnepét (le jour de la Bastille) záró grandiózus tüzijátékot követően végrehajtott nizzai gázolásos terrortámadásnak 86 halálos áldozata volt. A terrortámadást követően a közhangulatra és a közbiztonság fenntartására hivatkozva a tengerparti helyhatóságok betiltották a kijelölt fürdőhelyeken az ún. burkini ${ }^{180}$ használatát, amely erősen megosztotta a francia társadalmat. A franciaországi székhelyü Emberi Jogi Liga keresetet nyújtott be a közigazgatási bíróságra abból a célból, hogy a burkini használatát tiltó 2016. augusztus 5-én kiadott Villeneuve-Loubet helyi önkormányzati rendelet végrehajtását azonnali hatállyal függessze fel és a jogszabályt semmisítse meg. A kereset különösen a rendelet 4. cikkének 3. pontját, amely megtiltotta a nem megfelelő ruházatot viselöknek, hogy június 15 . és szeptember 15. között az önkormányzat területén fekvő tengerparti kijelölt fürdőhelyeken fürödjenek. A jogkorlátozás indokolásaként a megfelelő ruházatot úgy határozták meg, mint amely nem ütközik a jó erkölcsbe és a szekularizmus alapelvébe, továbbá megfelel a fürdőzésre vonatkozó higiéniai és biztonsági előírásoknak. Keresetükben arra hivatkoztak a civil szervezet képviselöi, hogy a megtámadott jogszabály nem egyértelmü és sérti az emberek gondolat- és vallásszabadságát.

A nizzai közigazgatási fellebbviteli bíróság 2016. augusztus 22-én elutasította a keresetet. ${ }^{181}$ Indokolásukban arra hivatkoztak, hogy az állam alkotmányban kimondott és mindenkitől megkövetelt szekularizmusa az egyén vonatkozásában azt jelenti, hogy az egyének által gyakorolt vallási meggyőződések békés egymásmellettiségben kell, hogy létezzenek és nyilvánuljanak meg. Néhány nappal a helyi önkormányzati rendelet kiadását megelőzően, 2016. július 26-án iszlámista radikálisok túszul ejtettek 5 személyt és kegyetlenül meggyilkoltak egy idős katolikus papot a templomában Saint-Étienne-du-Rouvray településen. A nizzai gázolásos merénylet pedig mindössze 12 nappal korábban történt. A két cselekmény között a bíróság értelmezésében az volt a különbség, hogy míg a nizzai merénylet - a korábban elkövetett párizsi merényletekkel egyetemben - általánosan a francia társadalmat célozta, addig a kis településen elkövetett emberölés kifejezetten a kereszténységet célozta. A terrorizmus

\footnotetext{
${ }^{180}$ A burkini, amely elnevezés a burka és a bikini keresztezéséből született, nem számít klasszikusan elfogadott muszlim ruhadarabnak. Ugyanakkor Ahed Zanetti, egy ausztráliai muszlim, kifejezetten azzal a céllal tervezte, hogy a könnyített ruhadarab, betartva az iszlám által megkövetelt szemérmességet, elősegítse a muszlim nők sportolási tevékenységét azzal, hogy csupán az arcot engedi láttatni.

181 A Tribunal Administratif de Nice 1603508 és 1603523 számú döntései. http://nice.tribunaladministratif.fr/content/download/69800/641111/version/1/file/1603508\%20et $\% 201603523 \% 20 \% 20$ référé $\% 201 \mathrm{li}$ berté\%20plages\%20Villeneuve-Loubet.pdf (letöltés dátuma: 2019. 09. 29.)
} 
intenzitása és brutalitása rendkívüli módon megosztotta a francia társadalmat, továbbá jelentős mértékü érzelmi turbulenciát váltott ki az emberekből.

A nizzai fellebbviteli bíróság mérlegelte, hogy a ruházat az egyének önkifejezésének egyik eszköze, s ezen belül is különösen a vallásos elkötelezettséget kifejező ruházat meghatározó lehet az egyén számára az öt másokkal összekapcsoló vagy megkülönböztető szerepe miatt. Sokan ezt önszántukból, vallásos meggyőződésből teszik. Ugyanakkor, a bíróság kifejezte azon álláspontját is, hogy az iszlámon belül a nemek között érvényesülö, a ruházatban is megnyilvánuló megkülönböztetés nem egyeztethető össze az alkotmány által megkövetelt nemi egyenjogúság alapelvével. A nőkkel szemben megvalósuló diszkrimináció, legyen az akár csak az öltözködésben kifejezett is, nem fogadható el a bíróság szerint egy demokratikus társadalomban és szembe megy a francia társadalom alapvető értékeivel. Végül, a bíróság elfogadta Villeneuve-Loubet településének azt az érvelését, hogy a vallási ruházat viselése egy szekuláris államban a radikális vallási nézetekkel is azonosítható a külső szemlélő számára. Ez egyfelől, más fürdőzők vallásos meggyőződésével vagy ennek hiányával szemben lehet ellenséges, másfelöl viszont a közelmúltban elkövetett terrorcselekményekre tekintettel másokban bizalmatlanságot okozhat vagy esetleg provokációnak tekinthetik a viselt ruházatot. Ezért a bíróság kimondta, hogy a fürdőzőhelyek használatát továbbra is a vallási semlegesség kell, hogy meghatározza.

A közigazgatási bíróság döntését a felperesek megfellebbezték, így végül az ügyben a jogerős döntést a Conseil d'État ${ }^{182}$ hozta meg 2016. augusztus 26-án. A testület figyelembe vette, hogy jogszabály elfogadása előtt az önkormányzat társadalmi vitát is folytatott az ügyben, amely visszaigazolta a szabályozás célját a vallási öltözékek betiltását illetően. Franciaországban a helyi önkormányzatok esetében a polgármester irányítja a prefektus adminisztrációját, illetve annak részeként a települési rendőrséget. ${ }^{183}$ A települési rendőrség felel a közrendért, a közbiztonságért és a köztisztaságért. ${ }^{184}$ A törvény felhatalmazza továbbá a polgármestert, hogy szabályozza a fürdést és minden partról folytatott vízi tevékenységet. ${ }^{185}$ A polgármester kizárólag célhoz kötötten és arányosan korlátozhatja a jogszabályi keretek között a fürdőzőket

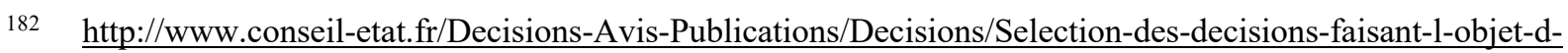
une-communication-particuliere/CE-ordonnance-du-26-aout-2016-Ligue-des-droits-de-l-homme-et-autresassociation-de-defense-des-droits-de-1-homme-collectif-contre-1-islamophobie-en-France

${ }^{183}$ A helyi önkormányzatokról szóló törvény 2212-1 cikke alapján (letöltés dátuma: 2019. 09. 29.)

${ }^{184}$ Uo. 2212-2 cikk alapján

${ }^{185}$ Uo. 2212-3 cikk alapján
} 
megillető szabadságjogokat. Ahhoz, hogy például a fürdőzéssel kapcsolatban korlátozásokat vezethessen be a polgármester, a korlátozással érintett magatartásnak bizonyíthatóan kihatással kell lennie a közrendre. A Conseil d'État által elvégzett vizsgálatok ${ }^{186}$ nem tártak fel közvetlen összefüggést a közrend veszélyeztetése és a fürdőhelyeken folytatott gyakorlat között. A testület egyértelmüen kimondta, hogy a közmeghallgatás formájában lefolytatott társadalmi vita nem felel meg a közrendi feltételnek. A döntés szerint Villeneuve-Loubet önkormányzata nem köteles megtéríteni a felperesek eljárási költségeit tekintettel az ügy kivételes körülményeire. Hogy melyek ezek a kivételes körülmények pontosan, csak következtetni tudunk, ugyanis a döntés nem részletezi jobban. Vélhetően ebben a szófordulatában a Conseil d’État megemlékezik a Franciaországot ért súlyos terrortámadás-sorozatról, ugyanakkor az ítélet fényében azt nem tekinti kellően meghatározónak a joggyakorlat igazításához.

A Conseil d'État döntésével hatályon kívül helyezte a nizzai közigazgatási bíróság 2016. augusztus 22-ei döntését. Villeneuve-Loubet polgármesterének 2016. augusztus 5-én kelt rendelete 4.3 pontjának alkalmazását felfüggesztette. Villeneuve-Loubet települése, mint alperes, valamint az Emberi Jogi Liga és a Franciaországi Iszlamofóbia Ellen Az Emberi Jogokért Egyesület, mint felperesek további kérelmeit elutasította a testület. Végül, Conseil d’État meghatározta, hogy a döntését a peres feleken kívül a belügyminiszter is megkapja tájékoztatásul.

A Conseil d’Etat döntésének üzenete egyértelmü: visszatérni a normálishoz. A normális jogi értelemben véve a települési önkormányzat rendeletének megsemmisítését jelenti (eredeti állapot helyreállítása), ugyanakkor arra a mélyen gyökerező társadalmi problémára, amelyet a Franciaországot sújtó sorozatos terrortámadások hoztak a felszínre és amelynek csak tünete Villeneuve-Loubet önkormányzatának éppen tárgyalt rendelete, nem kínál semmilyen megoldást a jogerős döntés. Persze az is igaz, hogy a bíróságnak nincs közvetlen szerepe a társadalmi problémák megoldásában, erre a kormánynak van felelős jogköre. A bíróság ítéletei mindazonáltal nem egy esetben reflektálnak arra a társadalmi valóságra, amelyben születnek.

\footnotetext{
186 A Conseil d’État részére a nizzai közigazgatási bíróság 2016. augusztus 22-i (hétfői) döntése nyomán a felperesek fellebbezése leghamarabb másnap, 2016. augusztus 23-án (kedden) érkezhetett meg. Mivel a testület már 2016. augusztus 26-án (pénteken) ismertette a döntését, nyilvánvaló, hogy a vizsgálatokat két nap alatt, 2016. augusztus 24-25. (szerda-csütörtök) között végezték el. Az ilyen határidőkkel lefolytatott eljárás két dolgot jelenthet: (1) az ügy teljesen nyilvánvaló volt, kétség nem fér a döntés megalapozottságához, vagy (2) a döntés jogpolitikai célzatú és az egységes jogértelmezést segíti elő.
} 
Még akkor is, ha ez egyértelműen kihat a jogértelmezésre. ${ }^{187}$ A Conseil d'Etat döntése türelmet kér a társadalomtól és ennek érvényre juttatását várja el a hatóságoktól. Ugyanakkor a bíróság joggyakorlata nem képes lépést tartani azokkal az időnként indulatba átcsapó érzelmekkel, amelyeket viszont a politika dinamikája könnyüszerrel kiaknáz. Ez egyértelmüen látszik a francia választók kiábrándultságában, amelynek eredményeképpen az elnökválasztás döntőjében a szélsőjobboldali radikális jelölt indult a centrista, szinte semmiből jövő, új jelölttel szemben. Közel két év különleges jogrend és a katonák látványa az utcákon nem kielégítő válasz arra, hogy Franciaország az iszlámista terrorizmus kiemelt célpontja. A franciák ezt hosszútávon láthatóan nem tolerálták.

Egy másik ügyben a marseille-i fellebbviteli közigazgatási bíróság helyben hagyta ${ }^{188}$ a bastiai közigazgatási bíróság döntését, amely jogszerünek találta a burkini betiltását Sisco település strandjain. A korzikai Sisco település polgármestere 2016. augusztus 16-án hozott rendelete értelmében a vallási elköteleződés kinyilvánítására alkalmas ruházatot viselők strandhasználati jogait 2016. szeptember 30-ig korlátozta az önkormányzat. A polgármester döntését az Emberi Jogi Liga megtámadta, azonban keresetüket a bastiai közigazgatási bíróság 2017. január 26-án elutasította.

A marseille-i fellebbviteli közigazgatási bírósághoz 2017. március 29-én érkezett be az Emberi Jogi Liga fellebbezési kérelme, illetve 2017. május 18-án egy memorandum az előbbi kiegészítésére. A település jogi képviselője arra hivatkozott, hogy 2016. augusztus 13-án (szombaton) a település ún. Marine részében, amely javarészt egy tengerparti strandból áll, észak-afrikai származású családok és nagyjából 40 fő helyi összetüzésbe keveredett. Az összeszólalkozást egyre eszkalálódó tettlegesség követte, amelyet a Compagnies Républicaines de Sécurité ${ }^{189}$ és a Gendermarine nagyjából 100 tagja tudta csak megfékezni. A rendőri fellépés mértékére azért volt szükség, mert a feldühödött tömeg több gépjármüvet felgyújtott, 5 személy kórházba került és a 3 észak-afrikai család meglincselésének a követlen veszélye állt fenn.

\footnotetext{
187 Jørgen DALBERG-LARSEN: Alf Ross and the Sociology of Law. Stockholm Institute for Scandinavian Law, 2010., pp. 43-46.

${ }^{188}$ A Cour Administrative d'Appel de Marseille 17MA01337 számú döntése

http://marseille.cour-administrative-

appel.fr/content/download/104768/1049245/version/1/file/17MA01337\%20arrêt.pdf (letöltés dátuma: 2019.09. 29.)

${ }^{189}$ A francia rendőrség speciális rendvédelmi feladatokat ellátó szervezete, amelyet kifejezetten a különféle zavargások, lázadások, erőszakos tüntetések stb. elleni fellépésre hoztak létre 1944-ben.
} 
Az incidenst követő napon történt nagy szabású demonstrációt szintén könnygázzal kellett feloszlatnia a hatóságoknak. Mindezek alapján a marseille-i fellebbviteli közigazgatási bíróság 2017. július 3-án kelt döntésében szintén helyben hagyta az Emberi Jogi Liga keresetének elutasítását. 


\subsection{A félelem hatása a nemzetközi kapcsolatokra}

A félelem mint egyéni és közösségi szinten értelmezhető és valamilyen cselekvésre motiváló tényező befolyással van az állami szintü jogalkotásra és a nemzetközi kapcsolatokra. A nemzetközi kapcsolatokat meghatározó (objektív) nemzetpolitikai megfontolások mellett a (szubjektív) egyéni preferenciák is szerepet játszanak. ${ }^{190}$ Az egyének mellett természetesen az államoknak is vannak saját érdekeik, amelyek kihatnak a felelősségre vonáshoz kapcsolódó jogértelmezésre ${ }^{191}$ - hiszen pl. az állam saját ügyében nem igazán mondható pártatlannak ${ }^{192}-$, illetve léteznek olyan, az államok által kollektív módon elismert érdekek (hostes humani generis), amelyek az egész emberiség együttélése szempontjából elengedhetetlenek. ${ }^{193}$

A terrorizmus jelenségét nem vizsgálhatjuk egyszerűen egy érdekelmélet alapján, mert önmagában az érdekelmélet pont azoktól a szempontoktól fosztják meg a vizsgálatot, amelyek adott esetben a differentia specificát jelentik. Fennáll a veszélye ugyanis annak, hogy az ideológiai és dogmatikus alapok eltávolításával, valamint a kitüzött (politikai) célok lecsupaszításával lényegében arra a következtetésre juthatunk, hogy az állam és a terroristák között csak a fegyverek minősége és ereje alapján tudunk különbséget tenni. A nemzetközi jog és az alkotmányjog által kidolgozott értékek kell, hogy kiadják azt a vonalvezetőt, amely a terrorizmus hatásainak jogtudományi értékelésénél a jogállami eszmékből és értékekből álló monolit tömböt, mint viszonyítási pontot jelentik. Ugyanakkor, a terrorizmussal kapcsolatos nemzetközi jogi problémakör politikai és (tisztán) jogi szempontjait nem lehet teljes mértékig külön választani, hiszen a jogi vetület akkor is megjelenik egy konfliktushelyzetben, ha egyébként a lényegét nem a jogi elem szolgáltatja. ${ }^{194}$ Jelen fejezetben a nemzetközi kapcsolatok egyik katalizátoraként értelmezem a félelmet. Tálas Péter a nemzetközi hatalom értelmezésekor

\footnotetext{
${ }^{190}$ Stephen, DYSON: Cognitive Style and foreign policy. In International Political Science Review 2009/1., pp. 3348.; Bernd, SCHLIPPHAK, Timo, MeniKKen: Assessing attitudes towards regional integration processes. In: Philippe, De Lombaerde, Renato, FlôRes, Lelio, IAdPadre, Michael, Schulz: The Regional Integration Manual. Quantitative and Qualitative Methods. 1st Edition. Routledge 2012, pp. 24-50.; Astrid, CARRAPATOSO, Bernd, SCHLIPPHAK: Bringing the individual back in. International Relations and the First Image. European Consortium for Political Research Workshop, https://ecpr.eu/Filestore/WorkshopOutline/57a30dce-9041-4887bef0-4994705978c2.pdf (letöltés dátuma: 2019. 09. 29.); Hans J., MorgenthaU: Politics Among Nations. The Struggle for Power and Peace. 7th Edition., McGraw-Hill Education 2005., pp. 3-18.

191 ÂDÁNY Tamás Vince: A Nemzetközi Büntetöbiróság joghatósága. Elözmények, tendenciák és elöfeltételek. Pázmány Press, Budapest 2014., p. 19.

${ }^{192}$ KARDOS Gábor: Carl Schmitt és az államközi konfliktusok kérdése. In: Iustum Aequum Salutare 2012/1., p. 49. (a továbbiakban: KARDOS)

${ }_{193}$ ÁDÁNY, p. 69., 141.

${ }^{194}$ KARDOS, p. 50.
} 
megkülönbözteti a gazdasági, diplomáciai, kulturális és katonai hatalmat. ${ }^{195}$ A hatalom értelmezéseivel kifejezésre jutó jelenséget, ha érzelmi összefüggéseit vizsgáljuk, illetve jogalkotási folyamatábrán helyezzük el, láthatóvá válik a hatalom és a félelem közötti korreláció. Hiszen, a két jelenség nagyon hasonló hatást vált ki, politikai és jogi következményeik sok esetben meg is egyeznek. Azonban, minden hasonlóság ellenére, a két jelenség igen kontrasztos érzelmi státuszból gyökerezik és így - nem feltétlenül és nem minden esetben, de - éppen ellentétes jogi és politikai reakciókhoz vezethet.

Az alábbiakban azt vizsgálom a kutatás részeként, hogy milyen szinteken jelenik meg ez a félelemtől való befolyásoltság, illetve a különféle forrásokból jelentkező, de azonos fókuszponttal (terrorizmus) rendelkező félelmek, hatásaikat tekintve is különbözőséget fognake eredményezni vagy a félelem lecsapódásakor elveszíti sajátos jellegét.

195 TÁLAS Péter: A nemzetközi hatalmi viszonyok változása, geopolitikai következmények. In: FINSZTER Géza, SABJANICS István (szerk.) Biztonsági kihívások a 21. században. Dialóg-Campus, Budapest 2017., p. 17. 


\subsubsection{A félelem belsô eredetű hatásai a nemzetközi kapcsolatokra}

A vélt vagy valós veszélytől való félelem részbeni átvételére teremtenek lehetőséget az államok közötti nemzetközi kapcsolatok. Vagyis hiába keletkezik csupán az egyik társadalomban a félelem, ezt egy másik direkt vagy indirekt módon képes transzplantálni ${ }^{196}$ a saját keretei közé. Ennek egyik oka a politikai interpretáció ${ }^{197}$ amely során a nemzeti politika ${ }^{198}$ egy másik állam, illetve társadalom életét befolyásoló félelmet beemel a politikai diskurzusba. Ezzel a közbeszéd részévé teszi a félelmet és valamennyi politikai szereplő számára igazodási pontként jelöli ki a továbbiakban. Szemléltető példa erre, ha a nemzetpolitikai stratégiát olyan bekövetkezett negatív eseményre tekintettel alakítják, amely valójában nem érintette közvetlenül az államot, de felkészülve annak esetleges jövőbeni újabb előfordulására, felülvizsgálják a hatályos stratégiákat. Miután Észtország fóvárosában, 2007-ben áthelyeztek egy szovjet-időkből megmaradt emlékmüvet, az észt központi államigazgatás internetes felületei és a bankrendszer elektronikus szolgáltatásai 22 napon keresztül korlátozottan tudtak csak szolgáltatást nyújtani, illetve átmenetileg elérhetetlenné váltak egy koncentrált hacker tevékenység miatt. Ez arra vezette a jogalkotót, hogy az észt nemzetbiztonsági stratégiát 2011-ben felülvizsgálja és abba, túllépve a hagyományos katonai kereteken, beemelje a civil társadalmat és a piaci szereplőket is. ${ }^{199}$ A nemzetbiztonsági stratégia egy átfogó, számos állami érdeket és politikát magában foglaló mü, amelynek célja, hogy kijelölje egy állam legfontosabb kül- és biztonságpolitikai célkitüzéseit, pozícionálja az államot a regionális és globális nemzetközi dimenzióban és vonalvezetőként segítse a kormányt az állam biztonságáért végzett tevékenységében.

\footnotetext{
196 A transzplantáció kifejezést elsőként a terrorizmussal kapcsolatos párhuzamos jogalkotásra az amerikai alkotmányjogász Laura Donohue használta. Ö jogalkotási klónozásokat, konkrét jogtechnikai megoldások átvételét elemezte, kifejezetten az Egyesült Államok és az Egyesült Királyság jogrendszerében. Jelen kutatás vonatkozásában viszont nem (csak) a konkrét jogalkotási termék alakisága alapján vonok párhuzamot, hanem a jogalkotás okaként jelentkező anyagi jogforrást vizsgálom (értsd: a biztonságérzet, mint társadalmi szükséglet ellentéte a félelem). Vö. DONOHUE, pp. 67-87.

197 Aurel, SARI: Blurred Lines: Hybrid Threats and the Politics of International Law. European Centre of Excellence for Countering Hybrid Threats. 2018., https://www.hybridcoe.fi/wpcontent/uploads/2018/01/Strategic-Analysis-2018-1-January-Sari.pdf (letöltés dátuma: 2019. 09. 29.); Holger, STRITZEL: Security as a translation: Threats, Discourse, and the Politics of Localisation. In: Review of International Studies 2011/5., pp. 2491-2517

${ }^{198}$ Célszerübb az államok közötti nemzetközi politikától megkülönböztetni az államon belül érvényesülő nemzeti politikát, mint utóbbit egyszerüen belpolitikának nevezni, amelyet könnyen redukálhatunk így belügyekre. Fontos szerepet játszik az állam belső politikai viszonyrendszerében a nemzeti politikának a nemzetközi eseményekre adott reflexiója.

${ }^{199}$ Viljar, VEEBEL, Illimar, PLOOM: Estonia's comprehensive approach to national defence: origins and dilemmas.

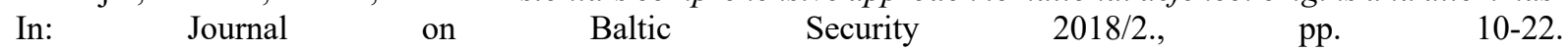

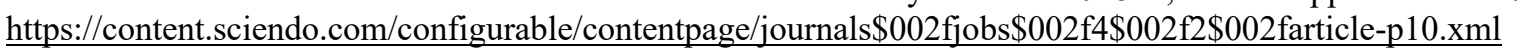
(letöltés dátuma: 2019.09. 29.)
} 
A félelem transzplantálásának másik meghatározó oka a politikai érdekekben ${ }^{200}$ keresendő. A politikai érdekeken belül megkülönböztethetünk nemzeti politikához, pártpolitikához, valamint politikusok személyes ambícióihoz kötődő érdekeket. ${ }^{201}$ A politikai versenyben résztvevő politikusok és szervezetek legitim politikai érdeke, hogy támogatottságot szerezzenek és azt meg is tartsák. ${ }^{202}$ A nemzeti politikában mindezek szintézise megy végbe. A politikai interpretációt és a politikai érdeket mint a félelem átvételének belső megalapozottságú eszközét egymásra tekintettel tudjuk elhatárolni. A két szempont valójában ugyanannak az éremnek a két oldala, és leginkább korrelatív módon tudjuk megmondani, éppen melyik eset áll fenn. Vagyis, ha nem valamely politikai érdek dominanciája alapozta meg a félelem átvételét a nemzetközi kapcsolatokon keresztül, akkor beszélhetünk a politikai interpretáció szükségszerüségéről.

A tisztán politikai megalapozottságú interpretáció mellett megjelent a jogpolitikai interpretáció is, vagyis, amikor a harmadik államban elkövetett terrortámadás vált ki valamilyen belső jogi reflexiót. Mindez persze a belső jog és a nemzetközi kapcsolatát vizsgálva a szuverenitás korlátjaként tudható be. ${ }^{203} \mathrm{Az}$ Egyesült Államok 1986-os törvénye, ${ }^{204}$ illetve az Egyesült Királyság 2001-es törvénye ${ }^{205}$ tett kísérletet arra, hogy az állampolgárai sérelmére harmadik államban elkövetett terrorcselekmény feltételezett elkövetőit felelősségre vonhassák. Mindkét esetben korlátozott sikereket értek el az államok, illetve a mégis eredményes felelősségre vonás többnyire egyéb körülményeknek is köszönhető volt. ${ }^{206}$

\footnotetext{
200 BIHARI, pp. 17-20., 45-46.

201 Stephen A., Meserve, Daniel, Pemstein, William T., Bernhard: Political Ambition and the Legislative Behavior in the European Parlieament. In: The Journal of Politics 2009/3., pp. 1015-1032.

202 POKOL, pp. 106-108., 170-174.

${ }^{203}$ KARDOS Gábor: Az államok szuverén egyenlösége. In: JAKAB András, FEKETE Balázs (szerk.) IJOTEN ( Internetes Jogtudományi Enciklopédia) Nemzetközi jogi rovat (rovatszerkesztő: Sulyok Gábor) 2018 [32] https:/ijoten.hu/uploads/az-allamok-szuveren-egyenlosege.pdf (letöltés dátuma: 2019. 09. 29.)

${ }^{204}$ Jon C., Cowen: The Omnibus Diplomatic Security and Antiterrorism Act of 1986: Faulty Drafting May Defeat Efforts to bring Terrorists to Justice. In: Cornell International Law Journal 1988/1., pp. 127-146.

${ }^{205}$ Clive, WALKER: Human Rights and Counterterrorism in the UK. Az ENSZ Emberi Jogi Főbiztossága számára készített tanulmány 2016., p. 32.

${ }^{206} \mathrm{Pl}$. az érintett harmadik állam szerveivel együttmüködve végrehajtott katonai és nemzetbiztonsági akciók.
} 


\subsubsection{A félelem külső eredetü hatásai a nemzetközi kapcsolatokra - A közös kulturális alapok}

Az államok közötti diplomáciai kapcsolatokon keresztül az államok - kormányok - politikai motivációi befolyással vannak egymásra. Erre csak ráerősít a hagyományos média és különösen a közösségi média, amelyek nincsenek tekintettel az országhatárokra, és természetes csatornaként szolgálnak az információ közvetítése és az információ sajátos interpretálása során. A társadalmat, illetve a politikai diskurzust befolyásoló félelem abban a társadalomban jelenik meg legkönnyebben, amely a legtöbb hasonlóságot hordozza. Tipikusan ilyen lehet a közös történelmi múlt, a kulturális hagyományok és különösen a nyelvi egyezés, amelyek kiváló platformot biztosítanak a félelem és általában a legtöbb politikai vélemény átvételére és átadására, vagyis transzplantálására. ${ }^{207}$ Ilyenkor egyebek mellett, nem müködik az a természetes szürő, amely a nyelvi-kulturális különbözőség miatt meglévő „mi és ők” megkülönböztetésből fakad.

A legeklatánsabb példa erre a 2001. szeptember 11-ét követő általános megrendülés és határozott kiállás az Egyesült Államok mellett az angolajkú országok részéről. Ez az Egyesült Királyság és Ausztrália esetében az Afganisztáni háborúban való részvételt is jelentette. Hasonló jelenségek voltak tapasztalhatók a párizsi terrortámadásokat követően Belgiumban, illetve a brüsszeli támadást követően Franciaországban. Érdekes jelenség, hogy ezzel párhuzamosan, vélhetően a két ország többségi társadalmai között meglévő természetes kapocsra is reflektálva, az iszlámista terrorizmussal összefüggésbe hozott kisebbségek is szorosabb együttmüködést mutatnak. Ilyen intenzitású együttmüködés még azonos kulturális gyökerek esetén sem jellemző a más országokban élő bevándorló csoportok között, éppen a többségi társadalom eltérő jellegzetességei miatt.

Egy másik példa erre az ún. nordic exceptionalism, amely a skandináv országokra jellemző. Négy okra szokás visszavezetni: (1) az erős protestantizmusra, (2) a fejlett országokhoz képest is jelentős gazdasági teljesítményre, (3) az alacsony korrupcióra, valamint (4) a társadalmi egyenlőség (etnikai és gazdasági értelemben véve egyaránt), amelyek regionális szempontból nézve is sajátos jellemzők. Utóbbi kettő a skandináv országok esetében kulturális sajátosságnak

${ }^{207}$ DONOHUE, pp. 67-87. 
is betudható. ${ }^{208}$ Nehéz besorolni a skandináv együttmüködést abból a szempontból, hogy a közös katonai védelemre a NATO keretein kívül hivatalosan nincs lehetőség, hiszen nem írtak alá az államok erről szóló nemzetközi szerződést. Ugyanakkor azt már a 2008-as orosz-georgiai nemzetközi fegyveres konfliktus idején is megállapították a skandináv államok, hogy egyikük ellen folytatott katonai agresszió olyan mértékben lenne kihatással a többiekre, hogy nagy valószínűséggel a skandináv államokkal csoportosan kell számolni egy nemzetközi fegyveres konfliktus esetében. ${ }^{209}$

${ }^{208}$ Jan DeLhey, Kenneth Newton: Predicting Cross-National Levels of Social Trust: Global Patterns of Nordic Exceptionalism. In: European Social Review 2005/4., pp. 311-327.

${ }^{209}$ Tore, NYHAMAR: A future Nordic alliance. Prerequisits and possible operations. Norwegian Defence Research Establishment 2019, p. 26. 


\subsubsection{A félelem külső eredetű hatásai a nemzetközi kapcsolatokra - Az empátia ${ }^{210}$}

A nemzetközi közösséget összetartó alapelvek és a nemzetközi szerződések - kimondatlanul is - elsődlegesen az államok békés együttműködését és a nemzetközi biztonságot helyezik a fókuszpontba. Ahogyan ez megjelenik az ENSZ Alapokmányának 1. cikkében is: a nemzetközi szervezet elsődleges célja a nemzetközi béke és biztonság megteremtése és megőrzése. Az elsődleges célhoz kapcsolódóan az ENSZ Alapokmánya alapvetően passzív magatartást ír elő a tagok számára, amely az erőszaktól való tartózkodást várja el. A jogszerü aktív fellépéshez szükséges a Biztonsági Tanács határozata, a veszélyek kezelésével kapcsolatban azonban már számos szervezet rendelkezhet kompetenciával: az ENSZ ún. kéksisakos békefenntartókat is toborozhat a tagállami hadseregekböl, megbízhat egy tagállamot vagy egy nemzetközi katonai szervezetet a biztonság megteremtésére. A nemzetközi béke és biztonság érdekében történő katonai fellépés ugyanakkor nem egyezik meg az államok közötti esetleges szolidaritási kötelezettséggel. A szolidaritási kötelezettség nem jelenik meg az ENSZ Alapokmányában, azonban az európai uniós alapszerződésekben igen, mi több, számos jogintézmény egyik alapjaként utalnak a szolidaritásra. A szerződéses kötelezettségként jelentkező szolidaritás nem egyenlő az itt tárgyalt empátiával. Varga Zs. András és Schanda Balázs a nemzeti identitás egyik alapvető eszközének tekintik a szolidaritási közösséget. ${ }^{211}$ A nemzetközi kapcsolatok legújabb kori történelme azt mutatja, hogy az elsősorban a nemzetre jellemző kockázatközösség és kritikus helyzetekben megvalósuló áldozatvállalás a politikai, gazdasági vagy más szövetségtöl függetlenül is megvalósulhat.

A félelem természetes, áttétes megjelenése helyett tudatos politikai szerepvállalásról és így átvételről van szó, ha a félelem által meghatározott másik társadalommal korlátozott vagy teljes mértékben sorsközösséget vállalnak mások. Vagyis az államközi és kormányközi együttműködéstől megkülönböztethetők azok a fellépések, amelyek alapját nem valamilyen nemzetpolitikai célhoz köthetjük, hanem egyértelmüen a társadalmi kezdeményezések körébe sorolhatók. Mivel jellemzően természeti csapásokkal vagy balesetekkel összefüggésben kialakult humanitárius katasztrófák kezelésére és a károk enyhítésére jelentkeznek az

\footnotetext{
210 Stephen M., WALT: „Empathy” and international affairs. In: Foreign Policy 27. May 2009 https://foreignpolicy.com/2009/05/27/empathy-and-international-affairs/ (letöltés dátuma); más megközelítésben lásd KARDOS Gábor: A szolidaritás határai. In: Liget: Irodalmi és ökológiai folyóirat 2008/3., pp. 90-95. https://ligetmuhely.com/liget/a-szolidaritas-hatarai/ (letöltés dátuma: 2019. 09. 29.)

${ }^{211}$ VARGA Zs. András: Alkotmányunk értékei. A fogalmi keretek. In: Iustum Aequum Salutare 2009/1., pp. 89107.; Schanda Balázs: Globalizáció és nemzeti identitás. In: (Csink Lóránt, ScHANDA Balázs, szerk.) Összehasonlító módszer az alkotmányjogban. Pázmány Press, Budapest 2017., p. 41.
} 
önkéntesek, ${ }^{212}$ a felajánlásokat hitelesnek és őszintének érzik a bajba jutott kormányok. Ugyanakkor előfordulhat az is, hogy társadalmi vagy nemzetközi nyomás hatására a bajban lévő állam kormánya elutasítja a nemzetközi felajánlást. ${ }^{213}$

${ }^{212}$ Az elmúlt évek néhány jelentősebb magyar felajánlása a teljesség igénye nélkül: a 2018-ban barlangban rekedt thaiföldi focicsapat kimentése, a 2004-es Indiai-óceánon bekövetkezett cunami - első sorban - indonéziai pusztítását követő mentés és helyreállítás, vagy a Magas-Tátra pusztulását követő helyreállítási munkák stb.

${ }^{213}$ A nigériai kormány társadalmi és nemzetközi nyomásra elutasította a brit kormány felajánlását a Boko Haram által elhurcolt diáklányok kiszabadítására, ugyanis elégtelennek tartották, hogy Afrika egyik leggazdagabb és legnépesebb országa képtelen legyen önállóan fellépni a terrorizmus ellen.

https://www.theguardian.com/world/2017/mar/04/nigeria-declined-uk-offer-to-rescue-chibok-girls $\quad$ (letöltés dátuma: 2019. 09. 29.) 


\subsubsection{A félelem külső eredetú hatásai a nemzetközi kapcsolatokra - A politikai szövetség}

A nemzetközi kapcsolatokat írott és íratlan szabályok sora határozza meg, amelyek legjellemzőbb eszköze a nemzetközi szerződés. A nemzetközi szerződés tárgya szinte bármi lehet, amely nem ütközik ius cogens normákba, de többségében azért gazdasági és katonai tárgyú szerződéseket kötnek az államok egymással. ${ }^{214}$ Két vagy több állam egymással fennálló - nemzetközi - kapcsolatát a szerződés tárgyában alapvetően a szerződés és az alkalmazásához kapcsolódó gyakorlat határozza meg. Ebből következik az is, hogy nemzetközi szerződés alkalmazásával a kormányok politikai motivációja és intézkedései legalább egy szűk keresztmetszetben biztosan találkozni fognak, amely így egyfajta hidat képezhet a félelem államok közötti transzferjéhez. Marokkó déli határának nagyrésze sivatagos, amelynek teljes körü határvédelmi ellenőrzése szinte lehetetlen. A két spanyol enkláve Ceuta és Melilla, az afrikai kontinensen korábban vámmentes területnek számítottak, azonban Spanyolország 1986os csatlakozását követően ezen státuszukat fel kellett adniuk. Ma a két terület ugyanúgy a schengeni övezet része, mintha a kontinentális Spanyolországban lennénk. ${ }^{215}$ Ezért az Európai Unió és Marokkó által kötött megállapodás ${ }^{216}$ rendelkezik az enklávék védelméről is, amelyet részben Marokkó vállal. Ez azt jelenti, hogy a spanyol fél által emelt fizikai határvédelem mellett, a marokkói hatóságok is építettek hasonlókat, sőt Marokkói oldalon a hadsereget is bevetették a hatékonyabb védelem érdekében. Összegezve: a marokkói fél nemzetközi szerződés alapján, saját államán belül, Spanyolország, egy szerződő fél államhatárát védi hatósági és katonai eszközökkel a szubszaharai migrációtól. Ezen az a tény sem változtat, hogy a 0,15 $\mathrm{km}^{2}$-es és egyébként csupán néhány kecske által lakott spanyol fennhatóságú Petrezselyem-sziget elfoglalására Marokkó legutóbb 2002-ben tett kísérletet, amelyet a spanyol királyi haditengerészet akadályozott meg. ${ }^{217}$ Hiszen az Európai Unióval kötött kereskedelmi együttműködésből Marokkónak jelentős anyagi haszna származik. ${ }^{218}$

\footnotetext{
${ }^{214}$ A nemzetközi szerződések tárgy szerinti csoportosítására ld. BRUHÁcs János: A nemzetközi jog tegnap és ma. In: Állam- és Jogtudomány 2013/3-4., pp. 9-23.

215 Jamie, TRINIDAD: An Evaluation of Morocco's Claims to Spain's Remaining Territories in Africa. In: The International and Comparative Law Quarterly 2012/4., pp. 961-975.

${ }^{216} \mathrm{https}$ ://europa.eu/rapid/press-release IP-18-6705 en.htm (letöltés dátuma: 2019. 09. 29.)

217 Jamie, TRINIDAD: An Evaluation of Morocco's Claims to Spain's Remaining Territories in Africa. In: The International and Comparative Law Quarterly 2012/4., pp. 961-975.

218 https://ec.europa.eu/trade/policy/countries-and-regions/countries/morocco/ (letöltés dátuma: 2019. 09. 29.)
} 


\subsubsection{A félelem külső eredetű hatásai a nemzetközi kapcsolatokra - A katonai szövetség}

A katonai szövetség valamennyi nemzetközi együttmüködési forma közül a legerősebb, amely egyúttal legszorosabban kapcsolódik a félelem nemzetközi exportjához-importjához, mivel az főszabály szerint ebben az esetben automatikus átvételt eredményez. Tekintettel arra, hogy az ENSZ Alapokmánya 2. cikk 4. bekezdése alapján az államoknak tartózkodniuk kell az erőszakkal való fenyegetéstől, valamint az erőszak alkalmazásától. Ebből következik, hogy a katonai szövetségben lévő államok alapvetően már nem egy támadólagos - tipikusan területszerzésre irányuló - nemzetközi fegyveres konfliktusra tekintettel alakítják ki tartós együttmüködésüket. A katonai szövetségek célja így - összhangban az ENSZ Alapokmányával - sokkal inkább egy elöre nem látható nemzetközi jogi helyzet megoldása, amelyben a szövetség tagjai egy jogellenes erőszak elszenvedői vagy nemzetközi felhatalmazással humanitárius beavatkozást hajtanak végre közösen. A katonai szövetség részeseit megillető jogokat és kötelezettségeket a szövetséget létrehozó nemzetközi szerződés tartalmazza. A megtámadott állam ugyanakkor nem minden esetben gyakorolja a szövetségből fakadó jogait. Ennek többnyire belpolitikai és a nemzetközi kapcsolatokban rejlő okai vannak. Az Egyesült Államok elnökének 2001. szeptember 20-án elmondott kongresszusi beszéde egyszerre volt üzenet az amerikai társadalomnak, az Egyesült Államok szövetségeseinek, valamint a világ minden országának. A helyzetértékelésen túl követeléseket fogalmazott meg Afganisztán tálib kormánya részére, valamint utalt arra, hogy az amerikai kormány kezdeményezte a Washingtoni Szerződés 5. cikkének életbe léptetését. ${ }^{219} \mathrm{Az}$ angol terminológiában csak „afganisztáni háborúként” ismert további események ismertek. Ezzel szemben, amikor sorozatos terrortámadást követtek el az Iszlám Államhoz kötődő személyek és csoportok franciaországi célpontok ellen - és az Iszlám Állam már egyébként is súlyosan veszélyeztette a nemzetközi békét és biztonságot - Hollande francia elnök nem kezdeményezte a Washingtoni Szerződés 5. cikkének életbe léptetését. ${ }^{220}$ Az EUSZ 42. cikk 7. bekezdése valamennyi tagállam számára kötelezően írja elő a megtámadott tagállam segítését és támogatását, ugyanakkor ez

\footnotetext{
${ }^{219}$ George W. Bush beszéde, amelyet 2001. szeptember 20-án tartott a 107. amerikai kongresszus összevont ülésének https://georgewbush-

whitehouse.archives.gov/infocus/bushrecord/documents/Selected Speeches George W Bush.pdf (letöltés dátuma: 2019. 09. 29.)

${ }^{220}$ Francois Hollande beszéde, amelyet 2015. november 16-án tartott Versailles-ban a francia parlament összevont ülésének

https://www.diplomatie.gouv.fr/en/french-foreign-policy/security-disarmament-and-nonproliferation/events/events-regarding-defence-and-security/article/speech-by-the-president-of-the-republicbefore-a-joint-session-of-parliament (letöltés dátuma: 2019. 09. 29.)
} 
nem egyenlő az összehangolt és automatikus katonai fellépéssel, így ez inkább csak egyfajta iránymutatás a tagállamok számára, illetve meghatározatlan tartalmú és mértékü felajánlási kötelezettséget teremt a megtámadott tagállam felé. Az EUMSZ 222. cikkében megfogalmazott ún. Szolidaritási Klauzula alapján viszont mindenképpen érvényesülne valamilyen mértékü automatizmus, továbbá az uniós szervek is kiemelt szerepet kapnának a végrehajtásban és a koordinációban. A francia elnök az EUMSZ 222. cikkének említésétől is tartózkodott. A Szolidaritási klauzula a tagállamok területére vonatkozóan határozza meg katonai vagy más jellegű segítségnyújtást, vagyis a nemzetközi terrorizmus elleni összehangolt fellépésre csak korlátozottan lenne lehetőség uniós szinten. ${ }^{221}$ Egyértelmü és konkrét rendelkezés esetén is úgy tünik, hogy a félelem nemzetközi kapcsolatokra gyakorolt hatása nagyban múlik az államok hajlandóságán, hogy a kérdést nemzetközi szintre helyezzék-e, és ha igen, milyen formában.

${ }^{221}$ KNAPP László: A terrorizmus elleni küzdelem az Európai Unió jogában: A terrortámadásra adandó válasz a szolidaritási és a kollektív védelmi klauzula tükrében. In: BARTKÓ Róbert (szerk.) A terrorizmus elleni küzdelem aktuális kérdései a XXI. században. Gondolat kiadó, Budapest 2019., pp. 119-137.; Lásd bővebben: SABJANICS István: A párizsi terrortámadással kapcsolatos jogi következtetések. In: Szakmai Szemle 2015/4. pp. 156-167. 


\subsection{Megállapítások a félelem jogrendszeri hatásairól}

A terrorcselekmények önmagukban nem okoznak olyan minőségü változást a jogrendszerben, mint a terrorveszély. Vagyis, a terrorcselekmény bekövetkezésének az esélye, illetve az ezt mérlegelő esélylatolgatás messzemenőkig súlyosabb következményekkel ${ }^{222}$ járhat a jogrendszer integritására, mint a terrorcselekmény tényleges bekövetkezése. A terrorfenyegetettség, különösen egy bekövetkezett terrortámadás rendkívül súlyos csapás a társadalmi és az intézményi morálra. Egyszerre okozza a félelemérzet egyik legmagasabb fokát és a kudarc bénító érzését. A terrorizmussal kapcsolatos jogalkotás indokolásában minden esetben a töretlen, közvetlen és súlyos terrorveszélyre hivatkoznak, ${ }^{223}$ amely nem is feltétlenül érinti közvetlenül az államot. ${ }^{224}$

A terrorveszéllyel kapcsolatos félelem kihatással van a gazdaságra, ${ }^{225}$ abból is kiemelten a turizmusra, ${ }^{226}$ az államszervezetre ${ }^{227}$ és a politikusok ${ }^{228}$ mellett a bírákra is jelentős társadalmi nyomást helyez. ${ }^{229}$ Hatásai tehát mindenképpen összetettek, egyidejüleg, párhuzamosan jelentkeznek több jogterületen és ágazatban, ugyanakkor a dominó hatás miatt egyéb területeken is találkozhatunk vele. Mindezek alapján a jelenség értékelését csak komplex megközelítéssel lehet érdemben elvégezni. Szemléltető példa, hogy a tömegközlekedést, mint könnyü célpontot fenyegető terrorizmus hatására az emberek inkább az alternatív

${ }^{222}$ Gondoljunk csak a közösségi média szolgáltatókra vonatkozó törvények megváltoztatására, egyes hatósági eljárások (különösen terrorelhárítási akciók) idejére bevezethető közösségi média használat és Internet hozzáférés korlátozására, a 2017-1510. számú törvényre Franciaországból és Magyarország Alaptörvényének hatodik módosítására. A példák egyike sem olyan formában vagy időpontban vált volna a jogrendszer részévé, ha nincs a 2010-es évek rendkívül intenzív terrorizmusa.

${ }^{223}$ Lásd a 2017-1510 sz. francia törvény indokolását

https:/www.legifrance.gouv.fr/affichLoiPubliee.do?idDocument=JORFDOLE000034990290\&type=expose\&le gislature= (letöltés dátuma: 2019. 09. 29.)

${ }_{224}^{2} \mathrm{~T} / 10416$ sz. iromány https://www.parlament.hu/irom40/10416/10416.pdf (letöltés dátuma: 2019. 09. 29.)

${ }^{225}$ Lásd az OECD 2002-es jelentését https://www.oecd.org/eco/outlook/1935314.pdf (letöltés dátuma: 2019. 09. 29.)

${ }^{226}$ David Mc. A., BAKER: The Effects of Terrorism on the Travel and Tourism Industry. In: International Journal of Religous Tourism and Pilgrimage 2014/1., pp. 58-67.; Eurostat Panorama on Tourism és a Eurostat Year Book Transport fejezeteit a vonatkozó kiadványokban; Dominique, VANNESTE, Petronella, TUDORACHE, Flavia, TEODOROIU, Thérése, STEENBERGHEN: The impact of the 2016 terrorist attacks in Brussels on tourism. In: Belgeo 2017/4. szám., https://journals.openedition.org/belgeo/20688\#text (letöltés dátuma: 2019. 09. 29.)

${ }^{227}$ M. Shansul, HAQUE: Government Responses to Terrorism: Critical Views of their Impacts on People and Public Amdinistration. In: Public Amdinistration Review. Különszám: Democratic Governance in the Aftermath of September 11 2001, pp. 170-180; The Impact of Terrorism on State Law Enforcement. Adjusting to New Roles and Changing Conditions. Final Report 2006. The Council of State Governments, Eastern Kentucky Univeristyhttps://www.ncjrs.gov/pdffiles1/nij/grants/216642.pdf (letöltés dátuma: 2019. 09. 29.)

${ }^{228}$ John Alan, CoHAN: Necessity, Political Violence and Terrorism. In: Stetson Law Review. 2005/2006., pp. 903981.

229 Jørgen DALBERG-LARSEN: Alf Ross and the Sociology of Law. Stockholm Institute for Scandinavian Law. 2010., pp. 43-46. 
megoldásokhoz folyamodnak, mint például a személyautó, a taxi, a motorozás, a biciklizés vagy a séta. ${ }^{230}$ Vagyis, egy terrorcselekménynek komoly közgazdasági hatásai is lehetnek, amellyel nem feltétlenül számolhatunk. ${ }^{231}$

A joggyakorlat rendre megértést és türelmet tanúsít a terrorcselekmény miatt az állami szervek és a lakosság irányába. A 2017. március 22-én, a londoni Westminster hídon elkövetett gázolásos merénylet után 3 hónappal, 2017. június 3-án a London hídon is elkövettek egy hasonló gázolásos merényletet. Az áldozatok hozzátartozói kérték akkor, hogy az MI5 és a rendőrség hanyagságát mondják ki, és állapítsák meg a felelősségét ezeknek a szervezeteknek. Az ebben indított vizsgálatot ${ }^{232}$ 2019. augusztus 2-án jogerősen lezárták, amelyben felmentették a hanyagság vádja alól a hatóságokat, éppen a korábban elkövetett terrorcselekmény és a folyamatos terrorveszély miatti leterheltségre tekintettel. ${ }^{233}$

Az Egyesült Államokban a 2001 negyedik negyedévére megrendelt közvéleménykutatást el kellett halasztani a 9/11-es terrortámadás miatt, s csupán 2002 januárjában végezték el annak érdekében, hogy az egész amerikai társadalmat sújtó letargia ne eredményezzen végül fals kimutatást. ${ }^{234}$ Franciaországban a Charlie Hebdo elleni támadást követően látványosan megnőtt a társadalmi támogatottsága a francia rendőrségnek, amely egyébként a francia közintézmények közül az egyik legalacsonyabb. ${ }^{235}$

Jogszabályi rendelkezés nem tiltja, hogy a norvég hatóságok a valós adatok tekintetében a Facebookon vizsgálódjanak egy kérelem elbírálásakor. Ez azonban a pontatlan és irreleváns információk mellett, számos olyan megnyilvánulásnak is a terepe, amelyhez csak törvényben

\footnotetext{
${ }^{230}$ Todd, Litman: Terrorism, Transit and Public Safety. Evaluating the Risks. Victoria Transport Policy Institute. 16. January 2012., https://www.vtpi.org/transitrisk.pdf (letöltés dátuma: 2019. 09. 29.)

${ }^{231}$ Gerd, GIGERENZER: Dread Risk, September 11, and Fatal Traffic Accidents. In: Psychological Science. 2004/4., pp. 286-287.; Bryan W., ROBERTS: The Macroeconomic Impacts of the 9/11 Attack: Evidence from Real-Time Forecasting. Working Paper, US Homeland Security. August 2009, https://www.dhs.gov/sites/default/files/publications/Macroeconomic\%20impact\%209 11\%202009.pdf (letöltés dátuma: 2019. 09. 29.)

${ }^{232}$ Inquests Arising from the Deaths in the London Bridge and Borough Market Terror Attack, lásd https://londonbridgeinquests.independent.gov.uk (letöltés dátuma: 2019.09. 29.)

233 https://londonbridgeinquests.independent.gov.uk/wp-content/uploads/2019/08/Ruling-on-A2-andDeterminations-2.8.19.pdf (letöltés dátuma: 2019. 09. 29.)

${ }^{234}$ Aggravating Circumstances. A Status Report on Rudeness in America. A report from Public Agenda prepared for The Pew Charitable Trusts. 2002 8. oldal https://www.publicagenda.org/files/aggravating circumstances.pdf (letöltés dátuma: 2019. 09. 29.)

${ }_{235} \quad$ https://www.telegraph.co.uk/news/worldnews/europe/france/11341295/French-police-chief-committedsuicide-after-Charlie-Hebdo-attack.html (letöltés dátuma: 2019. 09. 29.)
} 
meghatározott esetekben ${ }^{236}$ lehet köze az állami szerveknek. Ezeknek a szenzitív információknak tulajdonított különös jelentőséget a Norvég Bevándorlási Igazgatóság, amikor a bevándorlási, letelepedési és - főként - a menedékjogi kérelmeket elbírálta. A kérelmek jogszabályban meghatározott alakisággal (rögzített kérdéssorral) rendelkeznek, amely a kérelmek elbírálásához szükséges információkra összpontosít. Vagyis a törvényi minimum ebben az esetben a maximumot is jelenti, hiszen további információkra csak jogszabály felhatalmazása alapján kérdezhet rá a hatóság. A Norvég Társadalomkutatási Intézet jelentésében ${ }^{237}$ bírálta a Norvég Bevándorlási Igazgatóság gyakorlatát, míg utóbbi az Európába érkező bevándorlókkal együtt utazó feltételezett terroristák miatt tartja szükségesnek minden információs adatbázis és forrás felhasználását.

Tehát a terrorizmusnak olyan hatásai is vannak, amelyek értelmezésére a közgazdaságtudomány, a pszichológia és a szociológia képes. Értelemszerűen a jogtudomány sem fordíthat hátat ezeknek a jelenségeknek, azonban - minthogy a szabályalkotáshoz szükséges általánosítást csak túlzó absztrakcióval lehetne elérni - erre leginkább a jogalkalmazás jelenthet megoldást. A norvég bevándorlási hatóság példája azonban rámutat, hogy az alapvető jogokat védő jogszabályi garanciák mellőzésére vagy relativizálására tett gyakorlati lépések aláássák az intézményrendszerbe vetett bizalmat. Az állam és a társadalom biztonság igényét nem lehet patikamérlegen mérni az egyének alapvető jogaival. Rendkívül nehéz dolga van a jogállami intézményeknek, amikor egy különösen nagy biztonsági kihívás miatt gyakorlatilag választaniuk kell a kettő között. Az elmúlt évtizedek európai gyakorlata mégis azt mutatja, hogy a terrorcselekményt követő időszakban tapasztalható egy kilengés, amely tekinthető egyfajta türelmi időnek, azonban bizonyos idő elteltével a jogállami intézmények alapvető feladata és érdeke az lenne, hogy a korábbi garanciális kiegyensúlyozottsághoz visszatérjenek. Ezt pedig az nehezíti, ha a terrorveszély miatt folyamatosan az előbb említett türelmi időt éljük.

\footnotetext{
${ }^{236}$ Tipikusan ilyen a nemzetbiztonsági ellenőrzés (kockázatvizsgálat) és a titkos információgyüjtés (jogellenes cselekménynek és körülményeinek a feltárása).

${ }^{237}$ Jean-Paul, BREKKE, Simon Roland, BRIKVAD, Marta, BivAND ERDAL: Losing the Right to Stay: Revocation of immigrant residence permits and citizenship in Norway - Experiences and effects. Report 2019:9. Institutt for Samfunnsforskning, Oslo. $2019 \quad$ https://samfunnsforskning.brage.unit.no/samfunnsforskningxmlui/bitstream/handle/11250/2599967/Rapport 919 Losing the right to stay Web.pdf?sequence=1\&isAllo wed=y (letöltés dátuma: 2019. 09.29.); vö. BÁNYÁsz Péter: A közösségi média lehetöségei és kihivásai a védelmi szférában. Doktori értekezés 2018., pp. 84-90.
} 


\section{A MILITÁNS DEMOKRÁCIA}

Az államra leselkedő veszélyekre gondolva általában a háború, a polgárháború, esetleg természeti katasztrófa vagy ipari szerencsétlenség jut eszünkbe. Ezek egytől-egyig olyan helyzetek, amelyekre a jogrend nem, vagy nem teljes mértékben képes megfelelő választ adni, ezért biztosítja a kijelölt (vagy külön erre az esetre létrehozott) intézmény számára, hogy a jogrenden kívüli eszközökben is kereshessen megoldást. További közös jellemzője ezeknek a helyzeteknek, hogy a válság nyilvánvaló fizikai jelenléte meghatározó mértékben játszik szerepet. Vagyis a helyzet jogi értelmezésén túl, lényeges szempontot jelent az a fizikai valóság, az a környezet, amely korlátozza vagy kizárja a (rendes) jogrend érvényesülését.

Ez a fizikai jelleg azonban nem minden esetben egyértelmű hírmondója a válságnak. Amennyire nem kívánatos az állami intézményrendszert hatástalanító és a társadalom rendjét felborító jelenség, legalább annyira egyszerü a jogalkotó dolga, amikor a különleges jogrend bevezetésének szabályait erre tekintettel tudja meghatározni. Hiszen a fizikai erőszak nyomasztó terhe mellett azt is jelenti, hogy van egy olyan fogódzója a jogalkotónak, amely egyértelmü, mindenki számára azonos módon értelmezhető keretet ad a különleges jogrend bevezetésének. Másként: a veszély manifesztációja egyértelmű legitimációt nyújt a különleges jogrend számára. A veszély minden egyéb formájának jogi értelmezése nagyban függ az interpretációtól.

A 21. századra újra elökerült a militáns demokrácia fogalma, ${ }^{238}$ amelyet a II. világháború előestéjén alkotott meg Karl Löwenstein, ${ }^{239}$ és amelyről a történelem végével ${ }^{240}$ már azt hittük, meg is feledkezhetünk. Az elmúlt évtizedek terrortámadásainak hatására a militáns demokrácia nem csak, hogy revitalizálódott, de az eredeti elképzeléseket messze meghaladva új jelentéstartalmat is nyert. A militáns demokrácia fogalmába rendkívül széles körből sorolhatunk jogi és egyéb eszközöket. Ezek egy része inkább politikai jellegű, mások igazgatási

\footnotetext{
${ }^{238}$ A militáns demokrácia egy koncepció, amely jelöli mindazon intézkedések, eljárások és jogértelmezések összességét, amelyek a demokratikus jogállamot, különösen annak törékeny politikai rendjét (egyensúlyát) hivatottak megvédeni a veszélytelennek látszó leplezett (politikai) törekvésekkel szemben. A későbbiekben ezzel részletesen foglalkozom.

239 Karl, Loewenstein: Militant Democracy and Fundamental Rights I. In: American Political Science Review 1937/3. (a továbbiakban: LoEwensteIn 1937a), pp. 417-432.; Karl, Loewenstein: Militant Democracy and Fundamental Rights II. In: American Political Science Review 1937/4. (a továbbiakban: LOEWENSTEIN 1937b), pp. 638-658.

${ }^{240}$ Francis, FukUyama: The End of History and the Last Man, Free Press, 1992.
} 
jellegűek. Vannak puhább és vannak keményebb eszközök. A kutatók jelentős része azonban egyetért abban, hogy a militáns demokrácia alapvetően nem lehet ellentétes a demokratikus jogrend alapvető értékeivel. Vannak ugyanakkor, akik egyenesen a kínzás lehetőségével is kacérkodnak. $^{241}$ Továbbá olyanok, akik hajlandók lennének minden alkotmányos korlátot feladni annak reményében, hogy a különleges hatalom gyakorlói később önként lemondanak a közvetlen veszély elmúltával. ${ }^{242}$ Hasonlóan ahhoz, amikor a német birodalmi elnök jóváhagyta a Reichstag épületének leégése után 1933. február 28-án kiadott birodalmi rendeletet. Az akkori jogi környezetben ugyanis nem volt semmi garancia a végrehajtó hatalom kivételes jogosítványainak az időbeli korlátozására. ${ }^{243}$ Holott a különleges jogrendhez hasonlóan, a militáns demokrácia eszközei is csak feltételhez kötötten és így időkorlátok között érvényesülhetnek. Bár inaktív állapotban a jogrend természetes részét képezik. Vagyis szemben a különleges jogrenddel, a militáns demokrácia soha nem terjeszkedhet túl a jogrenden keretein.

A militáns demokrácia kizárólagosan nem kötődik egyetlen jogághoz sem, eszköztára és módszerei ötvözik az állam védelmét szolgáló különféle erösebb és puhább megoldásokat. A büntetőjogi tényállások a militáns demokrácia szempontjából inkább rész-egész viszonyban értelmezhetők, vagy esetleg eszközjellegűek, semmint mellérendelt vagy esetleg párhuzamos megoldásként. Többről van tehát szó, mint az állam társadalmi és gazdasági rendjének védelméről. Sok esetben a militáns demokrácia szemüvegén keresztül nézve veszélyforrásként meghatározott folyamat, az összefüggések szélesebb áttekintése nélkül veszélytelen és összefüggéstelen események sorozatának tűnik. Mivel nehezen behatárolható és képlékeny keretei miatt a diszkrecionális döntéseknek nem csupán teret enged, de nagymértékben épít rájuk. A militáns demokrácia ezért a terrorellenes jogállami intézkedések számára hiteles legitimációt adhat, illetve az elméleti és a gyakorlati megfontolások közötti különbséget hidalhatja át.

Ezért a mai (jog)politikai diskurzusban a militáns demokrácia az egyik legaktívabban tárgyalt kérdéskör. Az évtizedes múlt ellenére látható, hogy az első leközlés óta tett kísérletek egészen

\footnotetext{
${ }^{241}$ Alan M., DERSHOwITZ: Why Terrorism Works? Understanding the Threat, Responding to the Challenge. Yale University Press, New Haven 2003., p. 135.; Oren, Gross: Are Torture Warrants Warranted? Pragmatic Absolutism and Official Disobedience. University of Minnesota Law School, Legal Studies Research Paper Series, Research Paper 2004/4-6., pp. 101-175.

${ }^{242}$ Bruce, ACKERMAN: The Emergency Constitution. In: Yale Law School Legal Scholarship Repository, Faculty Scholarship Series, Yale Law School, New Haven 2004., pp. 1029-1091.

${ }^{243}$ Ingo, MÜLLER: Hitler's Justice. The Courts of the Third Reich. 1 st Edition. Harvard University Press 1992., pp. 46-47.
} 
egyszerủen kizárják az eredeti fogalom mai alkalmazását. A retrospektív szemléletmód segítheti egy olyan fogalom megértését, amely a megalkotása óta eltelt időben nagyban ki volt téve a társadalmi-politikai változásoknak. Az eredeti jelentéstartalmat ebben az esetben a fogalom megalkotásának kora, társadalmi-politikai valóságának, nyelvezetének meghatározottsága alapján vizsgáljuk. A militáns demokrácia 1937-es eredeti jelentésének adaptációjához igen nagy absztrakcióra lenne szükség, amely lényegében megkérdőjelezné az így megújított jelentés autentikusságát. Vagyis célravezetőbbnek látszik, ha az eredeti fogalmat és újragondolásait elkülönítve vizsgáljuk, ugyanakkor az eredeti jelentés és újragondolásai közötti evolutív kapcsolatot el kell ismernünk. 


\subsection{Löwenstein eredeti koncepciója}

Karl Löwenstein az 1930-as évek politikai folyamatait - különösen az első világégés és a gazdasági világválság társadalmi hatásait - észlelve hívta fel a figyelmet a demokráciák militánssá válásának megkerülhetetlen szükségességére. Véleménye szerint a demokráciák jogászi önelégültsége és ezzel egyidejüleg érvényesülő önpusztító letargiája ${ }^{244}$ egy rendkívül káros vegyület, amely a plurális demokráciát könnyü prédává teszi a szélsőséges eszméket hirdető politikai tömörülések számára. Löwenstein néhány év praktizálás után 1931-ben kezdett egyetemen tanítani, azonban már 1933-ban rákényszerült hazája elhagyására a növekvő zsidóellenesség miatt és így átmenetileg nem taníthatott. Az Egyesült Államokban ideiglenesen kapott lehetőséget a Yale Egyetemen, majd állandó státuszt az Amherst College katedráján kapott. $^{245}$

Löwenstein számára az egyik legtermékenyebb időszak a kényszerü emigrációban töltött évek, főleg 1935-1940 között. Írását azonban áthatotta és nagyban meghatározta a személyes tapasztalatokból fakadó pesszimizmus és az antidemokratikus eszmék folyamatos erősödése. Első írásaiban még tartotta az akadémiai objektív távolságtartást, azonban az évtized végére a náci Németország katonai sikereinek hatására és a fasizmus nemzetközi politikai terjedésére - fokozódó intenzitással szólalt fel és egyre határozottabb hangnemet ütött meg, egyre konkrétabban fogalmazott. Tudományos véleménye olyakor a politikai véleménynyilvánítás határát súrolta. A háborút követően az OMGUS ${ }^{246}$ részeként tért vissza hazájába, azonban a győztes államok hazai sajtójának értékelése ellenére rendkívül borúlátónak látta a német társadalom demokratizálódásának folyamatát. ${ }^{247}$

Löwenstein militáns demokráciáról alkotott koncepcióját nem egy egységes írásban alkotta meg, hanem négy különálló müben, amelyekben egymástól némileg eltérő megközelítésben vizsgálta és értékelte az egyes nemzeti megoldásokat, továbbá tett javaslatot újabbakra. Vélhetően nem szándékosságról van szó, de mégis szemléltető módon mutatja be a militáns demokrácia kialakulásának és fejlődésének dinamikusságát az, hogy az Európában akkor

\footnotetext{
${ }^{244}$ LOEWENSTEIN 1937a, p.417, pp. 431-432.

245 https://www.nytimes.com/1973/07/17/archives/karl-loewenstein-amherst-professor.html (letöltés dátuma: 2019.09. 29.)

${ }^{246}$ Office of Military Government, United States [Amt der Militärregierung für Deutschland (U.S.)]

${ }^{247}$ Ben, Plache: Soldiers for Democracy: Karl Loewenstein, John H. Herz, Militant Democracy and the Defense of the Democratic State. Virginia Commonwealth University 2013, p. 52.
} 
győzelemre álló autoriter rezsimekkel kapcsolatos tapasztalatai és a világpolitika eseményei érdemben befolyásolták a militáns demokrácia tartalmára vonatkozó elképzeléseit Löwensteinnek. Egyúttal előre vetíti azt is, hogy a militáns demokrácia nem egy laboratóriumi körülmények között megalkotott képlet, amelyet minden korban és minden társadalomra alkalmazni vagyunk képesek. És itt nem csak annak az alapvetésnek a mentén, miszerint minden (köz)jogi megoldást némileg eltérő módon interpretálnak a nemzeti jogrendben, hanem nyugodtan ide vehetjük a Löwenstein koncepcióját követő évtizedek re-interpretációinak sorát is. Löwenstein hangsúlyozza, hogy a jogszabályok általános objektivitása csak annyiban érvényesül a militáns demokrácia meghatározása során, amennyiben valamilyen szabályokat kell citálni támpontnak, hogy elkerüljük a jogalap nélküli önkény vádját. Egyebekben viszont láthatóan nagy szerepet kap a militáns rendszerek működtetésében az egyéni, eseti mérlegelés, amely az egyes politikai folyamatok és kezdeményezések alkotmányos finomhangolását teszi lehetővé. Ezzel pedig - adekvát keretrendszer nélkül - lehetőséget teremt az önkénynek.

Az Autocracy Versus Democracy in Contemporary Europe két részben közölt 1935-ös cikkében Löwenstein Európa politikai összetételét mutatja be és értékeli, egyúttal ebben az írásában jelenik meg elsőként az a javaslata, hogy a megmaradt nyugati demokráciáknak a politikai stabilitásuk megóvása érdekében érdemi lépéseket kell tenniük. Arra, hogy milyen lépéseknek is kell ezeknek lenni, Löwenstein nem ad konkrét válaszokat. Ekkor még be kell érnünk egyfajta lazán értelmezett tapogatózással. Szerinte a demokrácia-ellenes eszmék további terjedését úgy lehet megakadályozni, az államok egy olyan politikai szisztémát alakítanak ki, amely képes és alkalmas a védekezésre, és amelyet később militáns demokráciaként határoz meg. Már ehelyütt megjelenik pesszimista véleménye, miszerint a demokratikus alapelvek, és különösen az alapvető jogokkal kapcsolatos demokratikus elköteleződés az, amely lehetővé teszi az antidemokratikus mozgalmak politikai hatalomhoz jutását.

Érdekes paradoxona ez a demokratikus rendszereknek. Löwenstein szerint ezek a vezérelvek már nem alkalmasak arra, hogy megvédjék az államot. Szükséges az újra értelmezésük vagy legalább a pontosításuk, kiegészítésük. Löwenstein a tanulmányok megjelenésekor még mindig csak 2 éve kényszerült hazája elhagyására és nagyban meghatározta gondolkodását az antidemokratikus eszmék Európában látott elöretörése és tartós jelenléte a politikai fő sodorban. Mindezek alapján Löwenstein megállapítja, hogy a demokratikus vezérelvek egy részét, 
különösen az alapvető jogok korlátozását akadályozó szabályok egy részét átmenetileg hatályon kívül kell helyezni. ${ }^{248}$

A Militant Democracy and Fundamental Rights címü, szintén két részletben leközölt 1937-es cikkében Löwenstein részletesen elemezte azt, hogyan jutottak el a kizárólagos hatalomgyakorláshoz azok a politikai szélsőségek, amelyek korábban nem tudtak elmozdulni a politika perifériájáról. Milyen kommunikációs, pénzügyi és belső adminisztratív lépéseket tettek annak érdekében, hogy elérjék céljukat. Löwenstein meghatározott különféle lépéseket, amelyeket a demokratikus államok még időben megtehetnek abból a célból, hogy elkerüljék a szélsőséges spektrum-politizálás fő sodorba kerülését. Arra Löwenstein sem ad közelebbi meghatározást, hogy pontosan mikorra tehető az a pillanat, amikor a társadalmi-politikai folyamatok már visszafordíthatatlanok.

Löwenstein erre tehát nem is tesz kísérletet. Ellenben példákat hoz fel arra, hogy melyek lehetnek a figyelmeztető jelzések. Egyebek mellett ilyen az, ha az antidemokratikus erők meghatározó szerepet játszanak a jogalkotási folyamatokban - ilyen például, ha a szélsőséges politikai elem meghatározó szerepet játszik egy koalíciós kormányban, a jogalkotási döntésekhez szükséges demokratikus többségben a mérleg nyelvét játssza stb. Erre nézve Löwenstein megfogalmazta, hogy az antidemokratikus erőkkel szemben folytatott töretlen - és befolyásmentes - jogalkotási gyakorlat az egyetlen, amely képes megakadályozni a jogállamiságot veszélyeztető eszmék további térnyerését. Vagyis, ki kell zárni a politikai diskurzusból, amelynek legrugalmasabb eszköze az ilyen politikai erők teljes ignorálása a többi párt részéről. Összességében ezek alkotják a militáns demokrácia koncepcióját. ${ }^{249}$

A Legislative Control of Extremism in European Democracies tanulmányát Löwenstein a korábbi gyakorlatának megfelelően 1938-ban két részletben közölte le. Írásában részletesen elemzi azokat a jogalkotási eszközöket, amelyekkel érdemben képes a demokratikus állam megfosztani az antidemokratikus erőket a hatalom megszerzéséhez szükséges eszközeiktől. Löwenstein a demokrácia és az antidemokratikus erők közötti - ekkor még tisztán politikai küzdelmet valódi háborúként írja le. Ténylegesen harcként jelöli meg a hatalomért folytatott

\footnotetext{
${ }^{248}$ Karl, LoewensteIn: Autocracy versus Democracy in Contemporary Europe I. In: The American Political Science Review 1935/4., pp. 571-593.; Karl, LoEWEnSTEIN: Autocracy versus Democracy in Contemporary Europe II. In: The American Political Science Review 1935/5., pp. 755-784.

${ }^{249}$ LOEWENSTEIN 1937a, pp. 417-432.; LOEWENSTEIN 1937b, pp. 638-658.
} 
versenyt. Mindezek alapján arra a következtetésre jut, hogy - a háború analógiájával élve -, ha a háborúban a győzelem érdekében mindent fel lehet és kell használni, akkor ugyanez igaz kell, hogy legyen az antidemokratikus politikai erők elleni fellépés során. És Löwenstein szerint, végső soron az is mindegy, hogy ennek milyen ára van. ${ }^{250}$

Súlyos szavak ezek. A nácik 1933-as politikai hatalomátvételétől 1938-ig tartó időszak egyébként bő egy kormányzati ciklus lenne egy demokratikusan müködő államban. Ez alatt az idő alatt tömeges jogsértéseket követtek el és a jogállamiságot belülről, legitimációval saját képére formálta a náci párt, amely megállíthatatlannak bizonyult politikai és katonai értelemben véve egyaránt. Mindez mélyen elkeserítette Löwensteint és egyben meg is rémítette, amely nagy mértékben hozzájárult korábbi visszafogott téziseinek egyfajta radikalizálódásához.

\section{Végül The Balance of Legislative and Executive Power: A Study in Comparative Constitutional} Law címmel 1938-ban megjelent írásában újra előveszi korábbi állsápontját a militáns demokráciát illetően és kiterjeszti a korábban megfogalmazott értelmezési kereteket. Úgy látja az antidemokratikus veszély egész Európát bekebelezte és nem kímélte az olyan erős demokratikus identitással rendelkező államokat sem, mint Olaszország, Spanyolország és Németország. Sorra alakultak a náci pártok Franciaországban, a skandináv államokban és Közép-Európa államaiban. Löwenstein szerint csupán idő kérdése, hogy ezen államok is elveszítik demokratikus integritásukat, s ehhez nem is feltétlenül kell háborút indítani. Nem beszélve arról, hogy még az Egyesült Királyságban is nem kevés náci szimpatizáns volt a társadalom magasabb köreiböl. ${ }^{251}$ Az Egyesült Államokban pedig ekkor még igen messze jártak Jim Crow ${ }^{252}$ betiltásától. Löwenstein mindezek alapján, figyelemmel az angolszász társadalmakról szervezett benyomására, indokoltnak látja és ezért javaslatot tesz az Egyesült Államok politikai rendszerének védettebbé tételére. Szerinte az akkor Washingtont meghatározó izolációs politika nemhogy immunizálja - ahogyan sokan ezt az amerikai döntéshozók közül remélték - hanem éppen ellenkezőleg, sokkal jobban kiteszi a radikalizálódás veszélyének a nemzeti politikát, hiszen a politikai kiegyensúlyozottságot látens módon a nemzetközi kapcsolatok is garantálják.

\footnotetext{
${ }^{250}$ Karl, LoEwenstein: Legislative Control of Extremism in European Democracies. In: Columbia Law Review 1938/4., pp. 591-622.

${ }^{251}$ Lásd a British Union of Fascists mozgalmat.

${ }^{252}$ Az Egyesült Államokban a második világháborúig, de egyesek szerint még utána is az 1970-es évekig müködött egy nagyon erős rasszista elkülönítése és ellehetetlenítése a fekete lakosságnak. A Jim Crow - egy kitalált 19. századbeli megnevezése a feketéknek - megjelöléssel illetett szegregáció az egykor volt Amerikai Államok Konföderációja területén, az ún. déli államokban sokáig tartotta magát.
} 
Löwenstein ezért egy szisztémát javasol, amely jobban megfelel a kor kihívásainak. Álláspontja szerint egy fizikailag és szervezetileg is kisebb méretü jogalkotó könnyebben védekezhet és könnyebben védhető meg a szélsőséges politikai eszmék bejutásától. Madison és Mill elméletét alapul véve azzal az analógiával élhetünk, hogy a kis létszámú választott képviselők és tisztségviselők nagyobb eséllyel lesznek a családi neveltetésük vagy az iskolai képzettségük miatt felvértezve a szélsőséges gondolatokkal szemben. Továbbá, ha kevesebb szervezet vesz részt a döntéshozatalban, akkor a döntéshozatal folyamata gyorsabb lesz, ezáltal kevesebb idő marad a politikai kompromisszumok és háttéralkuk kijátszására, amelyek szintén kiskaput jelentettek a radikális eszméknek. Végül, ha kevesebb személy és kevesebb szervezet vesz részt a döntéshozatalban, akkor ezzel a személyes és a szervezeti-ágazati érdekek indokolatlan felülreprezentálását is elkerülheti az állam.

Ezzel párhuzamosan javaslatot tesz a végrehajtó hatalom jogköreinek jelentős mértékü bővítésére, amely így új jogkörökkel felvértezve még hatékonyabban képes védekezni, valamennyi demokratikus intézmény megóvása érdekében. ${ }^{253}$ Érdekes, hogy a háborús feszültség kiéleződésével fokozódik a Löwenstein javasolt intézkedések strukturális hatásfoka is: hiszen a néhány évvel korábban javasolt átmeneti szabályozás helyett immár állandó és mélyreható rendszerbeli változtatásokat indítványozott, amelyet nyugodtan tekinthetünk elmélete második lépcsőjének.

Löwenstein szerint az 1936-ban elfogadott Public Order Act ${ }^{254}$ (POA) egy indokolt, politikai racionalizmus által meghatározott és nem utolsó sorban arányos szabályozás, amelyet elfogadásakor nagymértékben támogatott. A törvény ma is hatályban van, annak ellenére, hogy az a társadalmi valóság, amelyben született, megközelítőleg sem hasonlítható össze a mai kor politikai környezetével. A második világháborút megelőző két évtizedben a fasizmus kifejezetten divatos politikai irányzatnak számított Európa szerte, még az Egyesült Királyságban is. ${ }^{255}$ Az Egyesült Királyságnak tehát POA elfogadásakor olyan veszélyt kellett mérlegelnie, amely számottevően nem jelent meg a kormányzás irányára is kiható politikai pártok között, ugyanakkor a klasszikus demokráciák sorra hajoltak meg az új típusú,

\footnotetext{
${ }^{253}$ Karl, LoEwENSTEIN: The Balance of Legislative and Executive Power: A Study in Comparative Constitutional Law. In: The University of Chicago Law Review 1938/4., pp. 566-608.

${ }^{254} \mathrm{http://www.legislation.gov.uk/id/ukpga/1936/6} \mathrm{(letöltés} \mathrm{dátuma:} \mathrm{2019.} \mathrm{09.} \mathrm{29.)}$

255 Iain Christopher Edward, CHANNING: Blackshirts and White Wigs: Reflections on Public Order Law and the Political Activism of the British Union of Fascists. University of Plymouth Research Theses, 2014. https://pearl.plymouth.ac.uk/bitstream/handle/10026.1/2897/2014channing10128808phd.pdf?sequence=1\&isAll owed=y (letöltés dátuma: 2019. 09. 29.)
} 
tömegpártok által meghatározott politizálás előtt. Ezek a pártok miután hatalomra kerültek, legalább autoriter rezsimeket alakítottak ki, s néhány esetben egypárt rendszer jött létre. Ez mindenképpen elrettentette a szélsőséges pártokhoz egyáltalán nem szokott brit közéletet. Nem volt tehát előzmények nélküli a náci német vezetők gunyoros megjegyzése: „Mindig ez marad a demokrácia egyik legjobb vicce: hogy maga bocsátja halálos ellenségei rendelkezésére azokat az eszközöket, amelyekkel megsemmisíthető." 256

${ }^{256}$ Karl Dietrich, BRACHER, Manfred, FUNKE, Hans-Adolf, JACOBSEN: Nationalsozialistische Diktatur 1933-1945. Eine Bilanz 


\subsection{A militáns demokrácia jelentésének pluralizálódása}

Löwenstein elképzelése mai szemmel nézve leegyszerüsítő volt, legalábbis abban az értelemben mindenképpen, hogy számos esetben nem lett volna alkalmazható a militáns demokrácia szankciórendszere, vagy alkalmazása indokolatlan és aránytalan lett volna. A hidegháborús évek alatt a nyugati típusú demokráciák ${ }^{257}$ mentesek voltak a látványos politikai szélsőségektől, azonban a felszín alatt lappangó belső politikai eróziós folyamatok nem lanyhultak. Az ezekre adott különféle válaszok tükrözik azt a történelmi, jogi és politikai környezetet, amelyben és amelyre születtek az adott koncepciók. Ezekben közös, hogy Carlo Schmid meghatározását nagyjából elfogadták kiindulópontként. Schmid szerint nem része a demokratikus koncepciónak, hogy a politikai rendszer megteremtse az általa szolgált demokratikus állam elpusztításának előfeltételeit. ${ }^{258}$

Magyarán nem csak, hogy nem elvárható a demokrácia számára önpusztító eljárások befogadása, de egyenesen az szolgálja a demokráciát, ha aktív intézkedések megtételére is lehetőséget biztosító eljárásokat emel be a jogalkotó a politikai eljárások közé. Pedahzur militáns demokráciája első sorban olyan államokban nyújthat stabilitást a politikai rendszer számára, ahol a demokrácia az erőszakos és szélsőséges szerveződések folyamatos támadása alatt áll, vagy a demokratikus politikai rendszer nem erős liberális alapokon jött létre. ${ }^{259}$ Példaként Pedahzur a Herrenvolkot, ${ }^{260}$ illetve az etnikai demokráciát ${ }^{261}$ hozza fel, amelyből azt a következtetést vonhatjuk le, hogy értelmezésében a legszélsőségesebb támadásokra a legszélsőségesebb és legmegfelelőbb válasz a militáns demokrácia.

Pedahzur a védekező demokráciát - összevetve a militáns demokráciával - a liberális hagyományokhoz közelebb állónak nyilvánítja, bár megjegyzi, hogy ezen demokráciák sokszor bizonytalan kimenetelü politikai húzásra szánják el magukat a veszéllyel szembeni védekezéssel összefüggő célnak alárendelten. A jogrendszerbe beépítve nyitva hagynak egy kis

\footnotetext{
${ }^{257}$ Mary Ann, Glendon, Michael Wallace, Gordon, Christopher, OsaKwe: Comparative Legal Traditions. Text, Materials and Cases. West Publishing Company, St. Paul, Minnesota 2006., p. 14.

${ }^{258}$ Carlo, SCHMID: A Bundestag 1948. szeptember 8-ai ülésén elhangzott felszólalása https://www.spd.de/partei/personen/carlo-schmid/ (letöltés dátuma: 2019. 09. 29.)

259 Ami, Pedahzur: Struggling Challenges of Right-Wing Extremism and Terrorism within Democratic Boundries: A comparative Analysis. In: Studies in Conflict and Terroism 2001/5. (a továbbiakban: PEDAHZUR), p. 13.

${ }^{260}$ Mindamellett Ilan PAPPÉ izraeli kortárs történész Izraelnek a hatnapos háborút követően a palesztin lakossággal szemben folytatott magatartására utalva Izrael politikai berendezkedését a Herrenvolk eszmeiségéhez hasonlítja. https://www.counterpunch.org/2011/04/01/why-israel-is-not-a-democracy/ (letöltés dátuma: 2019. 09. 29.)

${ }^{261}$ Az etnikai demokráciára példa a Dél-Afrikai Köztársaság az apartheid idején.
} 
kaput, amely lehetőséget ad arra, hogy a jogállamiságot alkalom adtán és szigorúan időlegesen átértékeljék. Tipikus eszközeik közé sorolható, hogy alkotmányos vagy törvényi szinten meghatározott anyagi jogi felhatalmazás birtokában eltilthatnak egyes pártokat a politikai versenyben való részvételtől. Abban az esetben, ha a felmerült veszélyekkel szemben elégtelennek bizonyulnak a parlament által gyakorolható eszközök, ezen demokráciák a büntető igazságszolgáltatás eszközeihez nyúlnak. Ezzel kapcsolatosan azonban nem szabad elfelejtenünk, hogy a terrorizmus megjelenése - egy stabil büntetőjogi struktúra ellenére is képes annyira elbizonytalanítani a jogalkalmazókat, hogy időnként vitatható a jogállamiság kereteinek megtartása a büntetőeljárás egyes szakaszai esetében. ${ }^{262}$

Apter szerint nem engedheti meg magának egyik állam sem, hogy a veszély elhárítása idején piaci alapon próbálja kezelni a helyzetet, mivel indokolt és elfogadható érv saját fennmaradásának érdekében tett minden eljárási és politikai lépés. ${ }^{263}$ Pedahzur szerint hosszútávon káros lehet a demokráciára és így veszélyt jelenthet, ha a jogállamiság tekintetében általánosan megfogalmazott rugalmasságot a büntetőjog esetében is alkalmazza a jogalkotó. Ezzel ugyanis veszélyezteti az állam a kiszámítható és törvényes eljárást és ítélkezést, amely egy valódi jogállam alapvető értéke. Mindebből Pedahzur arra a következtetésre jut, hogy a szolgáltató állam és a jövő-orientált állam elválasztásából a jövő-orientált állam koncepciója társítható a védekező állam koncepciójával. Ennek az oka az, hogy az jövő-orientált államot meghatározó politikai diskurzus adhat keretet az állampolgárok számára, hogy véleményt nyilváníthassanak a demokráciát alkotó értékekről. ${ }^{264}$ A védekező demokráciáról kialakult koncepciót Pedahzur egyértelműen a liberális demokrácia keretei között helyezi el. Az utilitarista gondolatokkal ugyanis az még összeegyeztethető, ha a többség jogainak érvényesülése érdekében a kisebbség jogait korlátozzák.

Érdekes megállapítása Pedahzurnak, hogy párhuzamot von a védekező demokrácia és a jóléti társadalom között. Ugyanis szerinte közös a kettőben az állam aktív szerepvállalása, különféle eszközökkel gyakorolt direkt hatása a társadalomra, amellyel a közjó érvényesülését

\footnotetext{
${ }^{262}$ Lásd különösen a nyilvános eljáráshoz vagy a védelemhez való jog érvényesülését, a fogvatartás jogalapját és körülményeit meghatározó szabályok módosításait, valamint a titkos információgyüjtő eszközök alkalmazását meghatározó szabályokban bekövetkezett lazítást. Szembe ötlő, hogy ezek a változások rendszerint egy-egy elkövetett terrortámadást követően keletkeznek. A témáról lásd bővebben Ronald D., Crelinsten, Alex P., ScHMID: Western Responses to Terrorism: A Twenty Five Year Balance Sheet. In: Terrorism and Political Violence 1992/4., pp. 332-333.

${ }^{263}$ APTER, David: The Poiltics of Modernization. University of Chicago Press, Chicago, 1965. idézte: PedAHzur, p. 14.

${ }^{264}$ Pedahzur, p. 13.
} 
célozzák. ${ }^{265}$ Ennek egyik legkézenfekvőbb és leghatékonyabb eszköze az oktatás. Habár hatását csak hosszútávon fejti ki. Általában elmondható, hogy az extrémizmus megjelenéséhez köthető politikai krízisekre adott leghatékonyabb válasz a megelőzés, amelyet a köz- és felsőoktatásban megjelenő kötelezően teljesítendő politikai tematikájú tantárgyak bevezetése jelenthet. A szélsőséges politikai megoldásokat elutasító nyugati demokráciákban így vált a második világháborút követő évtizedekben általánosan a felsőfokú tanulmányok természetesen részévé, amelyet a szélsőséges politikai eszmék elleni küzdelem hatásos eszközeként jelölt meg az ENSZ. ${ }^{266}$

Három kiegészítő korlátot határoz meg Pedahzur: ${ }^{267}$ 1) az improvizált vagy adminisztratív korlátot, 2) a jogi és bírói korlátot, valamint 3) a szociális korlátot. Mindhárom korláttípust igen hatásos demokrácia védő eszköznek tartja Pedahzur, miközben látszik, hogy hatékonyságuk nagyban múlik a döntéshozók személyes helytállásán és az érintett intézmények vagy személyek koordinációján. Az improvizált korlátot lehetne ad hocnak is nevezni, hiszen ebben az esetben a létező szabályok keretén belül kvázi-szabályalkotás jelleggel hoz igazgatási vagy más döntést az arra felhatalmazott szerv. A döntések minden esetben politikai jellegüek. Függetlenül attól, hogy azt a helyi rendőrfönök hozza, ${ }^{268}$ a parlament házelnöke, vagy a közmédia vezetése. ${ }^{269} \mathrm{~A}$ jogi és bírói korlátot tágan, illetve szűken is lehet értelmezni. A tág értelemben vett korlát azt jelenti, hogy a demokráciára veszélyt jelentő politikai jelenségre adott válasz több, mint amelyre a jog, illetve jellemzően a büntetőjog vagy a közigazgatási jog képes lenne. Erre hozza példaként Pedahzur a japán parlament válaszát az Aum Shinrikyo szerveztere, amely felelös volt a tokiói metróban történt ideggáz támadásért. A japán parlament döntése nyomán a súlyos támadás elkövetésében érintett szervezeteket - és tagjaikat - a jövőben a kijelölt kormányszervek előzetes bejelentés nélkül vizsgálhatják, tevékenységükről három havonta számot kell adniuk és tulajdonszerzésüket korlátozhatják vagy kizárhatják. És ezen az sem változtat, hogy időközben a szervezet jogutód nélkül megszünt és más néven ${ }^{270}$ alakult meg újra. Egy másik példaként Pedahzur a német Republikaner párt ellen folytatott intenzív

\footnotetext{
265 uo.

266 Preventing violent extremismthrough education. A guide for policy-makers. UNESCO 2017 http://unesdoc.unesco.org/images/0024/002477/247764e.pdf (utoljára letöltve: 2019. 09. 29.)

${ }^{267}$ PEDAHZUR, pp. 7-12.

268 Raphael, Cohen-Almagor: Combating Right-Wing Political Extremism in Israel: Critical Appraisal. In: Terrorism and Political Violence 1997/4., p. 84. 5. lj.

269 Raphael, COHEN-Almagor: The Boundaries of Liberty and Tolerance The Struggle against Kahanism in Israel. Gainesville: University Press of Florida 1994. (a továbbiakban: CoHEN-ALMAGOR 1994), pp. 219-229.

${ }^{270}$ Az Aum Shinrikyo korábbi tagjai 1999-ben megalapították az Aleph nevü szervezetet, amelynek ma közel 2000 tagja van.
} 
nemzetbiztonsági megfigyelést és rendőrségi ellenőrzést hozza fel, amelyhez érdekes módon nem társult a párt betiltása. Németországban ugyanis az alkotmányellenes célra létrejött pártokat automatikusan betiltják. A Republikaner párt esetében az alkotmányellenességet ugyan kimondták, de a betiltás elmaradt. ${ }^{271}$

Pedahzur három lényeges szempont szerint értékeli egy politikailag tudatos társadalom jelentőségét: 1. jól szervezett érdekcsoportok, amelyek a jogalkotó és a média megszólításával érhetnek célt a szélsőséges mozgalmakkal szemben, 2. civil kezdeményezések sok esetben vonzóbbak lehetnek azoknak, akik politikailag nem elkötelezettek és szívesen állnak egy-egy ügy mögé, és végül 3. az alulról jövő kezdeményezések többnyire egy-egy konkrét személy érdekérvényesítő szándékából gyökereznek, és nem is feltétlenül céloznak társadalmi változást hosszú távon. ${ }^{272}$ Ugyanakkor a társadalmi mobilizáció legitimációs keretei között a gyenge immunitású politikai rendszerekben könnyen vissza is lehet élni. Erre mutat rá Löwenstein a militáns demokrácia eredeti koncepciójában.

Walker 2011-ben levezette intelligens militáns demokrácia koncepcióját, ${ }^{273}$ amelyben értékeli és minősíti a nyugati államok erőfeszítéseit, amelyeket a moralitás, a politika, a szociológia és a jog területén tettek a demokráciára veszélyes szélsőséges eszmék leküzdésére. Walker megállapítja, hogy az állam számára kettős cél érvényesül párhuzamosan: (1) önnön fennmaradása, illetve (2) értékeinek győzelme. ${ }^{274}$ Utóbbi mindenképpen vegyíti a politikai és morális elemeket a jogi absztrahációval. Az értékek meghatározása több szinten és formában ölthet testet, amelyek között a legfontosabb elválasztás az alapvetően normatív erővel bírók és az alapvetően politikai tartalmúak. A normatív erővel bírók közül a legalapvetőbb és politikai kinyilatkoztatásra is alkalmas eszköz az alkotmány, bár preambulumának normatív ereje erősen vitatott. ${ }^{275}$ Walker azt javasolja, hogy a demokrácia értékei mentén, azok korlátozás nélküli és folyamatos érvényesülése mellett dolgozzon ki a jogalkotó olyan toleráns szabályrendszert,

271 G., MORE: Undercover Surveillance of the Republikaner Party: Protecting a militant Democracy or Discrediting a Political Rival. In: German Politics 1994/2., pp. 284-292.

272 PEDAHZUR, p. 12.

${ }^{273}$ Clive, WALKER: Militant Speech About Terrorism in a Smart Militant Democracy. In: Mississippi Law Journal 2011/4. (a továbbiakban: WALKER 2011a), pp. 1396-1453.

${ }^{274}$ Clive, WALKER: Terrorism and the Law. Oxford University Press, Oxford 2011. (a továbbiakban: WALKER 2011 b), pp. 35-106.

275 SONNEVEnd Pál, JAKAB András, Csink Lóránt: The Constitution as an Instrument of Everyday Party Politics: The Basic Law of Hungary. In: Constitutional Crisis in the European Constitutional Area. Theory, Law and Politics in Hungary and Romania. (ed. Armin, von Bogdandy, Pál, SonNEvend,) C.H.Beck-Hart-Nomos 2015., pp. 49-50.; Liav, ORGAD: The Preamble in Constitutional Interpretation. In: International Journal of Constitutional Law 2010/4., pp. 714-738. 
amely megfelelően idomul a kihívást jelentő veszély és a demokratikus értékek - akár csak átmeneti - felfüggesztésének elkerülésével felmerülő ellentmondás leküzdésére.

Walker szerint az Egyesült Királyság nem a legintelligensebb intelligens militáns demokrácia. ${ }^{276}$ Egyrészt, mert 1971-ben néhány ír terroristával szemben olyan intézkedéseket foganatosítottak, amelyek súrolják a kínzás határait, ${ }^{277}$ és mert több mint 30 évvel ${ }^{278}$ később sem „tanultak” a hibáikból (ld. az iraki megszállás alatt elkövetett szándékos bántalmazások és jogellenes emberölések). ${ }^{279}$ Ugyanakkor a brit anti-terror törvények mégis csak rendes ${ }^{280}$ törvények, vagyis a rendes jogalkotási eljárással alkotta őket a brit parlament, a többi törvénnyel egyenrangúan váltak a brit jogrendszer részévé és ennek megfelelő permanens jellegűek. A jogalkotó nem átmeneti szabályozásként szánta a vonatkozó törvényeket, bár tény, hogy számuk és megalkotásuk időbeli közelsége nem egy megfontolt és teljeskörü szabályozásra törekvő jogalkotói magatartásra utal. ${ }^{281}$ Az ún. Diplock ${ }^{282}$ bíróságok kisebb megszakításokkal,

\footnotetext{
276 WALKER 2011a, p. 1397.

277 Írország v. Egyesült Királyság, 5310/71. számú döntés https://www.law.umich.edu/facultyhome/drwcasebook/Documents/Documents/Republic\%20of\%20Ireland\%20v
} \%20United\%20Kingdom.pdf (letöltés dátuma: 2019. 09. 29.)

278 További ismert és vitaható vagy egyértelmúen jogellenes cselekmények a brit kormány részéről: Véres Vasárnap (1972), http://www.gov.uk/government/publications/report-of-the-bloody-sunday-inquriy (letöltés dátuma: 2019. 09. 29.);

az „Operation Flavius” elnevezésú terrorellenes katonai akció 1988-ban, amelyet a brit királyi hadsereg SAS nevü különleges müveleti feladatokra létrehozott alakulata hajtott végre http://www.uio.no/studier/emner/jus/jus/JUR5710/h10/undervisningsmateriale/13okt_In\%20the \%20case \%20of \%20McCann\%20and\%20Others\%20v.pdf (letöltés dátuma: 2019. 09. 29.); és Jean de Menezes 2005-ös halála, amely esetében a sajtó - átvéve a Metropolitan Police hivatalos magyarázatát - az áldozat részbeni felelősségét is megállapította

https://www.independent.co.uk/news/uk/crime/seven-mistakes-that-cost-de-menezes-his-life-1064466.html (letöltés dátuma: 2019. 09. 29.).

${ }^{279}$ Ministry of Defence, United Kingdom: The Aitken Report: an investigation into cases of deliberate abuse and unlawful killing in Iraq in 2003 and 2004. Westminster, London, 2008.; House of Lords, House of Commons Joint Committee on Human Rights: UN Convention Against Torture: Discrepancies in Evidence Given to the Committee About the Use of Prohibited Interrogation Techniques in Iraq. Twnety-eighth Report of Session 2007-08. Westminster, London, 2008.; Lásd továbbá Baha Mousa Public Inquiry report, 2011 https://assets.publishing.service.gov.uk/government/uploads/system/uploads/attachment data/file/279190/1452 i .pdf (letöltés dátuma: 2019. 09. 29.)

${ }^{280}$ Az Egyesült Királyságban a szuverenitás letéteményese a Parliament, így jogrendszerében nincs hierarchia a parlament normatív aktusai között, illetve ennek megfelelöen - a törvények felett álló, elkülönült - alkotmányról sem beszélhetünk.

${ }^{281}$ A 2000-es Terrorism Act, a 2001-es Anti-terrorism, Crime and Security Act, a 2003-as Criminal Justice Act, a 2001-es Anti-terrorism, Crime and Security Act 21-23. §-ainak végrehajtásáról szóló 2004-es rendelet, amelyet speciális jellege miatt a brit parlament is megerösített http://www.legislation.gov.uk/uksi/2004/751/pdfs/uksi 20040751 en.pdf(letöltés dátuma: 2019. 09. 29.), a 2005ös Prevention of Terrorism Act, a 2006-os Terrorism Act, az ENSZ Biztonsági Tanácsának rendelete alapján kiadott 2006-os Terrorism rendelet, amelynek az Egyesült Királyság Legfelsőbb Bírósága 2010-ben megállapította ultra vires jellegét és hatályon kívül helyezett, a 2008-as Counter-Terrorism Act, a 2009-es Coroners and Justice Act, a 2013-as Justice and Security Act, végül a 2015-ös Counter-Terrorism and Security Act.

${ }^{282}$ Kenneth Diplock, Baron Diplock, ír származású brit jogász, aki Law Lordként javaslatot tett 1972-ben az esküdtszék nélküli egyesbíróságok felállítására az északír terrorizmus leküzdésére. 
de 1973 óta müködnek az Egyesült Királyságban, ${ }^{283}$ azonban létrehozatalakor közel állt az Egyesült Királyság a polgárháborúhoz. Lényege, hogy törvényben meghatározott büncselekmények esetében, amelyeknél egyébként alapesetben van esküdtszék, kivételesen mellőzik az esküdtszék alkalmazását. Továbbá más eljárásokhoz képest, ahol az esküdtszék hiányát tanáccsal pótolják, ebben az eljárásban kizárólag egyesbíró jár el.

A Diplock bíróságokat eredetileg az Észak-Írországban elkövetett terrorcselekmények vagy azzal összefüggésben az Egyesült Királyságban máshol elkövetett terrorcselekmények elbírálására hozták létre. ${ }^{284}$ Walker szerint hiába a területi és tárgyi hatály, az esküdtszék nélküli egyesbírók müködése az Egyesült Királyságban kivételessége ellenére idővel alapeljárássá vált a terrorizmushoz kapcsolódó büntetőeljárásokban. ${ }^{285}$ Más oldalról megközelítve ugyanakkor szembetűnő, hogy az eljárást továbbra sem általánosan alkalmazzák valamennyi terrorizmussal gyanúsítható személy esetében. ${ }^{286}$ Azokból az esetekből és történelmi korszakokból, amikor mégis alkalmazták arra lehet következtetni, hogy csak akkor tartották fontosnak az általánostól való eltérést, ha azt az elkövetők száma és az eljárások dömping szerü mennyisége indokolttá teszi. Hiszen ebben az esetben a jogrendszer és az igazságszolgáltatás nem képes megfelelni a társadalom sürgető elvárásainak. Ilyen formán viszont csak annyiban állja meg a helyét Walker megállapítása a kivételes eljárás általánossá válásáról, ha a terrorcselekmények és a közvélemény éppen aktuális alakulását is figyelembe vesszük. Így viszont már ez a megoldás is kissé eshetőlegesnek tünik. Az Egyesült Királyság intelligens militáns demokrácia jellegét azonban - csak erre alapítva - elhamarkodott lenne elvitatni.

Mindezek alapján Walker szerint az intelligens militáns demokrácia három célnak kell, hogy egyszerre megfeleljen. Elsődlegesen, az intelligens militáns demokrácia hosszú távon gondolkodik. Erre a kivételes vagy különleges - nevezzük bárhogyan is - szabályozás átmeneti jellege miatt alkalmatlan. Vagyis a jogalkotónak a rendes jogalkotási eljárás keretei között kell megalkotnia egy olyan szabályt, amely minden tekintetben megfelel a demokratikus elvárásoknak: (1) alkotmányos szinten meghatározott általános követelmények érvényesülése (közérthető, megismerhető, illeszkedik a jogrendszerbe), (2) nem kivett a rendes normakontroll

\footnotetext{
283 a 2007. évi Justice and Security (Northern Ireland) Act https://www.legislation.gov.uk/ukpga/2007/6/pdfs/ukpga 20070006 en.pdf (letöltés dátuma: 2019. 09. 29.)

${ }^{284}$ Secretary of State for Nothern Ireland, Report of the Commission to Consider Legal Procedures to Deal with Terrorist Activites in Northern Ireland, 1972, Cm. 5185 http://cain.ulst.ac.uk/hmso/diplock.htm (letöltés dátuma: 2019. 09. 29.)

285 WALKER 2011 a, p. 1399.

286 A. és mások v. Egyesült Királyság, 2002. február 19-énkihirdetett 3455/05. számú döntés.
} 
eljárások alól, (3) megalkotásával azonos jogalkotási eljárás keretében megváltoztatható, és (4) hatályon kívül helyezhető.

A nemzetközi terrorizmus elleni küzdelemben a hatalmi ágak közül a végrehajtó hatalom szinte észrevétlenül kerül túlsúlyba a többi hatalmi ággal szemben, amelyet a rendeleti kormányzás széles körü elterjedésével is érzékelhetünk. A terrorellenes intézkedésekkel összefüggésben általános, szinte elfogadott jelenség a magánszféra és a magánszféra védelmének átértelmezése. Ezért - másodlagosan - kiemelten fontos, hogy az alapjogok hatékony védelme érdekében az intelligens militáns demokrácia egyre hangsúlyosabb módon tegyen lépéseket az alapjogvédelem terén. ${ }^{287}$ Harmadlagosan, az intelligens militáns demokrácia önmérsékletet gyakorol nem csak akkor, amikor úgymond nyugodt körülmények között van lehetőség megfontolt jogalkotásra, hanem akkor is, amikor a jogalkotást politikai turbolencia határozza meg. Jelesül egy terrorcselekmény elkövetését közvetlenül követő történelmi időszakban. Ellenkező esetben olyan túlkapások születhetnek, mint a 2002-es amerikai USA PATRIOT Act, ${ }^{288}$ amely elfogadásakor ellentétes volt az amerikai alkotmánnyal. ${ }^{289}$

Az intelligens militáns demokrácia sajátja, hogy nem csupán a terrorizmus pusztítását célozza, hanem a hatására kialakuló káros társadalmi-politikai folyamatokat is megpróbálja kezelni. A terrorellenes stratégiák ${ }^{290}$ közismert négy eszköze: (1) üldözés, amelynek keretében megakadályozzák a terrorcselekményeket, (2) megelőzés: amelynek keretében megelőzik, hogy valaki terroristává váljon, vagy erőszakos szélsőségeket támogasson, (3) védekezés: a terrorcselekmények elleni védekezés megerősítését célozza, és végül (4) felkészülés: ha egy terrortámadást nem lehet megelőzni, a káros hatásait kell minimalizálni. A klasszikus büntetőjogi megközelítés keretei között elsődlegesen az üldözés eszközét alkalmazzák, ugyanakkor a 2005-ös londoni terrortámadás megmutatta, hogy a terrorizmus nem valamilyen távoli ország honosaihoz köthető csupán, hanem ugyanúgy elkövethetik radikalizálódott saját

\footnotetext{
${ }^{287}$ Clive, WALKER: The Threat of Terrorism and the Fate of Control Orders, Public Law 2010., pp. 4-17.; David, ANDERSON: Control Orders in 2011. Final Report of the Independent Reviewer ont he Prevention of Terrorism Act 2005. The Stationery Office 2012. https://terrorismlegislationreviewer.independent.gov.uk/wpcontent/uploads/2013/04/control-orders-2011.pdf (letöltés dátuma: 2019. 09. 29.)

${ }^{288} \mathrm{https://www.gpo.gov/fdsys/pkg/BILLS-107hr3162enr/pdf/BILLS-107hr3162enr.pdf} \mathrm{(letöltés} \mathrm{dátuma:} 2019$. 09. 29.)

${ }^{289} \mathrm{http} / /$ i.a.cnn.net/cnn/2007/images/09/26/mayfield.patriotact.summary.judgment.pdf (letöltés dátuma: 2019 . 09. 29.)

${ }^{290}$ Lásd az Európai Unió terrorizmus elleni stratégiáját, https://www.consilium.europa.eu/hu/policies/fightagainst-terrorism/eu-strategy/ (letöltés dátuma: 2019. 11. 19.)
} 
állampolgárai is. ${ }^{291}$ Ezért célszerü nagyobb hangsúlyt fektetni a megelőzésre, illetve bizonyítékok mindenáron való beszerzése helyett a hatékony megelőzéshez szükséges információ megszerzésére. ${ }^{292}$ Ez egyébiránt előrevetíti azt is, hogy a terrorizmus legyőzésében az intelligens militáns demokrácia hatékonyabb eszköznek tekinti az igazgatási jellegü lépéseket a büntetőjogi fellépésnél.

Otto Pfersmann szerint a militáns demokrácia egy politikai és jogi szerkezet, amelynek célja a demokrácia megőrzése azokkal a szándékokkal szemben, amelyek belülről próbálják megdönteni, vagy amelyek kívülről, de a demokratikus intézmények felhasználásával és némi társadalmi támogatással próbálják nyíltan lerombolni. ${ }^{293}$ Ezzel szemben Gregory H. Fox és Georg Nolte leszükíti a militáns demokrácia fogalmát egy sor olyan szabályra, amelyek célja és értelme annak kizárása, hogy demokratikusan megválasztott anti-demokratikus pártok felhatalmazással - megváltoztassák az állam demokratikus karaktereit. ${ }^{294}$ (Fox és Nolte elméletét részletesebben kifejtve és gyakorlati példákkal alátámasztva a következő alcím alatt tárgyalja az dolgozat.) Vannak, akik az illiberális demokrácia kialakulásának meggátolását tekintik a militáns demokrácia primer feladatának. ${ }^{295}$

Összességében elmondható, hogy a militáns demokrácia legfontosabb jellemzője, hogy inkább megelőző jelleggel lép fel és kevésbé reaktív (szankcionáló). Persze ehhez az is hozzátartozik, hogy a demokratikus többséggel megválasztott politikai tömörülés demokrácia romboló intézkedéseit sokkal nehezebb kivédeni, mint eleve meggátolni a hatalomgyakorlás lehetőségét. Ebből következik az is, hogy a demokrácia többségi elvét is felül kell, hogy írják bizonyos szabályok. Ezek a szabályok jellemzően a demokráciát strukturálisan meghatározó alkotmányos rendelkezések - hiszen ezeket a legkönnyebb megvédeni a különleges alkotmányozási rendelkezések ${ }^{296}$ alkalmazásával. Fontos szempont továbbá, hogy a

\footnotetext{
${ }^{291}$ Clive, WALKER: Know Thine Enemy as Thyself: Discerning Friend from Foe under Anti-Terrorism Laws. In: Melbourne University Law Review 2008/3., pp. 275-301.

${ }^{292}$ Clive, WALKER: Intelligence and Anti-Terrorism Legislation in the United Kingdom. In: Criminal Law \& Society Change 2005/4-5., pp. 387-422.

${ }^{293}$ Otto, Pfersmann: Shaping Militant Democracy: Legal Limits to Democratic Stability. In: SAJó, András (ed.) Militant Democracy. Eleven International Publishing, Amsterdam 2004., p. 47.

${ }^{294}$ Gregory H., FoX, Georg, NOLTE: Intolerant Democracies. In: Harvard International Law Journal 1995/1., p. 6.

${ }_{295}^{295}$ Samuel, ISSACHAROFF: Fragile Democracies. In: Harvard Law Review 2007/6., p. 1409.

${ }^{296}$ A teljesség igénye nélkül: minősített vagy külön alkotmányozó többségi szavazati arány meghatározása, több ciklusos szavazás elrendelése, az általános törvényhozótól eltérỏ alkotmányozó szerv meghatározása, több fórum bevonása, megváltoztathatatlan alkotmány-mag kijelölése (karantén), kötelező népszavazás vagy előzetes alkotmánybírósági normakontroll alkalmazása stb.
} 
demokratikusság tartalmi (érdemi) értelmezése, vagyis védelme több fórumnál legyen telepítve, amelyek közül nem mindegyik kell, hogy pártpolitikai érdekek által legyen meghatározva. Érdekes megfigyelni, hogy a militáns demokrácia szinte minden esetben egyegy konkrét célpont ellen lép fel, vagyis nem általános szabályokról van szó, hanem a hatósági ügyek egyediségéhez hasonlóan ebben az esetben is eseti mérlegeléssel lehet csak megállapítani a politikai szándék antidemokratikus jellegét. Ráadásul sok esetben keverednek a fogalmak: nemzetbiztonság, közrend, közbiztonság.

A militáns demokráciát megalapozó szabályok az államok többségének esetében észrevétlenül - vagy negatív történelmi előzményeket követően direkt módon ${ }^{297}$ - az alkotmányok részévé váltak, ezért önmagában értelmetlen az a vizsgálat, hogy egy állam rendelkezik-e önvédelmi eszközökkel vagy nem. Boventer összehasonlította az Egyesült Államok, Franciaország, valamint Németország által alkalmazott, a demokratikus rendet védő megoldásokat. Elemzését azzal a megállapítással zárja, hogy a demokratikus önvédelem első sorban annak függvénye, hogy az állampolgár képes-e a fellépésre és rendelkezik-e a politikai elkötelezettséggel. Boventer szerint ez a liberális (freihetlich) etosz az, amely leginkább alkalmas arra, hogy a totalitárius rendszerek kialakulása ellen védekezzen. ${ }^{298}$

Sajó szerint a militáns demokrácia tárgyalásának primer kérdése, hogy eltérhet-e jogállami eszközeitől egy állam, korlátozhatók-e az alapjogok megelőző jelleggel, anélkül, hogy egyébként az alkotmányosság sérülne. ${ }^{299}$ Ebben az esetben ugyanis, nem egy konkrét jogsértésről vagy arra irányuló - előkészülethez, főleg nem feltétlenül kísérlethez hasonlítható bizonyossággal megvalósuló - cselekményről van szó, hanem egy lehetőségről, amely a jogszerüség kereteit nem lép át. Ráadásul a politika világába tartozik, vagyis megítélése során sem mellőzhető a politika. A politika viszont alapvetően nélkülözi a jogrendszer strukturális tisztaságát. Sajó szerint az alkotmányos jogállam preventív védelmének fontosságát a kockázat adja, viszont a kívánt hatás eléréséhez - éppen a politikai jelleg miatt - elég lehet az is, ha a lehetőség adott az alkalmazására. ${ }^{300}$

\footnotetext{
${ }^{297}$ Pl. Németország a második világháborút követően.

${ }^{298}$ Egyebek mellett ilyen volt pl. a két világháború között Finnország fellépése a finn kommunisták ellen, illetve a csehszlovák kormány fellépése a szudéta-német vidéken kibontakozó szélsőjobboldali pártalakítási kezdeményezések elfojtására. Lásd bővebben Giovanni, CAPOCCIA: Defending Democracy: Reactions to Extremism in Interwar Europe. European Journal of Political Research 2001/4., pp. 431-460.

${ }^{299}$ SAJÓ András: Önvédő jogállam. In: Fundamentum 2002/3-4. (a továbbiakban: SAJó), p. 55. ${ }^{300}$ Uo.
} 
A kockázat meghatározását illetően ugyanakkor Sajó nagyvonalúan a magyar politikatörténetre utal vissza. Ez annyiban helytálló, hogy a politikai kockázatot valóban csak az adott ország politikatörténete, alkotmányos hagyományai alapján lehet érdemben értékelni. Minthogy a társadalmi valóság által meghatározott nemzeti szempontok nem helyettesíthetők be egy általánosító és így leegyszerüsítő, sematikus nemzetközi szempontrendszerrel, anélkül, hogy elveszítenénk azt a nüánszot, amely lehetővé teszi a militáns demokrácia eszközeinek precíziós alkalmazását. Ugyanakkor éppen a magyar politikatörténet elmúlt 150 évének rendkívül éles váltásai nehezítik a magyar politikára alkalmazható kockázat értékelését és meghatározását. Hiszen - folyamatos és szerves társadalmi-politikai fejlődés hiányában - a védett és meghatározó értékek kiválasztása diszkrecionális döntés eredménye lesz. Vagy - analógiát alkalmazva - külföldre tekinthetünk iránymutatásért, amely már a fentebb tisztázott szempontok alapján hibás lépés lenne.

Sajó szerint az autoriter rezsimeket az emocionalizmus tartja össze. Hozzáteszi továbbá, hogy az érzelmi-mozgalmi politizálásnak az egyetlen valóságos célja a kizárólagos hatalom mindenáron való megszerzése és megtartása. ${ }^{301}$ Ugyanakkor a politikában a hatalommegszerzése érdekében folytatott politikai (kampány) tevékenységet túlzó a politika szándékát is meghatározónak tekinteni. Az altruisztikus, az utilitarista vagy kizárólag egy zárt elit érdekében cselekvő kormányzás önmagában nem egyenes következménye korábban lezajlott politikai versenynek. A politikai megnyilvánulások többnyire nem önmagukért való cselekvések, hanem viszonylagosak és alapvetően eszközjellegük a meghatározó. Vitatható módon Sajó szerint védendő érték a parlamentárisan kialakult politikai status quo. ${ }^{302} \mathrm{Ez}$ azonban csak annyiban helytálló, amennyiben a status quo-t az adott parlamenti ciklusra alkalmazzuk, hiszen szabad választások egyik ismérve, hogy a választás alkalmával a választójoggal rendelkező állampolgár véleményt nyilvánít. Bár azt Sajó is elismeri, hogy a megvédendő alkotmányos rend nem semleges. ${ }^{303}$

\footnotetext{
301 SAJÓ, p. 56.

302 SAJÓ, p. 58.

303 Uo.
} 


\subsection{A militáns demokrácia 20. századi alkalmazásának gyakorlata}

A német nemzetiszocialista párt térnyerése egyértelművé tette a 2. világháborút megelőzően, hogy szükséges valamilyen keretrendszer megalkotása, amely alkalmas és képes meggátolni a plurális demokrácia belső átalakítását. Ebből kifolyólag a militáns demokrácia elsődlegesen a politikai pártok lehetőségeit vette górcső alá a 20. század második felében is. Meir Kahane amerikai ortodox rabbi 1971-ben alapította Izraelben a Kach nevü pártot, amellyel 1984-ben be is jutott a Knesszetbe. Egy vitatható parlamenti ciklust követően azonban 1988-ban eltiltották a parlamenti választásokon való indulástól. Meirt 1990-ben meggyilkolták, ekkor pártja két utódpártra szakadt, azonban 1994-ben a másik jogutódot is véglegesen eltiltották a választásokon való indulástól.

Nehéz helyzetbe került az állam, amikor 1984-ben Kahane rasszista és erőszakos pártja bekerült a Knesszetbe. Adekvát szabályozás híján, eseti szabályalkotással és kisegítő jogértelmezéssel próbálta orvosolni a helyzetet az állam. Kahane képviselői mentelmi jogát korlátozták és lényegében ellehetetlenítették, hogy törvényjavaslatot nyújtson be. Megtiltották továbbá, hogy használja a Knesszet postai szolgáltatásait. A parlamenti képviselők és az állami média egyszerüen nem vett róla tudomást, felszólalásairól kivonultak a képviselők, a parlamenti közvetítést pedig átmenetileg megszakították. ${ }^{304}$ Látható, hogy az eseti jogértelmezéssel is elérhetők apróbb sikerek, azonban a végleges eltiltáshoz bírói határozat kellett. A bíróság döntéséhez viszont egyértelmü, nyílt és alkotmányos szempontból is helytálló szabályozás kell.

A politikai rendszer mellett a társadalmi rendet veszélyeztető egyéb veszélyforrásokra is kiterjedhet a militáns demokrácia hatálya, ez pedig már messze túl mutat a Löwenstein által megfogalmazottakon. Sőt, ez már esetenként túl mutat a jogállamisághoz kapcsolódó alapelvekhez való jóhiszemű ragaszkodáson. Oroszországban az 1990-es demokratikus nyitás eredményeként lehetővé vált a szabad vallásgyakorlás és az egyházak újra szabadon müködhettek. Ez távolról vizsgálva megfelel a szabad vallásgyakorlás és az állam és az egyház szétválasztását kimondó elvnek, az Orosz Ortodox Egyház mégis elégedetlen volt. Ök ugyanis veszélyt láttak a teljes liberalizációban, mivel így a piac kinyitásával nem látták biztosítottnak az ortodox egyház monopol státuszát, s ezzel az orosz társadalom szerkezetét. ${ }^{305}$

\footnotetext{
${ }^{304}$ COHEN-AlmagOR 1994, pp. 219-229.

${ }^{305}$ Robert C., BLITT: How to Entrench a de facto State Church in Russia: A Guide in Progress. In: Brigham Young University Law Review 2008/3., p. 720.
} 
Az ortodox egyház által szorgalmazott módosítást végül 1997-ben alkotta meg a parlament, amely számos diszkriminatív rendelkezése mellett látványosan megvonja a tulajdonszerzés jogát a 15 évnél nem régebb óta tevékenységet kifejtő egyházi jogi személyek körében. Ez azt jelenti, hogy csak azok a régebbi hagyományos egyházak müködhettek teljes jogkörrel, amelyek már a Szovjetunió fennállása alatt is léteztek az országban. ${ }^{306}$ Ezzel nem csak a társadalomra, valamint az emberek testi és lelki épségére jelentenek veszélyt a külföldi egyházak, hanem nemzetbiztonsági kockázatot is jelentenek. Mindezt pedig az Orosz Tudományos Akadémia is támogatja. ${ }^{307}$

Törökország militáns szekuláris állam. ${ }^{308}$ A szekularizáció érdekében tett militáns lépések az Emberi Jogok Európai Bírósága szerint ${ }^{309}$ elfogadhatók, bár nem osztotta minden bíró a többségi álláspontot és a tudományos közösség sem feltétlenül osztja a meghatározó politikai véleményeket. ${ }^{310} \mathrm{~A}$ bíróság török tagja viszont a többségi állásponttal értett egyet, nem meglepő módon. Hiszen Törökország három korábbi alkotmánya egytől-egyig tartalmazott olyan politikai eszközöket, amelyeket a militáns demokráciával összefüggésben szoktak elkönyvelni. Az 1961-es alkotmánya alapján 6 párt, míg a jóval szigorúbb 1982-es alkotmánya ${ }^{311}$ alapján összesen 18 párt müködését tiltották be. ${ }^{312} \mathrm{Az}$ indok szinte minden esetben Törökország két alkotmányos alapelvére vezethető vissza: az ország területi integritásának sérthetetlenségére, ${ }^{313}$ valamint az állam teljes körben érvényesülő szekuláris jellegére. ${ }^{314}$ Más esetben Törökország a számottevő társadalmi támogatással rendelkező pártok esetében is alkalmazta militáns alkotmányos rendelkezéseit.

A török Refah Partisi (Jólét Párt) 1983-ban alakult, 1995-ben a szavazatok 22\%-át szerezte meg, s ezzel a parlamenti mandátumok több, mint 1/3-át. Előbb 1996-ban koalíciós

\footnotetext{
306 Svetlana, TyUlKINA: Militant Democracy. Central European University, 2011. http://www.etd.ceu.hu/2012/tyulkina svetlana.pdf (letöltés dátuma: 2019. 09. 29.) (a továbbiakban: TYULKINA), pp. 186-187.

307 TYULKINA, p. 188.

308 Patrick, MACKLEM: Guarding the Perimeter: Militant Democracy and Religious Freedom in Europe. Constellations, 2010/4., pp. 575-590.

${ }^{309}$ Az Európai Emberi Jogi Bíróság 44774/98. számú Leyla Şahin v. Törökország ügye.

${ }^{310}$ Bővebben lásd Antje, PEDAIN: Do headscarfs bite? In: Cambridge Law Journal 2004/3., pp. 527-580.

${ }^{311}$ Nem meglepö, hiszen eleve egy katonai puccs eredményeképpen született.

312 TYULKINA, p. 208.

313 Jellemzően a kurdok érdekeit védő pártok esetében.

314 Törökország 1920 óta hagyományosan tilt minden iszlamista irányzatot, az iszlámizmusnak teret engedő gondolatiságot az állami, a politikai és a társadalmi szervezetek részéről.
} 
kormánypárttá vált, majd 1998-ban a török Alkotmánybíróság a párt alkotmányellenes müködésére hivatkozva feloszlatta. A Refah ugyanis kormánypártként úgy alakította át a közhivatalokban a munkarendet, hogy a tisztviselök a Ramadán idején is tudjanak böjtölni. Ezen az intézkedésükön kívül alapvetően a párt vezetőinek kijelentését hozták fel a párt feloszlatásának indokaként. Ugyanis a párt választási programjában elfogadta a szekularizmus elvét és egyéb cselekményeivel sem utalt arra, hogy az állam vallási semlegességét valamely irányba elmozdítaná.

A strasbourgi bíróság kimondta a Refah-ügy kapcsán, hogy az állampolgárok - még többségi határozat mellett sem - mondhatnak le a demokratikus intézményekről, úgy, mint a felelős törvényhozói vagy igazságszolgáltatási hatalomról, s ebben a tekintetben irreleváns, hogy a kedvezményezett szervezet szekuláris vagy vallási. Egy párt ennek megfelelően csak oly’ módon folytathat kampányt az állam alkotmányos alapjainak megváltoztatására, ha az általa használt eszközök törvényesek és demokratikusak. ${ }^{315}$ (Bár pont ez a megközelítés teszi szükségessé, hogy egy alkotmányos rendszer rendelkezzen militáns, önvédelmi elemekkel.)

Sajó megjegyzi ugyanakkor, hogy bizonytalanság esetén nincs helye preventív büntető szankcióknak egy párt ellen, ugyanakkor a - tekintettel a vizsgált ország történelmére és a napjainkban zajló radikális iszlámizmus rapid terjedésére - jogszerüek lehetnek egyes demokrácia-védő lépések. Még akkor is, ha a közvetlen jogalapot - a párt hivatalos programjától függetlenül - pusztán a párt vezető tisztségviselőinek megnyilatkozásai adják, ha ezek egyes demokratikus alapintézmények felszámolását célozzák és nem zárják ki egyértelműen az erőszakot. ${ }^{316}$ Sajó kiemeli, hogy a pártok betiltásához nem szükséges, hogy bűncselekmény valósuljon meg. Elegendő, ha a párt programja, illetve a párttagság magatartása totalitárius irányba mutat. Példának pedig felhozza az 1950-es években betiltott Sozialistische Reichsparteit, amely belső struktúrájában és a vezetők nyilatkozatában fedte fel politikai programjának valódi arcát. ${ }^{317}$

Az Egyesült Államok is megtette a szükséges lépéseket a politikai szélsőségeivel szemben, bár vitatható módon, ez első sorban a baloldali szélsőségeket érintette, ${ }^{318}$ míg a szegregációt és

\footnotetext{
315 A Refah Partisi és Mások v. Törökország 41340/98, 41342/98 és 41343/98.

316 SAJÓ, p. 60.

317 SAJÓ, p. 58.

318 J. Edgar Hoover köztudomásúan kerülte a szervezett bűnözéssel való összetüzést és első sorban a politikai szélsőségekkel, mint a nácikkal, kommunistákkal és a '60-as évek polgárjogi mozgalmaival foglalkozott.
} 
fehér felsőbbrendűséget hirdető politikai tömörülések a mai napig hozzájárulnak a legfontosabb politikai választások eredményéhez. ${ }^{319} \mathrm{Az}$ ún. vörös veszedelem korszakában, amelyet McCarthy nevével szoktak összekötni, született az Egyesült Államok történetének egyik legvitatottabb törvénye: a Communist Control Act of 1954, amelyet elöször jogtudomány is támogatott, ${ }^{320}$ majd később józanabb vélemények is születtek. ${ }^{321}$ A törvény azzal, hogy az Amerikai Kommunista Pártnak megtagadja a politikai párt mivoltát és azt csak egy összeesküvés eszközének titulálja, ${ }^{322}$ gyakorlatilag változatlanul biztosítja az egyesülési jogot és véleménynyilvánítás szabadságát minden amerikai állampolgár számára, ugyanakkor ezt a csoportosulást és minden jogutódját véglegesen kizárja a politikai versenyből. ${ }^{323}$

Fox és Nolte két nagyobb és két kisebb, egymással korreláló kategóriába sorolja a terrorizmusra adott demokratikus válaszokat. A demokratikus államok egyfelől procedurális vagy szubsztantív módon rendezkedtek be. Másfelől, a terrorizmus által fenyegetett államok aktívan (militánsan) felléphetnek a veszéllyel szemben, vagy passzívan (toleránsan) reagálhatnak arra. Fox és Nolte utóbbiba sorolja azokat az államokat is, amelyeknek a jogrendszere egyébként biztosítana megfelelő eszközöket az aktív fellépésre, azonban valamilyen okból kifolyólag azzal még sem élnek. A két-két korreláló meghatározás összepárosításával Fox és Nolte összesen négy nagyobb kategóriát határoz meg a demokratikus államok által a terrorizmusra adott válaszok tekintetében.

A procedurális toleráns demokrácia jellemzője, hogy nem korlátozza semmilyen szubsztantív szabály a parlament müködését, az alkotmány módosítására is ennek megfelelően, korlátozás mentesen van lehetőség, illetve a legtöbb alkotmányjogász ${ }^{324}$ nem tekinti alkotmányosnak és ezért nem támogatja a pártok betiltását arra hivatkozva, hogy hiányzik a megfelelő alkotmányos szintű felhatalmazás erre. Ezek az államok nem fogják alkotmányos szintre emelni a militáns fellépés eszközeit, azonban, ha mégis, akkor kizárólag abban esetben alkalmazzák, ha

\footnotetext{
319 https://www.washingtonpost.com/news/post-politics/wp/2016/11/01/the-kks-official-newspaper-hasendorsed-donald-trump-for-president/ (letöltés dátuma: 2019. 09. 29.)

${ }^{320}$ The Communist Control Act of 1954. The Yale Law Journal 1955/5., pp. 712-765.

${ }^{321}$ Carl A., AUERBACH: The Communist Control Act of 1954: A Proposed Legal-Political Theory of Free Speech.

In: The University of Chicago Law Review 1956/2., pp. 173-220.

${ }^{322}$ Communist Control Act of 1954 Sec. 2.

${ }^{323}$ Uo. Sec. 4. (b)

${ }^{324}$ Gordon, SMITH: Die Institution der politischen Partei in Großbritannien. In: Parteienrecht im europäischen Vergleich (szerk. Dimitris, Tsatsos) 1990., p. 304, 329; Lawrence W., BEER: Constitutionalism and Rights in Japan and Korea. In: Constitutionalism and Rights (szerk. Louis, Henkin, Albert J., RosenTHAL) 1990., p. 225. , 235.
} 
ténylegesen erőszakosan lépnek fel az adott párt részéről. Fox és Nolte ide sorolja az Egyesült Királyságot, Botswanát és Japánt.

A procedurális militáns demokrácia a Fox és Nolte által meghatározott valamennyi kategóriánál hatékonyabban és vehemensebben lép fel a veszélyt jelentő politikai szélsőségekkel szemben. Tipikusan az Egyesült Államok által az 1940-es és 1950-es években alkotott releváns jogszabályok azok, amelyek ebbe a kategóriába sorolhatók. Először az 1940es Smith Act betiltotta azokat a csoportosulásokat, amelyek erőszak alkalmazásával akarták megszerezni a hatalmat. Majd az 1950-es Internal Security Act, amely kötelezővé tette azon pártok regisztrációját, amelyeket felforgató elemeknek tituláltak a hatóságok. Végül, az 1954es Communist Control Act, amely minden jogot és kiváltságot megtagadott az Amerikai Kommunista Párttól és jogutódjaitól.

A szubsztantív toleráns demokrácia sajátja, hogy alapvetően nem alkalmazza a meglévő szabályait a szélsőséges politikai tömörülésekkel szemben. Fox és Nolte ide sorolja Franciaországot, azonban megjegyzik, hogy ott alkalmazták a meglévő szabályaikat, ugyanakkor kerülték a nagyobb pártokat és csak a kisebbekkel szemben léptek fel. Ezért jellemző, hogy ezekben az államokban az alkotmány megjelöl egy-egy konkrét értéket (pl. az állam területi integritása vagy szekularizmusa), illetve egy szűkebb alkotmányos magot, amelyet semmilyen körülmények között nem lehet megváltoztatni. Így kizárják annak a lehetőségét, hogy a hatalomra kerülő szélsőséges csoportosulások demokratikusan felülírják a jogrendet. További lehetőség, hogy előírják a pártok számára a demokratikus értékek kötelező tiszteletben tartását, vagyis ezen értékek utólagos elengedését sem teszi lehetővé a pártok számára. Végül, nagyon kivételes esetben nem zárja ki annak lehetőségét, hogy az egyesülési joghoz kapcsolódó és konkrétan megjelölt korlátozásokat vezessenek be, ugyanakkor erre kizárólag az alapvető demokratikus értékek védelméhez szükséges mértékben kerülhet sor. Fox és Nolte Franciaország mellett ide sorolja még Kanadát és Indiát.

A szubsztantív militáns demokrácia a fentieknél szélesebb körben alkalmazható szabályokat fog bevezetni a politikai szélsőségekkel szemben és ezeket nagyobb gyakorisággal fogja alkalmazni. Fox és Nolte erre hozza példaként az 1950-es években Nyugat-Németországban a már említett Sozialistische Reichspartei és a Németországi Kommunista Párt betiltására hozott intézkedéseket. Ezeket a döntéseket csupán az alapozta meg, hogy az említett pártok meg akarták dönteni Németország szabad demokratikus rendjét, miközben közvetlenül erre 
irányuló lépéseket nem tett senki a pártok részéről. Továbbá a demokratikus rendszert követlenül és ténylegesen semmi nem fenyegette. Fox és Nolte ide sorolja még Németország mellett Izraelt és Costa Ricát.

Összességében elmondható, hogy Fox és Nolte egy átlátható és jól strukturált rendszert alkotott, ugyanakkor az egyértelmü kategóriák megalkotásakor nem kalkulálták bele, hogy a közjogi rendszerek nem sablonokra épülnek, illetve nagy szerepet játszik az alkotmányos szabályok megalkotásakor és későbbi alkalmazásakor a tradíció. Egy procedurális demokrácia jellegéből adódóan nem kellene, hogy a pártok betiltásához folyamodjon, ugyanakkor a gyakorlat azt mutatja, hogy megközelítőleg azonos vagy nagyobb számban élnek ezzel az eszközzel. Továbbá Fox és Nolte rendszerezésében megoldhatatlan problémának tủnik, ha egy-egy állam több kategóriát is kimerít, mint például Spanyolországnak a baszk nacionalista pártokkal szemben alkalmazott gyakorlata. 


\subsection{A militáns demokrácia 21. századi alkalmazásának gyakorlata}

A militáns demokrácia eredeti értelmezésében a politikai versenyből zárta ki azokat a pártokat, amelyek rejtett célja a demokratikus államrend és a plurális demokrácia megdöntése volt. Megalkotásakor ${ }^{325}$ a koncepció a tömegpártokkal volt hivatott eredményesen felvenni a versenyt, azonban a 21. századra a politikai versenyt nem a pártok hagyományos struktúrái és az állandó aktív tagok (támogatók) nyilvántartott tábora döntötte el. A véleménynyilvánítás szabadsága, illetve alkotmányos korlátai különösen fontos részét képezik az alapjogok gyakorlati érvényesülését és a politikai eredményességet vizsgáló értékeléseknek. ${ }^{326}$ Ezért is fontos változás, hogy a korábbi párt-mozgalmi tevékenység helyett a politikai tevékenységre fókuszál a jogalkotó, így annak eszközeihez és módszereihez nyúl, ha a politikai tevékenyéget kívánja szabályozni. Így kerültek előtérbe a korábban széles körben alkalmazott konkrét pártbetiltások helyett azon kifinomultabb eszközök, mint a véleménynyilvánítás szabadsága és azon belül is konkrétan a politikai szereplök és véleményformálók által alkalmazott egyes kommunikációs eszközök.

A dán lap, Jyllands-Posten 2005. szeptember 30-án közölt néhány karikatúrát ${ }^{327}$ Mohamed prófétáról, illetve az iszlámot a terrorizmussal azonosította. A lap, és 16 másik 2008-ban újra közölte a képeket, újabbakkal kiegészítve azokat, mindezt a véleménynyilvánítás szabadságának indokolatlan korlátozására és az önkorlátozás veszélyeire hivatkozva.

Egy másik esetben ugyanakkor - ugyancsak az állam alkotmányos rendjére hivatkozva cenzúrázták Ausztriában az osztrák soros elnökséget köszöntő nagyjából 150 db közterületen elhelyezett plakátot, amelyeken ruhátlan modellek maszkban állami vezetőket jelenítettek meg. A képeken többek között II. Erzsébet, George W. Bush és Jacques Chirac láthatólag közösülnek, illetve egy másik plakáton egy ágyon fekvő ruhátlan nő csak egy harisnyát visel, amelyen az EU szimbólumai vannak. Országszerte tiltakozások követték a plakátok kihelyezését a katolikus egyház és az ellenzéki pártok részéről. Végül a kormány engedett és a

\footnotetext{
${ }^{325}$ Bár Sajó felhívja a figyelmet arra, hogy a militáns demokrácia eszközeit már a második világháború előtt is alkalmazták az államok, különösen a párt-betiltások és az egyenruha viselés korlátozásának formájában. SAJÓ, p. 56.

${ }^{326}$ Koltay András: Az új média és szólásszabadság. A nyilvánosság alkotmányos alapjainak újragondolása. Wolters Kluwer, Budapest 2019., pp. 37-38.

${ }^{327}$ http://multimedia.jp.dk/archive/00080/Avisside Muhammed-te 80003a.pdf (letöltés dátuma: 2019. 09. 29.), részletesebben lásd Peter, HeRVIK: The Danish Muhammad Cartoon Conflict. Current Themes in IMER Research Number 13. Malmö University 2012 https://www.mah.se/upload/Forskningscentrum/MIM/CT/CT\%2013.pdf (letöltés dátuma: 2019. 09. 29.)
} 
plakátokat a közfelháborodásra tekintettel leszedték. ${ }^{328}$ Nem példa vagy előzmény nélküli Ausztria állami cenzúrája.

Egy olyan társadalomban, ahol nem kell nagy létszámú párttagság és nem is feltétlenül kell komolyan kiépített pártszervezet ahhoz, hogy politikai sikereket érjen el valaki, el kell gondolkodni azon, vajon alkalmas-e még az egyszerű pártbetiltás, mint szankció alkalmazása a szélesőséges elemek és gondolatok kizárására. Pártot alapítani sok országban kifejezetten egyszerü, hiszen általában egyszerü regisztrációhoz kötött. Vagyis, egy szélsőséges nézetei miatt betiltott párt helyett szinte már másnap regisztrálhat a vezetés egy újabbat. A név, a brand változhat, azonban a politikai cél, az eszmeiség az állandó, amelyet viszont sokszor csak a résztvevők egyezőségében érhetünk tetten.

Ezért Sajó arra tesz ${ }^{329}$ javaslatot -, hogy a militáns önvédelmi intézkedések eredményeként feloszlatott pártok egykori vezetői számára a párt alapítási jog korlátozásának hatálya tovább tartson, mint az aktív választójog korlátozása. Különösen a spanyolországi Herri Batasuna párt és az első - eredeti - párt, majd a Batasuna párt betiltását követően a vezető tisztségviselők által alapított újabb és újabb klónok sora ${ }^{330}$ mutat rá a probléma gyökerére. A baszk radikálisok körében a nacionalizmus erősen vegyül a tradicionális baloldali eszmékkel. Ezért a 2001-ben alapított Batasuna párt ideológiai és jogelődszervezetei között szerepel a Herri Batasuna, a Herriko Alderdi Sozialista Iraultzailea és általában az izquierda abertzale (radikális nacionalista baloldal).

A Herri Batasuna 1979 és 1996 között minden alkalommal indult a baszkföldi választások mellett az országos választásokon is, és rendszerint meghaladta a 15\%-ot az elnyert szavazatok aránya. Mi több, az átlagos 3 mandátum helyett 1986-ban öt mandátumot szerzett a Cortezben. Közel 20 éves demokratikus müködést követően nehezen indokolható a párt betiltása. Erre akkor került sor, amikor a baszk társadalom szerkezete és a politikai aktivitása jelentős

\footnotetext{
328 Austria Drops „Porno” Posters From Sex-ed up EU Campaign, Deutsche Welle 2005. 12. 30. http://www.dw-world.de/dw/article/0,2144,1839922,00.html (letöltés dátuma: 2019. 09. 29.)

${ }^{330}$ Ezek a következök (a párt betiltásának évével): Herri Batasina, Euskal Herritarrok Batasuna (2003), Autodeterminaziorako Bilgunea és mások (2003), Herritarren Zerenda (2004), Aukera Guzitiak (2005), Abertzale Sozialisten Batasuna (2007), Eusko Abertzale Ekintza (2007), Abertzale Sozialistak (2007), Eusko Abertzale Ekintza (2008), Euskal Herrialdeetako Alderdi Komunista (2008), Askatasuna (2009), Demokrazia Hiru Milioi (2009), Inziatiba Internazionlista - Herriren Elkartasuna (2009), Sortu (2011), Bildu (2011). Forrás: Angela, BOURNE: The proscribtion of parties and the problem of 'militant democracy'. Journal of Comparative Law 2012/1. (a továbbiakban: BoURNE), pp. 196-213.
} 
átalakuláson ment keresztül. A lépéssel azt kívánta elérni a spanyol kormány, hogy a baszk emberek forduljanak el az erőszakot kínáló ETA-tól és annak politikai kirakatpártjától, helyette pedig a spanyol alkotmányban is megjelenő politikai pluralitás mellett tegyék le a voksukat. ${ }^{331}$

A Knesszet közel három évtizeddel a Kach párt miatt meghozott intézkedéseit követően véglegesen kívánta rendezni az állam- és alkotmányellenes propagandát hirdető parlamenti képviselök mandátumának sorsát, ezért 2016-ban hosszas vitákat követően elfogadta azt a törvényt, ${ }^{332}$ amely módosította a Knesszetről szóló törvényt és így lehetővé vált, hogy a mandátumuktól megfosszák az érintett képviselöket.

${ }^{331}$ BOURNE, pp. 196-213.

${ }^{332}$ https://law.acri.org.il/en/2016/07/19/update-mk-suspension-bill/ (letöltés dátuma: 2019. 09. 29.) 


\subsection{A militáns demokrácia és a nemzetközi terrorizmus összefüggései}

A militáns demokrácia és a nemzetközi terrorizmus összefüggéseit négy szempontból közelíthetjük meg, illetve ezek alapján négy megállapítást tehetünk. A militáns demokrácia eszméjének születésekor merőben más képet mutatott a politika eszköztára, valamint a pártpolitizálás terepe és szervezete is jelentősen eltért a ma tapasztalhatóktól. A tömegpártok helyett ma online pártok (is) érnek el számottevő választási sikereket, továbbá a pártfinanszírozást a mecénások és a párttagság helyett - a kampány idejére - jelentős részben az állam vállalja át. A militáns demokrácia elsődleges célpontjai a baloldali és a jobboldali szélsőségek voltak, hiszen célja a társadalom integritásának és prosperitásának tekintett visszafogott politikai kultúra védelme volt. Széleskörbe történő elterjedése a második világháborút követő évtizedre tehető. Értelmezése és gyakorlati alkalmazása azonban nagy mértékben függ a helyben adott, már eleve létező általános politikai kultúrától és ezzel összefüggésben a történelmi tapasztalatoktól. Vagyis, megbonthatatlan fogalmi egységről kevésbé, sokkal inkább a gyakorlatban kimunkált eszköztárról beszélhetünk, amely alkalmas az adott társadalom, politikai közösség céljainak elérésére. Szemléltető példa erre, hogy Európában észrevehetően nagyobb jelentőséget tulajdonítottak a szélsőjobboldali kezdeményezéseknek, míg az Egyesült Államokban inkább a szélsőbaloldali eszméket üldözték.

A ma tapasztalható nemzetközi terrorizmus a 20. század harmadik harmadáig nem alakult ki, és a terrorszervezeteket alapvetően a territorialitás határozta meg. A nemzetközi terrorizmus elterjedéséig nem is tünt egyértelmünek, hogy a szélsőséges politikai retorikát és a terrorizmus irányába mutató erőszakosságot összekapcsolják és egységesen lépjenek fel ellene. A territorialitásból következik, hogy a terrorizmus elsődleges célpontja és terepe a 20. század szignifikáns részében a nemzeti politikák meghatározása volt. Legyen az őshonos kisebbség politikai identitásának hangsúlyozása vagy a jobb- és baloldali politikai szélsőségek programjának propagálása. A megbotránkoztató vagy erőszakos fellépések első sorban a rendkívül hatásos üzenetközvetítő jellegük miatt népszerüek a szélsőséges pártok körében eredményként nem a rendszer megváltozását várják, hanem az áhított ismertséget. A klasszikusnak tekintett, lokálisan szerveződő terrorizmus toborzási és utánpótlási módszerei alapvetően a személyes ismertségre korlátozódtak. A nemzetközi terrorizmus elterjedése és a globális információs forradalom más megvilágításba helyezték a korábban lenézett nyilvánosságot kereső fellépést. Tömegbázist valóban nem lehet rá építeni, de arra 
messzemenőkig alkalmas, hogy éppen ahhoz a címzetthez jusson el, aki aztán hajlandó lesz terrorcselekmény elkövetésére. A militáns demokrácia és a terrorizmus összefüggéseit korábban nem ismerték fel, a 21. századra ugyanakkor egyértelművé vált, hogy a megelőzés és deradikalizáció sikeréhez elengedhetetlenek a militáns demokrácia által kimunkált eszközök.333

A militáns demokrácia legfontosabb jellemzője, hogy alapvetően puha eszközökkel él. Ez különösen a büntetöjog ultima ratio jellegével összevetve, vagy a különleges jogrendhez képest szembetünő, főként, mivel utóbbi időnként és átmenetileg jogrendszeren túli eszközökhöz folyamodik. A militáns demokrácia eszközei sokszor nem öltenek jogi jelleget, mint például az izraeli Kach párttal szemben tanúsított intézményi és személyes magatartás az állami vezetők részéröl. Legyenek bármennyire is puhák, és eseti alkalmazásuk miatt törékenynek vagy súlytalannak látszók a militáns demokrácia eszközei, eredményességük többre is mutathat az egyszeri tüneti kezelésnél. Előfordulhat, hogy a jogrendszer részévé teszi őket a jogalkotó abból a célból, hogy hosszútávon zárja ki a szabályozatlanság vagy az elnéző joggyakorlat jóvoltából megvalósuló joggal való visszaéléseket. ${ }^{334}$ Ahogy ez jól látható a véleménynyilvánítás szabadságát korlátozó rendelkezések egyre szofisztikáltabbá válásában. Végső soron ezáltal a militáns demokrácia ugyanolyan jellemzőket mutat, mint a veszélyre hivatkozással megvalósuló jogalkotási narratíva. Valamennyi militáns demokráciához vagy terrorellenességhez köthető jogrendszeri változtatás - jellemzően további korlátozások bevezetése - ugyanúgy a normál jogrend részévé válik, vagyis alakiságát tekintve, főszabály szerint nem különbözhetnek sem egymástól, sem más tárgyú normától.

A militáns demokrácia születésekor teljesen más képet mutatott az európai társadalom, amely azóta sokkal heterogénebb lett és számos nyugat-európai ország rendelkezik szignifikáns muszlim kisebbséggel. A második és harmadik generációs muszlim bevándorlók frusztráltsága részben táptalaja lehet a radikális eszmék kibontakozásának. ${ }^{335}$ A terrorizmushoz is vezető radikalizálódás megelőzése során ezért a kiszolgáltatott és a társadalom perifériájára szorult

\footnotetext{
${ }^{333}$ Kent, RoAch: Anti-Terrorism and Militant Democracy: Some Western and Eastern Responses. In: SAJÓ, András (ed.) Militant Democracy. Eleven International Publishing, Amsterdam, 2004., pp. 171-207.

${ }^{334}$ Lásd a Knesszet által 2016-ban elfogadott törvényt, amely egy olyan jogi helyzetre adott választ (ti. Izrael ellenes politikai párt az alaki szabályosság betartásával működik a Knesszetben), amely már három évtizeddel korábban a Kach párt kapcsán feltünt a jogalkotónak. Akkor azonban megelégedtek a hosszadalmas bírósági úttal és az egyedi eset miatt nem keletkezett szabályozási kényszer.

${ }^{335}$ Radicalisation, Recruitment and the EU Counter-Radicalisation Strategy. In: Transnational Terrorism, Security and the Rule of Law 2008. november 17., p. 18. http://www.gdr-elsj.eu/wp-content/uploads/2014/02/doc2-WP4Del-7.pdf (letöltés dátuma: 2019. 09. 29.); SzIJÁRTÓ Lívia: Alkalmazott pszichológiai módszerek a terrorizmus elleni harcban. Doktori értekezés 2018.
} 
személyek körében nem csak a szegényebb muszlim lakosságra irányul a figyelem, hanem a társadalom nem-muszlim tagjaira is. ${ }^{336} \mathrm{~A}$ nemzetközi terrorizmus a radikális iszlámizmus mellett a szintén radikális iszlám-ellenességet is megalapozhatja, amely melegágya a szélsőjobboldali eszmék újra erősödésének. Mindez pedig magával hozza a politikai közélet radikalizálódását, ahogy látszik a 9/11 utáni nemzeti és nemzetközi politikai diskurzus tematizálását illetően, amelyben közel másfél évtizeden keresztül az egyik meghatározó téma ${ }^{337}$ a terrorizmus volt. A radikális eszmék tartós jelenléte a közéleti párbeszédben rendszerszintű eltolódást hozhat, amely a párbeszéd szintjéről a normák világában is manifesztálódhat.

A nemzetközi terrorizmus előretörése és a telekommunikáció 21. század elején végbe ment elképesztő fejlődése komoly hatással vannak egymásra, amely többről szól, mint a terroristák leplezett kapcsolattartása vagy a toborzás. A terroristák célja, hogy a célpont kiválasztásával, a cselekmény brutalitásával vagy az alkalmazott eszközökkel alapvetően félelmet keltsen a társadalomban, és ami ennél fontosabb, erre tekintettel valamilyen reakciót váltson ki a kormányzat részéröl. A nemzetközi terrorizmus erősíti az idegengyülöletet és a bizalmatlanságot a társadalomban, valamint nagy mértékben hat az emberek hatalomhoz való viszonyára. A biztonság ezért tartósan vált a közbeszéd tárgyává és így a politika is kénytelen adekvát válaszokat adni a terrorizmus jelentette veszélyre. A nemzetközi terrorizmus nemzetközi jellege és a 9/11 utáni néhány évben elkövetett pusztító terrortámadások egy sor terrorellenes szabály megalkotását tették indokolttá. ${ }^{338}$ Ezen szabályok egy része a politikai diskurzust és a közbeszédet hivatott finoman befolyásolni, ezért mondhatjuk, hogy a terrorellenes szabályok egy részének integrációja a militáns demokrácia körébe elkerülhetetlen volt. A militáns demokrácia és a nemzetközi terrorizmusra adott politikai és a jogi válaszok több irányból közeledtek egymás felé az elmúlt évtizedekben. A politikai pártok mellett a közéleti radikalizáció azért kerülhetett be a militáns demokrácia célpontjai közé, mert erre a tömegpártok eltünése óta most, a nemzetközi terrorizmus folyamatos jelenléte miatt van újra komolyabban lehetőség. Ezek alapján kijelenthető, hogy a militáns demokrácia egy újabb értelmezéséről, fejlődési stádiumáról beszélhetünk.

\footnotetext{
${ }^{336}$ Radicalisation, Recruitment and the EU Counter-Radicalisation Strategy. In: Transnational Terrorism, Security and the Rule of Law. 2008. november 17., p. 18. http://www.gdr-elsj.eu/wp-content/uploads/2014/02/doc2-WP4Del-7.pdf (letöltés dátuma: 2019. 09. 29.)

${ }^{337}$ A gazdasági biztonság és a migráció mellett.

${ }^{338}$ Ld. U.S.A.P.A.T.R.I.O.T. Act, az Egyesült Királyság majd' egy tucat terrorizmussal kapcsolatosan született törvénye, a 2017-1510. számú törvény Franciaországból és nyugodtan ide sorolhatjuk Magyarország Alaptörvényének hatodik módosítását.
} 


\section{A KÜLÖNLEGES JOGREND}

A különleges jogrend elméleti alapját a 17-18. század abszolutista államában látta Carl Schmitt, aki szerint a 19. század liberális, minimumra korlátozott államában „elveszik az állam és a társadalom, valamint a kormány és a nép megkülönböztetése.”339 Schmitt szerint a társadalom által irányított államban a háborúra való felkészülés jegyében szükséges a társadalom tagjainak fizikai, lelki és szellemi felkészítése (kiképzése), amelyet a háborút megelőző totális mozgósítással azonosít. ${ }^{340}$ Ezzel párhuzamosan kimondja, hogy a plurális állam ellentéte a totális állam, ${ }^{341}$ amely valójában egy különlegesen erős állam. ${ }^{342}$ Hiszen Schmitt szerint az államok sajátos természetéből fakad, hogy folyton arra törekszenek, hogy birtokukba kerítsék azokat a hatalmi eszközöket, amelyek politikai uralmukhoz szükségesek. A totális háború és a totális ellenség adja Schmitt szerint a totális állam szükségszerüségét. A háború ugyanis Schmitt szerint már nem a konfliktus eldöntéséről szól, hanem az ellenség megsemmisítéséröl. ${ }^{343}$

A különleges jogrend anyagi és alaki jogi értelemben véve is különleges, a szó legszorosabb értelmében. A szokásostól eltérő minőségét két síkon is észlelhetjük, hiszen egyszerre jelent eltérést az állam és az egyének kapcsolatában és az állam belső viszonyaiban. A különleges jogrend - nevében is utal rá - továbbra is változatlanul jogrend lesz, csak eltérő a normálistól. Az eltérés mibenlétét szükséges elméleti és normatív módon meghatározni, amely így keretet ad a normál jogrendtől való eltérésnek. A keretekre azért van szükség, mert lényeges szempont, hogy a különleges jogrend nem - lehet - tényleges és végleges alternatívája normál jogrendnek. Vagyis a különleges jogrend viszonylagos (valamilyen fizikai manifesztációnak lehet csak a következménye), illetve időben korlátozott. Jogi eszközeit tekintve egyszerre korlátozott és látszólag korlátlan, hiszen bevezetésének idejére a kivételes hatalommal felruházott jogalkotó az alkotmányos minimum garanciák betartásának kötelezettségétől eltekintve bármit megtehet. Jogalkotási eljárására vonatkoznak ugyan a jogalkotásra jellemző alapvető szabályok, úgymint a nyelvtani, logikai és rendszertani elvárások, valamint a közzétételi kötelezettség, ugyanakkor

\footnotetext{
${ }^{339}$ Carl, Schmitт: Az állami és politikai. A politika fogalma (1927). A birodalmi elnök mint az alkotmány öre. In: Államtan. Írások a XX. századi általános államtudomány köréböl. Szerk.: TAKÁCs Péter. Szent István Társulat, Budapest 2003. (a továbbiakban: SCHMITT), pp. 130-182., 260-288

${ }^{340}$ SCHMitT, p. 215.

${ }^{341}$ Schmitt a Mussolini által használt stato totalitario kifejezést vette át. SCHMITT, p. 223.

${ }^{342}$ Uo.

${ }^{343}$ KARDOS, p. 44.
} 
a politikai vagy alkotmányos normakontroll lehetősége a gyakorlatban nem feltétlenül képes teljeskörüen érvényesülni, illetve a retrospektív felülvizsgálatoknak inkább kedveznek a különleges jogrendi időszak körülményei. ${ }^{344}$

A cél nem a szabadságjogok felfüggesztése, ez önmagában csupán eszköz. A különleges jogrendben alkotott jogszabályban meghatározott jogkorlátozó intézkedés céljának összhangban kell lennie a különleges jogrend bevezetésének Alaptörvényben meghatározott céljával. ${ }^{345}$ Ez a cél minden esetben a normál jogrendhez való visszatérés. A különleges jogrend bevezetése is a normál jogrend legalitásának keretei ${ }^{346}$ között történik, normatív meghatározottsága van különlegessége ellenére is. Az előíró rendelkezés, még ha némileg módosított alkotmányos környezetben is kívánja meghatározni a címzettek cselekvését, ugyanazokkal a formai kritériumokkal rendelkezik, mint bármely más jogforrás, amely a veszélyhelyzetet megelőzően keletkezett. A demokratikus intézményrendszer hatékonyan képes ellenállni az olyan külső hatásoknak, amelyek erőszakkal próbálnak változtatni rajta, de nehezebben veszi fel a versenyt a belülről ható, a demokráciát lassan erodáló folyamatokkal. Nem mindegy tehát, hogy a vélt vagy valós veszélynek milyen politikai hatásai vannak, elsődlegesen: indukál-e valamilyen politikai alternatívát. Egy állam megszünik hatékonyan müködni, ha nem képes a továbbiakban a legfontosabb operatív döntéseket meghozni és azokat végrehajtani. A végrehajtásban leginkább a kormány érintett, így kézenfekvőnek látszik kizárólag a kormányra fókuszálni, de az állam funkcionalitásához hozzátartozik a parlament és az igazságszolgáltatás is. A nem hatékony állam az emberek közhatalomba vetett bizalmát elhalványítja és így életük, testi épségük és jogaik védelme érdekében más eszközökhöz fognak fordulni. A döntésképesség ugyanakkor az állami szereplők körében is kohéziós erőként hat nem csak széleskörben a társadalomban. Így hiánya a közhatalommal felruházott személyek és szervek céltalanságához, majd megszünéséhez vezet. Ahogyan a láz sem a test normális

\footnotetext{
${ }^{344}$ JAKAB András - TILl Szabolcs: A különleges jogrend. In: TRÓCSÁNYI László - SCHANDA Balázs (szerk.): Bevezetés az alkotmányjogba. HVG-Orac, Budapest 2013. (a továbbiakban: JAKAB - TILL), pp. 479-503.; CsinK Lóránt: Mikor legyen a jogrend különleges? In: Iustum Aequum Salutare 2017/4. (a továbbiakban: CsINK), pp. 7-16; Friedrich, KOJA: Állami szükségállapot és a szükségállapotra vonatkozó jog. In: Államtan (szerk. TAKÁCS Péter) Szent István Társulat Budapest 2003., pp. 797-817.

${ }^{345}$ A Nemzeti Adatvédelmi és Információszabadság Hatóság ajánlása a különleges jogrend szabályozásának információs alapjogi kereteiről. NAIH20160128AJ-NL-S p.6

${ }^{446}$ TÓTH Árpád: A kivételes hatalom jogi szabályozása Magyarországon az elsö világháború elöestéjén. JATE ÁJK tudományos bizottsága, Szeged 1996., pp. 7-11.

Magyarországon ezek sorban: a háború esetére szóló kivételes intézkedésekről szóló 1912. évi LXIII. törvény, a honvédelemről szóló 1939. évi II. törvénycikk, a honvédelemről szóló 1960. évi IV. törvény, a honvédelemröl szóló 1976. évi I. törvény, a honvédelemről szóló 1993. évi CX. törvény, a honvédelemről és a Magyar Honvédségről szóló 2004. évi CV. törvény, végül a honvédelemről és a Magyar Honvédségről, valamint a különleges jogrendben bevezethető intézkedésekről szóló 2011. évi CXIII. törvény.
} 
állapota, úgy a kivételes jogrend sem lehet a jogállamé. A folyamatosan fenntartott ideiglenesség, valójában zsarnokság, és ez ellen jogosan emelhetünk kifogást. ${ }^{347}$ A különleges jogrend a demokrácia immunrendszerének válasza arra a súlyosan fenyegető veszélyre, amelyet a demokratikus intézményrendszer normál keretek között nem képes kezelni, illetve a fennmaradás érdekében - még, ha időszakosan is, de - strukturális változásokat követel meg a tág értelemben vett közhatalmi folyamatokban.

${ }^{347}$ Lásd bővebben: SABJANICS István: Minősitett idöszakok az Alaptörvényen innen és azon túl. In: KovÁcs Péter (szerk.): Religio et Constitutio. Budapest, Pázmány Press 2014., pp. 221-232. 


\subsection{A különleges jogrendi szabályok rendszerezése}

A különleges jogrend bevezetése egyszerre lehetőség és szükség az állam részéről. Akkor kerülhet erre sor, ha az állam nem képes garantálni az emberek (közösségek) biztonságát vagy müködőképessége valamilyen okból nem biztosított. A két szempont láthatóan összefügg, hiszen az állam müködőképessége önmagában nem, csak az emberi tényező szempontjából vehető figyelembe. Jakab András és Till Szabolcs a különleges jogrend bevezetésének igazolását két csoportba sorolja: megkülönbözteti az államközpontú és az alkotmányközpontú különleges jogrendi megalapozottságot. Az államközpontú felfogás esetében a különleges jogrend bevezetését a szükséghelyzetből fakadó íratlan szabály alapozza meg, amely valójában a pozitív jog felett áll, így korlátozására sem a pozitív jog keretei között van lehetőség. Az alkotmányközpontú megközelítés ezzel szemben a különleges jogrendet egyfajta alkotmányos lex specialisként kezeli, vagyis bevezetését, fennállásának idejét és megszüntetését egyaránt alkotmányosan megalapozottnak és definiáltnak kell tekinteni. ${ }^{348}$ A fizikai veszélyek leküzdésére a demokratikus jogrendek kétféleképpen reagálhatnak: (1) a jogrend részének tekintik a kivételes szabályokat, amelyek így aztán magát a veszélyt is a jog által értelmezhető, leírható és így a szabályozható valóság részévé teszik, vagy (2) a veszély idejére a demokratikus jogrend érvényesülését korlátozzák, a kritikus helyzet megoldását pedig végső soron a jog érdekében használt, de jogon kívüli eszközöktől várják. Utóbbi esetben azonban hiába a jogrenden kívüli megoldások, az eszközök kiválasztása és alkalmazása során továbbra is törekedni kell a jogállami elvárásoknak való megfelelésre, mivel az események utólagos áttekintésekor már a jogállami garanciális szempontok szerint értékelik a megtett és megtenni elmulasztott cselekményeket. ${ }^{349}$ Ennek hatékony eszköze lehet a normatív módon elöírt vagy a - szinte - korlátlan hatalomgyakorló önkorlátozása folytán érvényesülő fokozatosság. Egy kevésbé pragmatikus, de annál mélyebb ok is szerepet játszhat az eszközök kiválasztásakor a jogrenden kívüli különleges jogrendben: ez pedig az eszmeiség, amely a jogállamiságból fakad. Röviden: ha túl messze távolodunk a jogállamiságtól, bármenyire is annak védelmében ${ }^{350}$ tesszük ezt, csak nagy nehézségek árán találunk vissza hozzá.

\footnotetext{
348 JAKAB - TILL, pp. 470-471.

${ }^{349}$ Nasser, HuSSAIN: The Jurisprudence of Emergency: Colonialism and the Rule of Law. Univeristy of Michigan Press, 2003. (a továbbiakban: HUSSAIN), pp. 16-22.

${ }^{350}$ Vö. az állam védelmi funkciójával, amelyhez lásd Thomas, FLEINER-GERSTER: Az állam és a társadalom céljai és feladatai. In: Államtan - Írások a XX. századi államtudomány köréből (ford.: TAKÁCS Péter), Szent István Társulat, Budapest 2003., pp. 440-452.
} 
A fenti alapvetésekből kiindulva törekszik ezért a jogalkotó a veszélyek normatív leírására, így nemcsak értékalapú megközelítésben kötődik egy jogrend a jogállamisághoz, hanem eljárási keretek által is. Nem feltétlenül gyengébb az egyik a másiknál, azonban az értékalapú megközelítés esetében nagyobb a hangsúly a rendszert müködtető egyes emberek helytállásán, amelyet legfeljebb a bírói gyakorlat képes közvetve befolyásolni. Árulkodó jel az is, hogy a különleges jogrend normatív szabályozását a jogalkotó többnyire alkotmányos szinten rögzíti, amellyel (1) kifejezi a szabályozási cél fontosságát, (2) a jogrend legmagasabb szabályozási szintjére helyezi a kivételes szabályokat, vagyis a rezervátumba helyezett alkotmányos magtól eltekintve a jogrend tényleges alternatívájaként jelöli meg a különleges jogrendet, végül (3) nemcsak a kivételes jogrend bevezetését helyezi normatív keretek közé, de egyúttal a normál jogrend visszatérését is megalapozza. A demokrácia immunitását is alapvetően az előbbi szempontok alapján célszerü értékelni. ${ }^{351}$

A veszélyek normatív leírása látszólag nem jelent fenyegetést a jogállamiságra, sőt annak ellenkezőjét célozza, ugyanakkor az alkotmányos szinten rögzített szabályok természetes módon magukkal hozhatnak egy sor új szabályt, amelyek a tervezett jogalkotás farvizén válnak a jogrend részévé. A normál és a különleges jogrend látványosan elválik egymástól, s ezt alkotmányos szinten is egyértelművé szokta tenni az alkotmányozó. A normál jogrendet alkotó jogszabályok - a később részletezett kivétellel - a különleges jogrendben alkotott jogszabályok függvényében érvényesülnek, azokkal párhuzamosan, míg a különleges jogrendben alkotott jogszabályok csak a legritkább esetben maradnak hatályban a normál jogrendhez való visszatérést követően. Erre alapvetően a két világháborút követően találunk példát, ${ }^{352} \mathrm{de}$ egyébként nem jellemző, mivel a normál jogrendhez való visszatérés egyszerre jelenti, hogy a továbbiakban felmerülő konfliktusok kezelésére ismét alkalmas lesz a rendes körülmények között működő állami szervezetrendszer, valamint azt, hogy mögötte stabil társadalmi konszenzus áll. Ilyen körülmények között nem jellemző, hogy valamilyen különleges jogrendben alkotott jogszabály szabályozási szükségessége és politikai legitimációja tovább éljen. A különleges jogrendben alkotott jogszabályoknál ezért lényegesen nagyobb kihívást jelentenek a jogrendszer kohéziójára nézve a különleges jogrend bevezetését nem megalapozó vélt vagy valós veszélyek jogalkotási reflexiói.

\footnotetext{
351 Vö. SAJÓ, p. 55.

352 Például a háború esetére szóló kivételes hatalom idejének meghosszabbításáról szóló 1920. évi VI. törvénycikk; a népbíráskodás tárgyában kibocsátott kormányrendeletek törvényeröre emeléséröl szóló 1945. évi VII. törvénycikk; az államhatalom gyakorlásának ideiglenes rendezéséről szóló 1945. évi XI. törvénycikk.
} 
A normál jogrendben a jogszabályok elsődleges feladata, hogy a fennálló társadalmi és gazdasági rendet biztosítsák és fenntartsák. A különleges jogrendben alkotott normatív előírások célja és primer feladata a normál jogrendben létező társadalmi és gazdasági rendhez való visszatérés biztosítása. ${ }^{353} \mathrm{Ez}$ egy lényeges különbség, amely a contrario kimondja azt is, hogy különleges jogrendben a jogalkotás célja és tárgya nem feltétlenül egyezik. Ez a mondat tömörsége miatt kifejtésre szorul. A normál és a különleges jogrendben alkotott normatív elöírások egyaránt jogszabályok lesznek, ez nem vitás. ${ }^{354}$ Az Alaptörvény T) cikk (2) bekezdése alapján a Honvédelmi Tanács rendkívüli állapot idején és a köztársasági elnök szükségállapot idején kiadott rendelete jogszabálynak minősül, vagyis olyan általánosan kötelező magatartási szabály lesz mindkettő, amely az 54. cikk alapján akár egyes alapvető jogok gyakorlását is felfüggesztheti, illetve korlátozhatja. ${ }^{355}$ A jogszabályok megalkotásának alaki és tartalmi követelményei tehát a különleges jogrendben is változatlanul fennállnak. A jogalkotásra felhatalmazott szerv jogosult szabályt alkotni, de a jogszabállyal szemben támasztott nyelvtani, rendszertani, logikai stb. elvárások és a megismerhetôség biztosítása változatlanul fennáll, ezektől nem lehet eltekinteni. Mégis más lesz a szabályozás célja és tárgya, mégpedig azért, mert a különleges jogrendben alkotott szabályok érvényessége a különleges jogrend idejére korlátozódik. Vagyis - összehasonlítva a normál jogrendben alkotott jogszabályok időbeli hatályával - megállapíthatjuk, hogy a rendes jogszabályok hatályosulásának időbeli korlátozása egy olyan feltételtől függ, amelyet a jogszabály megalkotásakor ismertek. Ez akkor is igaz, ha a jogszabályt módosítják, vagy a későbbiekben helyezik hatályon kívül. Ezzel szemben a rendkivüli jogszabályok időbeli korlátját ugyanaz a feltétel adja, amely a jogalkotás szükségességét megalapozza. Mindezek alapján az alábbi megállapításokat tehetjük: a normál jogrendben minden jogszabály célja (a fennálló társadalmi és gazdasági rend biztosítása és fenntartása) és tárgya (a fennálló társadalmi és gazdasági rend egy konkrét szegmensének normatív leírása) rész- egész viszonyban áll egymással, és így szorosan összefügg. Ezzel szemben a különleges jogrendben alkotott jogszabályok célja (a különleges jogrendre okot adó

\footnotetext{
353 Vö. JAKAB - TILL, pp. 480-483.

354 VARGA Zs. András: A közigazgatás és a közigazgatási jog alkotmányos alapjai. Dialóg-Campus, Budapest 2017., pp. 149-151.

355 Alaptörvény 54. cikk

„,(1) Különleges jogrendben az alapvetö jogok gyakorlása - a II. és a III. cikkben, valamint a XXVIII. cikk (2)-(6) bekezdésében megállapitott alapvetö jogok kivételével - felfüggeszthetö vagy az I. cikk (3) bekezdése szerinti mértéken túl korlátozható.

(2) Különleges jogrendben az Alaptörvény alkalmazása nem függeszthetö fel, az Alkotmánybíróság müködése nem korlátozható.

(3) A különleges jogrendet a különleges jogrend bevezetésére jogosult szerv megszünteti, ha kihirdetésének feltételei már nem állnak fenn.

(4) A különleges jogrendben alkalmazandó részletes szabályokat sarkalatos törvény határozza meg. ”
} 
állapot mielőbbi megszüntetése és visszatérés a normál jogrendhez) és tárgya (továbbra is a fennálló társadalmi és gazdasági rend egy konkrét szegmensének normatív leírása) bár egy irányba mutat, de élesen elkülönül egymástól.

A különleges jogrendi szabályok bevezetéséről és alkalmazásáról szóló rendelkezések jogi hidat képeznek a tátongó ür áthidalására. ${ }^{356}$ Szerencsés, ha ezeket alkotmányos szinten, de legalábbis megfelelő alkotmányos garanciákkal alkotja meg a jogalkotó. Fontos, hogy nehezen lehessen őket módosítani, de ne legyenek értelemszerüen olyannyira érinthetetlenek, mint az alkotmánynak az a magja, amelynek a védelmére alkották őket eredendően. Ha azonos szintü védettséget élveznének, amely ebben az esetben legfeljebb érinthetetlenséget jelentene, az többféle veszéllyel járna a különleges jogrendre és az alkotmányosságra nézve. Egyrészt, az értékazonosság látszata miatt nem tudna különbséget tenni a jogalkalmazó a többnyire anyagi jogot és értéktartalmat megjelenítő alkotmánymag, ${ }^{357}$ valamint az alaki jogot tartalmazó különleges jogrendi szabályok bevezetéséről és alkalmazásáról szóló rendelkezések között. Másrészt, a különleges jogrend ultima ratio jellege ellenére, bevezetését olyan döntéshozói helyzetfelismerés és reagálás kell, hogy megelőzze, amelyet pragmatikus megfontolásból indokolt bizonyos mértékben rugalmas keretek között tartani. Egy bebetonozott rendszer, amely a bizonytalant hivatott kezelni, a szükségesség követelményének sokkal ritkábban fog megfelelni, mint egy megfelelően rugalmas, így az esetek többségében vagy túl megengedő ${ }^{358}$ lesz, vagy túl szigorú.

A különleges jogrend kapcsán legtöbbször hivatkozott jogelv, salus populi suprema lex ${ }^{359}$ szoros összefüggésben a protego ergo obligo elvével ${ }^{360}$ azt a látszatot kelti, mintha a különleges helyzetekben, amelyeket a jogállam nem, vagy csak rendkívüli nehézségek árán tud kezelni, az állam-egyén relációban jelentős mértékben eltolódnak a fókuszpontok. Az egyén szinte

\footnotetext{
356 A pakisztáni legfelsőbb bíróság 1955-ös, a parlament feloszlatásáról szóló államfői döntésről szóló határozatának kezdő gondolatai. Lásd HuSSAIN, p. 1.

357 A kifejezéssel nem az osztrák alkotmányjogászok által kidolgozott integrációálló alkotmánymagra (integrationsfester Verfassungskern) utalok, hanem azokra a szabálycsoportokra és egyedi alkotmányos rendelkezésekre, amelyeket különleges jogrend bevezetését követően sem áll módjában felfüggeszteni a kivételes hatalom gyakorlójának. Vö. VARGA Zs. András: A mag-alkotmány védelmében. In: Pázmány Law Working Papers 2011/2. http://plwp.eu/docs/wp/2012/2011-02.pdf (letöltés dátuma: 2019. 09. 29.)

358 Lásd a weimari alkotmány különleges jogrendi szabályait, SzABÓ István: Különleges jogrend a weimari alkotmányban. A fogalmak pontossága - a jogalkalmazó mérlegelési lehetősége. In: Iustum Aequum Salutare 2017/4., pp. 127-141.

${ }^{359}$ VARGA Zs. András: Eszményből bálvány? Századvég, Budapest 2015., p. 29., 180.

360 KÖRÖSÉNYI András: Carl Schmitt állam- és politikaelméleti alapfogalmai. In: Politikatudományi Szemle 2000/3-4., pp. 5-24.
} 
önfeladás-szerüen kell, hogy alávesse magát az államnak, míg az állam - végre - megengedheti magának azt a luxust, hogy csak a veszélyre koncentrál. Ez a megfontolás több sebből vérzik. Az állam valóban lazíthat néhány intézményvédelmi kötelezettségének teljesítésén, ugyanakkor a különleges jogrendben hozott valamennyi intézkedés, legyen annak az alapja $a$ priori a különleges jogrend bevezetését megelőzően alkotott szabály, vagy olyan, amelyet azóta alkottak meg, továbbra csak a szükséges mértékben és arányosan alkalmazhat jogkorlátozó intézkedéseket. Továbbá, minden intézkedésnek, célját tekintve, ugyan annak a jogelvnek a keretei között kell maradnia, amely a szokásosnál nagyobb hozzájárulást és alávetettséget vár el az emberektől. Tehát valójában kettős kötelezettségről beszélünk, amely egyszerre terheli különleges jogrendi időszakban az államot és az embereket egyaránt.

A különleges jogrendet meghatározó két tényező, a jogállamiság, mint origó, amelyből indulunk és amelyhez szeretnénk visszatérni, valamint a veszélyhelyzet, amely elmozdít minket a jog által szabályozott boldog gondtalanságból. A két fogalom szoros kapcsolata a különleges jogrend relációjában csak érdekesebbé teszi, hogy míg a jogállamiságról számtalan elmélet és írás született, ${ }^{361}$ addig a veszélyhelyzetet kézzelfogható, természetben tapasztalható jellege miatt nem sokan illetik komolyabb kritikával. ${ }^{362}$ Holott mindhiába minden anyagi és alaki jogi szabály, az alkotmánymag és a jogrendszer többi eleme közötti megkülönböztetés, ha a különleges jogrend bevezetését megalapozó döntés hibás megfontolásokon nyugszik. A különleges jogrend bevezetése joghatását tekintve jogi-politikai döntés lesz, amelynek meghatározó hatása lesz a jogforrásokra, a döntéshozatalra és a politikai viszonyokra egyaránt. A döntéshozatal tehát joghatásán túl legalitását és legitimációját tekintve is jogilag meghatározott, ugyanakkor az a primer információ, amelyre döntését az arra feljogosított alapozza jogilag nem értelmezhető. A primer információ olyan adatokon és szakmai értékelésen alapul, amelyet jogilag nem lehet szabályozni, ugyanis a szakmai sajátosságokkal ellentétes lenne, ha a rugalmas és eleven értékelési szempontokat jogszabályba dermesztve rögzítené a jogalkotó. A veszélyhelyzetet, amíg az elenyésző mértékben, nem meghatározóan jelentkezik, az állam rendes müködési keretei között képes kezelni. A veszélyhelyzet domináns jelenléte már önmagában az állam egyfajta diszfunkcionalitását jelenti, hiszen a vis major események kezelésére is kialakította az állam kompetens szakapparátusát, amely azonban értelemszerüen

\footnotetext{
${ }^{361}$ A teljesség igénye nélkül: SzIGETI-TAKÁCS; CHRONOWSKI Nóra: Jogállamiság - Gondolatok a magyar és az európai uniós jogfejlődésröl. In: Magyar Közigazgatás 2016/4., pp. 32-42.; JAKAB András: A jogállamiság mérése indexek segitségével. In: Pázmány Law Working Papers 2015/12. http://d18wh0wf8v71m4.cloudfront.net/docs/wp/2015/2015-12 Jakab.pdf (letöltés dátuma: 2019. 09. 29.)

${ }^{362}$ HuSSAIN, p. 16.
} 
a rendelkezésre álló emberi, anyagi és jogi eszközökre tekintettel korlátozott. Onnantól kezdve, amikor az állam diszfunkcionalitása meghatározó méreteket ölt, szóba kerülhet a különleges jogrend bevezetése. A diszfunkcionalitás mérhető területi alapon is, amely lehetőséget teremt arra, hogy a szükségesség és az arányosság figyelembevételével a különleges jogrendet is csupán területi korlátozottsággal vezessék be. Ugyanakkor, ha az érintett terület szolgáltatja az egész ország számára a vizet vagy az áramot, rögvest megkérdőjeleződik a területi korlátozottság fenntartásának indokoltsága.

A különleges jogrend mindenképpen más lesz a normális jogrendhez képest, jellegében és eszközeiben egyaránt. Csink Lóránt rámutat, ${ }^{363}$ hogy a fenyegetettség és az alapjog-korlátozás mértéke egyenes arányosan nő, amelyhez általában tudatos és önkéntes jogfosztás társul. Különösen igaz ez, ha különleges jogrend bevezetésére kerül sor. Véleménye szerint a háttérben konkuráló értékek - ti. biztonság és szabadság - egyikét sem abszolutizálhatjuk a másik kárára. Ennek oka nem csak az optimális értékek meghatározásának bizonytalanságán alapul, hanem azon a felismerésen, hogy egyik vagy másik érték teljes mértékü kizárása (stílusosan likvidálása) esetén egyszerüen értelmét veszíti a másik. A biztonság és a szabadság együtt nyer értelmet és valójában nem egymást gyengítik, hanem messzemenőkig erősítik. Végső soron pedig a közöttük fennálló harmónia a jogállam stabilitásának egyik alappillérét jelenti. Ez a harmónia nem jelent ugyanakkor statikusságot. A jogrendszer folyamatos változásában megjelenő ritmika érvényesül a szabadság és a biztonság táncában is, amelyet a terrorizmusra tekintettel definiált különleges jogrendi szabályok tesznek igazán látványossá és aktuálissá. A különleges jogrend bevezetésének klasszikus okai mellé - ti. nemzetközi és nem nemzetközi fegyveres konfliktusok, természeti katasztrófák vagy ipari szerencsétlenségek - társult a nemzetközi terrorizmus is. Ez pedig részben változtatott a különleges jogrend eddigi alkotmányos játékszabályain.

\footnotetext{
${ }^{363}$ CSINK, pp. 7-16.
} 


\subsection{Franciaország 2015-2017 között bevezetett különleges jogrendje és hatásai}

„La liberté sera toujours plu forte que la barbarie [...], le rassemblement de tous, sous toutes

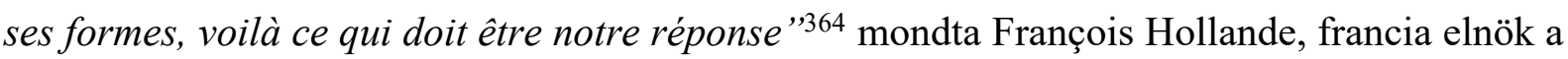
Charlie Hebdo francia szatírikus lapnál 2015. január 7-én elkövetett terrorcselekmény után a nemzetközi sajtónak adott nyilatkozatában. ${ }^{365}$ Egy hét híján 10 hónapon belül Franciaország elszenvedte a második komolyabb terrortámadást is, amely a második világháború óta nem tapasztalt pusztítást végzett. Legtöbben a Bataclan nevü szórakozóhelyen egy koncert alatt elkövetett támadás során vesztették életüket. Franciaország legnagyobb nemzeti ünnepén, július 14-én (le jour de la Bastille) egy terrorista egy kibérelt teherautóval hajtott az ünneplők közé közvetlenül az esti tűzijátékot követően, kihasználva a gyengébb látási-tájékozódási viszonyokat és a tömeg lassú oszlását az eseményt követően.

A nizzai merénylet után nem sokkal végzett felmérés szerint Franciaország felnőtt lakosságának több mint $80 \%$-a kifejezetten valószínủnek tartotta egy újabb komolyabb terrortámadás bekövetkezését 6 hónapon belül. ${ }^{366}$ A franciaországi terrortámadásoknak számos hatása volt, a halálos áldozatok mellett. Többek között közösségi rendezvények maradtak el, amelyek közül a legnagyobb a 2015. évi Fények ünnepe lett volna decemberben, amelyet viszont a párizsi terrortámadásokat követően másnap először elnapoltak, majd két nappal később - arra az évre vonatkozóan - le is mondtak. ${ }^{367}$

Korábban már volt szó az értekezésben arról, hogy milyen politikai, társadalmi és jogi következményekkel jártak a 2010-es évek rendkívül sürü és számos halálos áldozattal járó európai terrortámadásai, amelyek nagyrészt Franciaországra fókuszáltak. Ugyanakkor az alábbiakban részletesen elemzem a terrorveszélyre tekintettel bevezetett francia különleges jogrendet, mert korábban csak közel-keleti országokban volt arra példa, hogy a hatóságok ilyen mértékü nyomás alatt álltak és sokszor úgy tünt, képtelenek gátat szabni az országot fenyegető

\footnotetext{
${ }^{364}$ A szabadság mindig erősebb lesz a barbarizmusnál [...], az, hogy mindannyian összegyültünk, ez kell, hogy legyen a valódi válasz. (saját fordítás)

${ }^{365}$ A vallási szélsőségesek által megtámadott francia lap amúgy hazájában sem fogy kifejezetten meghatározó mértékben, nemzetközi ismertségre igazán pedig csak a terrortámadást követően tett szert. Néhány hónapon keresztül a világ 'Je suis Charlie' lázban égett, míg a párizsi merényletsorozat be nem következett.

${ }^{366}$ GASTON, Sophie: Mapping and responding to the rising culture and politics of fear in the European Union. Nothing to fear but Fear itself? Demos, London. 2017 https://www.demos.co.uk/wpcontent/uploads/2017/02/Demos-Nothing-to-Fear-but-Fear-Itself-Summary.pdf (letöltés dátuma: 2019. 09. 29.), p.138.

${ }^{367}$ Fête des Lumiéres

http://www.fetedeslumieres.lyon.fr/en/news/au-sujet-de-la-programmation-2016 (letöltés dátuma: 2019. 09. 29.)
} 
terrornak. A 2001. szeptember 11-én elkövetett new yorki terrortámadást az új típusúí36 terrorizmus antréjának szokták nevezni. Franciaország 2012-2017 közötti időszaka viszont abból a szempontból egyedülálló, hogy figyelemmel kísérhettük, a jogállami intézmények miként veszik fel a harcot az államra leselkedő közvetlen veszéllyel. Mivel európai vagy más nyugati országban erre - a háború esetét kivéve - még nem volt példa, a kutatás kitüzött céljainak eléréséhez szükségszerü volt az említett időszak részletesebb, elemző vizsgálata.

${ }^{368}$ TÁLAS 2006, p. 5. 


\subsubsection{Különleges jogrend a francia jogrendszerben}

Az 1958-as francia alkotmány alapvetően két típusát ismeri a különleges jogrendnek. Az alkotmány 16. cikke (pouvoirs exceptionnels) arra az esetre, ha az ország területi integritása vagy függetlensége kerülne veszélybe, felhatalmazza az elnököt a legfóbb hatalommal. Ugyanakkor már az alkotmány kimondja ennek a kivételes hatalomgyakorlásnak a relatív jellegét, amelyet tárgyában és idejében is keretek közé helyez. Az alkotmány 36. cikke (etat de siége) alapvetően a külső támadásokra összpontosít, s ennek megfelelően a veszélyek elhárítását nem a civil igazgatásra terheli, hanem ezzel a katonai igazgatást bízza meg. Franciaországban létezik egy harmadik különleges jogrendi típus is, amely viszont több szempontból is kilóg a sorból. Egyrészt, nem az alkotmány szabályozza, hanem egy törvény (Loi n. 55-385 du 3 avril 1955 relative à l'état d'urgence), másrészt egy kicsit vegyíti az alkotmányban már szabályozott két esetet. Az elnök kivételes és kizárólagos hatalomgyakorlását például kizárja azzal, hogy a kormány lemondását és a parlament feloszlatását követően legkésőbb 15 napon belül megszünik a különleges jogrendi állapot a törvény erejénél fogva. ${ }^{369} \mathrm{Az}$ état d'urgance szerinti jogrendet az algériai háború idején fogadták el, méghozzá kifejezetten arra a célra, hogy azt a konkrét konfliktust képes legyen kezelni a francia állam. Abból a szempontból valóban indokoltnak tünik a két különleges jogrendi kategória egyes elemeinek vegyítése, hogy a konfliktus belső és külső jegyeket egyaránt mutat. Egyrészt, ez egy belpolitikai kérdés volt, amelyet az észak-afrikai franciatudatú lakosság (pieds-noirs) ${ }^{370}$ és a gyarmatok helyzetének politikai-közjogi rendezése indokolt. Másrészt, Franciaország a területi integritására hivatkozott a nemzetközi közösség előtt, amikor fegyveresen lépett fel az algériai harcosokkal szemben. A konfliktus kezelésének nemzetközi megítélése pedig finoman szólva is eléggé megosztott volt. ${ }^{371372}$ A francia elnök 2015. november 16-án - 3 nappal a Bataclan és számos párizsi célpont elleni merényletet követően - a francia parlament két házának összevont ülésén Versailles-ban bejelentette az alkotmány két tárgyban tervezett módosítását. Az egyik a már bevezetett különleges jogrend

\footnotetext{
369 Törvény 4. cikke.

370 Olyan - többségében francia származású - európaiakat jelöl a kifejezés, akik a 19-20. század során ÉszakAfrikában születtek. Jelentése: feketelábú.

${ }^{371}$ Az Egyesült Államok nem fogadta el Franciaország kezdeményezését a NATO 5. cikkelyének az algériai konfliktus kezelésére való alkalmazhatóságát illetően, ahogyan az összes többi volt gyarmat esetében is hasonlóan járt el. Az 5. cikkely második bekezdése erre hivatkozással került bele később a Washingtoni Egyezménybe, amely gyakorlatilag kizárta az egykori gyarmatokon a NATO erők bevetését. Így minden gyarmat és tengerentúli terület az adott ország kizárólagos belügyében maradt.

372 Vö. SÁGVÁRI Ádám: Különleges jogrend a francia jogban. Az állandósult kivételesség. In: Iustum Aequum Salutare 2017/4., pp. 179-188.
} 
alkotmányos kereteinek újra szabását, vagyis a kivételes jogkörök bővítését és az alkalmazásukkal azonos időben érvényesülő kontroll mechanizmusok gyengítését, míg a másik az állampolgársági jogviszony megszüntetésére irányuló szabályok könnyítését célozta. ${ }^{373} \mathrm{Az}$ alkotmánymódosítási kezdeményezés nem ment végül át a parlamenten, de Franciaország 2017-ig tartó vitatható politikai és közjogi jellegzetességei sem feltétlenül nevezhetők sikertörténetnek. Már csak azért sem, mert a kormány indokolása szerint a biztonság garantálása érdekében volt szükség a különleges jogrend folyamatos fenntartására, ugyanakkor több, halálos áldozattal járó terrorcselekményt is elkövettek ezen időszak alatt. Köztük a legtöbb áldozattal a 2016-os nizzai gázolásos terrorcselekmény.

373 Olivier, Duhamel: Terrorism and Constitutional Amendment in France. In: European Constitutional Law Review 2016/1., pp. 1-5. 


\subsubsection{A 2017. október 30-án elfogadott 2017-1510. számú törvény}

Számos probléma vetődött fel a 2015. november 13-át követően bevezetett és 2017. november 1-jén megszüntetett état d'urgence kapcsán, amely közel két teljes évig volt hatályban. Franciaország erre az időszakra az Emberi Jogok Európai Egyezményének alkalmazását is felfüggesztette. ${ }^{374}$ A törvény 2 . cikke kimondja, hogy a 12 napot meghaladó időtartamot csak törvény rendelheti el, amelynek - az érvényesség feltételeként - tartalmaznia kell egy konkrét határidőt a különleges jogrend megszünéseként. A kormány előterjesztése alapján a francia parlament összesen 6 alkalommal hosszabbította meg a különleges jogrend hatályban tartását ez alatt az időszak alatt.

A 2015-ös párizsi terrortámadás óta fennálló különleges jogrendet 2017. november 1-jén éjfélkor megszüntették, ${ }^{375}$ felváltására a francia parlament elfogadta a 2017-1510 számú törvényt. A különleges jogrend megszüntetésére már korábban is tettek kísérletet, de ezt a 2016os nizzai terrortámadás meghiúsította, és a későbbiekben még három alkalommal szavazta meg a francia parlament a különleges jogrend meghosszabbítását. ${ }^{376}$ A jogszabály célja, hogy a soha nem látott mértékü veszélyre, és az ezzel párhuzamosan jelentkező és egyre növekvő biztonság iránti vágyra tekintettel a jogalkotó megfelelő eszközöket biztosítson a közigazgatási szervek számára, amellyel megerősíthetik a belső biztonságot és hatékonyan vehetik fel a küzdelmet a terrorizmussal szemben. ${ }^{377}$ Nem ez volt az első törvény a sorban, amelyet a francia parlament a terrorizmus veszélyére tekintettel fogadott el, hiszen francia alkotmányjogászok egy csoportja már 2017 nyarán felhívta a társadalom és a politikusok figyelmét arra, hogy a terrorizmusra tekintettel megalkotott jogszabályok észrevétlenül hálózzák be a francia jogrendszert és kihatnak az egyén és a társadalom életének minden szegletére. ${ }^{378}$ A jogszabály megalkotásával

\footnotetext{
374 https://www.coe.int/en/web/secretary-general/home/-/asset publisher/oURUJmJo9jX9/content/franceinforms-secretary-general-of-article-15-derogation-of-the-european-convention-on-human-rights $\quad$ (letöltés dátuma: 2019. 09. 29.)

${ }^{375}$ Az igazsághoz hozzátartozik, hogy a különleges jogrend 2017. november 1-jén még hatályban volt, miközben a 2017. október 30-án elfogadott 2017-1510 számú törvény már 2017. október 31-én hatályba is lépett. Vagyis a különleges jogrendet felváltó rendes jogrendi speciális új szabályozás és a különleges jogrend, amelynek felváltásra alkották meg párhuzamosan volt hatályban egy teljes napig. Ez arra enged következtetni, hogy a különleges jogrend kivételes rendelkezései és a rendes jogrend védelmi jellegü szabályozása közül, a 2017-1510 számú törvény inkább a különleges jogrendi kivételességhez közelít jobban, semmint a rendes jogrendben megszokott szabályokhoz.

${ }^{376}$ Elsőként a 2016. július 21-én elfogadott 2016-987 sz. törvény, később a 2016. december 19-én elfogadott 20161767 számú törvény, végül pedig a 2017. július 11-én elfogadott 2017-1154 számú törvény.

377 2017-1510 számú törvény.

$378 \mathrm{https}: / /$ www.cncdh.fr/sites/default/files/170706 avis sur le pil securite interieure terrorisme.pdf 3. oldal, https://www.dalloz-actualite.fr/chronique/projet-de-loi-renforcant-lutte-contre-terrorisme-et-securite-interieureduplicite-du-presi\#.XFl1uS35fdc (letöltés dátuma: 2019. 09. 29.)
} 
a parlament az 1955. április 3-án elfogadott 55-383 számú törvény további alkalmazását akarta elkerülni. A kivételességet a jogszabály - természetesen csak a terrorizmus viszonylatában átülteti a rendes jogrendbe.

A 2017. október 30-án elfogadott jogszabály logikája, hogy az 1955. április 3-án elfogadott 55385 számú törvény kivételes rendelkezéseit átültesse a rendes jogba. Ez a logika azért meglepő, mert így a különleges jogrend úgy ér véget, hogy az abban megjelenő kivételesség - ugyan a terrorellenességre korlátozva, de mégis - tovább él a rendes jogrendben. A különleges jogrend kivételessége nem szünt meg, hanem egyszerüen elveszítette kivételes jellegét. A jogalkotói lépést, és a mögötte meghúzódó jogpolitikát sokan bírálták: többek között helyhatóságok, egyesületek, szervezetek és közösségek a jogállamiság megfertőzésének nevezték a lépést, ${ }^{379}$ mások méregnek nevezték. ${ }^{380}$

A 2017. október 30-án elfogadott törvény a belbiztonsági törvénybe 4 új elemet emelt át a korábban meglévő különleges jogrendből: 1) védelmi határok kialakítása, 2) vallásgyakorlás helyszínének bezárása, 3) individuális intézkedések, mint a közúti ellenőrzés és a leghallgatás és 4) házkutatás és hatósági lefoglalás. Ugyanakkor a törvény nem csak az 1955-ös jogszabályból merített, hanem a büntetőtörvénykönyvet is módosította. Egyebek mellett ${ }^{381}$ például az olyan új büntetőjogi tényállás megteremtésével, amelyet a szülői ösztönzésre elkövetett terrorcselekmény ${ }^{382}$ névvel illetnek, amely a fiatalkorú terrorista csoportban való közremüködésével kapcsolatos szülői felelősséget mérlegeli. ${ }^{383}$

A törvény módosítja továbbá a büntetőeljárásról szóló törvényt is, azzal, hogy a közúti ellenőrzések idejét kiterjeszti, arra hivatkozva, hogy az időtartam meghosszabbításával a határokon átívelő bünözés megelőzése érdekében tett erőfeszítések hatékonyságát növelnék. A büntetőeljárási törvény 78-2 cikke így már lehetővé teszi, hogy vasútállomások és kikötők kiterjesztő értelemben véve - környezetében is ellenőrzéseket folytathassanak. Ebbe beleérti a

379 A különleges jogrend megfertözi a rendes jogrendet. Sydicat de la Magistrature 2017 június 8 http://www.syndicat-magistrature.org/L-etat-d-urgence-contamine-le.html (letöltés dátuma: 2019. 09. 29.)

${ }^{380}$ Defender of Rights (J, TouBON, le Monde, 2017. június 23, míg az ember jogvédő szervezet elnöke (CNCDH) mint kiegészítést a különleges jogrendi szabályokhoz tekint, valamint a különleges jogrendi szabályok átszivárgását a rendes jogrendbe (C. LAZEGERS, Press Conference, 25 September 2017)

381 Valamennyi javaslatról ld. J-B., THIERRY: Actualité du droit criminel 2017 http://sinelege.hypotheses.org.bases-doc.univ-lorraine.fr (letöltés dátuma: 2019. 09. 29.)

382 A kifejezést először Y. Mayaud használta L'évolution du droit pénal général című előadásában, amelyet 2017. november 7én tartott Aix-en-Provenceban.

${ }^{383}$ Büntető törvénykönyv 421-2-4-1 cikkét módosította a 2017. október 30-án elfogadott 2017-1510 számú törvény 10. cikke 
jogszabály a közönség számára nem hozzáférhető (nyilvános) helyiségeket is, továbbá kikötők és repülőterek 10 km-es környezetében határellenőrzéseket vezethetnek be, mi több, mindezek időtartamát legfeljebb 6 óráról, legfeljebb 12 órára növelte. ${ }^{384}$ Ezen túlmenően a parlamenti képviselők indítványozták, hogy a terrorizmussal gyanúsított személyek esetében az előzetes fogvatartás időtartama 72 óráról 30 napra növekedjen, ${ }^{385}$ de ezt a parlamenti többség végül elutasította. A módosítások felsorolása nem teljes körü, ugyanakkor a változtatások bírálóinak ezek a módosítások voltak a legerősebben kritizált elemei. Arra hivatkoztak, hogy ezek a módosítások egytől-egyig tisztán különleges jogrendi természetűek. Így a rendes jogrendi szabályok közötti helyük és szerepük erősen vitatható és megkérdőjelezhető.

Ezek az intézkedések egytől-egyig az 1955-ös törvényből kerültek a rendes jogrendbe, ezért fennáll a veszélye, hogy alkalmazásuk jogsértő lesz, mivel jelentős mértékben érintik az alapvető jogokat és szabadságokat. Ennek a veszélynek az alapja, hogy a jogszabályban keverednek a hatósági jogalkalmazásra és a bírói hatáskörökre vonatkozó szabályok. Mindezt úgy éri el a jogalkotó, hogy erösítette a hatósági jogköröket a bírói hatáskörök kárára. Erre máshogy nem is nagyon kerülhetett volna sor, hiszen a hatósági joggyakorlás feletti törvényességi kontrollt a bíróság gyakorolja, amely nélkül a hatósági jogalkalmazás kevesebb korláttal, szabadabban müködhet. A jogalkotói magyarázat szerint mindez csupán a biztonsághoz elengedhetetlen jogszabályi feltételekről szól, míg bírálói szerint a biztonság és a szabadságjogok párhuzamos garantálása közötti érzékeny egyensúly felborulásához vezet. ${ }^{386}$ Ezt az integrációt sokan bírálták, és a jogrendszer stabilitását súlyosan veszélyeztető felfordulásnak minősítették, mondván: így Franciaország a felelösség társadalma helyébe a gyanakvás társadalma lépett. ${ }^{387}$ Végső soron pedig a hatósági jogalkalmazás egyre kevésbé tartozik a jogállami korlátok alá, különösen, azon intézkedések vonatkozásában, amelyek közvetlenül érintik az alapvető jogokat és szabadságokat.

\footnotetext{
${ }^{384}$ Büntető eljárási kódex 78-2 cikke, amely összhangban áll a 2016. március 9-én megalkotott, a schengeni határokról szóló 2016/399 EU rendelet 23. cikkével.

${ }^{385}$ A 2017. szeptember 21-én benyújtott 516. számú módosítási javaslat, melyet Olivier Marleix és Guillaume Larrivé jegyeznek.

${ }^{386}$ Lásd az alapjogi biztos 2017. július 7-én közzétett 17-05 számú véleményét. „Annak érdekében, hogy a rendes jogrendszer részévé váljanak a terrorizmus elleni küzdelem azon rendelkezései, amelyek eddig a különleges jogrend részét képezték, a kormány magas fokú kockázatot vállal azzal, hogy veszélyezteti a büntetőjog és a jogok és szabadságok közötti érzékeny egyensúlyt.” https://juridique.defenseurdesdroits.fr/doc num.php?explnum $\mathrm{id}=16676$ (letöltés dátuma: 2019. 09. 29.)

${ }^{387}$ M., Delmas-MARTY, De l'état d'urgence au despotisme doux. In: Libération, 16 july 2017.
} 
Az új rendelkezések rendes jogrendben érvényesülő (civil) közigazgatás számára teljesen új elemeket emel át, amelyekkel az országban müködő nemzetközi terrorizmus elleni fellépés hatékonyságát növeli a jogalkotó. Azonban a rendes jogrendbe való átemelésükkel ezek a kivételes rendelkezések elveszítették kivételes jellegüket, továbbá nem egyszerűen a korábban meglévő biztonsági szabályok helyébe léptek, hanem egyúttal a mellette megmaradó (párhuzamosan érvényesülö) biztonsági jellegü szabályokat elhalványítják, és így a jogalkalmazó által végezhető jogértelmezés számára mindenképpen lerontják, hiszen az ebben megfogalmazott elvek lesznek az irányadók a továbbiakban. Egyfajta iránytüként szolgálnak a jogalkalmazás számára.

Az egyik legfontosabb új eszköz, a szabad mozgáshoz való jogot korlátozza azzal, hogy meghatároz egy ún. biztonsági zónát. Ennek a pontos paramétereit a megyék élén álló prefektus, illetve Párizsban a rendőrség vezetője jelöli ki határozatban. A határozatban egyúttal kijelölik a zónába való be- és kilépés módját, az áthaladás lehetőségét és a zónán belüli mozgás módját (közlekedési folyosók kijelölésével). Ennek az intézkedésnek a célja, hogy valamilyen meghatározott helyszínt, épületet, eseményt kiemelt védelemmel lássanak el a hatóságok. A kijelölésnél az a meghatározó, hogy a lehetséges helyszínek közül, melyekhez kapcsolódik jelentősebb terrorveszély, illetve mérlegelik a rendezvény vagy a helyszín sebezhetőségét, befogadóképességét és kiemelt politikai vagy kulturális jellegét.

A biztonsági zóna határainak kijelölésekor „a vonal területi és időbeli hatálya szükséges és arányos kell, hogy legyen a veszéllyel” és „a zónán belüli mozgás szabályainak meghatározásakor különös figyelemmel kell lenni az érintettek magán-, szakmai és családi életére." ${ }^{388}$ Ezek a rendelkezések a gyakorlatban nem biztos, hogy maradéktalanul megfeleltethető az Emberi Jogok Európai Bírósága által megfogalmazott alapelveknek. ${ }^{389}$ Ugyanakkor látszólag a rendelkezések az elvárt eljárási követelményeket tükrözik: az érintettel azonos nemű végezheti csak a ruházat és a csomagok átvizsgálását, ${ }^{390}$ továbbá kizárólag a gépjármü vezetőjének előzetes hozzájárulásával végezhetik el a gépjármü átvizsgálását. ${ }^{391} \mathrm{~A}$ lezárások időbeli hatályát a jogalkotó maximálta, időtartama nem lehet hosszabb 6 hónapnál,

\footnotetext{
388 Törvény 226-1 cikke.

389 Gillan and Quinton v. UK, 4158/05 (ECHR), amelyben a bíróság elítélte a nyomozóhatóságok terrorfelderítéssel összefüggésben kialakított és szerintük túlzóan diszkrecionális jogköreit.

${ }^{390}$ A törvény 226-1 cikke biztosítja, hogy a motozást és a ruházat átvizsgálását a rendőrség ugyanolyan nemü tagja végezze el.

391 Törvény 226-1-6 cikke.
} 
illetve a lezárást elrendelő hatósági határozatot minden esetben indokolni kell, meghozatalára pedig egy kontradiktórius eljárás keretei között van csupán lehetőség. ${ }^{392}$ Hiába az eljárási garanciák, amelyek látszólag megnyugtatóan követik a korábban már alkalmazott és kipróbált ellenőrzési gyakorlatot (pl. repterek, kiemelt állami rendezvények vagy sportesemények vonatkozásában), az ilyen jellegű rezsimszabályok egy látens veszélyt hordoznak magukban. Ez pedig az időbeli hatály normatív korlátozottsága ellenére is a folyamatosan érvényesülő ellenőrzésekkel óhatatlanul együtt járó automatizmusban rejlik. Hiszen, a biztonsági földrajzi meghatározottságából adódik, hogy jogkorlátozás alapvetően egy adott közösséget fog érinteni, amely rendszerint homogén társadalmi réteget képez, ${ }^{393}$ valamint többnyire azonos valláshoz tartozik. ${ }^{394}$ A biztonsági zóna hatása ráadásul nem kizárólagosan csak a biztonsági zóna határán belül élőket érinti, hanem azokat is, akiknek az otthonuk és a munkahelyük közötti korábban használt legrövidebb útvonal a biztonsági zónán keresztül vezet. Vagyis, a lakosságnak lehetősége van választani a megnövekedett útiköltséget és utazással töltött időt is jelentő hosszabb, elkerülő útvonal, valamint a legalább napi kétszeri biztonsági ellenőrzéssel járó biztonsági zónán való áthaladás között. A szabályozással kapcsolatos bizonytalanságunkat és rossz érzésünket az sem enyhíti, hogy ezek a rendelkezések súlyosan érintik az oktatási-nevelési intézménybe tartó gyermekek és a szociális vagy egészségügyi intézménybe tartó idősek és betegek életét is, ha lakhelyük és úticéljuk között egyszer csak létrejött egy biztonsági zóna.

A biztonsági zóna kijelölésekor nem szükségszerü, hogy a hatóság tekintettel legyen a fennálló területi és helyi közigazgatási határokra. Vagyis, a biztonsági zóna 6 hónapra akár létrehozhat egy sajátos közösséget is, amelynek létrejöttét és igazgatási-szervezési alapját a biztonsági rendszabályok adják. Ebben az esetben ráadásul az ellenőrzésekhez társuló automatizmus miatt a lakosság valóságosabbnak fogja érezni új biztonsági-helyhatóságát, mint a helyi önkormányzatát. Az újonnan alakult ad hoc közösség további sajátossága, hogy a bevándorló kisebbségek által sürün lakott negyedekben jönnek létre, hiszen a terroristák rendszerint ezeket az etnikai és vallási szempontból homogén lakónegyedeket részestik előnyben, mivel itt könnyebben elvegyülhetnek és láthatatlanná válnak a hatóságok számára. Mindez pedig a társadalom meglévő strukturáltságát betonozza be. A biztonsági zóna lakói (mi) úgy érezhetik,

\footnotetext{
392 Törvény 227-1-2 cikke.

${ }^{393}$ A kérdés más megközelítésével is hasonló eredményre jutott J., LEBLOIS-HAPPE, O., CAHN, Nouveau projet de loi antiterroriste: attention danger!, amely a 2017. május 22-én elkövetett, manchesteri koncert után elkövetett robbantást hozza példaként.

${ }^{394}$ A törvény 227-1-2 cikke alapján a zár alá vétel arányos kell, hogy legyen a körülményekkel, amelyek alapján azt elrendelték, de nem lehet hosszabb 6 hónapnál, a zár alá vételt egy kontradiktórius eljárás követi, amelyben indokolt határozat születik.
} 
hogy a zónán kívüliek (ők) kirekesztették őket és elfelejtkeztek róluk. A biztonsági zóna lakói között a sorsközösség érzése és kölcsönös szimpátia alakul ki, amely akár egyfajta véd- és dacszövetség formájában éppen ellentétes hatást fog elérni a hatóság eredeti szándékával. ${ }^{395}$

A teljes lakókörzetekre létrehozott biztonsági zónák mellett van lehetősége a hatóságnak a vallásgyakorlás színhelyét is lezárni vagy a hozzáférést (be- és kimenetel) korlátozni. Erre akkor kerülhet sor, ha a vallásgyakorlás színhelyén olyan véleményeket fogalmaznak meg vagy ideológiát terjesztenek, illetve olyan tevékenység folyik, amely diszkriminációt hirdet, gyűlöletet szít, vagy erőszakos cselekmény elkövetésére buzdít. E helyütt célszerü párhuzamot vonni az 1955-ös különleges jogrendi szabályozás és a 2017-es törvény között. Ugyanis, a különleges jogrendi szabályok egyes helyszínek lezárására vonatkozó szabályai a vallásgyakorlás helyszíne mellett kiterjedtek egyéb más helyszínekre is, pl. a színházakra és szórakozóhelyekre. ${ }^{396}$ A közös ezekben nyilvánvalóan a nagy befogadóképesség, amely egyszerre alapozza meg, hogy a helyszín célpont vagy búvóhely legyen, illetve a radikális elemek találkozási esetleg toborzási-beszervezési helyként funkcionáljon. Nem feltétlenül lenne - biztonsági szempontból - indokolt ezt a felsorolást csupán a vallásgyakorlás helyszínére korlátozni. Ezért akár jogos is lehet az észrevétel, hogy a jogszabály diszkriminál egy vallás (iszlám) és egy meghatározott társadalmi réteggel (észak-afrikai származású, kevésbé tehetős bevándorlók) szemben. MICAS névvel illetik azon hatósági ellenőrzéseket és különösen a lehallgatást és a megfigyelést, amelyeket a törvény 228-1 és a törvénnyel módosított belbiztonsági törvény határoz meg. Valamennyi intézkedés csak abban az esetben alkalmazható, ha az konkrét terrorcselekmény elkövetését akadályozza meg, illetve amennyiben az érintett megalapozottan gyanúsítható azzal, hogy magatartása jelentős veszélyt jelent a társadalomra vagy a közrendre nézve, így különösen, ha terrorcsoporthoz való kötődésük kimutatható vagy általában a radikalizáció jeleit mutatják. ${ }^{397}$ A szabályozás a háziőrizet helyett a lakhelyelhagyási tilalmat részesíti előnyben.

\footnotetext{
395 A hatósági határozat indokolása értelemszerủen nem irányulhat arra, hogy az állam egy közösséget szociális jellege, tipikusan kisebbségi mivolta, vagy vallása miatt vonjon szoros ellenőrzés alá. Éppen ellenkezőleg, valamennyi biztonsági intézkedés a veszélyforrások kiszürésére és megszüntetésére irányulhat csak, amely a közösség érdekével szükségszerüen egybe fog esni és kizárólag az állam védelmi kötelezettségének részeként valósulhat meg.

${ }^{396} \mathrm{Az}$ 1955. április 3-án elfogadott 55-385 számú törvény 8. cikke alapján.

${ }^{397}$ A törvény 228-1 cikke arra a személyre utal, akinek a viselkedése veszélyt jelent, mert rendszeresen kapcsolatot tart fenn olyan személyekkel vagy szervezetekkel, amelyek ösztönöznek, részt vesznek vagy támogatnak terrorista tevékenységet (...) vagy elkövetett terrorcselekményt pozitív színben feltüntetve terjesztik.
} 
A jogszabály 228-2 cikke alapján a belügyminiszter elöírhatja, hogy a korlátozással érintett személy valóban ne hagyhassa el a hatóság által határozatban kijelölt területet, amely viszont nem lehet kisebb a nyilvántartásban lakóhelyként megjelölt településnél. ${ }^{398}$ Továbbá lehetősége van a hatóságnak arra, hogy egy viszonylag széles spektrumon előírja az érintett számára, hogy a hatóságnál (jellemzően rendőrségen) meghatározott rendszerességgel jelentkezzen, amely azonban gyakoriságát tekintve nem haladhatja meg a legfeljebb naponta egy alkalmat. ${ }^{399}$ Végül előírhatja a hatóság, hogy az érintett a határozat kiadásától számítva valamennyi későbbi lakóhelyváltoztatással együtt járó lakcímváltozást bejelentsen a hatóság számára. A jogszabály 228-3 cikke lehetőséget teremt arra, hogy az érintett legfeljebb napi egyszeri hatóságnál történő bejelentkezését kiválthatja egy automatizált elektronikus megfigyelési rendszer. ${ }^{400}$ A személyre szóló korlátozások legfeljebb 3 hónapra alkalmazhatók, egyszer 3 hónappal meghosszabbítva. Azonban összesen 6 hónap múltán csak abban az esetben alkalmazhatók újra, ha valamilyen új vagy kiegészítő információ alapozza ezt meg. Összességében azonban így sem haladhatja meg a 12 hónapot az intézkedés hatálya.

A korlátozások közé tartozik, hogy a belügyminiszter ugyanezen érintetteknek indokolt határozatban megtilthatja a kapcsolattartást bizonyos személyekkel, akikkel terrorcsoportban müködtek együtt vagy az érintett radikalizációjában közrehatott. Az intézkedés határideje hasonlóan alakul, mint a tartózkodási hely megváltoztatására vonatkozó szabályok esetében: 3 hónap, amely egyszer meghosszabbítható 3 hónappal, a továbbiakban azonban csak új információ esetében hosszabbítható meg, a 12 hónapot azonban összességében sem haladhatja meg. ${ }^{401}$ Bár úgy tủnhet, hogy ezek az új intézkedések jelentős mértékben sértik az érintettek és közvetlenül mások - alapvető jogait, a törvény elfogadását megelőző parlamenti vita számottevő mértékben enyhített az eredeti elképzeléseken. ${ }^{402}$ Az egyik legszembetűnőbb jogkorlátozás az lett volna, hogy az érintettnek le kellett volna adnia valamennyi elérhetőségét

\footnotetext{
398 A törvény 228-2-1 cikke célja így végső soron annak biztosítása, hogy a családi és szükebb közösségi élet folytatásán túl, a tanulási- és munka-kötelezettségekre is legyen lehetősége az érintettnek.

${ }^{399}$ A francia Szenátus ezt eredetileg hetente legfeljebb három alkalomra maximálta volna.

${ }^{400}$ A törvény 228-4 cikke alapján ehhez szükséges, hogy az érintett - a tényleges tartózkodási hely bejelentésén túl - minden szokásos, eshetőleges, de ismert útvonalat, úticélt, és ideiglenes tartózkodási helyet elöre bejelentsen a hatóságoknak. Viszont az elektronikus megfigyelésre kizárólag a lakóhelyként megjelölt település határán kívül van lehetőség, azon belül csak arról tájékoztathat a készülék, hogy az érintett a település közigazgatási határán belül tartózkodik. Az intézkedés legfeljebb 6 hónapig rendelhető el, amely egy alkalommal megújítható további legfeljebb 6 hónappal, de összességében nem haladhatja meg a 12 hónapot.

401 A törvény 228-5 cikke alapján az intézkedés legfeljebb 6 hónapig rendelhető el, amely egy alkalommal megújítható további legfeljebb 6 hónappal, de összességében nem haladhatja meg a 12 hónapot.

${ }^{402}$ A Szenátus elsőre elutasította, majd a Nemzetgyülés mégis elfogadta (iratszám: 19, 2017. október 3.) viszont a parlament két házának közös ülése mégis elutasította (iratszám: 17, 2017. október 10.).
} 
és a kommunikáció során alkalmazott elektronikus azonosítóját. A klasszikusnak számító telefonszámok és e-mail címek mellett ez különösen a közösségi médiában használt egyedi azonosítókat és az internetalapú kommunikáció sajátos módjait érintette volna.

Az elrendelhető intézkedések mértéke láttán azt gondolhatnánk, ${ }^{403}$ hogy bevezetésükhöz bírói engedély szükséges, azonban a belügyminiszter csupán közli a döntését a jogszabályban kijelölt ügyésszel, ${ }^{404}$ illetve a döntés későbbi megtámadására ennek megfelelően az elsőfokú közigazgatási bíróságnál van lehetőség és megtámadni is ennek megfelelően a közigazgatási bíróságnál lehet. 405

A belbiztonsági törvénykönyv 2017.október 30-án elfogadott módosítása további lehetőségként határozza meg a házkutatást, adathordozók lefoglalását és a rajtuk tárolt adatok rögzítését. Mindehhez az ügyész egyetértésére van szükség. A Juge des libertés et de la détention fogja megadni az engedélyt, amely a Tribunal de grande instance de Paris része. Az engedély kiadására akkor biztosít lehetőséget a törvény, ha az eljárás alá vont személy fokozottan/megalapozottan gyanúsítható azzal, hogy terrorcsoport tevékenységében vesz részt vagy a radikalizáció jelei észlelhetők rajta. ${ }^{406}$ A házkutatást csak a tulajdonos vagy a bérlő jelenlétében, és csak reggel 6 óra és este 9 óra között lehet végrehajtani, valamint a bíró indokolással ellátott határozata alapján, a házkutatás végrehajtásának idejére átmenetileg, őrizetbe lehet venni. ${ }^{407} \mathrm{Az}$ érintettnek lehetősége van arra, hogy a házkutatás foganatosítása idejére jogi képviselőjének jelenléthez ragaszkodjon, ez ugyanakkor nem akadályozhatja a házkutatást. ${ }^{408} \mathrm{~A}$ házkutatás során elektronikai eszközöket is ellenőrizhetnek és az azokon tárolt adatokról másolatokat készíthetnek és tárolhatják. ${ }^{409} \mathrm{Ez}$ az egyetlen olyan eszköz, amelyet bíró előzetes engedélyéhez köt a jogszabály. ${ }^{410}$

\footnotetext{
${ }^{403}$ A büntetőeljárási kódex 138. cikkének 1-3-5-9 bekezdései.

${ }^{404}$ A területileg illetékes ügyészt egyszerüen értesítik.

${ }^{405}$ A törvény 228-2 cikke az érintett a hatósági döntés közlésétől számított 1 hónapon belül, vagy az intézkedés meghosszabbításáról szóló döntés közlésétôl számított 1 hónapon belül a közigazgatási bírósághoz fordulhat jogorvoslatért. A bíróságnak 2 hónapon belül kell döntést hoznia. A fellebbezés nem érinti a törvény 521-1 cikke és az 521-2 cikke alapján fennálló törvényi vélelmet.

${ }^{406}$ A törvény 229-1 cikke arra is kiterjed a hatálya, akinek a magatartása annak a veszélyével jár, hogy a szülői ösztönzésre elkövetett terrorcselekmény tényállását merítheti ki.

407 Törvény 229-4 cikke.

408 Törvény 229-1-4 és 229-2-3 cikkei.

${ }^{409}$ Törvény 229-5 cikke.

${ }^{410}$ Ez további jogorvoslatra ad lehetőséget: törvény 229-3 cikke lehetővé teszi, hogy az érintett 15 napon belül a Párizsi Fellebviteli Bírósághoz forduljon, amelynek lehetősége van további hatósági intézkedésekkel kapcsolatos panaszok meghallgatására (229-3 cikk).
} 
A különleges jogrendben bevezethető átmeneti intézkedések akkor alkalmazhatók, ha a közrendet súlyos és közvetlen veszély fenyegeti, valamint olyan események idején, amelyek természetükben vagy súlyosságukból fakadóan szerencsétlenséget hozhatnak. ${ }^{411}$ Ezzel szemben a 2017-ben bevezetett 4 intézkedés alkalmazásának lehetősége a bekövetkezett terrorcselekményhez, illetve a súlyos és közvetlen terrorveszélyhez kötődik. A 2017-es jogszabály ezért a természetes személyek védelmét hivatkozza meg céljai között. Az $\mathrm{NCCHR}^{412}$ véleményében figyelmeztet, hogy visszaélésekre adhat okot, ha a védelmi zónákat ténylegesen alkalmazzák a jogszabályi meghatározottság szofisztikáltabbá tétele nélkül, mert 1) a védelmi zóna fogalma, valamint a 2) a veszélynek kitettség pontatlanul van meghatározva, és összevetve 3) a terrorizmus fogalmának konkrétságával lehetőséget teremt arra, hogy a hatóság önkényesen alkalmazza a jogot. ${ }^{413}$

A Velencei Bizottság a jogszabály első parlamenti tárgyalásakor 2016-ban elmondta véleményét, amelyben többek között azt kifogásolta, hogy a terrorveszély egy nagyon nehezen definiálható jogi feltétel, amelynek a fennálltát nem lehet kétséget kizáróan igazolni. A testület utalt arra, hogy a nyugati államok gyakorlatilag folyamatosan terrorveszélynek vannak kitéve. Javasolta továbbá, hogy a terrorveszéllyel összefüggésben bevezetett különleges - és egyébként átmenetinek szánt - intézkedéseket minősített parlamenti többség előzetes egyetértéséhez kössék. ${ }^{414}$ Az ET emberi jogokért felelős biztosa megkérdezte a Szenátust a 2017-es változásokkal összefüggésben. Megállapította, hogy erős a gyanú a hatóság diszkrecionális döntésének gyakorlatban érvényesülő kizárólagosságára, mert a terrorizmus veszélyének, mint fogalomnak nincs jogszabályban (vagy akárcsak a joggyakorlatból kikövetkeztethető) pontos fogalma. Mindeközben a közigazgatási bíró törvényességi ellenőrzése kizárólag a posteriori érvényesülhet. ${ }^{415}$

Összevetve a különleges jogrendi szabályozást 1955-ből és a 2017-es szabályozást ${ }^{416}$ szembetünik, hogy a jogalkotó eltérően szabályozza a védett jogtárgyat. Különleges jogrendben bűncselekményt követ el, aki bármilyen módon gátolja, akadályozza vagy meghiúsítja a

\footnotetext{
${ }^{411} \mathrm{Az}$ 1955. április 3-án kelt 55-385 számú törvény 1. cikk

412 National Consultative Commission on Human Rights.

${ }^{413} \mathrm{CNCDH}$, a belbiztonság megerősítéséről és a terrorizmus elleni harcról szóló törvénytervezetről készített vélemény 2017. július 6., p. 8 .

${ }^{414}$ A Velencei Bizottságnak a Nemzet védelméről szóló francia törvénytervezetre adott véleménye. 838/2016. sz. vélemény. 2016. március 11-12.

${ }^{415}$ N. Muiznieks, a francia Szenátusnak küldött levél, July 10 2017, CommHR / NM / sf 029-2017

416 Törvény 228-1 cikke.
} 
hatóság munkáját. ${ }^{417}$ A 2017 -es szabályozás szerint bűncselekményt követ el, aki a bármilyen módon gátolja a hatóságok tevékenységét, amely a terrorizmus elleni fellépésnek minősül, és ezáltal meghatározott mértékü veszélyt jelent a közbiztonságnak és a közrendnek. ${ }^{418}$ Mindezek mellett viszont nem pontosan meghatározott a terrorveszély, a terrorcsoporttal való kapcsolat fogalma, vagy az alkalmazható eszközök esetében a szükségesség és az arányosság. Az előzetes ellenőrzés hiányának oka pedig a jogkorlátozó eszközök átalakítása megelőző eszközökké, és így a 2017-es szabályozásban már hatósági intézkedésként kerültek át a belbiztonsági törvényekbe a korábban különleges jogrendi szabályok közé tartozó intézkedések és eszközök.

Mivel az eszközök egy része már korábban is szerepelt az 1955-ös különleges jogrendi szabályozás keretei között, sokan azt vitatják, hogy a most hatályba lépett új rendelkezések gyakorlatilag a különleges jogrend kivételességét állandósítják. ${ }^{419}$ Az Államtanács felvetésére a kormány úgy válaszolt, hogy az állandósult veszélyekre olyan válasz kell, hogy szülessen, amely a jogállamiság keretei között, állandó eszközöket szolgáltat a terrorizmus elleni harcban. ${ }^{420}$

Az állandósulása ezeknek az eszközöknek különösen veszélyes és meglepő lépés a jogalkotó részéről, mivel nagyfokú veszélyt jelentenek a szabadságjogokra. A belügyminisztérium jelentése szerint a különleges jogrendi időszak alatt 32 terrortámadást sikerült meghiúsítaniuk a hatóságoknak, de mindebből persze nem következik, hogy erre a különleges jogrend keretei között lett volna csak lehetőség, miközben a különleges jogrend alatt bevezethető intézkedések

\footnotetext{
${ }^{417}$ A pontatlan meghatározások miatt az 1955-ös törvény 5. cikkét hatályon kívül helyezték, https://www.conseilconstitutionnel.fr/sites/default/files/as/root/bank_mm/decisions/2017635qpc/2017635qpc.pdf (letöltés dátuma: 2019. 09. 29.)

${ }^{418}$ L'état d'urgence contamine le droit « commun » : la sortie par le fond! Syndicat de la Magistrature, 8 June 2017, http://www.syndicat-magistrature.org/L-etat-d-urgence-contamine-le.html (letöltés dátuma: 2019. 09. 29.); a jogszabályt „mérgezőnek nevezte” az alapjogi biztos Jacques Toubon a Le Monde hasábjain 2017. június 23-án, https://www.lemonde.fr/societe/article/2017/06/23/jacques-toubon-le-projet-de-loi-antiterroriste-est-une-piluleempoisonnee 5149755 3224.html (letöltés dátuma: 2019. 09. 29.); miközben a CNCDH elnöke, Christine Lazerges megvonta a támogatást a további különleges jogrendi formától, illetve annak rendes jogrendi szabályok közé illesztésétöl, interjú, 2017. szeptember 25., https://www.respectmag.com/29773-terrorisme-projet-de-loidangereux (letöltés dátuma: 2019. 09. 29.)

${ }^{419}$ Patrick, WAChSMAnN: L'état d'exception dans le droit commun? In: Recueil Dalloz, 2017/33., pp. 1905-1908.; Emmanuel, DAOUD: Projet de loi renforçant la lutte contre le terrorisme et la sécurité intérieure: la duplicité du Président de la République. Dalloz Actualité. Le 07 Julliet 2017, https://www.dalloz-actualite.fr/chronique/projetde-loi-renforcant-lutte-contre-terrorisme-et-securite-interieure-duplicite-du-presi\#.XdmZxy35dDU $\quad$ (letöltés dátuma: 2019. 09. 29.)

${ }^{420}$ Conseil d'etat Assemblée générale Avis sur un projet de loi prorogeant l'application de la loi n. 55-385 du 3 avril 1955 relative à l'état d'urgence et modifiant son article 6 (n. 392427) séance de jeudi 8 décembre 2016, 6 . pont, http://www.assemblee-nationale.fr/14/pdf/projets/pl4295-ace.pdf (letöltés dátuma: 2019. 09. 29.); https://www.conseil-etat.fr/actualites/discours-et-interventions/presentation-du-conseil-d-etat (letöltés dátuma: 2019.09.29.)
} 
hatékonysága a hosszútávú alkalmazással erősen csökken. ${ }^{421}$ Mindez összességében megkérdőjelezi a különleges jogrendi eszközök átültetésének szükségességét a rendes jogrend keretei közé. Meg kell ugyanakkor jegyeznünk, hogy a belbiztonsági törvénykönyv új rendelkezései ${ }^{422}$ legfeljebb 2020. december 31-ig alkalmazhatók. ${ }^{423}$ Vagyis, végső soron az állandóság mégsem lenne véglegesség, hiszen alkalmazásától számítva kevéssel több, mint 3 évig lehetne csak alkalmazni. Ugyanakkor jusson eszünkbe, hogy ezt megelőzően közel 2 évig volt a különleges jogrend hatályban. Így viszont már összesen 5 évnél járunk, még akkor is, ha a második körben való bevezetésre csak partikulárisan és átmeneti jelleggel van lehetősége a hatóságnak. Ehhez hasonló léptékü intézkedésekre viszont csak valódi nemzetközi fegyveres konfliktusok idején szokott sor kerülni. Franciaországban az átmenetileg bevezetett biztonsági intézkedések már korábban is tartósabbnak bizonyultak. ${ }^{424}$ Főleg azért gondolhatjuk, hogy a későbbiekben módosítani fogják ezt a határidőt, mert a Szenátus eleve abból a célból jelölte ki 2020. december 31-ét, hogy három év alatt az alkalmazott kivételes intézkedések bizonyíthatják arányosságukat. ${ }^{425}$ Ezzel lényegében a francia parlament egyfajta modellkísérletet vezetett be, amely kifejezetten egyes különleges jogrendi elemek rendes jogrendi meghonosítását célozza. ${ }^{426}$

Az 1955-ös különleges jogrendi szabályok felülvizsgálata volt valójában bizonyos szempontból a 2017-es törvény, mivel sok tekintetben keretként tekintett rá a jogalkotó, hiszen a különleges jogrendi szigort kívánja átmenetileg a rendes jogrend keretei között alkalmazni. Ugyanakkor a szabályok sok esteben szigorúbbak, mint az 1955-ösek voltak. ${ }^{427}$ Van lehetőség a védelmi zónán belül különféle további ellenőrzések pl. házkutatás, ruházat és csomagátvizsgálás, valamint gépjármű átvizsgálás alkalmazására, miközben ezt az 1955-ös eredeti szabályozás 8-1 cikke még nem tette lehetővé. További probléma, hogy a vallásgyakorlás helyszínére vonatkozó korlátozások a különleges jogrendi szabályok keretei között szűkebb körbe esnek,

\footnotetext{
421 Assemblée Nationale Rapport d'information n. 4281 sur le contrôle parlementaire de l'état d'urgence, 6 décembre 2016, http://www.assemblee-nationale.fr/14/pdf/rap-info/i4281.pdf (letöltés dátuma: 2019. 09. 29.); a francia különleges jogrend összefoglalására lásd Paul, CASSIA: Contre l'état d'urgence, Dalloz, 2016.

${ }^{422}$ A törvény cikkeit lásd 226-1-től 229-6-ig bezárólag.

${ }^{423}$ A 2017-1510 számú törvény 5. cikke alapján.

${ }^{424}$ Lásd az 1995-ös támadások után bevezetett Vigipirat rendszert, amelyet szintén átmenetinek szántak annak idején.

${ }^{425}$ M. Michel Mercier Sénateur Rapport n. 629. 12 Julliet 2017, https://www.senat.fr/rap/116-629/116-6291.pdf (letöltés dátuma: 2019. 09. 29.)

426 Vö. a MATRIX modellkísérlettel.

${ }^{427}$ Pl. a védelmi zónák kijelölése alapvetően merít az 1955-ös különleges jogrendi szabályokból, miközben az eredeti szabályozás szerint azok legfeljebb 24 óráig voltak bevezethetők, a mostani 2017-es szabályok alapján a belbiztonsági btk módosított szabályai szerint viszont nem haladja meg az egy hónapot.
} 
mint az új szabályozás 227-1 cikke szerint, ugyanis azt is értékeli a jogszabály, hogy ha olyan erőszakot promotáló ideológiát terjesztenek, amely gyülölethez, diszkriminációhoz vagy terrorcselekmény elkövetéséhez járulhat hozzá. Ez így egyes vélemények szerint meglehetősen pontatlan és nehezíti az egységes joggyakorlat kialakulását, illetve a jogkorlátozást kizárólag a diszkrecionális hatósági döntéshez köti, továbbá az érintettek bizonytalan jogszabályi környezetben eshetnek jogkorlátozás alá, amely így a jogbiztonságot erősen sértheti. ${ }^{428} \mathrm{~A}$ korábbi szabályozás ahhoz kötötte az elektronikus megfigyelés foganatosítását, hogy a különleges jogrendet bevezették, például terrorizmus gyanúja vagy más szándékosan elkövetett súlyos büncselekmény gyanúja miatt, ${ }^{429}$ miközben a jogszabály 228-3 cikke ilyen kritériumot nem tartalmaz. Amiben mégis erősebb maradt a különleges jogrend, hogy házkutatás, háziőrizet és lefoglalások csak abban az esetben hajthatók végre a jogszabály 229-1 cikke alapján, ha a hatóság erre irányuló indokolt kezdeményezését a bíró előzetesen jóváhagyta. Különleges jogrenden kívül erre nem kerülhet sor.

Problémát jelenthet, hogy a házkutatást engedélyező bíró csak kivonatosan ismerheti meg a további jogkorlátozást vagy hatósági intézkedést megalapozó tényeket, hiszen ezek sok esetben nemzetbiztonsági szolgálatok által biztosított információból származnak. A különleges jogrendben már korábban is létezett ez a probléma, amikor a büntetőbírónak azt kellett mérlegelnie, hogy a hatósági ellenőrzés, amely során a büncselekmény elkövetését észlelték mennyiben volt szabályos. Erre azt a megoldást javasolta a Cour de Cassation, hogy az ügyben eljáró bíró ún. közbenső kérdésekkel megkeresheti az ügyészt, akinek ezután vizsgálódnia kell a konkrét hatósági lépés indokoltsága és szabályossága vonatkozásában. ${ }^{430}$

Összességében elmondható, hogy az alábbi legfontosabb intézkedések alkalmazását tette lehetővé a törvény:

- jármü és személyforgalom korlátozása bizonyos helyeken, illetve időszakokban

- védelmi vagy biztonsági zónák felállítása, amelyeken belül szabályozott az állampolgárok tartózkodása

\footnotetext{
428 További különbség, hogy ebben az esetben a prefektus hozza meg a döntést, míg az eredeti 1955-ös szabályozásban még a belügyminiszter döntése kellett.

${ }^{429} \mathrm{Az}$ 1955. április 3-án elfogadott 55-385 sz. törvény 6-7. cikkei.

${ }^{430}$ Látva a problémakört az alapjogi biztos azt javasolta, hogy a bíróság rendelkezzen megfelelő hozzáféréssel a minősített dokumentációhoz. (Az alapjogi biztos 2017. július 7-én kelt 17-05 számú véleménye.) https://juridique.defenseurdesdroits.fr/doc num.php?explnum $\mathrm{id}=16676$ (letöltés dátuma: 2019. 09. 29.)
} 
- a hatóságok tevékenységét „bármilyen formában” akadályozó személyek tartózkodásának megtiltása bizonyos területen

- a közrendet súlyosan veszélyeztető egyesületek és egyéb csoportok feloszlatása

- rendezvénytermek, vendéglátó-ipari egységek és egyéb nyilvános helyek átmeneti bezárása

- fegyverek és lőszerek beszolgáltatásának előírása

- a közigazgatási jogkörben, érdemi rendes bírói felülvizsgálat nélkül, egy nap 12 órát meg nem haladó időtartamra, ${ }^{25}$ adott esetben jelentkezési kötelezettséggel társítva a „magatartásukkal a biztonságra és a közrendre komoly veszélyt jelentő" személyek házi örizete (assignation à résidence), amely időközben 12 hónapos maximális időtartamot kapott, amelyet 3 hónappal azonban meg lehet hosszabbítani még; illetve

- a magánlakásokra is kiterjedően „a biztonságra és a közrendre komoly veszélyt jelentő személyek” felkutatása érdekében, közigazgatási jogkörben, bírói engedély nélkül elrendelhető, éjjel-nappal végrehajtható házkutatás (perquisition administrative)

A különleges jogrend bevezetését követően a rendkívüli intézkedések arányát illetően érdemes megtekintenünk a parlamenti vizsgálóbizottság jelentéseit:

$\begin{array}{lll}\text { 2015. 11. 14. - } & \text { házkutatás } & 3594 \mathrm{db} \\ \text { 2016.05.25. } & \text { házi őrizet } & 400 \mathrm{db} \\ & \text { kitiltás } & 540 \mathrm{db} \\ \text { 2016. 07. 22. - } & \text { házkutatás } & 591 \mathrm{db} \\ \text { 2016. 12.22. } & \text { házi őrizet } & 93 \mathrm{db} \\ & \text { kitiltás /belépési tilalom } & 31 \mathrm{db} \\ \text { 2016. 12. 22. }- & \text { háziőrizet } & 68 \mathrm{db} \\ \text { 2017. 06. 15. } & \text { házkutatás } & 141 \mathrm{db}\end{array}$

A statisztikai adatokat a Francia Nemzetgyülés egyik állandó bizottsága, a Jogi Bizottság vizsgálta. ${ }^{431}$

\begin{abstract}
$431 \quad$ http://www2.assemblee-nationale.fr/14/commissions-permanentes/commission-des-lois/controleparlementaire-de-l-etat-d-urgence/controle-parlementaire-de-l-etat-d-urgence/donnees-de-synthese/ donneesrelatives-a-l-application-de-l-etat-d-urgence-du-14-novembre-2015-au-21-juillet-2016/ mesures-administrativesprises-en-application-de-la-loi-n-55-385-du-3-avril-1955 (letöltés dátuma: 2019. 09. 29.)

http://www2.assemblee-nationale.fr/14/commissions-permanentes/commission-des-lois/controle- parlementairede-l-etat-d-urgence/controle-parlementaire-de-l-etat-d-urgence/donnees-de-synthese/ donnees-relatives-a-lapplication-de-1-etat-d-urgence-du-22-juillet-au-21-decembre-2016/synthese- des-mesures-administrativesprises-en-application-de-la-loi-du-3-avril-1955 (letöltés dátuma: 2019. 09. 29.)

http://www2.assemblee-nationale.fr/14/commissions-permanentes/commission-des-lois/controle- parlementairede-l-etat-d-urgence/controle-parlementaire-de-l-etat-d-urgence/donnees-de-synthese/ donnees-relatives-a-lapplication-de-l-etat-d-urgence-depuis-le-22-decembre-2016/synthese-des- mesures-administratives-prises-enapplication-de-la-loi-du-3-avril-1955 (letöltés dátuma: 2019. 09. 29.)
\end{abstract}


A különleges jogrendi időszak alatt bizonyos mértékü visszaélésekre is sor került, mivel a hatóság látókörébe került ártatlan francia muszlimokkal, politikai rendezvényekhez köthető aktivistákkal vagy egyszerü állampolgárokkal szemben foganatosítottak hastósági intézkedéseket. ${ }^{432}$ 


\subsection{Magyarország Alaptörvényének hatodik módosítása}

Magyarország Alaptörvényének hatodik módosítására irányuló képviselői indítványt 2016. április 26-án nyújtották be, majd 2016. június 14-én hirdették ki. Az indítvány indokolásában az Alaptörvény megalkotása óta gyökeresen megváltozott biztonsági környezetre és az új típusú kihívásokra hivatkoznak az előterjesztők. A megállapítás mindkét fele igaz, ugyanakkor több mint 10 évvel a 9/11-es terrortámadást követően kissé anakronisztikus új típusú biztonsági kihívásként utalni a nemzetközi terrorizmusra, bár tény, hogy a hazai szakirodalom meghatározásával ez egybe cseng. ${ }^{433}$ Az előterjesztés részletes indokolása szerint a terrorveszélyhelyzet a megelőző védelmi helyzet belbiztonsági megfelelője. Terrorveszélyhelyzet esetén bevethető a Magyar Honvédség is, amelyre akkor kerülhet sor, ha a Kormány megítélése szerint a rendőrség és nemzetbiztonsági szolgálatok alkalmazása a biztonság fenntartásához nem elégséges. A terrorveszélyhelyzet bevezetésére az Országgyülés jogosult, amelyre a Kormány erre irányuló előterjesztése alapján kerülhet sor. Ebben értelemszerüen az is benne van, hogy a Kormány, mint végrehajtó hatalom közremüködése nélkül a terrorveszélyhelyzet különleges jogrend bevezetésére sem kerülhet sor. A Kormány kivételes intézkedésekkel élhet a terrorveszélyhelyzet bevezetésére irányuló döntés meghozataláig, amelyek érinthetik a rendörség, a nemzetbiztonsági szolgálatok, valamint a Magyar Honvédség szervezetét és müködését, illetve tevékenységüket érintő jogszabályok rendelkezéseitől eltérhet. Az így bevezetett intézkedések hatálya kizárólag a terrorveszélyhelyzet kihirdetésére vonatkozó döntésig, de legfeljebb 15 napig tarthat.

A Magyar Honvédség alkalmazása hatékonyabb és komplexebb védekezést tesz lehetővé, amely indokolta azt is, hogy az új típusú különleges jogrendhez kapcsolódó alacsonyabb szintü jogalkotást is a belügyi és a honvédelmi ágazat párhuzamosan dolgozza ki. ${ }^{434}$

Magyarországon terrorveszélyhelyzet bevezetésére nem került sor ezidáig, amely több tényező együttes, egymásra is ható következménye. Terrorveszélyhelyzet bevezetésére akkor kerülhetne sor, ha terrorcselekményt követnek el vagy terrortámadás jelentős és közvetlen veszélye áll fenn. Az első esetkör egyértelmünek látszik, ugyanakkor nem tisztázza a normaszöveg - és az Alaptörvény hatodik módosítását tartalmazó előterjesztés indokolása sem

\footnotetext{
433 TÁLAs Péter: A terrorveszélyhelyzet-diskurzus margójára. In: Nemzet és biztonság. 2016/1., szám pp. 40-47. ${ }^{434}$ SimicsKó István: A terrorizmus elleni védelem fokozása a különleges jogrendi kategóriák bövítésével. In: Hadtudomány 2016/3-4., p. 101.
} 
-, hogy a különleges jogrend bevezetésekor figyelembe vehető terrorcselekményt Magyarországon vagy külföldön követték-e el. Ehhez a Btk. sem nyújt megfelelö segítséget, hiszen a 314. § szerinti terrorcselekmény tényállása bárhol megvalósítható a világon, a magyar jogrend szerint azonos megítélés alá fog esni.

A másik esetben jelentős és közvetlen veszély kell, hogy fennálljon. A közvetlenség jogi meghatározottsága jelentheti azt, hogy valaminek a bekövetkezése időben szorosan követheti a jogi tény értékelését, vagy vonatkozhat a veszély és annak joghatása közötti ok-okozati összefüggésre. Ebben az esetben az időbeli tényező talán meghatározóbb. A veszély akkor jelentős mértékü, ha az anyagi kár, amellyel közvetlenül fenyeget jelentős mértékü vagy beteljesülése esetén a veszély rendszerszinten fejtené ki negatív hatását az állami szervekre, s így eredményezne közvetetten jelentős mértékű anyagi kárt. A jelentős és közvetlen veszély mértéke rendelkezik tehát jogi meghatározottsággal, ugyanakkor ennek - joghatás kiváltására alkalmas - kimondásához kell a Kormány és az Országgyülés együttműködése. A terrorveszélyhelyzet bevezetéséről az Országgyülés dönt kizárólagosan, ugyanakkor csak abban az esetben járhat el, ha a Kormány erre irányuló elöterjesztését benyújtotta. Vagyis, hasonlóan az ügyészhez, aki a büntetőeljárásban az ügy ura, a terrorveszélyhelyzet bevezetése során is a Kormány kezében van valójában a döntés lehetősége. Az Országgyülés döntése egyszerre jogi és politikai, ezért minden esetben akár vizsgálható a kérdés, hogy a kormánynak van parlamentje vagy a parlamentnek van kormánya. ${ }^{435}$

A terrorizmussal kapcsolatos feladatrendszer szerteágazó, több szervezetet ${ }^{436}$ érint, feladatkörük pedig egymás viszonylatában kiegészítő jellegü. A terrorveszélyhelyzet kihirdetését megalapozó végrehajtott terrorcselekmény egyértelmű, széles körben észlelhető és értelmezhető, legalábbis akkor, ha klasszikus formában ${ }^{437}$ jelentkezik és befejezett cselekményről van szó. A terrorizmus közvetlen veszélye ugyanakkor egy olyan információn alapul, amely a hatáskörrel rendelkező három szervezet valamelyikénél keletkezett. A különleges jogrend kihirdetésére vonatkozó javaslat és az arról szóló döntés politikai kérdéseket

\footnotetext{
435 POKOL, pp. 211-227.

436 A polgári hírszerző nemzetbiztonsági szolgálat és a katonai nemzetbiztonsági szolgálat a nemzetbiztonsági szolgálatokról szóló 1995. évi CXXV. törvény 4. § c) pontja és a 6. § h) és m) pontjai alapján végez terrorizmussal kapcsolatos információszerzést. A rendőrségről szóló 1994. évi XXXIV. törvény 1. § (2) bekezdés 15. pont a) alpontja pedig a rendőrség terrorelhárító szervére utal.

437 A terrorizmus klasszikus formájának a külön szakmai magyarázat nélkül, tehát a laikusok számára is egyértelmü módon a terrorizmussal azonosítható cselekményeket értem, pl. emberölés, emberrablás, építmények és természeti értékek elpusztítása stb.
} 
vet fel, politikai mérlegelés alá esik és a szakmai jelentés ebben az értelemben csak egy jogszabályban hozzávetölegesen rögzített eljárási elem. Hozzávetölegesen, mert konkrét tartalmi kritériumok nem szerepelnek benne. Tehát ebből következik, hogy a Kormánynak politikai mérlegelésével lehetősége van árnyalni ${ }^{438}$ a szakmai jelentésekben megfogalmazott következtetéseket. Az viszont egyértelmünek tünik, hogy a szakmai jelentésnek mindenképpen meg kell előznie a Kormány Országgyülésnek címzett javaslatát.

Erre vonatkozó direkt utasítás vagy a veszély saját hatáskörben való kezelésének lehetősége híján azonban nem látszik teljesen biztosnak egy közvetlen terrorveszélyre figyelmeztető hivatalos - szakmai jelentés, ugyanis ez nem garantálná a továbbiakban a jelentést felterjesztő nemzetbiztonsági szolgálat szakmai érdekeinek maradéktalan érvényesülését. A nemzetbiztonsági érdek részeként megjelenik a törvényben a terrorcselekmények felderítése és megakadályozása. Ugyanakkor vannak olyan feladatok, amelyeken nem osztozik más szervezetekkel, és amelyek minden bizonnyal háttérbe szorulnának egy terrorizmusra fókuszáló centralizált szervezetrendszerben. Egy kémelhárítási ügyben akár tíz évig is tarthat a feldolgozó munka, míg egy nyomozati cselekmény elvégzése többnyire azért ennek töredéke szokott lenni. Terrorveszélyhelyzetben tehát lehetősége van a Kormánynak arra, hogy szervezeti változtatásokat vezessen be átmenetileg a különleges jogrend idejére, amely - Franciaország esetben látjuk - nem feltétlenül tiszavirágéletű. Egységes irányítás alatt a békeidős jogrendben egyébként elkülönülő rendvédelmi, nemzetbiztonsági és katonai szakmai érdekek határai elveszítik addigi kontúrjaikat és olyan irányt vesznek, amely a nemzetbiztonsági szakmai érdeket fogja legkevésbé szolgálni. Terrorveszélyhelyzetben a közbiztonság fenntartása és megőrzése az elsődleges szempont, amely a kormányzati döntéshozatalt motiválja és ez visszhangzik a társadalmi elvárásban is. Magyarán a Kormány legyen ura a helyzetnek. Ennek érdekében a Magyar Honvédség személyi állományát is rendvédelmi feladatok - legalább a Rendőrséggel közös - ellátására fogják vezényelni, míg a nemzetbiztonsági szolgálatoknál a terrorizmus felderítésével foglalkozó szervezeti egység munkáját erősítik meg az olyan szervezeti egységek létszámából, amelyek ebben a vonatkozásban közvetlen relevanciával nem rendelkeznek. Ez nem jelenti azt, hogy a müveleti terület többi része érintetlen maradna, hiszen munkavégzésre onnan is lehet vezényelni az állományt, de a rájuk vonatkozó feladatszabás

\footnotetext{
438 Így a jelentésben szereplő információkból olyan további következtetést vonhat le a Kormány, amellyel csökkenti vagy növeli a közvetlen veszély mértékét vagy közvetlenségét, de akár figyelmen kívül is hagyhatja a jelentést teljes egészében azzal, hogy az információt vagy a jelentésben leírt következtetést értékeli megalapozatlannak.
} 
szinte biztos, hogy kiegészülne a terrorveszélyhelyzet aktualitásaival. Így a látszólag más feladatot ellátó szervezeti egységek is módosított szempontrendszer szerint értékelik a megszerzett információkat a továbbiakban.

Az ágazati és szakmai érdekeket az Alaptörvényben és a vonatkozó jogszabályokban találjuk, amelyek alapvetően az érintett szervezetek állami szervezetrendszerben való elhelyezkedésén, személyi állományuk jogviszonyán és a hatásköri szabályokon alapulnak. Egyértelmüen elkülöníthetünk katonai, rendvédelmi és nemzetbiztonsági szakmai érdeket, amelyeket honvédelmi és belügyi ágazati érdek alá sorolhatunk be. Önálló nemzetbiztonsági ágazatról nem beszélhetünk, mivel hiányzik az egységes szervezetrendszer és a homogén szolgálati jogviszony. Ettől függetlenül fontos, hogy a nemzetbiztonsági szolgálatok milyen szempontrendszer szerint dolgoznak, hiszen jelentéseik nagy mértékben befolyásolhatják a különleges jogrend kihirdetéséről szóló politikai döntést. Konkrét példa híján csak elméleti következtetések alapján állítható, hogy a különleges jogrend kihirdetését alapvetően nem támogatná vagy kezdeményezné önszántából egy nemzetbiztonsági szolgálat, mivel az leginkább a nemzetbiztonsági szakmai érdeket relativizálná, esetleg súlytalanná is tenné a dominanciához jutó katonai vagy rendvédelmi szakmai érdekek mellett. Békeidős jogrendben a nemzetbiztonsági szolgálatok kiemelt pozícióval rendelkeznek a kormányzati döntéshozatal támogatásában, amelyet az Alaptörvény és a jogszabályi környezet garantál. Ezzel szemben egy bizonytalan kimenetelü különleges jogrend, ahol az alapjogok egy csoportjától eltekintve minden változó, közel sem kecsegtet túl vonzó perspektívákkal egy nemzetbiztonsági szolgálat számára, amelynek szakmai és szolgálati (szervezeti) érdekét olyan területek halványítják el, amelyek szakmai szemlélete szinte összeegyeztethetetlen a nemzetbiztonsági látásmóddal. Ezért kijelenthető, hogy különleges jogrend kihirdetésére nemzetbiztonsági szolgálat nagy valószínüséggel nem fog elhamarkodottan javaslatot tenni. 


\subsection{A terrorizmus és a különleges jogrend kapcsolatának összefüggései}

A különleges jogrend arra szolgál, hogy a müködésképtelenné vált államot sajátos átmeneti hatalom koncentrációval újra müködőképessé tegye. A müködőképtelenség klasszikus esetei, ha természeti katasztrófa vagy ipari szerencsétlenség bekövetkezése miatt az állami szervek képtelen ellátni lokálisan a feladataikat. Különleges jogrend bevezetését alapozza meg továbbá, ha az alkotmányos rendet - erőszakos cselekményekkel is - fenyegető belső veszélyek vagy háború okozza az állam müködőképtelenségét. A különleges jogrend bevezetése lényegében az állam túléléséhez szükséges átmeneti arculatváltás, amely a hatalomgyakorlást érinti. A terrorizmus jelenségét a terrorcselekménnyel definiálja a jog. A terrorcselekmény hatását tekintve járhat olyan súlyos fizikai és morális következményekkel, mintha valamelyik klasszikus különleges jogrendi esemény következett volna be. A lényeges különbség azonban az, hogy a terrorcselekmény - a többi különleges jogrendi eseményhez képest - viszonylag rövid ideig tart és következményei is nagyjából átláthatók. A terrorcselekmény bekövetkezése vagy ismétlődése azonban - szemben a többi különleges jogrendi eseménnyel - többnyire inkább bizonytalan marad. A bizonytalanság, vagyis a szabályozást legitimáló veszélyhelyzet esetlegessége olyan elem, amelyet a jogrendszer nem igazán tud kezelni. A terrorizmus különleges jogrendi szabályozása esetében tehát a jogalkotó a bizonytalanságra tekintettel nyúlt a jogrendszerhez. Ellentétben a klasszikus különleges jogrendi eseményekkel, amikor az állam saját fennmaradásához kötődő természetes érdekei a meghatározók, a terrorizmus esetében egy ugyancsak jelentős nemzetközi érdek is megjelenik. Vagyis, a jogalkotót, illetve a különleges jogrend bevezetésekor a döntéshozót befolyásoló politikai elem egyszerre hazai (társadalmi) és nemzetközi.

A különleges jogrend bevezetésére kizárólag az adekvát, normatív nyelven leírható és az alaki jogforrásban leírt állapotok fennállta esetén van lehetőség. A különleges jogrend ellentmondásos. Egyfelől, azt a célt szolgálja, hogy a rendes (békeidős) jogrend által kezelhetetlennek mondott bizonytalanságra jelentsen megoldást. Másfelől, a különleges jogrend ideje alatt tapasztalható, szükségesként elfogadott, de egyébként aránytalan hatalomkoncentráció bevezetésére egy pontosan leírt szabályrendszer alapján kerül sor. Ennek a szabályrendszernek - amely sajátos természete miatt értelemszerüen mindenképpen bizonyosság lesz - az alkalmazását követően nyílik mód a bizonytalan veszélyforrás megszüntetésére. 
A klasszikus különleges jogrendi események létezése közismert, még ha azok pontos mértéke, vagy esetleges kimenetele nem is nyilvánvaló. A többségük mégis szinte kézzel fogható, egyszerü tapasztalás útján mindenki megbizonyosodhat létezésükről. A terrorveszély létezésének vagy mértékének felmérésére viszont legfeljebb a mások által elvégzett értékelések megismerése útján van lehetőségünk. Ez értelemszerűen nem kis mértékben érinti a terrorveszélyhelyzet miatt bevezetett különleges jogrend legitimációját is. A terrorizmus veszélyének mértékét és közvetlenségét csak egy nagyon szük szakmai réteg képes felmérni, amennyire képességei és lehetőségei ezt engedik. A különleges jogrend bevezetéséről döntő politikai közeg is csak szürt információkkal rendelkezik, miközben a döntésére hatással bíró közvélemény teljes mértékig ki van téve a veszély mértékére vonatkozó spekulációknak.

A különleges jogrendben érvényesülő sajátos közjogi viszonyok terrorveszélyre történő alkalmazása egy merőben új gondolat, amelyre azonban a különleges jogrendi időszakra kidolgozott közel egy évszázados dogmatika legfeljebb korlátozottan alkalmazható. 


\section{5. ÖSSZEGZŐ MEGÁLLAPÍTÁSOK}

A kutatás során több aspektusából tettem kísérletet arra, hogy a terrorizmust, mint jogi, politikai, szociológiai és kulturális jelenséget, illetve annak hatásait vizsgáljam. A vizsgálat eredményeként megállapítható, hogy a terrorizmus hatásai rendkívül összetettek, valamint párhuzamosan, illetve rövid- és hosszútávon egyaránt érvényesülnek. A terrorizmus hatásainak maradéktalan és komplex feltérképezésére ugyanúgy nincs lehetőség, mint egy politikai- vagy divatirányzat szociológiai, gazdasági és egyéb hatásainak az összegzett feltérképezésére. A kutatás során ezt valamelyest kompenzálva egy sajátos spirális vizsgálati módszerrel jártam körül az egyébként összetett, jogi, politológiai, rendvédelmi és katonai háttérrel rendelkező hipotéziseket. Az összetett háttér ellenére sikerült mindegyik hipotézis vonatkozásában az állítást igazolni vagy cáfolni. A terrorizmus jelenségét nem sikerült megszüntetni, és ugyan a terrorizmus egy meghatározó jelenség napjainkban, nem mondhatjuk, hogy egy terrorizmus által meghatározott világban élünk.

A terrorizmus sajátos ideológiája miatt a megtámadott állam és a terroristák viszonya (ti. „mi” és „ők”, valamint az „áldozat” és az „agresszor” antagonisztikus szembe állítása egymással) állandósult, amely viszonyrendszerben az aki nincs velünk, ellenünk van alapelv a meghatározó mindkét fél számára. Természetesen ez nem jelenti azt, hogy bármilyen politikai perspektíva vagy az államok időnként megkérdőjelezhető nemzetközi katonai szerepvállalása elbagatellizálhatná a terroristák felelősségét. Abban viszont mindenképpen segíti a terrorizmushoz kapcsolódó folyamatok megértését, hogy az államok nemzetközi kapcsolataiban és a belső jogi (és politikai) viszonyaiban milyen narratíva társul az áldozatsegítéshez, az elszámoltatáshoz, vagy éppen az arányosságot halványabban, de a szükségességet annál hangsúlyosabban hirdető különféle megoldási javaslatokhoz. A kutatás legelején éppen összetettségük miatt esett a választásom a kutatás pilléreit képező három hipotézisre, amelyek igazolására, illetve cáfolatára a kutatás végén az alábbiakban adok választ. 


\subsection{Az első hipotézis cáfolata}

Az értekezés első hipotézise szerint a terrorellenes intézkedések látens módon produkálják egy fegyveres konfliktus belső jogrendszeri hatásait. Több irányból is érkezett utalás arra, hogy a terrorizmus elleni nemzeti vagy nemzetközi fellépés valójában egy háborús konfliktust takar, és eszközrendszere ${ }^{439}$ és céljai ${ }^{440}$ is ez látszottak igazolni. A politikai retorika többnyire nem számít a legmegbízhatóbb forrásnak, legalábbis nem tekinthető kizárólagosnak még egy politikai kérdés értékelésekor sem. Azonban nem hagyható figyelmen kívül, hogy a 9/11-es merényletek óta hangoztatott amerikai álláspontot, miszerint az Egyesült Államok és a „szabad világ" háborút folytat a terrorizmus ellen, ${ }^{441}$ sokakat meggyőzött és elterjedt a háborús jelző használata. ${ }^{442}$ A háborúra, vagy pontosabban a nemzetközi fegyveres konfliktusra, amelyre a szóhasználat utal, részletesen kimunkált nemzetközi jogi szabályok vonatkoznak, amelyek lényegi elemei ráadásul - az ENSZ Alapokmányának részeként - erga omnes hatállyal bírnak. Tehát még akkor is alkalmazandók - és így számon is kérhetök - valamennyi érintett fél részéröl, ha az egyik félnek az oldalán éppen hiányzik az állami lét, amely azért a legtöbb esetben előfeltétel a nemzetközi jog alkalmazhatóságához.

Egy-egy terrorcselekményre rendkívül sok féle módon reagálhat a társadalom, mint morális és mint politikai közösség. Vizsgálható az emberekben individuális és közösségi szinten is az áldozati lét tudatosítása, amelyhez szinte automatikusan társul az ártatlanul megtámadottakat megillető önvédelem joga. Az önvédelem jogát ráadásul a nemzetközi jogban többen kiegészítik a megelőző csapás lehetőségével is. ${ }^{443}$ Mindez még akár a terrorcselekmény hiánya (tipikusan elmaradása vagy meghiúsulása) esetén is kialakulhat, ha az erre vonatkozó információt a szélesebb társadalom tudomására hozzák. ${ }^{444}$ Vagyis elmondható, hogy

\footnotetext{
439 A terrorellenes nemzetközi fellépés „címzettjei” szinte túlnyomó többségben a nemzeti hadseregek. Afganisztántól kezdve, az Iszlám Állam elleni szíriai beavatkozáson keresztül, a Boko Haram felszámolására tett katonai ajánlatig bezárólag egytől-egyig katonai feladatokról beszélhetünk. Hasonlóan, a katonai vagy polgári hírszerzés által megszerzett információk alapján elkövetett célzott drón támadásokat is a hadseregek hajtják végre. ${ }^{440}$ A célpontok, jelesül a terrorszervezet személyi állományának és infrastruktúrájának a fizikai megsemmisítése. ${ }^{441}$ Az Egyesült Államok korábbi elnökének, George W. Bush kormánya által meghirdetett Doctrine of War on Terror.

442 Lásd az afganisztáni és az iraki nemzetközi katonai missziókban résztvevő államok kormányainak kommunikációját.

${ }^{443}$ A kérdés elméleti igazolására irányuló kutatásokat első sorban amerikai és izraeli nemzetközi jogászok körében találunk.

${ }^{444}$ Franciaországban, az Egyesült Királyságban és Hollandiában az elmúlt évek során több esetben számoltak be a kormányzat részéről időben felderített és a hatóságok által meghiúsított terrortámadásokról. Az Európai Unió, partner államok kormányai, és különösen az Egyesült Államok kormánya többször is felhasználta a meghiúsított terrortámadásokat a statisztikák kialakításakor. Vélhetően harmadik államban tervezett és meghiúsított
} 
terrorcselekmények társadalmi hatásait csak igen nehezen és vélhetően egy kizárólag erre irányuló kutatás esetén is csupán korlátozottan lenne lehetőségünk értékelni. A kutatás előkészítésekor ebből a megfontolásból vetettem el a terrorizmus társadalmi hatásainak bevételét az első hipotézisbe. A jogrendszeri hatások ennél egyértelmübbnek tűnnek, hiszen a jogrendszer pillanatfelvételszerü vizsgálata és különösen egy-egy terrortámadásra tekintettel különböző időállapotainak összevetése megmutathatja a terrortámadás tényleges hatásait.

A fegyveres konfliktust a jogrend különleges állapotnak tekinti, amelyet annak függvényében, hogy államközpontú ${ }^{445}$ vagy alkotmányközpontú ${ }^{446}$ jogrendröl beszélünk, helyez a jogrenden kívülre vagy nevez meg egyfajta lex specialisként. ${ }^{447}$ Ugyanakkor az közös bennük, hogy háború idején a rendes, vagy másként békeidős jogrend a háttérbe húzódik, de legalábbis korlátozottan vagy módosítottan érvényesül. Mindenesetre úgy tủnik, hogy a fegyveres konfliktus de facto létezésével együtt jár a de jure elismerés is. Hiszen az államközpontú jogrend esetében jogrenden kívüli eszközök alkalmazásától várják a fegyveres konfliktus megoldását, ugyanakkor a terrorszervezetek elleni fellépésben szinte kizárólagosan a nemzetközi és a nemzeti jog hatálya alatt müködő katonai és rendőri szervezetek vesznek részt. Felhatalmazásukat a békeidős jogrendből eredeztetik, eljárásukat a békeidős jogrend alapján értékeli a jog. Az alkotmányközpontú jogrend esetében ez még nyilvánvalóbb, hiszen a háborús különleges jogrend bevezetését megelőzően szükséges az erre felhatalmazott szerv(ek) formalizált döntése. Erre a jogrendszeri elismerésre viszont nem került sor a terrorizmus elleni fellépések során.

További ellentmondás jelentkezik, ha azt vizsgáljuk, hogy a háborús (értsd: nemzetközi fegyveres konfliktus) szóhasználat és a terrorizmus elleni állami (szinguláris vagy koordinált) fellépés gyakorlati elemei között legtöbbször nincs összefüggés. Ez alól alakilag kivételt képez az ISIS elleni összehangolt nemzetközi katonai fellépés. Anyagi jogi értelemben véve ugyanakkor, egy klasszikus nem nemzetközi fegyveres konfliktussal állunk szemben. Az ISIS elleni koalíciós katonai fellépés nemzetközi jellege vitathatatlan, amelyet kiegészít a terrorszervezethez mérten - jelentős méretü területiség is. A nemzetközi humanitárius jog

\footnotetext{
terrortámadásról viszont csak az érintett állam kormányával egyeztetve és előzetes hozzájárulása alapján adhatnak számot.

${ }^{445}$ Ebben az esetben az állam ab ovo rendelkezik a szükséghelyzetből eredő íratlan és a pozitív jog felett álló jogosultsággal, amelyet a pozitív jog sohasem képes korlátozni.

${ }^{446}$ Ebben az esetben pedig a különleges állapotra nem, mint az alkotmányosság határain kívül álló helyzetre, hanem mint az alkotmányban rögzített eljárásrendre kell gondolni.

${ }^{447}$ JAKAB - TILL, pp. 470-471.
} 
(IHL) szerepe és jelentősége egyértelmű, a fegyveres konfliktus nemzetközi (international armed conflict, IAC) vagy nem nemzetközi (non-international armed conflict, NIAC) minősége mellett egyaránt. Ugyanakkor egy mögöttes, de annál lényegesebb kérdést is eldönt, ha kimondjuk, hogy az ISIS ellen vívott harc nemzetközi fegyveres konfliktusnak minősül. Ezzel ugyanis implicit kimondanánk azt is, hogy a nemzetközi közösség elismeri az ISIS államiságát. Vagyis, bármennyire is háborúnak tünik a túlnyomó részt Szíria területén folytatott harc, az események nemzetközi jogi klasszifikációja alapján nem nemzetközi fegyveres konfliktusról (NIAC) van szó. ${ }^{448}$

Összességében elmondható, hogy a terrorizmus elleni állami fellépés nem hordozza a nemzetközi fegyveres konfliktusok szokásos stílusjegyeit (pl. általános mozgósítás, a teljes államigazgatás különleges jogrendi müködésére történő átállás elrendelése). Az egyetlen kivételnek tekinthető, amikor az Egyesült Államok a 9/11-es merényletre tekintettel felhívta az Észak-Atlanti Szerződés 5. cikkelyét szövetségesei számára. A Bush-kormányzat háborús retorikája sikereket hozott a politika nemzeti és nemzetközi szintjein. A kommunikáció jogtudományi megítélése azonban már jelentősen árnyalt volt. ${ }^{449}$ A nemzetközi jogi klasszifikáció mellett sem mutatható ki olyan mértékben bárminemü belső jogi jogrendszeri változás, amely igazolni tudná, hogy a nemzetközi terrorizmus elleni katonai fellépés a nemzetközi fegyveres konfliktusnak ekvivalense lehet. Ezen értelemszerüen az sem változtat, ha a politikai retorika kizárólagosan használja és emiatt a közbeszéd átveszi a háború fogalmát.

\footnotetext{
${ }^{448}$ Lásd bővebben Ahmed AL-DAwoody: Non-International Armed Conflicts under Islamic Law: The Case of ISIS. In: Nuremberg Academy Series, 2018/2., pp. 121-143.; Terry D. GILL: Classifying the Conflict in Syria. In: International Law Studies 2016/1., pp. 353-380.; Vaios Koutroulis: The Fight Against the Islamic State and Jus in bello. In: Leiden Journal of International Law 2016/3., pp. 827-852.

449 Alex P. SCHMID: Terrorism - The Definitional Problem. In: Case Western Reserve Journal of International Law 2004/2., pp. 375-419.; Tom GAL: Legal Classification of the Conflict(s) in Syria. In: The Syrian War. Between Justice and Political Reality. (eds.) Hilly Moodrick-Even KHEN, Nir T. Boms, Sareta AsHRAPH. Cambridge University Press 2020., pp. 29-55.
} 


\subsection{A második hipotézis igazolása}

A kutatás második hipotézise szerint az alkalmazott terrorellenes jogi eszközök közötti fokozatosság eltünt. A terrorellenes eszközök rendkívül széleskörben fordulnak elö, felosztásuk is ennek megfelelően többféle lehet. Az eszközök lehetnek: jogalkotást igénylő és jogalkotást nem igénylő eszközök. Előbbiek minden esetben a jogrendszeren belül fognak elhelyezkedni, utóbbiak viszont nem kizárólagosan jogrendszeren kívüliek. További felosztási lehetőség, hogy büntetőjogi (vagyis ultima ratio-jellegü) vagy nem büntetőjogi (egyéb) eszközökről beszélünk. Az alkalmazott eszközök között különbséget tehetünk az alapján, hogy közjogi vagy magánjogi jellegük a meghatározó. Végül pedig a rendes (békeidős) jogrendi és a különleges jogrendi eszközök között tehetünk különbséget. A fokozatosság ennek megfelelően a különféle felosztási módszerek közötti érzékelhető határ eltünését fogja jelenteni.

A terrorcselekményekhez ${ }^{450}$ közvetlenül kapcsolódhat jogalkotás és egyéb típusú intézkedés, amelyek elsődlegesen azt a célt szolgálják, hogy minél hatékonyabban lépjenek fel a hatóságok a veszélyt jelentő személyekkel és szervezetekkel szemben. A terrorcselekmény bekövetkezése jelentős mértékben zavarhatja meg a társadalmi és politikai folyamatok stabilitását, ráadásul egy terrorcselekmény rendszerint hosszan fejti ki hatását. A terrorcselekmény utóhatása az idő múlásával enyhül és meg is szünhet, de adott esetben tartósan is megvetheti lábát a jogrendszerben. Az életszakaszait ennek megfelelően feloszthatjuk 1) közvetlen hatásokra, amelyek a terrorcselekményhez időben a legközelebb állnak és jellegzetességei az idő múlásával elenyésznek. Ilyenek pl. a terrorveszélyre tekintettel bevezetett különleges jogrend vagy a különleges jogrend bevezetése nélkül elrendelt kiemelt rendőri vagy esetenként katonai jelenlét. A 2) középtávon érvényesülő hatások még részben lehetnek közvetlen hatások (pl. ha a különleges jogrend bevezetése nélkül elrendelt kiemelt rendőri jelenlét hosszabb távon érvényesül). Ugyanakkor a terrorcselekmény utóhatásait tekintve középtávon megjelennek a közvetett hatások is. Azért csak középtávon, mert ezeknek a megjelenéséhez szükséges egy minimális idő eltelte, ti. bizonyos eljárásokhoz kötődnek (pl. törvénykezés), vagy a terrorcselekményre tekintettel megváltozott viszonyokhoz idomulnak (másként: adaptálódnak) a társadalmi és gazdasági viszonyok. A középtávon érvényesülő közvetlen hatások idővel elhalnak és átadják helyüket a továbbiakban kizárólagosan létező közvetett hatásoknak. A közvetett hatások így, erre alkalmas táptalajt nyújtó nemzeti és nemzetközi politikai, gazdasági

\footnotetext{
${ }^{450}$ A megvalósult és meghiúsult terrorcselekmény egyaránt szolgálhat ilyen indikátorként.
} 
stb. viszonyok között képesek hosszútávon, idővel észrevétlenül is befolyásolni életünket (pl. közösségi média használata, fegyvertartási jog korlátozása, közösségi- és légiközlekedési szabályok módosulása, épített környezet átalakítása).

A terrorcselekményt közvetlenül követő időszakban - a sokkhatás elmúlását követően kialakul egy erős és alapvetően rövid távon szignifikáns eredményvárás. A társadalom részéről az állam irányába, valamint a kormány részéről a közigazgatási szervek irányába. Mindeközben a nemzetközi kapcsolatokat törekszik a kormány a terrorcselekményért felelősek elszámoltatásának szolgálatába állítani. Az eredményvárással egyidejűleg a lakosság és a kormány részéről egyfajta bizalmi kilengés tapasztalható abba az irányba, ahonnan a segítséget várják. Az eredményvárás és a szokásoshoz képest túlzott bizalom csak rövid távon érvényesülnek, az idő múlásával lecsökken és a továbbiakban nem is tér vissza. Ezen az sem változtat, ha a várakozásoknak megfelelően jelentős eredményeket érnek el a felelősök kézre kerítésében. Idővel a társadalom fókusza megváltozik és a korábban ideiglenesen elviselt - és többnyire eleve átmenetinek is tekintett - korlátozó intézkedéseket terhesnek kezdik érezni és a továbbiakban bírálják. Ezen tehát az sem változtat, ha a felelősöket sikerül rövid idő alatt beazonosítani és megindul velük szemben a büntetőeljárás. A biztonság és a szabadságjogok iránti igények egyidejüleg érvényesülnek és egymás ellen hatnak. Hasonlóan egy inga mozgásához, erre a viszonyra a tehetetlenség lesz a jellemző, amelyet a terrorcselekmény, mint külső erőhatás fog kilengetni. A közvetlen hatásokat tekintve az inga példa feltétlenül adekvát, vagyis egy ideig az erőhatás miatt kilengő, békeidős szemlélettel nézve akár szélsőségesnek is tekinthető intézkedések lesznek a jellemzőek. Idővel ezek lecsengenek, ahogyan az inga is nyugvópontra kerül. Ezzel szemben a közvetetten érvényesülő hatásokra nem az ingát lehetne példaként felhozni. Sokkal jobban leírja a közép- és hosszútávú folyamatokat a spirál, amely látszólag visszatér a kilengést követően, de ténylegesen már nem lesz egyezés a kiindulópont és a végső állapot között. Ahogyan a jogrendszer sem lesz ugyanaz, ha egyszer a részévé vált egy olyan szabály, amely kifejezetten a terrorcselekményre tekintettel került bele.

A fokozatosság elvét ott is erodálódni látjuk, amikor egy látszólag azonos módon kategorizálható terrorcselekményre nem ugyanazon módon adunk választ. Abban az esetben például, ha a közlekedési morál leromlik egy országban és elszaporodnak az emberi életet követelő közlekedési balesetek, megnövelik a közúti ellenörzések számát, megemelik a gyorshajtásért kiszabható bírság mértékét és végső soron módosítják a közlekedési szabályokat. A terrorizmus esetében azonban egy viszonylag érintetlen társadalomban alapvetően a 
zérótolerancia érvényesül. Vagyis már egy elkövetett terrorcselekmény is több, mint amit az emberek türéshatára befogad. A terrorizmus által folyamatosan veszélyeztetett állam lakossága már máshogy reagál a terrorcselekményekre, de meglepően rövid idő elegendő ahhoz, hogy újra a zérótolerancia legyen a meghatározó. Vélhetően az áll a jelenség mögött, hogy az emberek alapvető szükségletként tekintenek a biztonságra és a terrorizmus kiszámíthatatlansága mindenkit folyamatosan bizonytalanságban tart.

Bizonyos szempontból ráadásul a fordított fokozatosság elve érvényesül a terrorizmus ellenes fellépés során. A terrorcselekményt közvetlenül követő időszakban a reakciók szinte szélsőségesek. Az indulatok lecsengését követően pedig a megelőzésre fognak koncentrálni az állami szervek. Vagyis a legintenzívebb, legsúlyosabb, tipikusan ultima ratio-jellegü intézkedéseket hozza meg hamarabb a kormányzat, míg a legenyhébb, jellemzően a közoktatásra és az állami szociális hálózatra épülö radikalizációt megelőző és észlelő felhívás az intézkedések között az utolsó a sorban, amelyet meghoznak. Elmondható tehát, hogy a klasszikus értelemben vett fokozatosság, amely alapvetően meghatározó a jogalkotás folyamatában, a terrorizmus hatására korlátozottan vagy éppen fordított sorrendben érvényesül, vagy teljes mértékig ignorálják. 


\subsection{A harmadik hipotézis igazolása}

A kutatás harmadik hipotézise szerint a nemzetközi terrorizmus azt a hatást váltja ki, hogy közvetlen fenyegetettség nélkül is, vagyis lényegében áttétesen egy sajátos, spirális védekező pályára állítja a jogrendszert. A kutatás ennek a hipotézisnek a vonatkozásában azzal a további feltételezéssel élt, hogy bizonyos közösségi szinten megtapasztalható érzelmeket, amelyek befolyással bírnak a közösség által meghatározott politikára, azonos vagy legalább hasonló módon él át több politikai közösség is. Ez az érzelem pedig a félelem, illetve a kutatás vonatkozásában különösen: a (nemzetközi) terrorizmus által kiváltott félelem.

Vitatható sikereket jelenthet az, ha egy tudományos tézis alátámasztására egy másik tudományterületről behozott viszonyítási módszerrel teszünk kísérletet. Ugyanakkor, ebben az esetben nem erről van szó. Hiszen a félelmet, csupán, mint a látszólag random módon megjelenő párhuzamos események egy további viszonyítási pontját határozom meg. Vagyis, ha egy terrorfenyegetettség azonos időben és több helyen is megjelenik, ${ }^{451}$ akkor ezek önmagukban is elindítanak egy reaktív folyamatot az államigazgatásban ${ }^{452}$ és a politikai vonalon. ${ }^{453}$ Azonban, a terrorfenyegetettséggel kapcsolatban adott (köz)jogi és politikai válaszok a tényleges veszély mértékével ritkábban, sőt általában nem állnak megfelelő arányosságban. Ebben szerepet játszanak azok a tényezők, hogy a politikai döntéshozók nem minden esetben rendelkeznek megfelelő információkkal a terrorfenyegetettség mértékét illetően. Felmerül továbbá az az elvi kérdés, hogy egyáltalán lehetséges-e a terrorfenyegetettség mértékének valós idejü kimutatása. Amennyiben a válasz igen, egy további szempont, hogy alkalmas-e a központi államigazgatás arra, hogy erre azonos időben megfelelően reagáljon.

Vagyis, a számtalan bizonytalanság közepette bizonyosság, hogy 1) a terrorfenyegetettségre születik egy fajta válasz, még akkor is, ha annak a mértéke többnyire nem tekinthető adekvátnak. A válasz megszületése 2) minden esetben politikai diskurzus által meghatározott, mivel jogszabály keretei között fogalmazzák meg vagy a válasz maga a jogszabály. Végső soron pedig, 3) a nemzeti politikára a külső tényezők (pl. nemzetközi kapcsolatok rendszere, közös tradíciók vagy empátia) is befolyással vannak, amelyek közvetett (pl. a választói akarat

\footnotetext{
${ }^{451} \mathrm{Pl}$. az afganisztáni misszióban résztvevő valamennyi államot megfenyegetnek radikális iszlámista szervezetek. ${ }^{452}$ Ezek tipikusan: a külképviseletek épületei és dolgozói, az állami intézmények, sport- és diplomáciai események fokozott védelmének az elrendelése, a különösen veszélyeztetett személyeknek (politikai döntéshozók, katonaiés rendőri vezetők, diplomatát és közvetlen hozzátartozóik) elővigyázatosságának elöírása stb.

${ }^{453} \mathrm{Pl}$. a terrorfenyegetés politikai elítélése, felszólítás a terrorizmus elleni nemzetközi fellépésre stb.
} 
felismerése) vagy közvetlen (pl. egy-egy kérdés kormányzati megítélése) módon érvényesülnek.

A kutatás hipotézisének az igazolásában a félelem citálása abban a vonatkozásban játszik tehát szerepet, hogy az egyébként is meglévő és igazolható összefüggések magyarázatához nyújt segítséget, illetve helyezi más megvilágításba őket.

A kutatás során alapvetően két csoportba soroltam a félelem sajátos interpretációját, annak eredete alapján. Belső eredetü (politikai interpretáció és politikai érdek), valamint külső eredetü (közös kulturális alapok, empátia, politikai szövetség és katonai szövetség) kategóriákat vizsgáltam. A megadott szempontok alapján kimutatható összefüggést állapítottam meg az időben szoros egymásutániságot mutató, azonos tárgyban született jogalkotási termékek között, amelyeket úgy hoztak különböző nemzeti parlamentek, hogy nem mindenhol történt terrortámadás, illetve a terrorfenyegetettség sem volt soha azonos fokon. A belső és a külső eredetű interpretációk egyfajta hidat képeznek, amely táptalajt jelent a valós veszély nélküli fenyegetettség-érzés kialakulásának. A belső és külső eredetű interpretációk minden esetben párhuzamosan jelentkeznek, illetve pontosabban megfogalmazva: rendkívül nehéz, szinte lehetetlen megállapítani azt, hogy ténylegesen melyik előzte meg a másikat. Ugyanis, ha az egyik kialakul, azt a másik is szokta követni, az összefüggéseket pedig nehéz a gyökerekig visszafejteni. 


\subsection{Zárógondolatok}

A kutatást 2010-ben kezdtem, amikor - közel 10 évvel a 9/11-es terrortámadás után - a terrorizmussal kapcsolatos intenzíven ütemezett intézkedéseket már a jogalkotó által kimunkált tételes jog váltotta fel. Az átmeneti végrehajtói döntések helyét a törvényhozó véglegesnek szánt jogalkotási termékei vették át szinte mindenhol. Ezért a kutatást ekkor a terrorellenes jogalkotásra fókuszáltam. Ekkor merült fel bennem egy hazai rendezésű, tematikus nemzetközi konferencia alapgondolata, amelyet az egyetemi közeg helyett végül a Belügyminisztérium rendezett meg, többek között magas szintű európai uniós és amerikai képviselettel. ${ }^{454} \mathrm{~A}$ konferencia programjának kialakításában is volt lehetőségem közremüködni. A 2012-2017 közötti időszak terrorizmusa viszont jelentős változásokat hozott Európában a végrehajtói intézkedések, a jogalkotó és a különleges jogrend szerepének újra- és átértékelésében. A terrorszervezetek radikalizációs és toborzó tevékenysége európai fiatalokra irányult, akik - a terrorcselekmény elkövetéséig - nem tüntek szignifikáns veszélyforrásnak a hatóságok szemében. A terrortámadások összehangolása és a 9/11-es látványos terrortámadás helyett megjelenő lokálisabb és - az alkalmazott eszközök vonatkozásában - kisebb léptékü terrortámadások csak elmélyítették a bizonytalanságot és a félelmet a lakosságban. Az ISIS megjelenése pedig bebizonyította, hogy a müködésképtelen állam helyét akár egy terrorszervezet is átveheti, ezzel pedig territoriális hatalmat gyakorolhat, amelyet idáig csak az államok mondhattak el magukról.

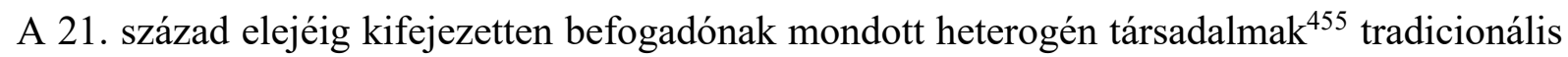
politikai struktúrai átrendeződtek, s ebben a megváltozott biztonságpolitikai környezetben a terrorizmus lett az egyik jelentős viszonyítási pont a politikában. ${ }^{456}$ A terrorizmus leküzdése kapcsán hagyományosan a jogállamiság megőrzését tűzik ki az államok zászlajukra. ${ }^{457} \mathrm{Az}$ elmúlt évtized viszont egyértelmüen a biztonságról szólt, a jogállamiság viszonylagos jelleggel merült csak fel és többnyire ex post facto megközelítésben. ${ }^{458}$ A közvéleményt rabul ejtő

\footnotetext{
${ }^{454}$ A terrorizmus és demokrácia a 21. században c. konferencia (2011. szeptember 29-30.).

${ }^{455}$ Vö. Radicalisation and counter-radicalisation: A gender perspective. Briefing of the European Parliament. 2018 január http://www.europarl.europa.eu/EPRS/EPRS-Briefing-581955-Radicalisation-gender-perspective-rev-FINAL.pdf (letöltés dátuma: 2019. 09. 29.)

${ }^{456}$ Daniel L., BYMAN: How terrorism undermines democracy. 2019. március 5. (a továbbiakban: BYMAN) https://www.brookings.edu/blog/order-from-chaos/2019/03/05/how-terrorism-undermines-democracy/ (letöltés dátuma: 2019. 09. 29.)

${ }^{457}$ Petra, BÁRD (szerk.): The Rule of Law and Terrorism. HVG-Orac 2015.

458 Anders, HENRIKSEN: A small contribution on the rule of law and and anti-terrorism. 2010. https://www.advokatsamfundet.dk/Service/English/Publications/ /media/Engelsk/Darragh\%20K\%20Connell\%2
} 
félelem a jogállamiságot féltőket és az alapvető jogokért felszólalókat a politikai spektrum szélére száműzte, miközben a korábban hagyományosan szélsőségesnek tartott politikai agenda egyre vonzóbbá vált a terrorizmus által megérintett társadalmakban. ${ }^{459}$

Az államok közötti nemzetközi kapcsolatokra is gyakorolt hatást a terrorizmus, hiszen a hidegháborút meghatározó gazdasági-politikai és katonai megkülönböztetés ${ }^{460}$ helyett ma elsődlegesen úgy disztingválhatunk, ${ }^{461}$ hogy vannak a terrorizmus ellen aktívan fellépő államok és azok, amelyek nem tartoznak ebbe a kategóriába. Utóbbi kategóriába tartozó államokat időnként a terrorizmus támogatásával is vádolnak. ${ }^{462}$ A katonai szövetségi rendszerek és a biztonságpolitikájuk alapján hagyományosan szövetségesnek tekintett államok a terrorizmus ellen is közösen vagy egymásra tekintettel lépnek fel. ${ }^{463} \mathrm{~A}$ terrorizmus ellenes nemzetközi együttmüködésekben való részvétel - az előző megállapításra tekintettel - szinte a ius cogens tárgyú nemzetközi szerződésekhez hasonló módon elvárt. ${ }^{464}$ Ahogyan szembetűnő az is, hogy a gazdasági-kereskedelmi tárgyú nemzetközi szerződések megkötését megelőzően, vagy legkésőbb azzal párhuzamosan, a terrorizmus elleni fellépésről ${ }^{465}$ is kötnek szerződést az érintett államok.

A terrorizmusra adott - természetéböl fakadó és azzal összeegyeztethető - jogállami reakció az lenne, hogy a terroristákat, mint büntetőjogi tényállást megvalósító személyeket felelősségre

0-\%20Defending\%20the $\% 20$ rule $\% 20$ of $\% 20$ law $\% 20$ in $\% 20$ challenging\%20times.ashx (letöltés dátuma: 2019. 09. 29.); Darragh K., ConNell: Defending the Rule of Law in Challenging Times: A Legal and Philosophical Discourse. 2010 ., https://www.advokatsamfundet.dk/Service/English/Publications/ /media/Engelsk/Anders\%20Henriksen\%20bidr ag\%20til\%20adv\%20samfundet\%2019112010.ashx (letöltés dátuma: 2019. 09. 29.). A lábjegyzetben hivatkozott források a dán ügyvédi kamara által kiírt jogállamiság projekt 1. és 3. helyezett pályamunkái voltak.

459 BYMAN

${ }^{460}$ Vö. Francis, FukUYAMA: The End of History? In: The National Interest 1989/16., pp. 3-18.; Henry, KISSINGER: Diplomácia. Panem Könyvkiadó, 2007., p. 6.

${ }_{461}$ State Sponsors of Terrorism https://2001-2009.state.gov/s/ct/c14151.htm (letöltés dátuma: 2019. 09. 29.); Kirill, ZHIRKOv, Maykel, VeRKUYTEN, Jeroen, WEESIE: Perceptions of world politics and support for terrorism among Muslims: Evidence from Muslim countires and Western Europe. In: Conflict Management and Peace Science 2014/5., pp. 481-501.; https://www.diplomatie.gouv.fr/en/french-foreign-policy/security-disarmamentand-non-proliferation/france-s-international-action-against-terrorism/ (letöltés dátuma: 2019. 09. 29.); Kaustav, ChAKRABARTI: Terrorism: Challanges to Politics, Society and International Relations. In: Jadavpur Journal of International Relations 2008/1., pp. 139-155.

${ }^{462}$ Ld. az ún. Bush-doktrínát.

${ }^{463}$ Amanda, SKULDT: Terrorism and Foreign Policy. International Studies. Oxford University Press. 2010; Nargis, ZAHRA: Terrorism, Realism and the State. In: Pakistan Horizon 1. szám 2011/1., pp. 61-74.

${ }_{464}$ Aniel Caro, DE BEER: Peremptory Norms of General International Law (Jus Cogens) and the Prohibition if Terrorism. Koninklijke Brill NV, Leiden 2019.; Sofie G. SYED: Sovereign Immunity and Jus Cogens: Is There a Terrorism Exception for Conduct-Based Immunity? In: Columbia Journal of Law and Social Problems 2016/2., pp. 251-293.; Andrea, BIANCHI: Human Rights and the Magic of Jus Cogens. In: The European Journal of International Law 2008/3., pp. 491-508.

${ }^{465}$ Jellemzően adatcsere egyezmények. 
vonják, vagyis független bíróságnak kell őket elítélni. Ahogyan arról a dolgozatban korábban szó volt, minderre sor kerülhet rendes bíróság előtti eljárásban, vagy katonai bíróság előtt. Mindehhez pedig társul még a speciális terrorizmusra szakosodott bíróságokról szóló vita, amelyről szintén korábban már volt szó. A terroristák élethez való jogát vizsgálta a McCann és társai ügyben hozott EJEB döntés ${ }^{466}$ is. Az Egyezmény ${ }^{467}$ szerint az élet kioltását akkor eredményezheti állami szervek fellépése, ha az feltétlenül szükséges. A terroristákat adekvát, a büntetőeljárásban is helytálló információk hiányában nem minden esetben van lehetőség elítélni, továbbá előfordulhat, hogy elítélésük után a fogvatartás aránytalanul nagy kockázattal járna. Ezért már korábban is bevett gyakorlat ${ }^{468}$ volt az államok részéröl, hogy célzott likvidálással oldják fel a gordiuszi csomót. A hadiipar fejlődése, konkrétan a pilóta nélküli gépek fejlesztése és ennek folyományaként a drón-támadások megteremtették annak a lehetőségét, hogy úgy hajtson végre egy állam célzott likvidálást, hogy az érintett harmadik állam területi szuverenitását csak a légtérhasználatban érinti. Minderre sor kerülhet persze úgy is, hogy az érintett harmadik állam tud a tervezett akcióról, illetve konkrétumok nélkül is köthetnek az államok olyan megállapodást, amely a terrorizmussal kapcsolatos katonai együttmüködésről szól, amelynek része lehet akár - az érintett állam előzetes tájékoztatását követő - támadó jellegü katonai légtérhasználat is. A problémakör ebben az esetben nem csupán abból áll, hogy a terroristák meggyilkolásának morális és jogi megalapozottságát ütköztetjük egy szükségszerüen pragmatikus megfontolással, hanem a végrehajtás mikéntjét is rendkívül nehéz jogi keretek közé szorítani.

A terrorizmus sok tekintetben átalakította életünket és a 21. század első két évtizedében jórészt a 2008-ban kezdődött gazdasági világválságtól eltekintve - szinte végig uralta a címlapokat. A terrorizmus jelenségéhez a nyugati társadalmak szükségszerüségből hozzá szoktak. A terrorizmus miatti veszélyérzet bizonytalanságot és félelmet szül. A terrorizmusra adott jogalkotási, igazgatási és jogalkotást nem igénylő válaszok, csak úgy, mint tárgyuk, a minnapok részévé váltak. A biztonság érzése iránti vágy rugalmasabbá teszi az emberek türőképességét, amely nyilvánvaló a szinte mindenhol előforduló biztonsági

\footnotetext{
${ }^{466}$ McCann és Társai v. Egyesült Királyság, 18984/91. (ECHR)

${ }^{467}$ Emberi Jogok Európai Egyezménye 2. cikk.

${ }^{468}$ A teljesség igénye nélkül néhány a célzott likvidálások gyakorlatának jogtudományi és bírói feldolgozásából. Az izraeli legfelsőbb bíróság döntése a Public Committee Against Torture v. Government ügyben (HCJ 769/02); David KRETZMER: Targeted Killing of Suspected Terrorists: Extra-Judicial Executions or Legitimate Means of Defence. In: European Journal of International Law 2002/2., pp. 171-212.; Orna BEN-NAFTALI, Karen R. MIKAELI: We must not make a scarecrow of the law: A legal analysis of the israeli policy of targeted killings. In: Cornell International Law Journal 2003/2., pp. 233-292.
} 
ellenőrzéseknek, ${ }^{469}$ valamint a privátszféra újabb és újabb korlátozásainak társadalmi megítélésében. A jogállami eszményekhez ragaszkodnunk kell, az alapvető jogok védelme érdekében pedig mindig érdemes óvatos bizalmatlansággal közelíteni a korlátozásukra irányuló törekvésekhez. A biztonság garantálása nem lehet kizárólagos szempont és nem adhat végleges felmentést a megalapozatlan és aránytalan jogkorlátozásra. Az alapvető jogok egyidejü, párhuzamos gyakorlására olykor-olykor csak egymásra tekintettel, korlátozott mértékben van lehetőség. Ahogyan a terrorizmus veszélye miatt csorbát szenvedő intézményi jogok és a természetes személyeket megillető alapvető jogok korlátozása is csak abban az esetben érhet célt, ha a korlátozás átmeneti. Hiszen, ha a veszély elmúltával nem állítjuk vissza az eredeti állapotot, a jogállami értékek annak ellenére vesznek el, hogy a terroristák elvileg nem győztek.

\footnotetext{
469 Tipikusan ilyenek az utazást megelőzően a repülőtéren, vasútipályaudvaron és hajókikötőben végrehajtott ellenőrzések és a terrorveszély miatt szokásossá vált közúti és a schengeni belső határokon kialakított átmeneti ellenőrzö-áteresztő pontok. Alexandre G., BARROs, David D., TOMBER: Quantitative Analysis of Passenger and Baggage Security Screening at Airports. In: Journal of Advanced Transportation 2007/2., pp. 171-193.; az amerikai Transportation Security Administration által közölt statisztikák, valamint az Egyesült Királyság kormánya által közölt Air passenger experience of security screening.
} 


\section{FELHASZNÁLT IRODALOM}

Max, Abrahms, Matthew, Ward, Ryan, Kennedy: Explaining Civillian Attacks: Terrorist Networks, Principal-Agent Problems and Target Selection. In: Perspectives on Terrorism. Terrorism Research Initiative 2018/1.

Bruce ACKERMAN: This Is Not a War. In: The Yale Law Journal 2004/8.

Bruce, ACKERmAn: The Emergency Constitution. In: Yale Law School Legal Scholarship Repository, Faculty Scholarship Series, Yale Law School, New Haven 2004.

David, ANDERSON: Control Orders in 2011. Final Report of the Independent Reviewer ont he Prevention of Terrorism Act 2005. The Stationery Office 2012.

Carl A., Auerbach: The Communist Control Act of 1954: A Proposed Legal-Political Theory of Free Speech. In: The University of Chicago Law Review 1956/2.

David, APTER: The Poiltics of Modernization. University of Chicago Press, Chicago 1965.

ARISZTOTELÉSZ: Politika (ford. SzABÓ Miklós) Gondolat, Budapest 1994.

Hadley, Arkes: The Axioms of Public Policy. In: David F., Forte (ed.): Natural Law and Comtemporary Public Policy. Georgetown University Press, Washington DC 1998.

Kenneth, ARrow: Social Choice and Individual Values. Yale University Press, New Haven 1963.

ÁDÁM Antal: A biztonság az értékek között. In: Jura 2005/1.

ÁDÁNY Tamás Vince: A Nemzetközi Büntetőbiróság joghatósága. Elözmények, tendenciák és előfeltételek. Pázmány Press Budapest 2014.

David Mc. A., BAKER: The Effects of Terrorism on the Travel and Tourism Industry. In: International Journal of Religous Tourism and Pilgrimage 2014/1.

Alexandre G., BARros, David D., TOMBER: Quantitative Analysis of Passenger and Baggage Security Screening at Airports. In: Journal of Advanced Transportation 2007/2.

BARTKÓ Róbert: A terrorizmus elleni küzdelem kriminálpolitikai kérdései. Universitas-Győr 2011.

Mary, BARTON: The British Empire and International Terrorism: India's Spearate Path at the League of Nations, 1934-1937. In: Journal of British Studies. The North American Conference on British Studies 2017/2.

BÁNYÁSz Péter: A közösségi média lehetőségei és kihivásai a védelmi szférában. Doktori értekezés 2018.

Petra, BÁRD (szerk.): The Rule of Law and Terrorism. HVG-Orac 2015. 
Tal, BECKER: Terrorism and the State: Rethinking the Rules of State Responsibility. Hart Publishing 2006.

Lawrence W., BEER: Constitutionalism and Rights in Japan and Korea. In: Constitutionalism and Rights (szerk. Louis, HeNKIn, Albert J., RosenthAL) 1990.

Aniel Caro, DE BEER: Peremptory Norms of General International Law (Jus Cogens) and the Prohibition if Terrorism. Koninklijke Brill NV, Leiden 2019.

Charles, BEITZ: Political equality. Princeton University Press 1989.

James E., Bell, Lynn A., STAEHELI: Discourses of diffusion and democratization. In: Political Geography 2001/2.

Orna Ben-NAfTALI, Karen R. MiKaELI: We must not make a scarecrow of the law: A legal analysis of the israeli policy of targeted killings. In: Cornell International Law Journal 2003/2.

Gregory, BERRY: Why Procedural Due Process is Essential to the Functioning of a Free Society. Howard university 2002.

Andrea, BIANCHI: Human Rights and the Magic of Jus Cogens. In: The European Journal of International Law 2008/3.

BIHARI Mihály: Politológia - A politika és a modern állam. Pártok és ideológiák. Nemzedékek Tudása Tankönyvkiadó 2013.

Gunn Elisabeth, BiRKelund, Tak Wing, CHAn, Elisabeth, UGREnInOV, Arnfinn H., MidTBøEN, Jon, RoGSTAD: Do terrorist attacks affect ethnic discrimination in the labour market? Evidence from two randomized field experiments. In: The British Journal of Sociology 2019/1.

Robert C., BLITT: How to Entrench a de facto State Church in Russia: A Guide in Progress. In: Brigham Young University Law Review 2008/3.

Hans, Born, Ian, LeIGH, Aiden, WiLlis (eds.): International Intelligence Cooperation and Accountability. Routledge, London, New York 2011.

Angela, BOURNE: The proscribtion of parties and the problem of 'militant democracy'. Journal of Comparative Law 2012/1.

Bérénice Boutin: Excesses of Counter-Terrorism and Constitutional Review in France: The Example of the Criminalisation of the Consultation of Websites. 2018. május 10.

Karl Dietrich, BRACHER, Manfred, FunKE, Hans-Adolf, JACOBSEN: Nationalsozialistische Diktatur 1933-1945. Eine Bilanz.

Jean-Paul, BreKKE, Simon Roland, BRIKVAD, Marta, BIVAND ERDAL: Losing the Right to Stay: Revocation of immigrant residence permits and citizenship in Norway - Experiences and effects. Report 2019:9. Institutt for Samfunnsforskning, Oslo 2019. 
BRUHÁCs János: A nemzetközi jog tegnap és ma. In: Állam- és Jogtudomány 2013/3-4.

Walter Bryce, GALLIE: Essentially contested concepts. Proceedings of the Aristotelian Society, 1956.

Daniel L., BYMAN: How terrorism undermines democracy. 2019.

Giovanni, CAPOCCIA: Defending Democracy: Reactions to Extremism in Interwar Europe. European Journal of Political Research 2001/4.

Astrid, CARrapatoso, Bernd, SchlipPHAK: Bringing the individual back in. International Relations and the First Image. European Consortium for Political Research Workshop.

Kaustav, ChAKRABARTI: Terrorism: Challanges to Politics, Society and International Relations. In: Jadavpur Journal of International Relations 2008/1.

Iain Christopher Edward, CHANNING: Blackshirts and White Wigs: Reflections on Public Order Law and the Political Activism of the British Union of Fascists. University of Plymouth Research Theses 2014.

CHRONOWSKI Nóra: Jogállamiság - Gondolatok a magyar és az európai uniós jogfejlődésről. In: Magyar Közigazgatás 2016/4.

John Alan, CoHAn: Necessity, Political Violence and Terrorism. In: Stetson Law Review $2006 / 3$.

Raphael, CoHEn-Almagor: The Boundaries of Liberty and Tolerance The Struggle against Kahanism in Israel. Gainesville: University Press of Florida 1994.

Raphael, Cohen-Almagor: Combating Right-Wing Political Extremism in Israel: Critical Appraisal. In: Terrorism and Political Violence 1997/4.

Darragh K., ConNell: Defending the Rule of Law in Challenging Times: A Legal and Philosophical Discourse 2010.

Anthony H., CORDESMAN: International Cooperation in Counterterrorism: Redefining the Threat and the Requirement. Center for Strategic and International Studies 2010.

Jon C., Cowen: The Omnibus Diplomatic Security and Antiterrorism Act of 1986: Faulty Drafting May Defeat Efforts to bring Terrorists to Justice. In: Cornell International Law Journal $1988 / 1$.

Neta C., Crawford: Just War and the U.S. Counterterror War. In: Perspectives on Politics. Cambridge University Press 2003/1.

Ronald D., Crelinsten, Alex P., Schmid: Western Responses to Terrorism: A Twenty Five Year Balance Sheet. In: Terrorism and Political Violence 1992/4.

William, CROTTY (ed.): The Politics of Terror. The U.S. Response to 9/11. Northeastern University Press 2004. 
CSINK Lóránt: Mikor legyen a jogrend különleges? In: Iustum Aequum Salutare 2017/4.

Robert, DAHL: On Democracy. Yale University Press 2000.

Jørgen DALBerg-LARSEN: Alf Ross and the Sociology of Law. Stockholm Institute for Scandinavian Law 2010

Ahmed AL-Dawoody: Non-International Armed Conflicts under Islamic Law: The Case of ISIS. In: Nuremberg Academy Series 2018/2.

Jan Delhey, Kenneth Newton: Predicting Cross-National Levels of Social Trust: Global Patterns of Nordic Exceptionalism. In: European Social Review 2005/4.

M., Delmas-Marty, De l'état d'urgence au despotisme doux. In: Libération, 16 july 2017.

Alan M., DeRshowitz: Why Terrorism Works? Understanding the Threat, Responding to the Challenge. Yale University Press, New Haven 2003.

David, Doherty, Jessica, MeCELLEM: Procedural and Substantive of Democracy in Four Arab Populations.

Laura K., DonOHUE: Transplantation. In: Global Anti-terrorism Law and Policy 2nd edition. (szerk.: Victor V., RAMraJ, Michael, Hor, Kent, ROACH, George, Williams). Cambridge University Press 2012.

John S., DRYZEK: Discursive Democracy. Cambridge University Press, Cambridge 1994.

Olivier, DuHAMEL: Terrorism and Constitutional Amendment in France. In: European Constitutional Law Review 2016/1.

Ronald, Dworkin: Terror \& the Attack on Civil Liberties. The New York Review of Books. 2003. november 6 .

Stephen, Dyson: Cognitive Style and foreign policy. In International Political Science Review 2009/1.

Steve, FARKAS, Jean, Johnson, Ann, DufFetT, Kathleen, Collins: Aggrevating Circumstances. A Status Report on Rudness in America. A report from Public Agenda 2002.

Thomas, FLEINER-GERSTER: Az állam és a társadalom céljai és feladatai. In: Államtan - Írások a XX. századi államtudomány köréböl (ford.: TAKÁCs Péter), Szent István Társulat, Budapest 2003.

Gregory H., Fox, Georg, NolTE: Intolerant Democracies. In: Harvard International Law Journal 1995/1.

Thomas Martin, FRANCK: The Emerging Right to Democratic Governance. In: The American Journal of International Law 1992/1. 
FRIVALDSZKY János: A közjó Aquinói Szent Tamásnál és a neotomista természetjogi gondolkodásban. In: Iustum Aequum Salutare. 2013/4.

Francis, FuKUYAMA: The End of History? In: The National Interest 1989/16.

Francis, FuKUYAMA: The End of History and the Last Man, Free Press 1992.

Tom GAL: Legal Classification of the Conflict(s) in Syria. In: The Syrian War. Between Justice and Political Reality. (eds.) Hilly Moodrick-Even KHEN, Nir T. BOMS, Sareta AsHraPH. Cambridge University Press 2020.

Sophie, GASTON: Mapping and responding to the rising culture and politics of fear in the European Union. Nothing to fear but Fear itself? Demos, London 2017.

Gerd, GigerenZer: Dread Risk, September 11, and Fatal Traffic Accidents. In: Psychological Science 2004/4.

Terry D. GILL: Classifying the Conflict in Syria. In: International Law Studies 2016/1.

Mary Ann, Glendon, Michael Wallace, Gordon, Christopher, OsAKwE: Comparative Legal Traditions. Text, Materials and Cases. West Publishing Company, St. Paul, Minnesota

Alan, GREENE: Defining Terrorism: One size fits all? In: International and Comparative Law Quarterly. 66. évfolyam 2. szám Cambridge Univeristy 2017.

Oren, Gross: Are Torture Warrants Warranted? Pragmatic Absolutism and Official Disobedience. University of Minnesota Law School, Legal Studies Research Paper Series, Research Paper 2004/4-6.

Jürgen, HABERMAS: Theorie des kommunikativen Handelns 1981.

M. Shansul, HAQUE: Government Responses to Terrorism: Critical Views of their Impacts on People and Public Amdinistration. In: Public Amdinistration Review. Különszám: Democratic Governance in the Aftermath of September 112001.

Toby, HARRIS: An independent review of London's preparedness to respond to a major terrorist incident 2016.

Richard, HARTSHORnE: Political Geography in the Modern World. In: The Journal of Conflict Resolution, Vol.4 No.1, The Geography of Conflict 1960.

Anders, HENRIKSEN: A small contribution on the rule of law and and anti-terrorism 2010.

Peter, HeRVIK: The Danish Muhammad Cartoon Conflict. Current Themes in IMER Research Number 13. Malmö University 2012.

Bruce, Hoffman, William, Rosenau, Andrew J., Curiel, Doron, Zimmermann: The Radicalisation of Diasporas and Terrorism. A Joint Conference by the RAND Corporation and the Center for Security Studies, ETH Zürich. RAND 2007. 
HofFMANN Tamás: Az emberiesség elleni büncselekmények nemzetközi és magyar jogi szabályozása. In: Állam- és Jogtudomány 2017/1.

Nasser, HuSSAIN: The Jurisprudence of Emergency: Colonialism and the Rule of Law. Univeristy of Michigan Press 2003.

Anne Michèle, IMOBERSTEG HARVEY: Terrorism: A type of organised crime or an offence sui generis? Similarities and differences in the Australian and European Union legislative approaches. PhD Thesis University of Western Australia 2013.

Samuel, IsSACHAROFF: Fragile Democracies. In: Harvard Law Review 2007.

JAKAB András: A jogállamiság mérése indexek segitségével. In: Pázmány Law Working Papers 2015/12.

JAKAB András - TiLl Szabolcs: A különleges jogrend. In: TRÓcsÁNYI László - SCHANDA Balázs (szerk.): Bevezetés az alkotmányjogba. HVG-Orac, Budapest 2013.

Kenneth, JANDA, Jeffrey M., BerRy, Jerry, Goldman, Deborah, SHILDKRAuT: The Challenge of Democracy. American Government in Global Politics. Twelfth Edition. Cengage Learningm 2013.

Mary Henrietta, KALDOR: Democracy and globalisation. In: Working paper series. Centre for the Study of Global Governance, London School of Economics and Political Science, London, UK $2008 / 3$.

Zdeněk, Kalvach: Basics of soft targets protection. Guidlines. Soft Targets Protection Institute. Prága 2016.

KARDOS Gábor: A szolidaritás határai. In: Liget: Irodalmi és ökológiai folyóirat 2008/3.

KARDOS Gábor: Carl Schmitt és az államközi konfliktusok kérdése. In: Iustum Aequum Salutare 2012/1.

KARDOS Gábor: Az államok szuverén egyenlösége. In: Jakab András - Fekete Balázs (szerk.) Internetes Jogtudományi Enciklopédia. Nemzetközi jogi rovat (rovatszerkesztő: Sulyok Gábor) 2018.

Christian, KAUNERT, Sarah, LÉONARD: The collective securitisation of Terrorism in the European Union. In: West European Politics 2018/2.

Henry, Kissinger: Diplomácia. Panem Könyvkiadó 2007.

Daniel, KoEHLER: Understanding Deradicalization. Methods, tools and programs for countering violent extremism. Routledge 2016.

Friedrich, KOJA: Állami szükségállapot és a szükségállapotra vonatkozó jog. In: Államtan (szerk. TAKÁCs Péter) Szent István Társulat Budapest 2003. 
KOLTAY András: Az új média és szólásszabadság. A nyilvánosság alkotmányos alapjainak újragondolása. Wolters Kluwer, Budapest 2019.

Vaios Koutroulis: The Fight Against the Islamic State and Jus in bello. In: Leiden Journal of International Law 2016/3.

KÖRÖSÉNYI András: Carl Schmitt állam- és politikaelméleti alapfogalmai. In: Politikatudományi Szemle 2000/3-4.

David KRETZMER: Targeted Killing of Suspected Terrorists: Extra-Judicial Executions or Legitimate Means of Defence. In: European Journal of International Law. 2002/2.

Audrey, KURTH CRONIN: ISIS is not a terrorist group. In: Forreign Affairs. 2015 március/április.

Jan-Erik, LANE: The New Patterns of Warfare: Terrorism against Innocent Civilians. In: Contemporary Issues. 2010/1.

Todd, LiTMAn: Terrorism, Transit and Public Safety. Evaluating the Risks. Victoria Transport Policy Institute 2012. január 16.

Karl, LoewensteIn: Autocracy versus Democracy in Contemporary Europe I. In: The American Political Science Review 1935/4.

Karl, LoewensteIn: Autocracy versus Democracy in Contemporary Europe II. In: The American Political Science Review 1935/5.

Karl, LoewensteIn: Militant Democracy and Fundamental Rights I. In: American Political Science Review 1937/3.

Karl, LoewensteIn: Militant Democracy and Fundamental Rights II. In: American Political Science Review 1937/4.

Karl, LoEwENSTEIN: Legislative Control of Extremism in European Democracies. In: Columbia Law Review 1938/4.

Karl, LoEwensteIn: The Balance of Legislative and Executive Power: A Study in Comparative Constitutional Law. In: The University of Chicago Law Review 1938/4.

Karl, LoewensteIn: Constitutions and Constitutional Law in the West and in the East. In: The Indian Journal of Political Science. 1969/3.

Lennart, LUNDQVIST: Förvaltning och demokrati. Norstedts juridikförl (Lund: Studentlitteratur), 1991.

Patrick, MaCKLEM: Guarding the Perimeter: Militant Democracy and Religious Freedom in Europe. University of Toronto - Faculty of Law 2010.

Crawford Brough, MACPHERSON: Democratic theory: Essays in retrieval. Oxford University Press 1973. 
George, MARCus: How Fear and Anger Impact Democracy. In: Democracy Papaers Essay 2019.

Stephen A., Meserve, Daniel, Pemstein, William T., Bernhard: Political Ambition and the Legislative Behavior in the European Parlieament. In: The Journal of Politics. The University of Chicago Press 2009/3.

John Stuart, MiLl: Representative Government. 1861. Reprint: Batoche Books, Kitchener, Ontario, Canada 2001.

Kurt A., Moenle, Eugene E., LevitT: The History of the Concepts of Fear and Anxiety. In: Clinical Psychology. (szerk. C. E., WALKER) Applied Clinical Psychology. Springer, Boston 1991.

G., More: Undercover Surveillance of the Republikaner Party: Protecting a militant Democracy or Discrediting a Political Rival. In: German Politics 1994/2.

Hans J., Morgenthau: Politics Among Nations. The Struggle for Power and Peace. Hetedik Kiadás 2005

Ingo, Müller: Hitler's Justice. The Courts of the Third Reich. 1st Edition. Harvard University Press 1992.

Peter R., Neumann: Countering Violent Extremism and Radicalisation that Lead to Terrorism: Ideas, Recommendations, and Good Practices from the OSCE Region. (Report) 2017. szeptember 28 .

Tore, NyHAmar: A future Nordic alliance. Prerequisits and possible operations. Norwegian Defence Research Establishment. 2019.

Liav, ORGAD: The Preamble in Constitutional Interpretation. In: International Journal of Constitutional Law 2010/4.

Ami, Pedahzur: Struggling Challenges of Right-Wing Extremism and Terrorism within Democratic Boundries: A comparative Analysis. In: Studies in Conflict and Terroism 2001/5.

Antje, PEDAIN: Do headscarfs bite? In: Cambridge Law Journal 2004/3.

Alain, Pellett, Sarah, Pellett: From $a$ „Non-War’... in: Tilburg Foreign Law Review. Special Issue: The Aftermath of September 11. 2002/10.

Otto, Pfersmann: Shaping Militant Democracy: Legal Limits to Democratic Stability. In: SAJÓ, András (ed.) Militant Democracy 2004.

Ben, Plache: Soldiers for Democracy: Karl Loewenstein, John H. Herz, Militant Democracy and the Defense of the Democratic State. Virginia Commonwealth University 2013.

Raymond, PLANT: Jürgen Habermas and the idea of legitimation crisis. In: European Journal of Political Research. Elsevier Scientific Publishing Company, Amsterdam 1982/4. 
PINTÉR Róber (szerk.): Az információs társadalom. Az elmélettöl a politikai gyakorlatig. Gondolat - Új Mandátum, Budapest 2007.

John PodestA: USA Patriot Act: The Good, The Bad, and the Sunset. In: Human Rights 2002/1.

POKOL Béla: Politikaelmélet - Társadalomtudományi trilógia III. Századvég Budapest 2006.

Christy Garce, PROVINES: Understanding Radicalization Through the Lens of 'Identity Vulnerability'. In: Columbia Journal of International Affairs 2017.

John, RAWLS: A Theory of Justice. Harvard University Press, Cambridge, Massachusetts 1980.

Kent, RoACH: Anti-Terrorism and Militant Democracy: Some Western and Eastern Responses. In: SAJÓ, András (ed.) Militant Democracy. Eleven International Publishing, Amsterdam 2004.

Bryan W., ROBERTS: The Macroeconomic Impacts of the 9/11 Attack: Evidence from Real-Time Forecasting. Working Paper, US Homeland Security 2009.

SAJÓ András: Önvédő jogállam. In: Fundamentum 2002/3-4.

Aurel, SARI: Blurred Lines: Hybrid Threats and the Politics of International Law. European Centre of Excellence for Countering Hybrid Threats 2018.

SÁGVÁRI Ádám: Különleges jogrend a francia jogban. Az állandósult kivételesség. In: Iustum Aequum Salutare 2017/4.

SCHANDA Balázs: Magyar állami egyházjog. Szent István Társulat, Budapest 2003.

SCHANDA Balázs: Globalizáció és nemzeti identitás. In: (CSINK Lóránt, SCHANDA Balázs, szerk.) Összehasonlító módszer az alkotmányjogban. Pázmány Press Budapest 2017.

Michael P., SCHARF: Special Tribunal for Lebanon Issues Landmark Ruling on Definition of Terrorism and Modes of Participation. In: American Society of International Law 2011/6.

Bernd, SchlipPHAK, Timo, MENIKKEN: Assessing attitudes towards regional integration processes. In: Philippe, De LombAERde, Renato, FLÔRES, Lelio, IADPADRE, Michael, SchUlZ: The Regional Integration Manual.Quantitative and Qualitative Methods. 1st Edition. Routledge 2012.

Alex P. SCHMID: Terrorism - The Definitional Problem. In: Case Western Reserve Journal of International Law 2004/2.

Alex. P., SCHMID: The Definition of Terrorism. In: The Routledge Handbook of Terrorism Research (ed.) Alex P. SCHMID. Routledge, London - New York 2011.

Carl, SchmitT: Az állami és politikai. A politika fogalma (1927). A birodalmi elnök mint az alkotmány öre. In: Államtan. Írások a XX. századi általános államtudomány köréböl. Szerk.: TAKÁCS Péter. Szent István Társulat 2003. 
Joseph, SCHUMPETER: Capitalism, Socialism and Democracy. Allen \& Unwin, London 1952.

Robert William, SHOEMAKER: „Democracy” and „Republic” as Understood in Late Eighteenth-Century America. In: American Speech 1966/2.

James. C., SIMEON: The Evolving Common Law Jurisprudence Combatting the Threat of Terrorism in the United Kingdom, United States and Canada. In: MDPI Laws 2019/5.

SIMICSKÓ István: A terrorizmus elleni védelem fokozása a különleges jogrendi kategóriák bövitésével. In: Hadtudomány 2016/3-4.

Amanda, SKULDT: Terrorism and Foreign Policy. International Studies. Oxford University Press 2010.

Gordon, Smith: Die Institution der politischen Partei in Großbritannien. In: Parteienrecht im europäischen Vergleich (szerk. Dimitris, TSATSOS) 1990.

SONNEVEND Pál, JAKAB András, CSINK Lóránt: The Constitution as an Instrument of Everyday Party Politics: The Basic Law of Hungary. In: Constitutional Crisis in the European Constitutional Area. Theory, Law and Politics in Hungary and Romania. (ed. Armin, VON BogdAnDy, Pál, SonNEVEND,) C.H.Beck-Hart-Nomos 2015.

Holger, Stritzel: Security as a translation: Threats, Discourse, and the Politics of Localisation. In: Review of International Studies. Cambridge University Press 2011/5.

Sofie G. SyeD: Sovereign Immunity and Jus Cogens: Is There a Terrorism Exception for Conduct-Based Immunity? In: Columbia Journal of Law and Social Problems 2016/2.

SZABÓ István: Különleges jogrend a weimari alkotmányban. A fogalmak pontossága - a jogalkalmazó mérlegelési lehetösége. In: Iustum Aequum Salutare 2017/4.

SzABÓ Miklós: A jogforrás. In: SzABÓ Miklós (szerk.) Bevezetés az jog- és államtudományokba. Bíbor Kiadó, Miskolc 2001.

SZATHMÁRY Béla: Az állam és az egyházak elválasztott müködése a gyakorlatban Magyarországon. (Habilitációs eljárás tézisei) Debreceni Egyetem Állam- és jogtudományi Doktori Iskola. Debrecen 2010.

SzIJÁRTÓ Lívia: Alkalmazott pszichológiai módszerek a terrorizmus elleni harcban. Doktori értekezés 2018.

SZILÁGYi Péter: Jogalkotás, törvényhozás, kódex. In: Jogi alaptan (szerk. SzILÁGYi Péter). Osiris 2001.

SzIGETI Péter, TAKÁCs Péter: A jogállamiság jogelmélete. Napvilág Kiadó, Budapest. Második kiadás 2004.

SzUHAi Ilona, TÁLAS Péter: A 2015-ös migrációs és menekültválság okairól és hátteréröl. In: TÁLAS Péter (szerk.) Magyarország és a 2015-ös európai migrációs válság. Dialóg Campus, Budapest 2017. 
TAMÁS András: Legistica. A jogalkotástan vázlata. Szent István Társulat, Budapest 2005.

TÁLAS Péter (szerk.): A terrorizmus anatómiája. Zrínyi Kiadó, Budapest 2006.

TÁLAS Péter: A terrorveszélyhelyzet-diskurzus margójára. In: Nemzet és biztonság 2016/1.

TÁlAS Péter: A nemzetközi hatalmi viszonyok változása, geopolitikai következmények. In: FINSZTER Géza, SABJANICS István (szerk.) Biztonsági kihívások a 21. században. DialógCampus, Budapest 2017.

Tо́тH Árpád: A kivételes hatalom jogi szabályozása Magyarországon az első világháború elöestéjén. JATE ÁJK tudományos bizottsága, Szeged 1996.

Laurence H., TRIBE: Trial by Fury. In: The New Republic. 2001. november 29.

Jamie, TRINIDAD: An Evaluation of Morocco's Claims to Spain's Remaining Territories in Africa. In: The International and Comparative Law Quarterly. 2012/4.

TRÓCSÁNYi László, SCHANDA Balázs (szerk.): Bevezetés az alkotmányjogba. Az Alaptörvény és Magyarország alkotmányos intézményei. HVG-Orac Lap- és Könyvkiadó Kft. 2014.

Svetlana, TyULKINA: Militant Democracy. Central European University, 2011.

Dominique, VAnNeste, Petronella, Tudorache, Flavia, TeOdoroiU, Thérése, STEENBERGHEN: The impact of the 2016 terrorist attacks in Brussels on tourism. In: Belgeo $2017 / 4$.

VASS György: A terrorizmus finanszírozása elleni küzdelem nemzetközi aspektusai. Doktori értekezés 2017.

VARgA Zs. András: Alkotmányunk értékei. A fogalmi keretek. In: Iustum Aequum Salutare. 2009/1.

VArga Zs. András: A mag-alkotmány védelmében. In: Pázmány Law Working Papers 2011/2.

VARGA Zs. András: Eszményből bálvány? Századvég Budapest 2015.

VARGA Zs. András: A közigazgatás és a közigazgatási jog alkotmányos alapjai. DialógCampus, Budapest 2017.

VARGA Zs. András: A közigazgatás jogvédelmi rendszere. In: JAKAB András, FeKETE Balázs (szerk.) Internetes jogtudományi enciklopédia. (Közigazgatási jog rovat. rovatszerkesztő BALÁZS István) 2017 [57]

Viljar, VeEBel, Illimar, PloOM: Estonia's comprehensive approach to national defence: origins and dilemmas. In: Journal on Baltic Security 2018/2.

Clive, WALKER: Intelligence and Anti-Terrorism Legislation in the United Kingdom. In: Criminal Law \& Society Change 2005/4-5. 
Clive, WALKeR: Know Thine Enemy as Thyself: Discerning Friend from Foe under AntiTerrorism Laws, 32 Melbourne University Law Review 2008/3.

Clive, WALKER: The Threat of Terrorism and the Fate of Control Orders. In: Public Law 2010.

Clive, WalkeR: Militant Speech About Terrorism in a Smart Militant Democracy. In: Mississippi Law Journal 2011/4.

Clive, WALKER: Terrorism and the Law. Oxford University Press, Oxford. 2011.

Clive, WALKeR: Human Rights and Counterterrorism in the UK. Az ENSZ Emberi Jogi Főbiztossága számára készített tanulmány 2016.

Stephen M., WALT: „Empathy” and international affairs. In: Foreign Policy. 2009. május 27.

Annemarie, VAN DE WEERT, Quirin A. M., EIJKMAN: Subjectivity in detection of radicalisation and violent extremism: a youth worker's perspective. In: Behavioral Sciences of Terrorism and Political Aggression 2019/3.

Theodor H., Winkler, Anja H., EBnÖTHER, Mats B., HANSON (eds.): Combating Terrorism and Its Implications For the Security Sector. Swedish National Defence College, Stockholm, Geneva Centre for the Democratic Control of Armed Forces, Geneva in the framework of the Partnership for Peace Consortium of Defence Academics and Security Studies Institutes, Elanders Gotab, Vällingby 2005.

Nargis, ZAHRA: Terrorism, Realism and the State. In: Pakistan Horizon 2011/1.

Kirill, ZhiRKov, Maykel, VerkUYTen, Jeroen, WeEsie: Perceptions of world politics and support for terrorism among Muslims: Evidence from Muslim countires and Western Europe. In: Conflict Management and Peace Science 2014/5. 
Hivatkozott jogforrások

-Nemzetközi jogforrások:

Charter of the International Military Tribunal For the Far East címü proklamáció, 1946.

ENSZ BT 2253-as határozat

Emberi Jogok Európai Nyilatkozata

A FÁK országok által a terrorizmus elleni küzdelemben való együttmüködésről szóló 1999-es egyezmény

A terrorizmus finanszírozásának visszaszorításáról, New Yorkban az Egyesült Nemzetek Közgyülésének 54. ülésszakán, 1999. december 9-én elfogadott nemzetközi egyezmény

-Európai Uniós jogforrások:

Az Európai Unióról szóló Szerződés

Az Európai Unió Működéséről szóló Szerződés

A terrorizmus elleni küzdelemről szóló 2002. június 13-án kiadott 2002/475/JHA számú Tanácsi kerethatározat

-Magyar jogforrások:

Magyarország Alaptörvénye

2005. évi CXXXIII. törvény a személy- és vagyonvédelmi, valamint magánnyomozói tevékenység szabályairól

2012. évi C. törvény a Büntető Törvénykönyvről

2015. évi CXL. törvény az egyes törvényeknek a tömeges bevándorlás kezelésével összefüggő módosításáról

-Külföldi jogforrások:

(Egyesült Királyság)

Human Rights Act of 1998

Prevention of Terrorism Act of 2005

Terrorism Act of 2006

Justice and Security (Northern Ireland) Act of 2007

Counter-Terrorism Act of 2008

Coroners and Justice Act of 2009

Justice and Security Act of 2013

Counter-Terrorism and Security Act of 2015

(Franciaország)

Franciaország Alkotmánya

Loi n ${ }^{\circ} 55-385$ du 3 avril 1955 relative à l'état d'urgence

Loi $\mathrm{n}^{\circ}$ 2017-1510 du 30 octobre 2017 renforçant la sécurité intérieure et la lutte contre le terrorisme

Code de procédure pénale 


\section{$\underline{\text { Hivatkozott jogesetek }}$}

Lawless v. Írország, 332/57 (ECHR)

Írország v. Egyesült Királyság, 5310/71. (ECHR)

McCann és Társai v. Egyesült Királyság, 18984/91. (ECHR)

A Refah Partisi és Mások v. Törökország, 41340/98, 41342/98 és 41343/98 (ECHR)

Leyla Şahin v. Törökország ügye, 44774/98. (ECHR)

A. és mások v. Egyesült Királyság 3455/05. (ECHR)

Vajnai v. Magyarország 33629/06 (ECHR)

Quardiri v. Svájc 65840/09. (ECHR)

Public Committee Against Torture v. Government (HCJ 769/02)

Ligue des Musulmans de Suisse és Mások v. Svájc 66274/09. (ECHR)

BB, PP, W, U and Others and Secretary of State for the Home Department Royal Courts of Justice 2015. január 23.

Tribunal Administratif de Nice 1603508 és 1603523 számú döntései

Conseil Constitutionnel 2016-611 QPC 


\section{Egyéb hivatkozott források}

Secretary of State for Nothern Ireland, Report of the Commission to Consider Legal Procedures to Deal with Terrorist Activites in Northern Ireland, 1972.

Report of the Events Relating to Maher Arar. Commission of Inquiry into the Actions of Canadian Officials in Relation to Maher Arar. Her Majesty the Queen in Right of Canada represented by the Minister of Public Works and Government Services, Ottawa, Canada 2006

The Impact of Terrorism on State Law Enforcement. Adjusting to New Roles and Changing Conditions. Final Report 2006. The Council of State Governments, Eastern Kentucky Univeristy

Arab Barometer Survey (2006-2008)

Human Rights, Terrorism and Counter-Terrorism. Fact Sheet No. 32. Office of the United Nations High Commissioner for Human Rights. 2008

Ministry of Defence, United Kingdom: The Aitken Report: an investigation into cases of deliberate abuse and unlawful killing in Iraq in 2003 and 2004. Westminster, London, 2008

House of Lords, House of Commons Joint Committee on Human Rights: UN Convention Against Torture: Discrepancies in Evidence Given to the Committee About the Use of Prohibited Interrogation Techniques in Iraq. Twnety-eighth Report of Session 2007-08. Westminster, London, 2008

Radicalisation, Recruitment and the EU Counter-Radicalisation Strategy. In: Transnational Terrorism, Security and the Rule of Law. 2008. november 17.

Baha Mousa Public Inquiry report, 2011

A Nemzeti Adatvédelmi és Információszabadság Hatóság ajánlása a különleges jogrend szabályozásának információs alapjogi kereteiről. NAIH20160128AJ-NL-S

A Velencei Bizottságnak a Nemzet védelméről szóló francia törvénytervezetre adott véleménye. 838/2016. sz. vélemény. 2016. március 11-12.

Combatting Islamist Terrorism and Protecting our Way of Life. Resolution adopted by the EPP Political Assembly, Brussels 4th-5th December 2017

Status of the Universal Anti-Terrorism Conventions and Protocols as well as other International and Regional Legal Instruments related to Terrorism and Co-operation in Criminal Matters in the OSCE Area. 2018 július

The protection of critical infrastructures against terrorist attacks: Compendium of good practices. UNOCT, CTED, Interpol, 2018.

First report of the observatory function on encryption. Europol EC3 European Cybercrime Centre, Hága 2019. január 11. 
DOI: 10.15774/PPKE.JAK.2020.007

Eurostat Panorama on Tourism

Eurostat Year Book Transport 
$\underline{\text { Internetes hivatkozások }}$

https://www.echr.coe.int/Documents/FS_Terrorism_ENG.pdf.

https://www.justsecurity.org/63499/how-news-media-talk-about-terrorism-what-the-evidenceshows/

https://georgewbush-whitehouse.archives.gov/news/releases/2001/09/20010916-2.html]

https://www.counterpunch.org/2002/09/07/the-tenth-crusade/

https://www.govtrack.us/congress/bills/statistics

https://ec.europa.eu/home-affairs/what-we-do/networks/radicalisation_awareness_network_en

https://www.gouvernement.fr/en/the-fight-against-jihadism-is-the-great-challenge-of-ourgeneration

https://www.fatf-gafi.org/media/fatf/documents/reports/Guidance-Criminalising-TerroristFinancing.pdf

https://www.regeringen.se/49344e/contentassets/99eddffed5754ec483fd385d6c397a03/ettsarskilt-straffansvar-for-deltagande-i-en-terroristorganisation.pdf

https://www.thelocal.fr/20161111/what-happened-in-france-after-the-paris-terror-attacks

https://www.express.co.uk/news/uk/620616/New-Paris-terror-WARNING-British-schoolsordered-to-BAN-school-trips-to-France

http://www.naih.hu/files/NAIH-2019-55_hatarozat.pdf

https://www.diplomatie.gouv.fr/en/french-foreign-policy/security-disarmament-and-nonproliferation/france-s-international-action-against-terrorism/

https://www.government.nl/topics/counterterrorism-and-national-security/counterterrorism)

https://www.verfassungsschutz.de/de/das-bfv/akademie-fuer-verfassungsschutz/pbdiplomarbeiten

https://www.publicagenda.org/files/aggravating_circumstances.pdf

http://www.eurojust.europa.eu/press/PressReleases/Pages/2019/2019-09-05.aspx

https://www.parliament.uk/about/living-

heritage/evolutionofparliament/originsofparliament/birthofparliament/overview/magnacarta/m agnacartaclauses/

https://verfassungsblog.de/state-secrecy-in-counterterrorism-different-judicial-standards-ofreview-the-abu-omar-case-before-italian-courts/

http://hudoc.echr.coe.int/fre?i=001-110887 
https://www.nytimes.com/2019/08/11/us/politics/domestic-terrorism.html

https://theintercept.com/2019/03/23/ecoterrorism-fbi-animal-rights/

https://www.consilium.europa.eu/en/policies/fight-against-terrorism/eu-strategy/

https://foreignpolicy.com/2018/11/23/want-to-deradicalize-terrorists-treat-them-likeeveryone-else-counterterrorism-deradicalization-france-sri-lanka-pontourny-cve/

http://opac.oireachtas.ie/AWData/Library3/smithwickFinal03122013 171046.pdf

https://cain.ulster.ac.uk/issues/collusion/cory/cory03wright.pdf

https://cain.ulster.ac.uk/issues/collusion/cory/cory03hamill.pdf

https://web.archive.org/web/20070108152316/http://www.nio.gov.uk/cory_collusion_inquiry report \%28without appendices $\% 29$ rosemary nelson.pdf

https://web.archive.org/web/20070108152519/http://www.nio.gov.uk/cory_collusion_inquiry report_\%28with_appendices $\% 29$ pat_finucane.pdf

https://assets.publishing.service.gov.uk/government/uploads/system/uploads/attachment data/ file/246867/0802.pdf

http://www.worldcourts.com/stl/eng/decisions/2011.02.16_Prosecutor_v_Ayyash.pdf

https://www.gouvernement.fr/sites/default/files/document/document/2018/09/rapport_de_mm e alice thourot et m. jean-michel fauvergue deputes -

dun_continuum_de_securite_vers_une_securite_globale_-11.09.2018.pdf

https://assets.publishing.service.gov.uk/government/uploads/system/uploads/attachment_data/ file/378449/09-05-UK-Police-Requireme22835.pdf

https://www.google.com/url?sa=t\&rct=j\&q=\&esrc=s\&source=web\&cd=29\&ved=2ahUKEwi knYLboMnkAhXplYsKHVQ1B-

YQFjAcegQIRhAC\&url=http\%3A\%2F\%2Fwww.sustainablecities.eu\%2Ffileadmin $\% 2$ Ftemp lates $\% 2 \mathrm{Fesc} \% 2 \mathrm{Flib} \% 2 \mathrm{Ftransformative}$ actions $\% 2 \mathrm{~F} \% 2 \mathrm{~F}$ utility $\% 2 \mathrm{Ftools} \% 2 \mathrm{Fpush}$ resource file.php\%3Fuid\%3Ddd9bf772\&usg=AOvVaw1_jwT7LxdCgqppTKW-_jNU

https://www.vox.com/energy-and-environment/2019/4/8/18273893/barcelona-spain-urbanplanning-cars

https://www.g4s.com/en-us/-

/media/g4s/usa/files/whitepapers/vehicular_terrorism_the threat_behind_the_wheel.ashx

https://www.dhs.gov/sites/default/files/publications/privacy-matrix-122006.pdf

https://www.aclu.org/other/how-usa-patriot-act-redefines-domestic-terrorism 
http://www.assemblee-nationale.fr/14/pdf/ta/ta0735.pdf

https://www.conseil-constitutionnel.fr/decision/2017/2016611QPC.htm

http://www.assemblee-nationale.fr/14/pdf/ta/ta0915.pdf

https://www.conseil-constitutionnel.fr/decision/2017/2017682QPC.htm

http://marseille.cour-administrative-

appel.fr/content/download/104768/1049245/version/1/file/17MA01337\%20arrêt.pdf

https://www.theguardian.com/world/2017/mar/04/nigeria-declined-uk-offer-to-rescue-chibokgirls

https://europa.eu/rapid/press-release IP-18-6705 en.htm

https://ec.europa.eu/trade/policy/countries-and-regions/countries/morocco/

https://georgewbush-

whitehouse.archives.gov/infocus/bushrecord/documents/Selected_Speeches_George_W_Bush .pdf

https://www.diplomatie.gouv.fr/en/french-foreign-policy/security-disarmament-and-nonproliferation/events/events-regarding-defence-and-security/article/speech-by-the-president-ofthe-republic-before-a-joint-session-of-parliament

https://www.legifrance.gouv.fr/affichLoiPubliee.do?idDocument=JORFDOLE000034990290 $\underline{\text { \&type }}=$ expose $\&$ legislature $=$

https://www.parlament.hu/irom40/10416/10416.pdf

https://www.oecd.org/eco/outlook/1935314.pdf

https://londonbridgeinquests.independent.gov.uk/wp-content/uploads/2019/08/Ruling-on-A2and-Determinations-2.8.19.pdf

https://www.publicagenda.org/files/aggravating_circumstances.pdf

https://www.telegraph.co.uk/news/worldnews/europe/france/11341295/French-police-chiefcommitted-suicide-after-Charlie-Hebdo-attack.html

https://www.nytimes.com/1973/07/17/archives/karl-loewenstein-amherst-professor.html

http://www.legislation.gov.uk/id/ukpga/1936/6

https://www.spd.de/partei/personen/carlo-schmid/

https://www.counterpunch.org/2011/04/01/why-israel-is-not-a-democracy/

http://unesdoc.unesco.org/images/0024/002477/247764e.pdf 
http://www.gov.uk/government/publications/report-of-the-bloody-sunday-inquriy

http://www.uio.no/studier/emner/jus/jus/JUR5710/h10/undervisningsmateriale/13okt_In\%20t he $\% 20$ case $\% 20$ of $\% 20$ McCann $\% 20$ and $\% 20$ Others $\% 20$ v.pdf

https://www.independent.co.uk/news/uk/crime/seven-mistakes-that-cost-de-menezes-his-life1064466.html.

http://www.legislation.gov.uk/uksi/2004/751/pdfs/uksi_20040751_en.pdf https://www.legislation.gov.uk/ukpga/2007/6/pdfs/ukpga_20070006_en.pdf https://www.gpo.gov/fdsys/pkg/BILLS-107hr3162enr/pdf/BILLS-107hr3162enr.pdf http://i.a.cnn.net/cnn/2007/images/09/26/mayfield.patriotact.summary.judgment.pdf https://www.washingtonpost.com/news/post-politics/wp/2016/11/01/the-kks-officialnewspaper-has-endorsed-donald-trump-for-president/

http://multimedia.jp.dk/archive/00080/Avisside_Muhammed-te_80003a.pdf

http://www.dw-world.de/dw/article/0,2144,1839922,00.html

https://law.acri.org.i1/en/2016/07/19/update-mk-suspension-bill/

http://www.fetedeslumieres.lyon.fr/en/news/au-sujet-de-la-programmation-2016

https://www.coe.int/en/web/secretary-general/home//asset_publisher/oURUJmJo9jX9/content/france-informs-secretary-general-of-article-15derogation-of-the-european-convention-on-human-rights

https://www.cncdh.fr/sites/default/files/170706_avis_sur_le_pjl_securite_interieure_terrorism e.pdf

https://www.dalloz-actualite.fr/chronique/projet-de-loi-renforcant-lutte-contre-terrorisme-etsecurite-interieure-duplicite-du-presi\#.XF11uS35fdc

http://www.syndicat-magistrature.org/L-etat-d-urgence-contamine-le.html

https://www.hrw.org/news/2016/02/03/france-abuses-under-state-emergency

https://www.hrw.org/news/2016/02/22/dispatches-frances-renewed-emergency-law-recipeabuse

http://www.europarl.europa.eu/EPRS/EPRS-Briefing-581955-Radicalisation-genderperspective-rev-FINAL.pdf

https://2001-2009.state.gov/s/ct/c14151.htm 
https://www.diplomatie.gouv.fr/en/french-foreign-policy/security-disarmament-and-nonproliferation/france-s-international-action-against-terrorism/

https://www.conseil-etat.fr/actualites/discours-et-interventions/presentation-du-conseil-d-etat 


\section{A SZERZŐ TUDOMÁNYOS MUNKÁSSÁGA}

SABJANICS István: Fear as a Source of Threat with Legal Consequences. In: FInSZTER, G., SABJANICS I. (szerk.) Security challanges in the 21st century. Dialog Campus Kiadó, Budapest 2018., pp. 737-745.

BÉKÉSI Nikolett, SABJANICS István: A terrorizmus elleni fellépés magánszférát érintő kérdései. In: CsinK Lóránt (szerk.) A nemzetbiztonság kihívásainak hatása a magánszférára. Pázmány Press Budapest 2017., pp. 227-260.

CSINK Lóránt, SABJANICS István: A különleges jogrend alkotmányjogi és igazgatási értékelése. In: CsINK Lóránt (szerk.) A nemzetbiztonság kihívásainak hatása a magánszférára. Pázmány Press Budapest 2017., pp. 261-285.

SABJANICS István: Az Alkotmánybiróság határozata a bírák nemzetbiztonsági ellenőrzéséröl: A jogállamiság gyakorlati értelmezésének két konkuráló oldala. In: Jogesetek Magyarázata 2017/4., pp. 19-24.

SABJANICS István: A nemzetbiztonság jogi koncepciója. In: CsINK Lóránt (szerk.) A nemzetbiztonság kihívásainak hatása a magánszférára. Pázmány Press Budapest 2017., pp. 103123.

SABJANICS István: The Legality of National Security. In: Agnieszka BIEŃ-KACAŁA, CsinK Lóránt, Tomasz MiLEJ, Maciej SEROWANIEC (szerk.) Liberal constitutionalism - between individual and collective interests. Uniwersytet Mikołaja Kopernika w Toruniu, Torun 2017., pp. 221-236.

SABJANICS István: Ágazati-szakmai érdekek alakulása a különleges jogrendben: Különös tekintettel a nemzetbiztonsági szolgálatokra. In: Iustum Aequum Salutare 2017/4., pp. 91-103.

SABJANICS István: A rendészeti hatáskörök exportálása: A katonai és a rendvédelmi feladatok, avagy a tyúk és a tojás esete. In: CHRISTIÁN László (szerk.) Rendészettudományi kutatások: Az NKE Rendészetelméleti Kutatóműhely tanulmánykötete. Dialóg Campus Kiadó, Budapest 2017., pp. 121-128. 
SABJANICS István: A félelem mint jogi következményekkel járó veszélyforrás. In: FINSZTER G., SABJANICS I. (szerk.) Biztonsági kihívások a 21. században. Dialóg Campus Kiadó, Budapest 2017., pp. 745-753.

DRINÓCZI Tímea, CSINK Lóránt, SABJANICS István: A biztonság alkotmányjogi szabályozása Magyarországon. In: Agnieszka BIEŃ-KACAŁA, Jiři JiRÁSEK, Lubor CiBULKA, Tímea DRINÓCZI (szerk.) Kategorija bezpieczeństwa w regulacjah konsytucyjnych i praktyce ustrojowej państw Grupy Wyszehradzkiej. Wydawnictwo Naukowe Uniwersytetu Mikolaja Kopernika, Torun 2016., pp. 309-356.

Tímea DRINÓCZI, Lóránt CsINK, István SABJANICS: Chapter VI. Hungarian constitutional law and interprestations of security. In: Agnieszka BIEŃ-KACAŁA, Jiři JiRÁSEK, Lubor CiBULKA, Tímea DRINÓCZI (szerk.) Security in V4 constitutions and political practices. Wydawnictwo Naukowe Uniwersytetu Mikolaja Kopernika, Torun 2016., pp. 177-199.

SABJANICS István: A párizsi terrortámadással kapcsolatos jogi következtetések. In: Szakmai Szemle 2015/4., pp. 156-167.

SABJANICS István: Szerepváltozások a jogállamiság horizontján: A bíró szerepének felértékelödése. In: Szakmai Szemle 2015/2., pp. 163-174.

SABJANICS István: Minősitett időszakok az Alaptörvényen innen és azon túl. In: KovÁCs Péter (szerk.) Religio et Constitutio. Pázmány Press Budapest 2014., pp. 221-232.

SABJANICS István: Összehasonlitó elemzés a vallásszabályozás kérdéskörében európai kitekinteéssel, különösen a vallásgyakorlás színhelyére vonatkozó kötelezö állami elöirásokra. In: KovÁCs Péter (szerk.) Religio et Constitutio. Pázmány Press Budapest 2014., pp. 99-103.

SABJANICS István: Adatvédelem és terrorellenes intézkedések az Egyesült Államokban: A MATRIX modellkisérlet története és visszhangjai. In: GERENCSÉR Balázs Szabolcs (szerk.) Modellkísérletek a közigazgatás fejlesztésében: Az ún. ,pilot projektek” határai elméletben és gyakorlatban. Pázmány Press Budapest 2013., pp. 79-88. 
SABJANICS István: Az ügyészek büntetőjogon kívüli feladatai a Brit-szigeteken. In: VARGA Zs. András, PINTÉR Zsuzsanna (szerk.) Az ügyészek büntetőjogon kívüli tevékenysége. Pázmány Press Budapest 2013., pp. 137-142.

SABJANICS István: Elméleti alapvetések a különleges jogrend vonatkozásában. In: Magyar Rendészet 2013/2., pp. 69-80.

SABJANICS István: A terrorizmussal összefüggö jogalkotás kihívásairól. Magyar Rendészet 2012/Különszám, pp. 136-142.

SABJANICS István: Review on some actual legal issues regarding anti-terrorism legislation. In: Tradecraft Review 2012/1., pp. 212-218.

SABJANICS István: A terrorizmus jelentette jogállami kihívásokról. In: Új Magyar Közigazgatás 2011/6-7., pp. 67-71. 